$$
\text { UNIVERSIDADE DE SÃO PAULO }
$$

FACULDADE DE MEDICINA DE RIBEIRÃO PRETO

PÓS-GRADUAÇÃO EM IMUNOLOGIA BÁSICA E APLICADA

\author{
PAULO JOSÉ BASSO
}

Avaliação dos efeitos imunomoduladores de estatinas e glicocorticoides na terapêutica da colite experimental

Ribeirão Preto - SP 


\title{
Avaliação dos efeitos imunomoduladores de estatinas e glicocorticoides na terapêutica da colite experimental
}

\author{
Dissertação apresentada ao curso de Pós-graduação em \\ Imunologia Básica e Aplicada da Faculdade de Medicina \\ de Ribeirão Preto, Universidade de São Paulo, para a \\ obtenção do grau de Mestre em Ciências - Área de \\ concentração: Imunologia Básica e Aplicada.
}

Orientação: Prof a . Drª . Cristina Ribeiro de Barros Cardoso

\section{Versão Corrigida}

A versão original encontra-se disponível tanto na Secretaria da Pós-Graduação em Imunologia Básica e Aplicada, quanto na Biblioteca Digital de Teses e Dissertações da USP

Ribeirão Preto - SP 
AUTORIZO A REPRODUÇÃO E DIVULGAÇÃO TOTAL OU PARCIAL DESTE TRABALHO, POR QUALQUER MEIO CONVENCIONAL OU ELETRÔNICO, PARA FINS DE ESTUDO E PEQUISA, DESDE QUE CITADA A FONTE.

Catalogação da publicação

Faculdade de Medicina de Ribeirão Preto

Universidade de São Paulo

Basso, Paulo José

Avaliação dos efeitos imunomoduladores de estatinas e glicocorticoides na terapêutica da colite experimental. Ribeirão Preto, 2015.

156 f.: II.; $30 \mathrm{~cm}$

Dissertação de mestrado apresentada ao Programa de Pós-Graduação em Imunologia Básica e Aplicada da Faculdade de Medicina de Ribeirão Preto, Universidade de São Paulo. Área de concentração: Imunologia.

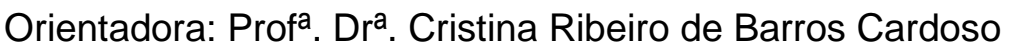

Palavras-chave: 1. Doença inflamatória intestinal; 2. Inflamação; 3. Tratamento. 
Nome: Paulo José Basso

Título: Avaliação dos efeitos imunomoduladores de estatinas e glicocorticoides na terapêutica da colite experimental

Dissertação apresentada ao curso de Pósgraduação em Imunologia Básica e Aplicada da Faculdade de Medicina de Ribeirão Preto, Universidade de São Paulo, para a obtenção do grau de Mestre em Ciências - Área de concentração: Imunologia Básica e Aplicada.

Aprovado em:

Banca Examinadora

Prof ${ }^{a}$. Drª . Cristina Ribeiro de Barros Cardoso Instituição: FCFRP/USP Julgamento: Assinatura:

Prof. Dr. Alexandre Salgado Basso Instituição: EPM/UNIFESP Julgamento: Assinatura:

Prof. Dr. José Joaquim Ribeiro da Rocha Instituição: FMRP/USP Julgamento: Assinatura: 
Trabalho realizado no Laboratório de Imunoendocrinologia e Regulação (LIR) do Departamento de Análises Clínicas, Toxicológicas e Bromatológicas (DACTB) da Faculdade de Ciências Farmacêuticas de Ribeirão Preto da Universidade de São Paulo (FCFRP/USP), com auxílio financeiro da Fundação de Amparo à Pesquisa do Estado de São Paulo (FAPESP; processos n²013/11042-6 e n²010/20162-7), da Coordenação de Aperfeiçoamentos de Pessoal de Nível Superior (CAPES), do Conselho Nacional de Desenvolvimento Científico e Tecnológico (CNPq), da Fundação de Apoio ao Ensino, Pesquisa e Assistência do Hospital das Clínicas da Faculdade de Medicina de Ribeirão Preto da Universidade de São Paulo (FAEPA) e do Núcleo de Apoio à Pesquisa em Doenças Inflamatórias (NAP-DIN). 
Dedico este trabalho primeiramente a Deus que, por Sua misericórdia infinita, me abençoa diariamente e nunca me desampara. Aos meus pais Vicente e Sueli, testemunhas vivas da mínha dedicação e empenho, pelo eterno e ímensurável amor, pela capacídade de me enxergar além do que os olhos veem e pelos precisos cuidados voltados para mínha formação profissional e moral. Aos meus írmãos Luis Gustavo e Mariane e ao meu cunhado Tíago pela confiança incorruptível, pelo incentivo e pelo carinho proporcionados durante toda a minha jornada. À minha namorada Daníela pelo amor, pelo apoío, pela cumplicidade integra, por me fazer acreditar que sou capaz de superar os obstáculos, por estar ao meu lado em todos os momentos e por ser meu refúgio verdadeíro e leal. Aos anjos que contribuíram diretamente ao longo desta jornada para minha formação acadêmíca e humana: Vó Madalena (ín memoríam), Reinaldo, Cássía, Gustavo, Fabiano, Padre Gustavo, Tia María, Tio Arvico, Zé, Di, Márcía, Kimí, Isabela, Fabinho, Ton e Viví.

A todos os meus demais familiares e amigos... 


\section{Agradecimentos}

Agradeço a Deus pelo seu eterno amor e por sempre ter me confortado com a graça da fé. Agradeço por me fazer refletir diariamente que os maiores ensinamentos se aprendem com as próprias experiências e que os erros e as críticas são essenciais para o progresso.

À Prof ${ }^{a}$. Dr ${ }^{a}$. Cristina Ribeiro de Barros Cardoso pela singularidade em sua orientação profissional e ética, pela educação científica, pela confiança depositada e pelo acolhimento em seu laboratório de pesquisa. Agradeço por me fazer perseverar na ciência, além de sempre me motivar a aproveitar e criar as oportunidades para o sucesso.

Ao Prof. Dr. Auro Nomizo, que além de colaborar com este trabalho por meio de seus conhecimentos ímpares, também foi um grande amigo, confidente e conselheiro. Agradeço por sempre ter confiado no meu potencial e por ter participado em todas as etapas da minha carreira científica, desde o início do meu curso de graduação.

Aos professores que compõem a banca examinadora desta defesa de dissertação, Prof. Dr. Alexandre Salgado Basso (EPM/UNIFESP) e Prof. Dr. José Joaquim Ribeiro da Rocha (FMRP/USP) pela disponibilidade, solicitude, sugestões e correções.

À Faculdade de Medicina de Ribeirão Preto (FMRP/USP) por ter me proporcionado o mais alto nível do conhecimento e diversas oportunidades para a progressão na carreira.

À Faculdade de Ciências Farmacêuticas (FCFRP/USP) que, além de ter sido o berço da minha educação, forneceu a estrutura e apoio necessários para o desenvolvimento deste projeto de pesquisa.

À Ana Cristine, secretária do Programa de Pós-graduação em Imunologia Básica e Aplicada da FMRP/USP (IBA/FMRP/USP), pela seriedade, competência, amizade e carinho dedicados durante o mestrado.

Aos amigos e colaboradores do Laboratório de Imunoendocrinologia e Regulação (LIR), Ton e Viviani, pela amizade verdadeira e ímpar dentro e fora do laboratório, pelo constante apoio em todos os assuntos, até mesmo nos experimentos infindáveis; sem o ombro de vocês, as atribulações seriam mais difíceis. Ainda, agradeço aos amigos Giuliano, Patrícia, 
Vanessa e Angélica pela amizade, pelas incessantes ajudas com os experimentos, pelos momentos de descontração compartilhados e pelo apoio nos momentos difíceis.

À técnica e amiga Lelis por seu sorriso e bom humor diários, pelo carinho e pela competência em realizar a grande demanda de trabalho no laboratório.

Ao Prof. Dr. Javier Emílio Lazo Chica que colaborou e enriqueceu este trabalho auxiliando nas análises histológicas.

A todos os funcionários da FMRP e FCFRP, em especial: Denise, Fabiana, Carol, Carlos, Ronaldo, Reinaldo, Fabio, Antonio Flávio e Rinaldo pela amizade, pelo cuidado na limpeza, organização e manipulação dos equipamentos, pelo auxílio e prestação de serviços nas aquisições de citometria de fluxo, pelo primoroso zelo na distribuição e manutenção dos animais de laboratório, pela paciência em explicar técnicas científicas, pela compreensão com os imprevistos e pela disposição ininterrupta em ajudar a superar os mais diversos contratempos.

A todos os professores e alunos dos cursos de Pós-graduação da IBA/FMRP e de Biociências Aplicadas à Farmácia (BAF/FCFRP) pela competência, pela excelência das disciplinas, pelo profícuo compartilhamento de experiências e pelo convívio harmonioso.

Às minhas amigas e ex-orientadoras Majô (Prof ${ }^{a}$. Dr ${ }^{\mathrm{a}}$. Maria José Alves da Rocha) e Gabi (Dra. Gabriela Ravanelli de Oliveira Pelegrin) pela amizade e carinho contínuos. Minha eterna gratidão às responsáveis pelo início de minha carreira, pelos constantes estímulos e por terem contribuído ininterruptamente para minha formação científica.

Às Profas ${ }^{\text {as }}$ Dra . Lúcia Helena Faccioli, Dra . Márcia Regina Von Zeska Kress e Dra. Juliana Pfrimer Falcão pela contínua solicitude e por compartilharem equipamentos e reagentes de seus laboratórios.

Aos amigos da Universidade de Yale, EUA, pelo acolhimento, carinho, paciência e contribuição excepcional no que se refere ao meu enriquecimento profissional: Dr. Martin Kriegel, Dr. Silvio Vieira, Michael, John, Carina, Woojin, Bill, Andrew, Dr. Michael Cappello, Dr. Elijah Paintsil, Dra ${ }^{a}$ Lisa Harrison, Amos, Tracy.

Aos amigos que participaram do Programa "International Training Center for Global 
Infectious Diseases Research (ITC-GIDR)", da Universidade de Yale, EUA: Danillo, Jana, Breno, Valdecir, Christiana, Kwabena, Hector, Esinam.

Às agências financiadoras FAPESP, CAPES, CNPq, FAEPA e NAP-DIN pelo auxílio financeiro para realização deste e de outros trabalhos de nosso laboratório, além de outros projetos dos quais colaboramos.

Aos meus familiares e amigos que sempre estiveram ao meu lado. Não seria capaz de descrever o significado de vocês na minha vida.

A todos que contribuíram direta ou indiretamente para a realização deste trabalho, em meu crescimento científico, pessoal, profissional e humano durante esse período. 
"O preferivel não é o desejo de acreditar, mas o desejo de descobrir, que é exatamente o oposto."

Bertrand Russell

"A tarefa não é tanto ver aquilo que ninguém viu, mas pensar o que ninguém ainda pensou sobre aquilo que todo mundo vê." Arthur Schopenhauer 


\section{SUMÁRIO}

ABREVIATURAS , SIGLAS E SÍMBOLOS ............................................................... i

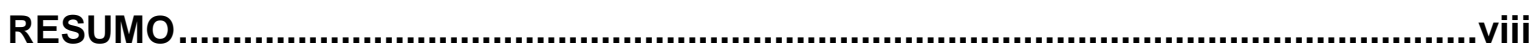

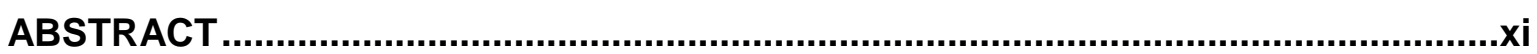

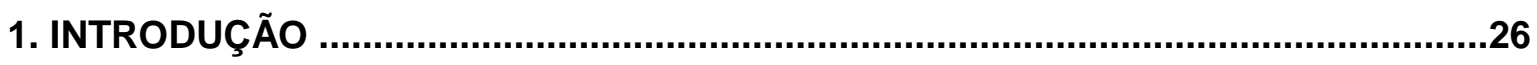

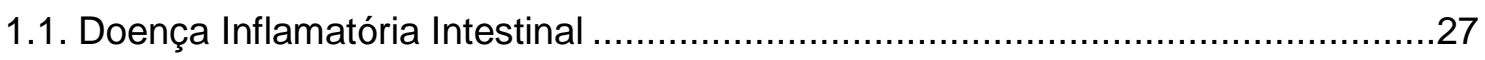

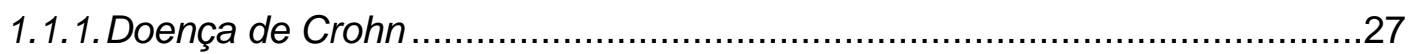

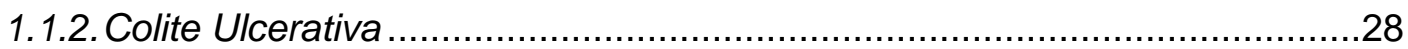

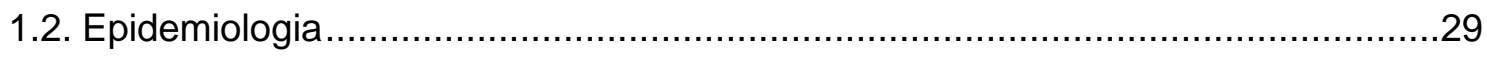

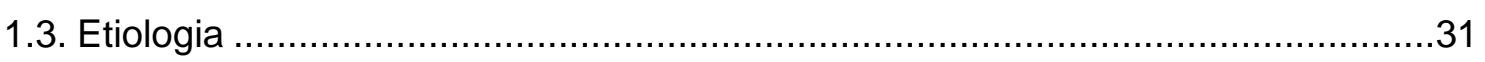

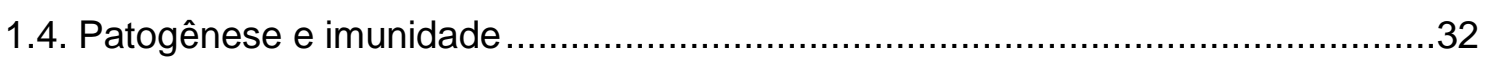

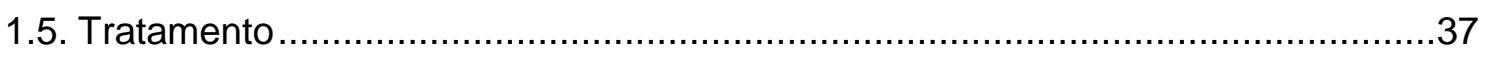

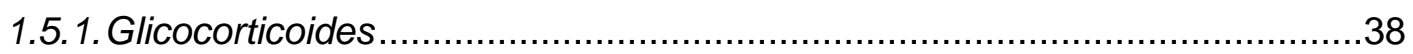

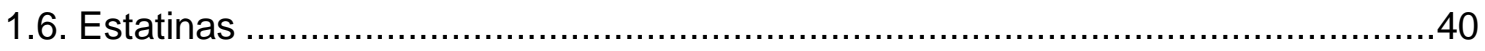

1.7. Associação de glicocorticoides e estatinas ................................................43

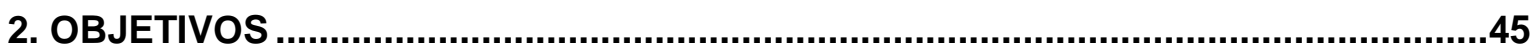

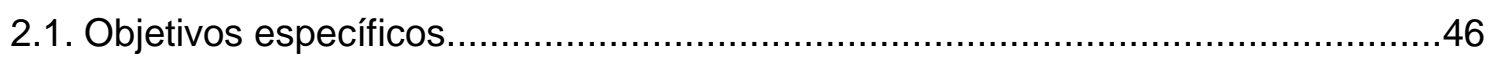

3.MATERIAL E MÉTODOS ......................................................................................47

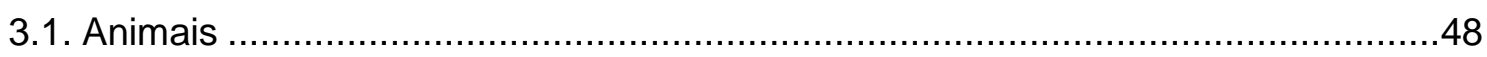

3.2. Colite experimental induzida por dextran sulfato de sódio ................................48

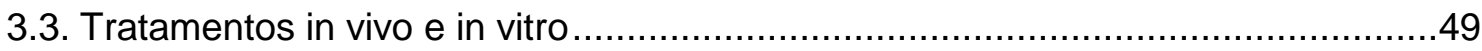

3.4. Parâmetros avaliados na colite experimental induzida por dextran sulfato de sódio

3.4.1. Consumo de dextran sulfato e sódio, aferição do peso corporal e escore clínico..

3.4.2. Escore pós-morte e escore acumulado ...............................................53

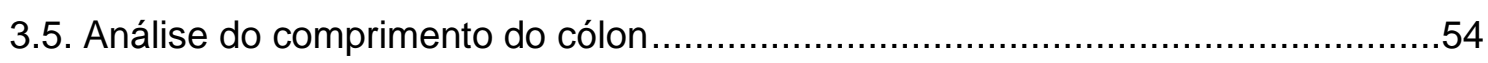

3.6. Fragmentação do cólon e direcionamento das amostras..................................54

3.7. Obtenção de soro, contagem total e diferencial de células do sangue periférico ..55

3.8. Ensaio para quantificação indireta de neutrófilos, macrófagos e eosinófilos.........55

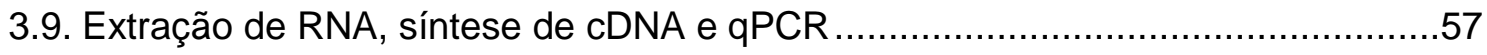

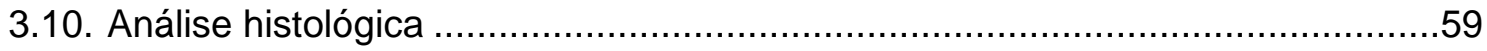

3.11. Extração de leucócitos dos tecidos ....................................................6

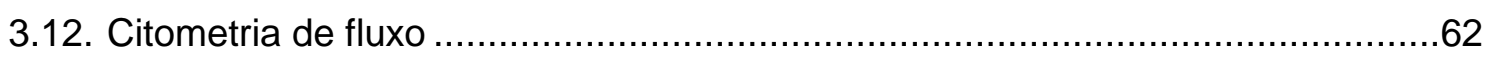

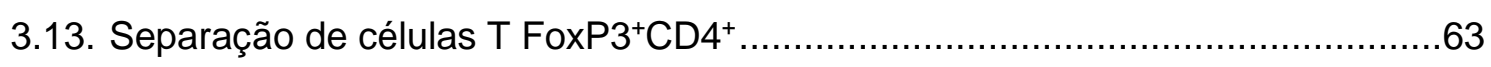


3.14. Ensaio de proliferação celular com carboxifluoresceína succinimidil éster

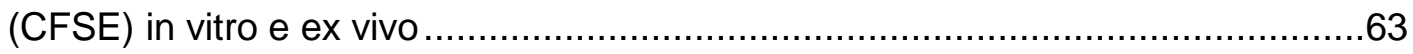

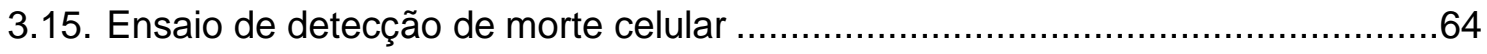

3.16. Cultura ex vivo de esplenócitos na presença de células $\mathrm{T} \mathrm{CD}^{+} \mathrm{FoxP}^{+}$e ensaio de proliferação celular pela incorporação de bromodeoxiuridina ..........................65

3.17. Dosagem de citocinas e Fas-L por imunoensaio enzimático (ELISA)................66

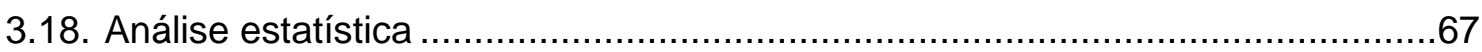

4. RESULTADOS.

4.1. Determinação das doses e via de administração de atorvastatina para o tratamento da colite experimental

4.2. Determinação da via de administração e validação da dose de dexametasona para o tratamento da colite experimental.

4.3. Avaliação do tratamento contínuo com dexametasona e atorvastatina na colite experimental

4.4. Avaliação do tratamento em curto prazo com dexametasona e atorvastatina.......78

4.5. Análise do comprimento do cólon após tratamento com dexametasona e atorvastatina

4.6. Avaliação das alterações histopatológicas no cólon após tratamento com dexametasona e atorvastatina.

4.7. Quantificação de mieloperoxidase, N-acetilglicosaminidase e eosinófiloperoxidase.

4.8. Quantificação de leucócitos totais em diferentes tecidos, quantificação de linfócitos intraepiteliais e contagem diferencial de leucócitos.

4.9. Quantificação de Fas ligante no cólon de animais tratados com dexametasona e/ou atorvastatina

4.10. Avaliação da expressão de RNAm de moléculas inflamatórias após tratamento com dexametasona e atorvastatina

4.11. Perfil fenotípico de macrófagos, células dendríticas, células NK, células NKT e linfócitos $\mathrm{T}$ nos diferentes órgãos após tratamento com dexametasona e atorvastatina.

4.12. Perfil fenotípico de células T reguladoras após tratamento com dexametasona e atorvastatina.

4.13. Influência dos tratamentos com dexametasona e atorvastatina na produção de citocinas por células do baço e linfonodos mesentéricos.

4.14. Cultura de esplenócitos e tratamento in vitro com dexametasona e atorvastatina. 
4.15. Quantificação de citocinas no sobrenadante da cultura de esplenócitos tratados com dexametasona e atorvastatina

4.16. Avaliação de morte celular induzida pelo tratamento in vitro com dexametasona e atorvastatina

4.17. Cultura ex vivo de esplenócitos de camundongos tratados com dexametasona e atorvastatina

4.18. Estudo da suscetibilidade de esplenócitos de camundongos tratados com dexametasona e atorvastatina à supressão por células $\mathrm{CD}^{+}{ }^{+} \mathrm{FoxP} 3^{+}$

5. DISCUSSÃO 115

6. CONCLUSÕES 132

7. REFERÊNCIAS BIBLIOGRÁFICAS 134

8. ANEXOS 155

8.1. Parecer da comissão de ética em experimentação animal 156 
Abreviaturas, Siglas e simbolos/i

ABREVIATURAS, SIGLASE

SÍMBOLOS 


\section{ABREVIATURAS, SIGLAS E SÍMBOLOS}

oC - Graus Celsius.

$\Delta$ - Variação.

$\mu \mathrm{L}$ - Microlitro.

$\mu \mathrm{m}$ - Micrometro.

$\mu \mathrm{M}$ - Micromolar.

ANCA - Anticorpos contra estruturas citoplasmáticas dos neutrófilos, do inglês "anti-neutrophil cytoplasmic antibody".

ANOVA - Análise de variância simples.

APCs - Células apresentadoras de antígenos, do inglês "antigen presenting cells".

ASCA - Anticorpos anti-Saccharomyces cerevisiae, do inglês "anti-Saccharomyces cerevisiae antibody".

ATO - Atorvastatina.

BrdU - Bromodeoxiuridina.

BSA - Fração V da albumina sérica bovina, do inglês "bovine serum albumin".

CAPES - Coordenação de Aperfeiçoamento de Pessoal de Nível Superior.

CCL - Ligante de quimiocina com motivos C-C, do inglês "chemokine (C-C motif) ligand".

CD - Doença de Crohn, do inglês “Crohn's disease”.

CD (acompanhado de um número) - Grupamento de diferenciação, do inglês "cluster of differentiation".

cDNA - DNA complementar, do inglês "complementary DNA".

CEUA - Comitê de Ética no Uso de Animais.

CFSE - Carboxifluoresceína succinimidil éster.

$\mathrm{CO}_{2}$ - Dióxido de carbono.

COBEA - Colégio Brasileiro de Experimentação Animal.

ConA - Concanavalina A.

cm - Centímetros.

CNPq - Conselho Nacional de Desenvolvimento Científico e Tecnológico. 
CTLA-4 - Antígeno 4 associado ao linfócito T citotóxico, do inglês "cytotoxic T-lymphocyteassociated protein 4".

$\mathbf{C X}_{3} \mathbf{C R} 1$ - Receptor 1 da quimiocina $\mathrm{CX}_{3} \mathrm{C}$, do inglês " $C X_{3} C$ chemokine receptor 1 ".

CXCL - Ligante de quimiocina $\mathrm{C}-\mathrm{X}-\mathrm{C}$, do inglês "Chemokine $(C-X-C$ motif) ligand".

DCs - Células dendríticas, do inglês "dendritic cells".

DIl - Doença(s) inflamatória(s) intestinal(is).

DNA - Ácido desoxirribonucleico, do inglês "deoxyribonucleic acid".

dNTP - Desoxirribonucleotídeos trifosfato, do inglês "deoxynucleotide triphosphates".

DO - Densidade óptica.

DPOC - Doença pulmonar obstrutiva crônica.

DSS - Dextran sulfato de sódio.

DX - Dexametasona.

DX + ATO - Dexametasona + Atorvastatina.

EDTA - Ácido etilenodiamino tetra-acético, do inglês "ethylenediaminetetraacetic acid".

ELISA - Imunoensaio enzimático, do inglês "Enzyme Linked Immuno Sorbent Assay".

eNOS - Óxido nítrico sintase endotelial (enzimas), do inglês "endothelial nitric oxide synthase".

EPO - eosinófilo-peroxidase (enzimas).

EUA - Estados Unidos da América.

FACS - Separação de células ativada por fluorescência, do inglês "Fluorescence-activated Cell Sorting".

FAPESP - Fundação de Amparo à Pesquisa do Estado de São Paulo.

Fas-L (CD178; TNFSR6) - Fas ligante

FCFRP - Faculdade de Ciências Farmacêuticas de Ribeirão Preto.

FMRP - Faculdade de Medicina de Ribeirão Preto.

FoxP3+ - do inglês "Forkhead box P3".

g - Gramas.

$\boldsymbol{g}$ - Gravidade.

G - Gauge. 
GATA-3 - Proteína de ligação GATA 3, do inglês "GATA binding protein 3".

GCs - Glicorticoides.

GFP - Proteína fluorescente verde, do inglês "green fluorescent protein".

GITR - Membro da superfamília do receptor de TNF induzido por glicocorticoides, do inglês "glucocorticoid-induced TNF receptors family".

GWAS - Estudos de associação ampla do genoma, do inglês "genome-wide association studies".

H\&E - Hematoxilina e eosina.

$\mathrm{H}_{2} \mathrm{O}$ - Água.

$\mathrm{H}_{2} \mathrm{SO}_{4}$ - Ácido sulfúrico.

HBSS - Solução salina balanceada de Hanks, do inglês "Hank's balanced salt solution".

HEPES - Ácido N-2-hidroxietilpiperazina-N'-2-etanosulfônico.

HCl - Ácido clorídrico.

HMG-CoA - 3-Hidróxi-3-metilglutaril coenzima A.

HTAB - brometo de hexadeciltrimetilamônio, do inglês "hexadecyltrimethylammonium bromide”.

IEC - Células epiteliais intestinais, do inglês "intestinal epithelial cells".

i.p. - intraperitoneal.

IkBa - Inibidor do fator de transcrição nuclear kB (NFkB), do inglês "NF-kB inhibitor alpha".

IBD - Doença Inflamatória Intestinal, do inglês "Inflammatory bowel disease".

IDO - Indoleamina 2,3-dioxigenase.

IFN- $\mathbf{Y}$ - Interferon gama.

IL - Interleucina.

ILC - Células linfoides inatas, do inglês "innate lymphoid cells".

kg - Quilograma.

$\mathrm{KHCO}_{3}$ - Carbonato de potássio.

$\mathrm{KH}_{2} \mathrm{PO}_{4}$ - Fosfato monopotássico.

LDL-C - Lipoproteínas de baixa densidade ligadas ao colesterol, do inglês "Low density 
lipoprotein cholesterol".

LIE - Linfócitos intraepiteliais.

LIR - Laboratório de Imunoendocrinologia e Regulação.

LNM - Linfonodo mesentérico.

LP - Lâmina própria.

LPS - Lipopolissacarídio.

M - Molar.

MCP-1 - Proteína quimiotática de monócitos, do inglês "monocyte chemoattractant protein 1". mg - Miligrama.

$\mathrm{MgCl}_{2}$ - Cloreto de magnésio.

MHC - Complexo principal de histocompatibilidade, do inglês "major histocompatibility complex".

mL - Mililitros.

MLN - Linfonodo mesentérico, do inglês "mesenteric lymph node".

mm - Milímetros.

mM - Milimolar.

MPO - Mieloperoxidase (enzimas).

n - Número de animais.

N - Normal.

$\mathrm{Na}_{2} \mathrm{HPO}_{4}$ - Fosfato de sódio dibásico.

$\mathrm{NaCl}$ - Cloreto de sódio.

NAG - N-acetil- $\beta$-D-glicosaminidase (enzimas).

$\mathrm{NaHCO}_{3}$ - Bicarbonato de sódio.

NFAT - Fator nuclear de células T ativadas, do inglês nuclear factor of activated T-cells.

NF-kB - Fator nuclear kB, do inglês "nuclear factor kB".

$\mathrm{NH}_{4} \mathrm{Cl}$ - Cloreto de amônio.

NK - Exterminadora natural (célula), do inglês "natural killer". 
NLRs - Receptores do tipo NOD, do inglês "NOD-like receptors".

nm - Nanômetro.

nM - Nanomolar.

NO - Óxido nítrico, do inglês "nitric oxide".

NOD - Domínio de oligomerização de ligação a nucleotídeos, do inglês "Nucleotide-binding oligomerization domain".

OPD - Dicloridrato de o-fenilenodiamina, do inglês "o-phenylenediamine dihydrochloride".

p - Nível descritivo.

PAMPs - Padrões Moleculares Associados a Patógenos, do inglês "pathogen-associated molecular patterns".

PBS - Solução salina tamponada com fosfato, do inglês "phosphate buffered saline".

PD-1 - Proteína de morte celular programada 1, do inglês "programmed cell death 1".

pg - Picograma(s).

pH - Potencial hidrogeniônico.

PI - lodeto de propídio, do inglês "propidium iodide".

PMA - Forbol-12-miristato-13-acetato, do inglês "phorbol-12-myristate-13-acetate".

PP - Placas de Peyer.

PPAR - Receptores ativados por proliferadores de peroxissomo, do inglês "peroxisome proliferator-activated receptor".

PRRs - Receptores de reconhecimento padrão, do inglês "pattern recognition receptors".

qPCR - Reação em cadeia da polimerase quantitativa (ou em tempo real), do inglês "quantitative polymerase chain reaction".

R-GCs - Receptores de glicocorticoides.

R-LDL - Receptores de lipoproteínas de baixa densidade.

RNA - Ácido ribonucleico, do inglês "ribonucleic acid".

RNAm - RNA mensageiro.

RORyt - Receptor Órfão Relacionado ao Receptor de Ácido Retinoico yt.

RPMI - Meio de cultura RPMI 1640. 
RXR - Receptor retinoide X, do inglês "retinoid X receptor".

SFB - Soro fetal bovino.

SPF - Livre de patógenos específicos (condições), do inglês "specific pathogen-free"

STAT - Transdutor de sinal e ativador da transcrição, do inglês "signal transducer and activator of transcription".

T CD4+ - Linfócito T CD4+.

T CD8+ - Linfócito T CD8+.

T-bet - Fator de transcrição específico de linfócitos Th1, do inglês "Th1-specific T-box transcription factor".

TCR - Receptor de células T, do inglês "T cell receptor".

TGF- $\boldsymbol{\beta}$ - Fator de crescimento e transformação beta, do inglês "transforming growth factor beta".

Th - Linfócito T auxiliar, do inglês "T helper".

TLR - Receptores Tipo Toll, do inglês "Toll-like receptors".

TMB - 3,3',5,5'-tetrametilbenzidina.

TNBS - Ácido 2,4,6-trinitrobenzenosulfônico, do inglês "2,4,6-trinitrobenzenesulfonic acid".

TNF - Fator de necrose tumoral, do inglês "tumor necrosis factor".

Treg(s) - Linfócito(s) T regulador(es).

UC - Colite ulcerativa, do inglês "ulcerative colitis".

UFTM - Universidade Federal do Triângulo Mineiro.

UI - Unidades internacionais.

USP - Universidade de São Paulo.

v.o. - Via oral.

VLDL - Lipoproteína de muita baixa densidade, do inglês "very low-density lipoprotein". WT - Camundongos do tipo selvagem, do inglês "wild type". 
BASSO, P. J. Avaliação dos efeitos imunomoduladores de estatinas e glicocorticoides na terapêutica da colite experimental. 2015. 156f. Dissertação de Mestrado - Faculdade de Medicina de Ribeirão Preto, Universidade de São Paulo, Ribeirão Preto, São Paulo, 2015.

A Doença de Crohn (CD) e a Colite Ulcerativa (UC) são as principais enfermidades componentes das Doenças Inflamatórias Intestinais (DII). Embora existam vários medicamentos atualmente empregados para atenuar a inflamação descontrolada no intestino, tratar as complicações ou prolongar os períodos de remissão clínica, não há, ainda, uma terapia que seja totalmente efetiva para estas doenças. Os glicocorticoides (GCs), antiinflamatórios comumente usados nas DII, possuem eficácia limitada e mais da metade dos pacientes se tornam refratários ou dependentes da medicação. Por outro lado, as estatinas são conhecidas por possuírem propriedades pleiotrópicas e seu uso concomitante com os GCs tem gerado boas perspectivas em várias doenças autoimunes e inflamatórias, inclusive nas DII. Apesar de já existirem indicativos de melhora de pacientes com DII pela utilização combinada destas drogas, ainda há escassez de dados que mostrem as alterações causadas no sistema imunológico. Assim, o objetivo desse trabalho foi avaliar os efeitos imunomoduladores do uso concomitante de GCs e estatinas na colite experimental induzida por dextran sulfato de sódio (DSS) em camundongos C57BL/6. Os resultados mostraram que o uso contínuo de GCs (dexametasona - DX), associados ou não a estatinas (atorvastatina ATO), não alterou o curso da doença e antecipou a morte dos camundongos, enquanto que o oposto foi observado com o uso isolado de ATO. Tratamentos em curto prazo (3 doses) contendo ATO (isolada ou associada à DX) causaram melhora clínica e histológica dos animais doentes, diminuíram o número de leucócitos circulantes (principalmente monócitos) e de células mononucleares na lâmina própria (LP), a frequência de células CD11 b+ na $L P$, a frequência de células dendríticas (DCs) $C D 11 b^{+} C D 11 c^{+}$e $C D 11 b-C D 11 c^{+}$no baço e a frequência de células $\mathrm{CD}^{+}$produtoras de IFN-y nos linfonodos mesentéricos (LNM). Entretanto, ambos os esquemas terapêuticos aumentaram a frequência de linfócitos T CD8+ no baço e LNM. Ainda, as terapias inibiram a proliferação de esplenócitos tratados in vitro, 
diminuíram a síntese de IL-6 e, quando em baixas concentrações, aumentaram a produção de IL-10. Diferencialmente, o tratamento combinado pareceu exercer os efeitos acima descritos de modo mais pronunciado do que o uso isolado de estatina. Adicionalmente, diminuiu os níveis de expressão de RNAm das citocinas IL-1 $\beta$, IL-17 e IFN- $y$ no local da inflamação, reduziu o número de linfócitos circulantes, de leucócitos no baço e LNM e de linfócitos $T C D 4^{+}$nos LNM, além de ter aumentado a frequência de DCs CD11b-CD11 ${ }^{+}$na LP e a concentração de Fas-L no intestino grosso. Considerando o uso em curto prazo com ATO isolada, foi observado aumento da frequência de DCs CD11b CD11 ${ }^{+}$nos LNM e de células Natural killer (NK) no baço dos camundongos doentes e diminuição dos níveis de expressão de RNAm de PPAR-y no intestino grosso. O uso isolado de DX em curto prazo melhorou os aspectos histológicos, diminuiu o número de macrófagos e os níveis de IFN-ץ no cólon, diminuiu o número de leucócitos circulantes (principalmente linfócitos), aumentou a frequência de células $C D 11 b^{+}$no baço e a síntese de IL-10 por esplenócitos ex vivo. Apesar da frequência de células $T$ reguladoras (Treg) e da susceptibilidade dos esplenócitos à sinais reguladores não terem sido modificados após os diferentes tratamentos, nossos resultados sugerem que as estatinas usadas isoladamente preservaram a resposta inflamatória do organismo de modo eficiente e controlado, enquanto que o uso associado das drogas causou a imunossupressão dos animais doentes, contribuindo para as complicações clínicas decorrentes da colite experimental induzida por DSS.

Palavras chave: Doença inflamatória intestinal. Inflamação. Tratamento. 
ABSTRACT 
BASSO, P. J. Evaluation of the immune modulatory effects of statins and glucocorticoids in experimental colitis. 2015. 156s. Master Thesis - School of Medicine of Ribeirão Preto, University of São Paulo, Ribeirão Preto, São Paulo, 2015.

Crohn's disease (CD) and Ulcerative colitis (UC) are the main conditions that comprise the Inflammatory Bowel Diseases (IBD). The conventional drug therapies for IBD aim to attenuate the uncontrolled inflammation in the intestinal mucosa, to treat the complications and to extend clinical remission. However, all available drugs have unpredictable or limited effects. Glucocorticoids (GCs) are commonly anti-inflammatory drugs, which are associated to refractoriness and/or dependence in over half of IBD patients. On the other hand, statins have pleiotropic properties and the concomitant use with GCs has shown good prospects in several autoimmune and inflammatory diseases, including IBD. Despite the putative clinical improvement after combined use of GCs and statins in IBD, there is a lack of data indicating their additive effects on the immune system. Therefore, the purpose of this study was to evaluate the immune modulatory effects of the concomitant use of statins and GCs in experimental colitis induced by dextran sulfate sodium (DSS). The results showed that longterm use of GCs (dexamethasone - DX), alone or associated to statins (atorvastatin - ATO), did not improve the clinical signs and increased the death rates of C57BL/6 mice exposed to DSS, while the opposite was observed after treatment with statins alone. Short-term use of ATO (3 doses), alone or associated to DX, improved the clinical signs and histological parameters in DSS-exposed mice, decreased the number of white blood cells (mainly monocytes), the number of mononuclear cells in the lamina propria (LP), the frequency of CD11 $b^{+}$cells in the LP, the frequency of $C D 11 b^{+} C D 11 c^{+}$and CD11b-CD11c dendritic cells (DCs) in the spleen and the frequency of IFN-y-producing CD4 ${ }^{+} \mathrm{T}$ cells in the mesenteric lymph nodes (MLN). However, ATO alone or associated to DX lead to increased CD8+ T lymphocytes in the spleen and MLN. Moreover, both therapies containing ATO inhibited the proliferation of in vitro-treated splenocytes, besides decreasing IL-6 and increasing IL-10 synthesis. Differentially, the association of drugs led to a more pronounced effects over the changes 
mentioned above than the single use of statin and additionally decreased IL-1 $\beta$, IL-17 and IFNY mRNA expression levels at the intestinal tissue, the number of circulating lymphocytes, the number of leukocytes in spleen and MLN and the frequency of CD4+ $\mathrm{T}$ lymphocytes in the MLN. In addition, statins and GCs increased the frequency of CD11b-CD11 $\mathrm{c}^{+}$DCs in LP and the Fas- $L$ concentrations in the large intestine. Considering the short-term use of ATO there was increased frequency of CD11b-CD11 $\mathrm{c}^{+} \mathrm{DCs}$ in MLN, increased frequency of natural killer (NK) cells in the spleen and decreased mRNA expression of PPAR-y in the large intestine. The short-term use of DX improved the histology parameters, decreased the number of macrophages and IFN-y levels in the colon, reduced the number of circulating leukocytes (mainly lymphocytes), and increased the frequency of $\mathrm{CD} 11 \mathrm{~b}^{+}$cells in spleen and IL-10 synthesis by ex vivo splenocytes. Finally, since both regulatory T cells (Treg) frequency and the splenocytes susceptibility to regulatory signals have not been modified after the different treatments, our findings suggest that single use of statins preserved an efficient and controlled inflammatory response, while the combined use of GCs and statins led to immunosuppression, which probably contributed to long-term clinical complications of DSS-induced colitis.

Keywords: Inflammatory bowel disease. Inflammation. Treatment. 
I. INTRODULCÃO 


\section{INTRODUÇÃO}

\subsection{Doença Inflamatória Intestinal}

A Doença Inflamatória Intestinal (DII) compreende um grupo de doenças inflamatórias crônicas e recidivantes do trato digestório e engloba principalmente a Doença de Crohn (CD - Crohn's disease) e a Colite Ulcerativa (UC - ulcerative colitis). Entretanto, a DII também inclui enfermidades menos frequentes como a colite colagenosa e a colite linfocítica, ambas agrupadas sob a denominação de Colites Microscópicas (LATELLA; PAPI, 2012; MARTINS; PEPPERCORN, 2004).

A CD e a UC estão altamente relacionadas entre si e são caracterizadas por seu curso crônico, pela alternância de períodos de atividade, gravidade variável, períodos de remissão clínica e manifestações extraintestinais, podendo acometer os sistemas musculoesquelético (artrite), dermatológico, oral, hepatobilipancreático, ocular, renal, pulmonar e metabólico (BAUMGART; SANDBORN, 2007; LEVINE; BURAKOFF, 2011; RODRIGUEZ-MORANTA; SORIANO-IZQUIERDO; GUARDIOLA, 2007). Tal semelhança faz com que cerca de $10 \%$ dos pacientes com DII não tenham o diagnóstico clínico definido como CD ou UC e a doença é denominada Colite Indeterminada (TREMAINE, 2011). Apesar desta paridade, as DII ainda possuem características suficientemente distintas para serem consideradas entidades autônomas, dentre elas a distribuição e os tipos de lesões no trato gastrointestinal, a histopatologia, a dinâmica da resposta imunológica e a resposta aos diferentes tipos de tratamentos (KARLINGER et al., 2000; MARTINS; PEPPERCORN, 2004; PRIDEAUX; DE CRUZ; et al., 2012).

\subsubsection{Doença de Crohn}

A CD pode acometer qualquer parte do trato gastrointestinal, da orofaringe à região perianal, mas normalmente se localiza no íleo terminal e/ou cólon proximal, geralmente com 
lesões descontínuas e transmurais, que podem resultar em fístulas, abscessos e estenoses (KALLA et al., 2014; VAN ASSCHE et al., 2010).

A histologia da CD caracteriza-se pela presença de granulomas epitelioides, arquitetura descontínua da cripta intestinal, preservação de mucina em sítios ativos e pequenas ulcerações superficiais sobre as Placas de Peyer (PP) (GEBOES, 2008; HENDRICKSON; GOKHALE; CHO, 2002).

Já os sinais clínicos dependem da localização anatômica, extensão e gravidade das lesões. O acometimento da região gastroduodenal é geralmente caracterizado por saciedade precoce, náuseas, emese, dor epigástrica e/ou disfagia. Quando a doença está localizada principalmente no intestino delgado ela pode se manifestar como dor abdominal difusa, anorexia, diarreia e/ou perda de peso. No intestino grosso os principais sinais são enterorragia, diarreia muco-sanguinolenta e/ou cólicas abdominais, geralmente aliviadas após defecação (HENDRICKSON et al., 2002; KALLA et al., 2014; MARTINS; PEPPERCORN, 2004; VAN ASSCHE et al., 2010).

Análises laboratoriais mostram que a maioria dos pacientes com CD apresentam anticorpos anti-Saccharomyces cerevisiae (ASCA) circulantes, no entanto esse aspecto não é patognomônico (BAUMGART; SANDBORN, 2007; PRIDEAUX; DE CRUZ; et al., 2012).

Considerando a dinâmica da resposta imunológica, a CD é caracterizada por uma resposta do tipo T auxiliar (Th - T helper) 1 e Th17 (FUSS, 2008; GALVEZ, 2014) e será discutida posteriormente.

\subsubsection{Colite Ulcerativa}

A UC é uma doença na qual a inflamação e as alterações morfológicas estão restritas ao cólon. Inicialmente o reto é acometido e a inflamação é limitada à mucosa e submucosa, mas pode estender-se de forma contínua e difusa por todo o cólon com presença de ulceração, edema e hemorragia (DIGNASS et al., 2012; SEPULVEDA et al., 2008). 
Estudos histopatológicos caracterizam a UC pela grave distorção da arquitetura e diminuição da densidade das criptas intestinais, presença de abscesso críptico, grande aumento celular difuso transmucosa na lâmina própria, depleção de mucina e metaplasia das células de Paneth, distal à flexura hepática (GEBOES, 2008; HENDRICKSON et al., 2002).

O quadro clínico da UC também depende da gravidade e extensão da lesão, mas geralmente se caracteriza por diarreia muco-sanguinolenta (presente em cerca de $90 \%$ dos pacientes), sangramento retal, tenesmo, cólicas abdominais e sintomas gerais como febre, anorexia e perda de peso. Com a evolução do quadro e/ou presença de recidivas frequentes, sinais como anemia, aspecto toxêmico e prostração podem aparecer (DIGNASS et al., 2012; MARTINS; PEPPERCORN, 2004).

Análises sorológicas mostram uma correlação positiva entre pacientes com UC e a presença de anticorpos contra estruturas citoplasmáticas dos neutrófilos (ANCA - antineutrophil cytoplasmic antibody) que podem auxiliar no diagnóstico clínico e endoscópico da doença (BAUMGART; SANDBORN, 2007; PRIDEAUX; DE CRUZ; et al., 2012).

A resposta imunológica do organismo na UC é do tipo Th2 e Th17 (FUSS, 2008; GALVEZ, 2014) e sua dinâmica será discutida posteriormente.

\subsection{Epidemiologia}

As DIl vêm aumentando em todo o mundo nos últimos tempos e afeta principalmente os países desenvolvidos ocidentais, representados principalmente pelas nações norte americanas e oeste europeu (BURISCH; MUNKHOLM, 2013; MOLODECKY et al., 2012). Em 2012, Molodecky e colaboradores relataram que na Europa a incidência anual da CD é de 12,7 por 100.000 pessoas, enquanto que para UC esses números atingiram 24,3/100.000 pessoas-ano. A taxa de prevalência foi de 322 e 505 casos por 100.000 pessoas-ano para CD e UC, respectivamente (MOLODECKY et al., 2012). Ainda, a incidência e prevalência na América do Norte foram de 20,2/100.000 e 309/100.000 pessoas-ano para CD juntamente com 19,2/100.000 e 249/100.000 pessoas-ano para UC, respectivamente (MOLODECKY et al., 2012). Considerando o continente asiático e os países em desenvolvimento, o número de 
casos de DII também parece estar aumentando, contudo as avaliações sobre a evolução da doença nos países emergentes em todo o globo permanecem escassas (NG et al., 2013; WONG; NG, 2013). No Brasil isso não é diferente: além do baixo número de estudos encontrados na literatura sobre o tema, os mesmos têm considerado apenas pequenas populações de um mesmo local que, somado ao fato do tamanho e da heterogeneidade da população brasileira, podem não refletir o perfil epidemiológico real da DII no país. Dentro deste contexto, de modo geral, tanto a prevalência como a incidência de DII no Brasil ainda são consideradas baixas, mas acompanham o crescimento contínuo no número de casos observados no restante do mundo (PARENTE et al., 2015; VICTORIA; SASSAK; NUNES, 2009).

Os caucasianos parecem ser os mais acometidos pela DII, mas esse predomínio parece estar diminuindo, uma vez que a doença está se espalhando por todo o globo (NGUYEN; CHONG; CHONG, 2013; PRIDEAUX; KAMM; et al., 2012). Ainda, a CD afeta proeminentemente indivíduos do sexo feminino, enquanto não há diferença entre os gêneros na UC (KAPPELMAN et al., 2013; LANGHOLZ, 2010).

Há alguns anos, estudos mostraram que a CD e a UC eram mais prevalentes na segunda e terceira décadas de vida, respectivamente, também com grande ocorrência entre os 50 e 70 anos de idade (LOFTUS; SANDBORN, 2002). Entretanto, estudos atuais mostram que as doenças afetam indivíduos principalmente entre a faixa etária dos 30 e início dos 40 anos de vida, com grande aumento no número de casos pediátricos (BENCHIMOL et al., 2011; KAPPELMAN et al., 2013; NG et al., 2013). A idade parece influenciar o prognóstico da DII, uma vez que o risco de desenvolver câncer colorretal parece ser menor em pacientes com início da doença após a terceira década de vida (JESS et al., 2012).

O impacto das DII na qualidade de vida dos doentes é alto devido aos grandes índices de morbidade, necessidades de hospitalização e cirurgias, tratamentos longos e onerosos, além de aumentar as probabilidades de desenvolvimento de câncer colorretal (M'KOMA, 2013; TERZIC et al., 2010). Apesar dos pacientes com DIl exibirem um risco de morte relativamente baixo, eles possuem uma taxa de mortalidade maior quando comparados a 
indivíduos saudáveis (BEWTRA et al., 2013). Além disso, as chances de óbito aumentam significativamente quando acompanhadas de certas condições clínicas, como câncer colorretal e de manifestações extraintestinais, tais como doenças pulmonares e hepáticas (BEWTRA et al., 2013; CARD; HUBBARD; LOGAN, 2003). Como resultado, recursos exorbitantes são despendidos para o atendimento, tratamento e acompanhamento de pacientes portadores de DII (BUCHANAN et al., 2011).

\subsection{Etiologia}

A etiologia das DIl ainda permanece incompreendida, mas características genéticas, microbianas, ambientais e imunológicas influenciam no desenvolvimento dessas doenças (BASSO et al., 2014). Estudos mostram que quanto mais próximo geneticamente o membro da família for do portador de DII, maior a probabilidade de se desenvolver a DII (EK; D'AMATO; HALFVARSON, 2014; RUSSELL; SATSANGI, 2008). Além disso, estudos de associação ampla do genoma (GWAS - genome-wide association studies) já identificaram cerca de 100 variações alélicas relacionadas a diferentes suscetibilidades para CD e UC (ANDERSON et al., 2011; FRANKE et al., 2010).

A microbiota intestinal é um fator altamente relevante na DII, uma vez que antígenos bacterianos do lúmen entérico parecem ser os mais importantes agentes inflamatórios no desenvolvimento da doença (HOLD et al., 2014; SARTOR, 2014). A composição da microbiota no trato gastrointestinal está alterada em pacientes com DII, com diminuição de populações bacterianas importantes para a homeostase local (filos Bacteroidetes e Firmicutes) acompanhada do aumento de populações que contribuem para o surgimento da inflamação (filo Proteobacteria) (OTT et al., 2004; WALKER et al., 2011). Além disso, a diminuição de bactérias comensais no intestino leva, consequentemente, à diminuição de metabólitos ativos e benéficos por elas sintetizados, tais como os ácidos graxos de cadeias curtas (acetato e butirato, por exemplo) que, dentre diversas ações anti-inflamatórias no intestino, também têm o papel de aumentar a diferenciação de células $T$ para um perfil regulador (células T reguladoras - Tregs) (FURUSAWA et al., 2013; WALKER et al., 2011). 
Dieta, tabagismo, medicamentos, estado hormonal, prática de exercícios, distúrbios de sono, amamentação adequada na infância e cirurgias (apendicectomia) são exemplos de fatores que podem influenciar direta ou indiretamente e positiva ou negativamente no desenvolvimento das DII (LEE, D. et al., 2015; O'TOOLE; KORZENIK, 2014; SANDS; GRABERT, 2009).

\subsection{Patogênese e imunidade}

Uma das principais características da DII é a inflamação descontrolada da mucosa intestinal que pode acometer diversos segmentos do trato digestório. Desse modo a reação imune é tanto local como sistêmica e envolve elementos da imunidade inata e adaptativa (humoral e celular) (HANAUER, 2006; KARLINGER et al., 2000). De modo geral, praticamente todos os componentes do sistema imune estão alterados e/ou sofrem alteração durante o curso da doença.

O epitélio intestinal, que dentre diversas funções desempenha um papel de barreira física contra agentes agressores externos, é mais fragilizado em indivíduos com DII, apresentando baixa resistência e aumento da permeabilidade da mucosa inflamada e não inflamada (GEROVA et al., 2011; SODERHOLM et al., 2002). Ainda, as células epiteliais intestinais (IEC - intestinal epithelial cells) estão mais suscetíveis à apoptose e descamação durante a doença (KIESSLICH et al., 2012).

Receptores de reconhecimento padrão (PRRs - pattern recognition receptors), presentes na maior parte das células do sistema imune e IEC, também contribuem para o desenvolvimento da doença. Capacitados para reconhecerem componentes microbianos altamente conservados, chamados Padrões Moleculares Associados a Patógenos (PAMPs pathogen-associated molecular patterns), tais como lipopolissacarídio (LPS), peptidoglicano, ácido lipotecoico e DNA/RNA, esses receptores ativam a resposta pró-inflamatória do organismo (KUMAR; KAWAI; AKIRA, 2009). Os receptores tipo Toll (TLR - Toll-like receptors) são importantes PRRs encontrados em mamíferos (IWASAKI; MEDZHITOV, 2004; KUMAR et al., 2009) e, além de possuírem um perfil de expressão alterado, também podem estar hiper 
ou hipoativados nas células de defesa de pacientes com DII, contribuindo para a desregulação das sinalizações celulares e comprometendo a resposta inflamatória (HAUSMANN et al., 2002; PEDERSEN et al., 2005). Polimorfismos em TLR dos tipos 1, 2, 4, 6 e 9 foram identificados na CD e/ou UC e estão associados ao aumento da suscetibilidade à doença (TLR4 e TLR9) e à magnitude ou ao surgimento de comorbidades (TLR1, TLR2 e TLR6) (DE JAGER et al., 2007; PIERIK et al., 2006; TOROK et al., 2009).

Os Receptores Tipo NOD (NLRs - NOD-like receptors) são PRRs citoplasmáticos sensíveis a peptidoglicanos da parede bacteriana e ativam vias de sinalização intracelulares como NF-kB e inflamassoma (FRANCHI et al., 2008). NLRs são expressos em múltiplos tipos celulares, incluindo IEC e células apresentadoras de antígenos (APCs - antigen presenting cells) (KUMAR et al., 2009). Polimorfismos no gene NOD2 estão associados com aumento da suscetibilidade a infecções bacterianas no lúmen intestinal, provavelmente por diminuir a síntese de a-defensinas e outros peptídeos antimicrobianos produzidos por células epiteliais intestinais especializadas (células de Paneth) (HUGOT et al., 2001; WEHKAMP et al., 2005). Desse modo, esses receptores tornam-se ineficazes contra os microrganismos intestinais que, por sua vez, conseguem atravessar o epitélio já fragilizado, iniciando uma reação inflamatória crônica na parede intestinal.

O reconhecimento e processamento de antígenos luminais têm início no epitélio intestinal pelas APCs, como as células dendríticas (DCs - dendritic cells), os macrófagos e as células B (MANN; LI, 2014). As DCs são fundamentais para o controle da imunidade contra patógenos e para a tolerância imunológica e suas funções são reguladas pela localização, pelo número e pelo estágio de maturação (NIESS, 2008). Essas células e seus subtipos são geralmente caracterizados pela expressão de integrinas, tais como CD11b, CD11c e CD103, além do receptor 1 da quimiocina $\mathrm{CX}_{3} \mathrm{C}$ (CX $\left.{ }_{3} \mathrm{CR} 1\right)$ (VAROL; ZIGMOND; JUNG, 2010). Portando um grande espectro de PRRs, essas células tipicamente projetam seus dendritos para o lúmen intestinal e conseguem distinguir bactérias comensais de patogênicas, além de terem a capacidade de ativar ou silenciar respostas de células T (IWASAKI; MEDZHITOV, 2004; NIESS et al., 2005). Com o grande aporte de antígenos oferecidos às DCs no epitélio 
intestinal durante a DII, elas modificam seu fenótipo imaturo para maduro e induzem respostas imunes efetoras (STEINMAN; NUSSENZWEIG, 2002). O número e a responsividade dessas APCs frente a estímulos parecem estar aumentados em pacientes com DIl e em modelos experimentais de colite (BAUMGART et al., 2009; VAROL et al., 2010).

Os macrófagos também são APCs e estão presentes em praticamente todos os tecidos do corpo humano, desempenhando papéis na eliminação de patógenos, ativação de células T e produção de citocinas para o recrutamento de leucócitos ao local da inflamação (MALOY; POWRIE, 2011). Tipicamente os macrófagos são caracterizados pela baixa expressão da integrina CD11c, pela presença de CD11b e da glicoproteína F4/80 (EMR1 em humanos); seus diferentes subtipos também são caracterizados pela presença do receptor de quimiocina $\mathrm{CX}_{3} \mathrm{CR} 1$ (HEINSBROEK; GORDON, 2009; VAROL et al., 2010). Em situações de homeostase, os macrófagos intestinais possuem uma população predominante com fenótipo $\mathrm{CX}_{3} \mathrm{CR} 1^{\text {high }}$ não responsiva a estímulos inflamatórios, mas com a capacidade fagocítica preservada (BAIN et al., 2013). Entretanto, na DIl outra população de monócitos com características pró-inflamatórias é recrutada $\left(\mathrm{CX}_{3} \mathrm{CR} 1^{\text {low/int }}\right)$, exacerbando as respostas imunes locais e sistêmicas (BAIN et al., 2013).

As células linfoides inatas (ILC - innate lymphoid cells) também contribuem significativamente para o desenvolvimento e/ou patogênese da DII. As ILC estão envolvidas no remodelamento tecidual, no combate a micróbios, no desenvolvimento de tecidos linfoides e na homeostase tecidual (SPITS; CUPEDO, 2012). Além das bem descritas células exterminadoras naturais (NK - natural killer), as outras subpopulações de ILC têm sido caracterizadas por sintetizarem citocinas pró-inflamatórias semelhantes às produzidas por linfócitos Th1, Th2 e Th17 (SPITS; CUPEDO, 2012). Na DIl, as células NK apresentam aumentada expressão de receptores para a citocina interleucina (IL) 21 (IL-21R), elevando a atividade citotóxica dessas células e expansão de células Th17 (LIU, Z. et al., 2009). Ainda, populações de ILC produtoras de interferon (IFN) y estão aumentadas em pacientes com CD e contribuem para a progressão da inflamação (BERNINK et al., 2013). 
Grande parte das alterações imunológicas discutidas até o momento é devido à desregulação dos níveis e dos subtipos de moléculas que coordenam as respostas e as sinalizações imunológicas, as citocinas. O perfil da síntese de citocinas, produzidas essencialmente por células inflamatórias, irá depender do tipo de DII (BIASI et al., 2013). Como discutido anteriormente, a CD é mediada por linfócitos Th1, que sintetizam principalmente a citocina IFN-y; citocinas como IL-2, IL-6 e fator de necrose tumoral (TNF tumor necrosis factor) também têm importante participação na CD e amplificam os sinais para maior síntese de TNF, IL-6, IL-1ß e IL-12 por macrófagos residentes e DCs (BIASI et al., 2013; NEURATH, 2014). Células Th1, além de serem caracterizadas pela síntese de IFN- $\gamma$, também expressam o fator de transcrição T-bet, responsável por coordenar as respostas do tipo 1 . Diversos estudos clínicos e experimentais já caracterizaram a CD como sendo mediada por respostas Th1 (NEURATH et al., 1995; VERDIER et al., 2012).

Por outro lado, a UC tem uma resposta predominantemente Th2, com produção de IL4, mas também de IL-5 e IL-13, levando ao aumento da resposta humoral e à inibição das respostas Th1 (BIASI et al., 2013; NEURATH, 2014). O fator de transcrição característico de células Th2 é o GATA3. O aumento da síntese de IL-13 no intestino de pacientes com UC foi associado com a disfunção das IEC, que podem morrer por apoptose (HELLER et al., 2005).

Diferentemente dos linfócitos Th1 e Th2, células Th17 e sua respectiva citocina IL-17 são encontradas nos tecidos intestinais tanto de pacientes com CD como com UC (GALVEZ, 2014). Células Th17 são diferenciadas pela ação conjunta de IL-1ß, IL-6 e fator de crescimento e transformação (TGF - Transforming growth factor) $\beta$ (VELDHOEN et al., 2006), que induzirão ao aumento da expressão do fator de transcrição do Receptor Órfão Relacionado ao Receptor de Ácido Retinoico yt (RORyt) e de receptores de IL-23 (IL-23R) (CHEN, Z.; O'SHEA, 2008). As células Th17 sintetizam citocinas como IL-17A, IL-17F, IL-21 e IL-22 e amplificam suas atividades por estimulação de IL-23 e IL-21 (LIANG et al., 2006; NURIEVA et al., 2007). IL-23 e IL-17 estão aumentadas na DIl e em modelos de colite experimental (FUJINO et al., 2003; LIU, Z. et al., 2011; YEN et al., 2006), além do que camundongos deficientes em IL-17 ou IL-21 desenvolvem colite mais branda quando 
comparados a animais saudáveis (FINA et al., 2008; ITO et al., 2008). Ainda, a estimulação de receptores de IL-23 aumenta a atividade inflamatória de células T efetoras e diminui a diferenciação de células Treg FoxP3+ (AHERN et al., 2010). O balanço entre células Th17 e células Treg é finamente regulado no organismo e alterações nessa relação podem levar à inflamação e doenças autoimunes, tais como as DII (ABRAHAM; CHO, 2009).

Em geral, doenças autoimunes e inflamatórias crônicas têm sido relacionadas a defeitos de tolerância devido a uma diminuição no número e/ou na função de células Treg (LONG; BUCKNER, 2011). Células Treg são constantemente descritas como $\mathrm{CD}^{+}{ }^{+} \mathrm{CD} 25^{\text {high }} \mathrm{FoxP}^{+}$, por expressarem receptores CD4, CD25 (cadeia $\alpha$ do receptor de IL-2) e o fator de transcrição forkhead box P3 (FoxP3) (FONTENOT et al., 2005). Apesar de apresentarem marcadores distintos de outras subpopulações de células $T$, tem sido descrito que os mesmos não são suficientes para completa caracterização das células Treg, propondose ainda a identificação do antígeno de linfócito T citotóxico 4 (CTLA-4 - cytotoxic T lymphocyte antigen) (READ; MALMSTROM; POWRIE, 2000; TAKAHASHI et al., 2000), do receptor de TNF induzido por glicocorticoide (GITR - glucocorticoid-induced TNF receptors family) (MCHUGH et al., 2002), da proteína de morte celular programada 1 (PD-1 Programmed death 1) (RAIMONDI et al., 2006) e baixa expressão do receptor de IL-7 (CD127) (LIU, W. et al., 2006; SEDDIKI et al., 2006), dentre outros. Naturalmente, o papel dessas células é inibir a ativação e proliferação de células efetoras e autorreativas, por exemplo, por meio da produção de citocinas anti-inflamatórias (IL-10 e TGF- $\beta$ ), por apoptose (mediada por granzimas e perforinas ou por privação de citocinas que atuam na manutenção e sobrevivência de células T) e/ou por modulação do estado de ativação de DCs (VIGNALI; COLLISON; WORKMAN, 2008). Sabe-se que, em ambas CD e UC, células Treg estão diminuídas na periferia e aumentadas no tecido linfoide da mucosa, onde mesmo em grande quantidade não conseguem conter as desordens inflamatórias locais (BEGUE et al., 2011; YU et al., 2007). Estes dados sugerem que não apenas o número, mas também a função dessa população celular é essencial para a regulação das respostas inflamatórias crônicas exacerbadas, como aquelas presentes na DII. 


\subsection{Tratamento}

A terapia para DII é um desafio para os profissionais da saúde, uma vez que não existe um alvo específico para se combater a doença. Desse modo, os diferentes tratamentos empregados na atualidade visam atenuar a resposta inflamatória do organismo, prolongar os períodos de remissão clínica e tratar as complicações da doença. Além disso, nenhum medicamento consegue realizar essas tarefas de modo totalmente efetivo e confiável e o êxito da terapia pode ser limitado e imprevisível (MOWAT et al., 2011; SALES-CAMPOS et al., 2015).

Classicamente, o tratamento da DIl tem sido baseado na utilização de aminossalicilatos, antagonistas do ácido fólico, glicocorticoides (GCs), tiopurinas, inibidores da calcineurina, antibióticos/probióticos e agentes biológicos (NAKASE; YOSHINO; MATSUURA, 2014; SALES-CAMPOS et al., 2015). Terapias celulares envolvendo transplantes autólogos e/ou alogênicos de células-tronco hematopoiéticas ou células-tronco mesenquimais também têm sido estudadas com resultados altamente promissores (MARTINEZ-MONTIEL MDEL; GOMEZ-GOMEZ; FLORES, 2014). A escolha do tratamento depende do balanço entre a eficácia e os efeitos adversos do medicamento, da resposta do paciente à terapia anterior, da frequência de recidivas, extensão e gravidade da doença e da presença de manifestações extraintestinais (SALES-CAMPOS et al., 2015).

Os medicamentos usados na DII apresentam diversas limitações, dentre as quais um início de ação lento, elevada taxa de resposta incompleta e consideráveis efeitos adversos (RODRIGUEZ-MORANTA et al., 2007). Existe também a necessidade de altos investimentos no que se refere ao uso desses medicamentos, principalmente com as terapias biológicas, que se somam aos exorbitantes dispêndios com internações e cirurgias (ODES, 2008).

No que diz respeito ao tratamento cirúrgico, sabe-se que um alto número de pacientes com DII pode necessitar desse tipo de intervenção, às vezes até repetidamente (MOWAT et al., 2011). Além disso, com o passar do tempo, recidivas clínicas ocorrem em cerca de metade 
dos pacientes submetidos à cirurgia e esse número pode aumentar para 90\% quando se fala em recidivas endoscópicas (RODRIGUEZ-MORANTA et al., 2007).

Considerando a terapia farmacológica, os GCs normalmente são utilizados como a primeira linha de tratamento não somente para as DII, mas para uma grande quantidade de doenças autoimunes, alérgicas e linfoproliferativas (GENSLER, 2013; KOZUCH; HANAUER, 2008). Entretanto, além dos efeitos adversos significativos encontrados com o uso contínuo destas drogas, após 1 ano de tratamento, 55\% e 43\% dos pacientes pediátricos com CD e UC, respectivamente, tornam-se dependentes dos GCs ou necessitam de intervenção cirúrgica (TUNG et al., 2006). Nos adultos acometidos pela CD, $20 \%$ são refratários ao tratamento e $36 \%$ tornam-se dependentes, independentemente da gravidade da doença (DE IUDICIBUS et al., 2011).

\subsubsection{Glicocorticoides}

Os GCs são uma classe de hormônios esteroidais que contêm 21 carbonos em sua estrutura. Eles possuem a capacidade de se difundirem livremente pela membrana plasmática e de se ligarem ao respectivo receptor citoplasmático (R-GCs). Os R-GCs são formados por um complexo multiprotéico, composto por chaperonas e imunofilinas, e estão ubiquamente distribuídos nas células de animais vertebrados (LOWENBERG et al., 2007; STOLTE et al., 2006). Os GCs possuem diversos mecanismos de ação, genômicos e não-genômicos, mas basicamente atuam como moduladores transcricionais, interagindo direta ou indiretamente com o DNA, diminuindo e aumentando a expressão de genes pró- e anti-inflamatórios, respectivamente, e, assim, modificando o funcionamento celular, principalmente das células do sistema imune (LOWENBERG et al., 2007; RHEN; CIDLOWSKI, 2005). Como resultado, um grande número de citocinas pró-inflamatórias (por exemplo, IL-1 $\beta$, TNF, IL-6, IL-8) é fortemente suprimido, enquanto que citocinas e outras moléculas anti-inflamatórias (IL-10, TGF- $\beta$, IL-10R) são produzidas (FANTUZZI; GHEZZI, 1993; GALON et al., 2002). Os GCs 
sintéticos utilizados nos tratamentos das diversas doenças de caráter inflamatório possuem basicamente os mesmos mecanismos de ação que os endógenos.

Além de exercerem inúmeros efeitos sobre o espectro de citocinas e sobre o sistema imune inato (tais como eosinófilos, basófilos e macrófagos) (SCHLEIMER; BOCHNER, 1994; VAN DER GOES et al., 2000; YOSHIMURA et al., 2001), os GCs também promovem a polarização de células T virgens (Th0 ou T naive) para um fenótipo predominantemente Th2, ao mesmo tempo em que induzem DCs para um fenótipo imaturo tolerogênico (DE JONG et al., 1999). Ainda, ambos os efeitos podem ser, em parte, responsáveis pela indução de células Treg pelos GCs (BARRAT et al., 2002).

Há alguns anos, uma conexão entre GCs e células T de fenótipo supressor foi inicialmente demonstrada in vitro (HIRSCHBERG; RANDAZZO; HIRSCHBERG, 1980; IKEDA et al., 1988), mas posteriormente também foi mostrada in vivo, cujo o tratamento com esteroides induziu o aumento na circulação de células Treg FoxP3 ${ }^{+}$em pacientes asmáticos e a melhora da função dessa subpopulação em pacientes com doença de Graves (HU et al., 2012; KARAGIANNIDIS et al., 2004). No entanto, esta correlação positiva entre o tratamento com GCs e o número/função de células Treg no sangue periférico é ainda controversa clinicamente e experimentalmente em diversas doenças autoimunes (CHEN, X. et al., 2004; KRAAIJ et al., 2011; SBIERA et al., 2011; STOCK et al., 2005; XYSTRAKIS et al., 2006). De modo importante, Prado e colaboradores também constataram que os GCs podem aumentar a expressão de FoxP3 em células Treg, mas isso não leva necessariamente ao aumento da atividade supressora dessas células (PRADO et al., 2011).

Atualmente existem múltiplos GCs sintéticos disponíveis para uso clínico (por exemplo, Prednisona, Prednisolona, Cortisona, Hidrocortisona, Dexametasona - DX -, Betametasona, Budesonida) e podem ser encontrados sob diversas formulações farmacêuticas (comprimido, cápsula, injetável, pomada, supositório, enema) (MOWAT et al., 2011). Esses medicamentos diferenciam-se basicamente pelo tempo de atividade biológica, pela potência anti-inflamatória relativa e pela potência mineralocorticoide relativa (LONGUI, 2007). O risco de toxicidade com o uso prolongado de GCs é alto e está diretamente relacionada ao tempo de uso, dose, 
retirada do tratamento e via de administração (MOGHADAM-KIA; WERTH, 2010; SCHACKE; DOCKE; ASADULLAH, 2002). Após pequenos períodos de tratamento e/ou uso de doses supra-fisiológicas, os principais efeitos adversos dos GCs são face de lua cheia, acne, infecções, equimoses, atrofia cutânea, edemas, distúrbios do sono e hirsutismo. Já o uso prolongado de esteroides e/ou interrupção abrupta do tratamento pode levar a efeitos mais graves, tais como hipertensão, diabetes mellitus, osteonecrose, osteoporose, miopatia, psicose, catarata, glaucoma, insuficiência adrenal aguda, síndrome de retirada, mialgias, artralgias ou pressão intracraniana aumentada (CURTIS et al., 2006; HUSCHER et al., 2009; LONGUI, 2007; MOGHADAM-KIA; WERTH, 2010; MOWAT et al., 2011; SCHACKE et al., 2002). Esses efeitos são, na medida do possível, minimizados através de estratégias preventivas e de monitorização, sendo que $50 \%$ dos pacientes adultos com DII não relatam efeitos adversos com uso da droga (MOWAT et al., 2011).

GCs são utilizados para tratar CD e UC leves a moderadas (KONDAMUDI et al., 2013). Quanto à eficácia na DII, o uso de prednisolona (iniciando em 40mg/dia) induz remissão em $77 \%$ dos pacientes com UC após 2 semanas, enquanto $92 \%$ dos pacientes com CD com uso de prednisona (1mg/kg/dia) entram em remissão após 7 semanas (MOWAT et al., 2011). Entretanto, após 1 ano de tratamento apenas 44\% dos pacientes continuam responsivos aos GCs, enquanto que os restantes tornam-se refratários ou dependentes dos esteroides, como discutido anteriormente.

\subsection{Estatinas}

Estatinas são as drogas mais efetivas na diminuição dos níveis séricos de colesterol para prevenir ou tratar doenças ateroscleróticas e coronarianas (STONE et al., 2014; TONELLI et al., 2011). Elas atuam através da inibição seletiva da enzima 3-hidróxi-3metilglutaril coenzima A (HMG-CoA) redutase que reduz moléculas de HMG-CoA à mevalonato, um dos intermediários na síntese do colesterol realizada principalmente por hepatócitos (SIRTORI, 2014; STANCU; SIMA, 2001). A inibição da produção do colesterol endógeno resulta no aumento da expressão dos receptores hepáticos de lipoproteínas de 
baixa densidade (R-LDL - low-density lipoprotein), que são responsáveis pela depuração da circulação de colesterol de baixa densidade (LDL-C), e também pela redução na secreção hepática de partículas de lipoproteínas de muito baixa densidade (VLDL - very low-density lipoprotein) (AGUILAR-SALINAS; BARRETT; SCHONFELD, 1998; SIRTORI, 2014). Ainda, mecanismos paralelos contribuem para os efeitos cardioprotetores relacionados às drogas, como o aumento da expressão e da ativação de receptores ativados por proliferadores de peroxissomo (PPAR - peroxisome proliferator-activated receptor) a e $\mathrm{\gamma}$, que estão envolvidos, dentre outras funções, com o metabolismo de ácidos graxos (DESVERGNE; WAHLI, 1999; ROGLANS et al., 2002; YANO et al., 2007).

Atualmente, as estatinas têm sido também empregadas como agentes terapêuticos em outros tipos de doenças que não estão diretamente relacionadas à hipercolesterolemia, tais como doenças autoimunes, inflamatórias, neurológicas, renais, ósseas e até câncer (GOMEZ et al., 2014; LIU, X. et al., 2012; LOPEZ-PEDRERA et al., 2012; TU et al., 2012; WOOD; MUPSILONLLER; ECKERT, 2014; ZHANG et al., 2014). Estes “efeitos pleiotrópicos” das estatinas compreendem atividades essencialmente anti-inflamatórias, mas também imunomoduladoras, antioxidantes, vasodilatadoras, antitrombóticas e osteomoduladoras e parecem ser independentes do colesterol (DE LOECKER; PREISER, 2012; GROVER et al., 2013; ZHOU; LIAO, 2010).

Durante a via do mevalonato ocorre a síntese de diversos intermediários lipídicos, entre eles os isoprenoides, que sofrem a ação de diversas enzimas até que o produto final seja formado, o colesterol (BUHAESCU; IZZEDINE, 2007). Estes isoprenoides (por exemplo, isopentil-pirofosfato, geranil-pirofosfato, farnesil-pirofosfato, geranil-geranil-pirofosfato) atuam principalmente como anexos lipídicos de proteínas em modificações pós-traducionais por um processo conhecido como prenilação, influenciando a atividade destas macromoléculas (BUHAESCU; IZZEDINE, 2007; WANG; LIU; LIAO, 2008). A inibição da síntese de isoprenoides tem sido apontada como principal mecanismo dos efeitos anti-inflamatórios das estatinas, entretanto, não é exclusivo (BU; GRIFFIN; LICHTMAN, 2011). 
Ras, Rho e Rac são exemplos de uma família de pequenas proteínas ligadoras de trifosfato de guanosina (GTPases) que contém unidades isoprenoides em suas estruturas e são conhecidas como "interruptores celulares", uma vez que executam diversas funções intracelulares altamente relevantes, tais como tráfego, ciclo, diferenciação, movimento e sinalização celular (BUSTELO; SAUZEAU; BERENJENO, 2007; HEIDER et al., 2010). Estas proteínas têm sido relacionadas com os feitos pleiotrópicos das estatinas. Alterações no funcionamento da proteína Rho, por exemplo, parece aumentar a expressão das enzimas produtoras de óxido nítrico (NOS - nitric oxide synthase) da isoforma endotelial (eNOS endothelial NOS) e, consequentemente, aumentar a síntese de NO, levando à melhora das funções das células endoteliais (LAUFS et al., 1998; LAUFS; LIAO, 1998). Além disso, o uso de estatinas diminui a expressão do complexo principal de histocompatibilidade do tipo II (MHC-II - major histocompatibility complex) em APCs, prejudicando não apenas o processamento e a apresentação de antígenos, mas também a ativação de células T CD4+ (GHITTONI et al., 2006).

Ainda, as drogas hipocolesterolemiantes exercem ações anti-inflamatórias diminuindo os níveis de mediadores inflamatórios como a proteína-c reativa, IL-1 $\beta$, IL-6 e TNF (ASCER et al., 2004) e de moléculas de adesão, com consequente comprometimento na migração de leucócitos para os tecidos inflamados (ASCER et al., 2004; WEITZ-SCHMIDT et al., 2001).

As estatinas também parecem promover a polarização de células T naive para o perfil Th2 em detrimento com o perfil Th1 in vivo e in vitro, modulando os níveis circulantes das respectivas citocinas produzidas (HAKAMADA-TAGUCHI et al., 2003; YOUSSEF et al., 2002). Ainda, os inibidores da HMG-Coa redutase elevam a geração de células Treg FoxP3+ in vivo e in vivo (MAUSNER-FAINBERG et al., 2008; MIRA et al., 2008), provavelmente por aumentar a síntese de TGF- $\beta$ e IL-10 e da quimiocina CCL1 (MENG et al., 2012; MIRA et al., 2008), além de diminuir a diferenciação de células Th17 (KAGAMI et al., 2009).

As estatinas comercialmente disponíveis (sinvastatina, fluvastatina, atorvastatina ATO, rosuvastatina, pravastatina, lovastatina) diferem entre si pela lipofilicidade, meia-vida e potência e, como qualquer outro medicamento, podem causar efeitos adversos: miopatia, 
rabdomiólise, nefrotoxicidade, hepatotoxicidade, diabetes mellitus, manifestações neurológicas e pulmonares (GROVER; LUTHRA; MAROO, 2014). Entretanto, as estatinas são consideradas drogas seguras e apenas uma pequena fração de usuários apresentam problemas relacionados ao uso do medicamento (MAJI et al., 2013; NACI; BRUGTS; ADES, 2013; PFEFFER et al., 2002).

O uso de estatinas na DII tem sido consideravelmente avaliado nos últimos anos. Diversos estudos utilizando modelos experimentais de DII demonstram que essas drogas podem atenuar a colite (AKTUNC et al., 2011; KANAGARAJAN et al., 2008; LEE, J. Y. et al., 2007; SASAKI et al., 2003; SUZUKI et al., 2006) e até mesmo convalescer animais com câncer associado a UC (CHO et al., 2008; SUZUKI et al., 2006). Em humanos, estes estudos ainda são escassos, mas Grip e colaboradores observaram que após o uso de ATO em pacientes com CD houve redução na atividade da doença e alta taxa de remissão nos pacientes tratados (GRIP; JANCIAUSKIENE; BREDBERG, 2008). Diversos mecanismos têm sido sugeridos para as melhoras observadas na DII após tratamento com estatinas: diminuição da migração de monócitos para tecidos inflamatórios via diminuição da síntese de TNF e proteína quimiotática de monócitos (MCP-1 - monocyte chemoattractant protein 1) (GRIP; JANCIAUSKIENE; LINDGREN, 2004); polarização de células T para o perfil Th2 e diminuição de células Th1 e Th17 (AKTUNC et al., 2011); aumento da expressão e da função de eNOS (SASAKI et al., 2003); inibição da via NF-kB em IEC (LEE, J. Y. et al., 2007); redução dos níveis de CXCL10, quimiocina que participa no recrutamento de células T (GRIP; JANCIAUSKIENE, 2009); indução de apoptose e supressão da angiogênese em tumores associados à colite (CHO et al., 2008).

\subsection{Associação de glicocorticoides e estatinas}

O uso concomitante de estatinas e GCs também tem sido uma nova estratégia empregada em algumas doenças inflamatórias. Essa associação parece aumentar tanto a proporção de células Treg/Th17, como a síntese de indoleamina 2,3-dioxigenase (IDO; enzima associada com o catabolismo do triptofano e com propriedades imunomoduladoras) 
por macrófagos de pacientes asmáticos, controlando a inflamação das vias aéreas de modo mais eficaz que a simples utilização de GCs (MANEECHOTESUWAN et al., 2010; MANEECHOTESUWAN et al., 2013). Um estudo retrospectivo mostrou que o uso associado de estatinas e esteroides no tratamento de pacientes com doença pulmonar obstrutiva crônica (DPOC) resultou em melhor sobrevida dos doentes (SOYSETH et al., 2007). Entretanto, a adição de estatinas em tratamentos com corticosteroides não causa alteração no curso de certas condições clínicas, tais como a osteonecrose causada pelo uso de esteroides em pacientes transplantados e a arterite temporal (AJMAL et al., 2009; GARCIA-MARTINEZ et al., 2004).

$\mathrm{Na}$ DII, Crockett e colaboradores observaram, em estudo retrospectivo, que o uso sincrônico de estatinas e GCs causou a diminuição das doses de GCs necessárias para o tratamento de pacientes com DII e, dentre os tipos de estatinas avaliadas, a ATO apresentou os efeitos protetores mais pronunciados (CROCKETT et al., 2012). Entretanto, apesar de já existirem indicativos de melhora de pacientes com DIl pela utilização combinada de GCs e estatinas, ainda há escassez de dados que mostrem as alterações causadas no sistema imunológico, assim como seu papel na modulação das subpopulações de células T efetoras e reguladoras, cujo balanço define o curso da doença em pacientes ou modelos experimentais de DII. 
2. objetivos 


\section{OBJETIVO}

Investigar os efeitos imunomoduladores da associação de estatinas e glicocorticoides na inflamação intestinal induzida experimentalmente.

\subsection{Objetivos específicos}

- Avaliar o efeito da combinação de glicocorticoides e estatinas no curso clínico da colite experimental;

- Verificar as alterações macroscópicas, microscópicas e imunológicas no sítio inflamatório induzidas pela terapia sistêmica com glicocorticoides e estatinas;

- Avaliar o potencial modulador da terapia com glicocorticoides e estatinas in vitro e ex vivo. 
3.MATERIALEMÉTODOS 


\section{MATERIAL E MÉTODOS}

\subsection{Animais}

Camundongos do tipo selvagem (WT - wild type) da linhagem C57BL/6, machos, entre 6-8 semanas de vida e pesando entre $20-25 \mathrm{~g}$ foram obtidos junto ao Biotério Central da Universidade de São Paulo Campus de Ribeirão Preto (USP/RP). Também foram utilizados camundongos WT da linhagem C57BL/6 e camundongos transgênicos que expressam proteína fluorescente verde (GFP - green fluorescent protein) sob controle do promotor FoxP3 (FoxP3-GFP+) de background C57BL/6, fêmeas, com mesmo peso e idade descritos. Camundongos FoxP3-GFP+ foram gentilmente cedidos pelo Prof. Dr. Fernando de Queiroz Cunha (FMRP/USP). Os animais foram ambientados e mantidos em gaiolas de microisoladores autoclavados (5 animais por gaiola) no Biotério do Laboratório de Imunoendocrinologia e Regulação (LIR) da Faculdade de Ciências Farmacêuticas de Ribeirão Preto (FCFRP/USP) em condições livre de patógenos específicos (SPF - specific pathogenfree), com fotoperíodo de $12 / 12$ horas, temperatura de $25 \pm 2^{\circ} \mathrm{C}$ e recebendo água e ração (Nuvilab CR-1 Autoclavável - Quimtia, Colombo, PR, Brasil) esterilizados ad libitum. Todos os procedimentos foram conduzidos de acordo com os princípios éticos propostos pelo Colégio Brasileiro de Experimentação Animal (COBEA) e certificados pelo protocolo nº 10.1.499.53.8 pela Comissão de Ética no Uso de Animais (CEUA/USP/RP; anexo I).

\subsection{Colite experimental induzida por dextran sulfato de sódio}

A inflamação intestinal foi induzida pelo oferecimento exclusivo e contínuo ad libitum de água contendo dextran sulfato de sódio (DSS) 3\% (MP Biomedicals, Santa Ana, CA, EUA), que foi disponibilizada aos camundongos por até 18 dias consecutivos nos experimentos de sobrevida (incluindo as avaliações de dose x resposta e de via de administração) ou por 6 dias consecutivos para os experimentos de coleta de amostras. 


\subsection{Tratamentos in vivo e in vitro}

Para os experimentos propostos foram utilizadas as drogas dexametasona (DX; Decadron ${ }^{\circledR}$ - Aché, Guarulhos, SP, Brasil) e atorvastatina (ATO; Lipitor® - Pfizer, Guarulhos, SP, Brasil) como representantes das classes farmacológicas dos GCs e estatinas, respectivamente. Para os experimentos in vivo foram realizados testes para avaliar a melhor via de administração e/ou dose das respectivas drogas: DX foi avaliada na dose de $1 \mathrm{mg} / \mathrm{kg} / \mathrm{dia}$, enquanto que a ATO foi avaliada nas concentrações de 5,10 e $20 \mathrm{mg} / \mathrm{kg} / \mathrm{dia}$, ambas por via oral (v.o.) ou intraperitoneal (i.p.). Para o teste de v.o. foram utilizados Decadron $\AA$ e Lipitor $\AA$ na forma farmacêutica de comprimido, os quais foram deixados dissolver em salina estéril até a formação da suspensão; a aplicação foi realizada com auxílio de seringa e agulha de gavagem. Decadron® injetável e Lipitor® comprimido também foram diluídos e dissolvidos, respectivamente, em salina estéril para os tratamentos i.p. e a aplicação foi realizada com auxílio de seringa e agulha 26G. Os critérios utilizados para a escolha da melhor dose e via de administração das drogas foram a sobrevida dos animais e as análises dos parâmetros clínicos e de perda de peso, que serão descritos posteriormente.

Após a estipulação das melhores doses e vias de administração de DX e/ou ATO, os camundongos foram tratados com a(s) droga(s) ou o veículo (salina) seguindo dois esquemas terapêuticos: (1) tratamento contínuo e diário a contar do dia do surgimento dos sinais clínicos da colite experimental (geralmente 3 dias após o início da indução da doença) para o experimento de sobrevida (Figura 1A) ou (2) tratamento diário por 3 dias consecutivos, também a partir do terceiro dia de exposição dos animais ao DSS, para os experimentos de coleta de material biológico (Figura 1B). As drogas foram administradas em volume de $100 \mu \mathrm{L} / a n i m a l$ para as drogas isoladas e $200 \mu \mathrm{L} /$ animal para as drogas combinadas; animais controle receberam $200 \mu \mathrm{L} / a n i m a l$ do veículo (Figura 1C). Os camundongos tratados com as duas classes de fármacos receberam as mesmas doses administradas isoladamente.

Desse modo, foram estabelecidos os seguintes grupos experimentais, doses e via de administração das drogas: grupo "controle saudável” $(n=5)$, animais controles, sem indução de DII, tratados com o veículo da droga (salina) por v.o.; grupo "DSS" $(n=5)$, animais com 
DII induzida por DSS, tratados com o veículo da droga por v.o.; grupo “DX” $(n=5)$, camundongos com DII tratados com o glicocorticoide dexametasona - DX (1mg/kg/dia) por v.o.; grupo “ATO” $(n=5)$, animais com DII tratados com atorvastatina - ATO $(10 \mathrm{mg} / \mathrm{kg} / \mathrm{dia})$ por v.o.; grupo “DX + ATO” $(n=5)$, animais com DIl tratados com DX (1mg/kg/dia) e ATO (10mg/kg/dia), ambos por v.o.

A.

$\mathrm{H}_{2} \mathrm{O}$ ou DSS $3 \%$

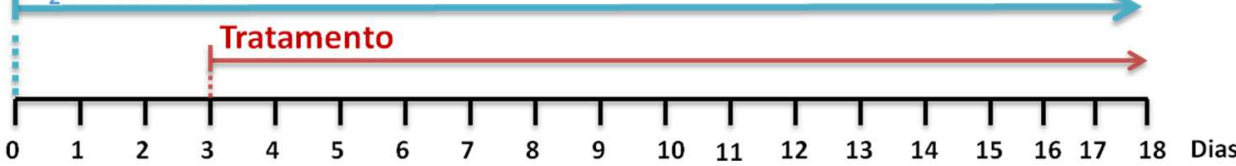

Sinais

clínicos

B.

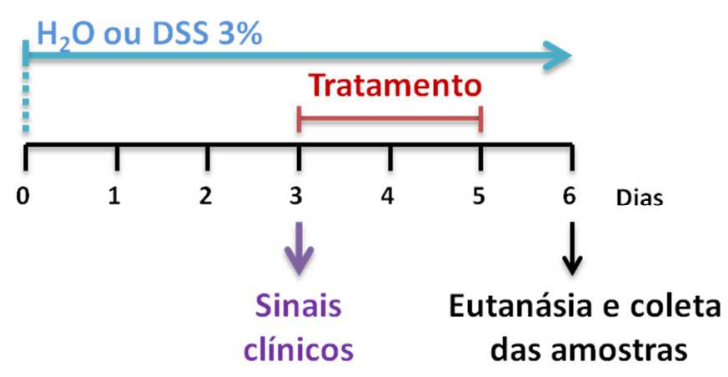

C.

\begin{tabular}{ccc}
\hline Tratamentos & $\begin{array}{c}\text { Doses } \\
\text { escolhidas }\end{array}$ & $\begin{array}{c}\text { Volume } \\
\text { administrado }\end{array}$ \\
\hline $\begin{array}{c}\text { Veículo } \\
\text { (Salina) }\end{array}$ & - & $200 \mu \mathrm{L}$ \\
DX & $1 \mathrm{mg} / \mathrm{kg} / \mathrm{dia}$ & $100 \mu \mathrm{L}$ \\
ATO & $10 \mathrm{mg} / \mathrm{kg} / \mathrm{dia}$ & $100 \mu \mathrm{L}$ \\
DX + & $1 \mathrm{mg} / \mathrm{kg} / \mathrm{dia}$ & $200 \mu \mathrm{L}$ \\
ATO & $10 \mathrm{mg} / \mathrm{kg} / \mathrm{dia}$ & \\
\hline
\end{tabular}

Figura 1. Esquema do delineamento experimental para o estudo de associações de drogas in vivo. A-B. Camundongos C57BL/6 foram submetidos à colite experimental pelo oferecimento ad libitum e contínuo de água $\left(\mathrm{H}_{2} \mathrm{O}\right)$ contendo dextran sulfato de sódio (DSS) $3 \%$ por até 18 dias para os experimentos de sobrevida (A) ou por 6 dias para o experimento de coleta de amostras (sangue, baço, linfonodos mesentéricos e cólon) (B). C. Os tratamentos com o veículo das drogas (salina), dexametasona (DX) e/ou atorvastatina (ATO) foram realizados diariamente e em dose única nos volumes e doses apresentados na tabela a partir do surgimento dos primeiros sinais clínicos da doença (3 dias após exposição ao DSS). Camundongos tratados com a associação das drogas receberam as mesmas doses utilizadas nos tratamentos isolados.

Considerando os experimentos para a coleta de material, os animais foram devidamente eutanasiados com uso de dióxido de carbono $\left(\mathrm{CO}_{2}\right)$ no $6^{\circ}$ dia de exposição à água contendo DSS. Em seguida, amostras de sangue (total e soro), intestino (cólon), baço e linfonodos mesentéricos (LNM) foram coletadas para as análises posteriores.

Para os tratamentos in vitro de células do baço de camundongos C57BL/6, Decadron $\AA$ injetável e Lipitor $\AA^{\circledR}$ comprimido foram usados nas concentrações de 0,$1 ; 1$ e $5 \mu \mathrm{M}$ 
ou 5 e $10 \mu \mathrm{M}$, respectivamente, sempre utilizando salina estéril como diluente/dispergente.

\subsection{Parâmetros avaliados na colite experimental induzida por dextran sulfato de sódio}

3.4.1. Consumo de dextran sulfato e sódio, aferição do peso corporal e escore clínico

Os camundongos submetidos à DII pela exposição contínua ao DSS foram diariamente avaliados quanto às variações de peso corporal, de consumo de água/DSS e de ração. Os animais foram pesados diariamente e a variação da massa corporal foi determinada pela comparação com o peso do animal no dia do início do experimento (dia 0). As quantidades de ração e de DSS/água consumidas foram calculadas pela determinação diária das massas ou volumes, respectivamente, presentes nos recipientes e pela diferença em relação ao dia anterior. Esses valores foram divididos pela quantidade de animais presentes na caixa para obtenção do valor médio de consumo por animal.

Ainda, os sinais clínicos da doença também foram avaliados e incluíram: perda de peso ( $\geq 5 \%$ do peso corporal comparado ao dia anterior), constatação da região perianal umedecida, presença de diarreia, sangue nas fezes ou na região perianal, hiporreatividade e/ou piloereção. Para esta avaliação clínica, foi utilizado um critério de pontuação, no qual cada sinal apresentado pelo animal correspondeu a 1 ponto, exceto a perda de peso corporal $\geq 10 \%$ que correspondeu a 2 pontos (Tabela 1). A somatória dos pontos determinou o escore clínico da doença. 
Tabela 1 - Sinais clínicos avaliados na doença inflamatória intestinal induzida por dextran sulfato de sódio para cálculo do escore clínico da doença

\begin{tabular}{cc|}
\hline Parâmetros observados & Pontuação \\
\hline Normal & 0 \\
\hline Região perianal umedecida & 1 \\
Diarreia & 1 \\
\hline Sangue nas fezes ou região perianal & 1 \\
Perda de peso $(\mathbf{2 5 \%} \mathbf{e}<\mathbf{1 0} \%)^{*}$ & 1 \\
Perda de peso $(\mathbf{1 0} \%)^{*}$ & 2 \\
Hipoatividade & 1 \\
Piloereção & 1 \\
\hline${ }^{*}$ Perda de peso em relação ao dia anterior
\end{tabular}

Embora possa haver alguma diferença no consumo individual de água/DSS dentre os camundongos alocados na mesma gaiola, no terceiro dia de indução de colite praticamente todos os animais apresentaram pelo menos um dos sinais clínicos citados anteriormente. Nos casos em que houve diferenças relevantes de apresentação clínica da doença entre os diversos grupos, os camundongos com colite foram realocados de forma que os grupos doentes tratados ou não tratados apresentassem a maior homogeneidade possível antes do início das terapias.

Os camundongos estudados nos experimentos de sobrevida também foram avaliados utilizando-se os mesmos critérios descritos anteriormente, incluindo consumo de água/DSS e ração, variação de peso e sinais clínicos da colite experimental induzida por DSS. Além disso, para avaliar o curso clínico da doença, a soma do escore clínico obtido em todos os dias de experimento foi dividida pelo número de dias de sobrevivência para cada animal e chamada "escore clínico relativo". 


\subsubsection{Escore pós-morte e escore acumulado}

Após a eutanásia dos animais no $6^{\circ}$ dia de exposição ao DSS, o intestino grosso foi coletado e dissecado longitudinalmente para avaliação do conteúdo intestinal. A análise foi realizada pela constatação de diarreia ou sangue localizados em algum segmento do cólon (diarreia local ou sangue local) ou pela presença dos mesmos sinais em mais de um segmento (diarreia difusa ou sangue difuso). A consistência das fezes localizadas no cólon ascendente do intestino dos camundongos não foi incluída na análise, uma vez que nessa região as fezes são sempre fisiologicamente liquefeitas. A presença ou ausência de estenose também foi verificada. Do mesmo modo que o escore clínico, esta análise utilizou-se de um critério de pontuação, no qual cada sinal local correspondeu a 1 ponto, enquanto que os sinais difusos e a presença de estenose corresponderam a 2 pontos (Tabela 2). A somatória dos pontos determinou o escore pós-morte da doença.

Tabela 2 - Sinais clínicos avaliados na doença inflamatória intestinal induzida por dextran sulfato de sódio para cálculo do escore pós-morte da doença

\begin{tabular}{|cc|}
\hline Parâmetros observados & Pontuação \\
\hline Normal & 0 \\
\hline Diarreia localizada & 1 \\
\hline Diarreia difusa & 2 \\
\hline Sangue localizado & 1 \\
\hline Sangue difuso & 2 \\
\hline Estenose & 2 \\
\hline
\end{tabular}

O escore clínico no dia da eutanásia ( $6^{\circ}$ dia após o início da colite experimental) somado ao escore pós-morte também foi avaliado e definido com escore acumulado da doença. 


\subsection{Análise do comprimento do cólon}

Após a coleta do cólon dos camundongos em estudo, os mesmos foram colocados cuidadosamente sobre uma superfície limpa e fotografados com auxílio de câmera fotográfica acoplada a um suporte de altura fixa. As imagens foram calibradas pela presença de uma régua graduada que serviu como escala para as análises. Posteriormente, as imagens de intestino grosso foram avaliadas pelo uso do software ImageJ (National Institutes of Health, Bethesda, Maryland, EUA).

\subsection{Fragmentação do cólon e direcionamento das amostras}

Após análise do comprimento, os cólons dos camundongos foram rapidamente fragmentados em diversos segmentos para a realização dos diferentes ensaios propostos (Figura 2). Cada segmento foi direcionado para um determinado tipo de análise, obedecendo rigorosamente a mesma sequência para cada amostra coletada dos diferentes animais. Os testes incluíram ensaios de mieloperoxidase (MPO)/N-acetilglicosaminidase (NAG), eosinófilo-peroxidase (EPO), PCR em tempo real (qPCR), imunoensaio enzimático (ELISA) e histologia. Os fragmentos de tecidos também foram pesados para posterior correção dos cálculos realizados nas análises.

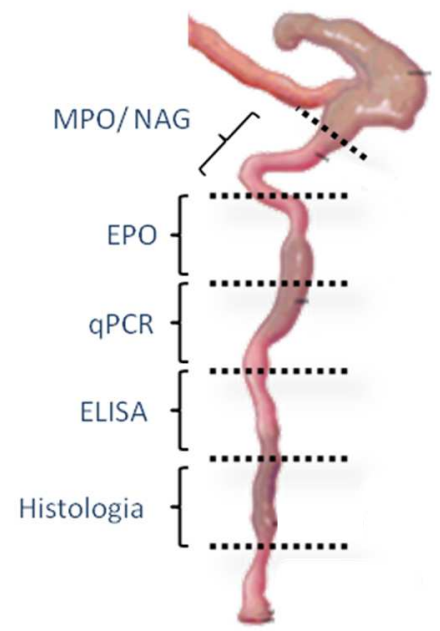

Figura 2. Imagem representativa dos fragmentos de cólon de camundongos C57BL/6 destinados às diferentes análises. MPO: mieloperoxidase; NAG: N-acetilglicosaminidase; EPO: eosinófiloperoxidase; qPCR: reação em cadeia da polimerase em tempo real; ELISA: imunoensaio enzimático. Figura adaptada de Treuting \& Dintzis (TREUTING; DINTZIS, 2012) 


\subsection{Obtenção de soro, contagem total e diferencial de células do sangue periférico}

Após a eutanásia dos animais, o sangue periférico foi coletado para obtenção do soro, para a contagem global de células em hemocitômetro (câmara de Neubauer) com solução de Turk e para o esfregaço sanguíneo. O soro foi obtido pela centrifugação do sangue total a 2000xg, por 10 minutos, após um período de descanso de 30 minutos a temperatura ambiente para permitir a formação do coágulo. Posteriormente, o sobrenadante foi cuidadosamente coletado e armazenado a $-70^{\circ} \mathrm{C}$ para as análises posteriores.

A contagem global de células foi realizada pela diluição de sangue total em solução de Turk na proporção 1:10; todas as células coradas localizadas nos quatro quadrantes externos do retículo do hemocitômetro foram contadas e a concentração foi expressa por $\mathrm{mL}$ de sangue. Já a extensão ou esfregaço sanguíneo foi corado com Panótico Rápido (Laborclin, Pinhais, PR, Brasil), que se utiliza do princípio de coloração hematológica de Romanowsky, e examinado em microscópio (DM750, Leica, Wetzlar, Alemanha) com objetiva de imersão em óleo. O exame foi realizado na parte mais fina da extensão contando-se 50 leucócitos no centro e 50 leucócitos na borda da extensão, totalizando-se assim 100 células. A contagem foi feita anotando-se separadamente cada tipo de leucócito identificado (neutrófilos, linfócitos, monócitos, eosinófilos e/ou basófilos). O número relativo de leucócitos foi determinado de acordo com a frequência (\%) encontrada das respectivas populações celulares. Já a quantidade absoluta foi calculada multiplicando-se a frequência relativa dos leucócitos pelo número total de células obtido na contagem em hemocitômetro; o produto resultante foi dividido por 100 e expresso como número de células por $\mathrm{mm}^{3}$ de sangue.

\subsection{Ensaio para quantificação indireta de neutrófilos, macrófagos e eosinófilos}

Para quantificação indireta da presença de neutrófilos, macrófagos e eosinófilos no cólon inflamado foram realizados testes que determinam a atividade de enzimas características dessas populações celulares, tais como a mieloperoxidase (MPO), Nacetilglicosaminidase (NAG) e eosinófilo-peroxidase (EPO), respectivamente. A extração dessas enzimas foi realizada pela lise das células dos fragmentos de cólon. 
Para as análises de MPO e NAG, os tecidos intestinais previamente coletados e pesados foram triturados em $400 \mu \mathrm{L}$ de tampão fosfato $0,02 \mathrm{M}$, contendo $\mathrm{NaCl} 0,1 \mathrm{M}$ e EDTA $1,015 \mathrm{M}(\mathrm{pH} 4,7)$. $\mathrm{O}$ homogenato foi centrifugado a $600 \mathrm{xg}$ por 15 minutos a $4^{\circ} \mathrm{C}$, o sobrenadante foi aspirado e desprezado com auxílio de uma pipeta. Após, o precipitado foi novamente ressuspenso em $400 \mu \mathrm{L}$ de tampão fosfato $0,02 \mathrm{M}$, contendo $\mathrm{NaCl} 0,1 \mathrm{M}$ e EDTA 1,015M ( $\mathrm{pH} 4,7)$ por agitação em vórtex e, em seguida, adicionado $400 \mu \mathrm{L}$ de $\mathrm{NaCl} 0,2 \%$ gelado, deixando-se incubar por 30 segundos em temperatura ambiente para a lise de hemácias. Posteriormente, adicionou-se $400 \mu \mathrm{L}$ de solução $\mathrm{NaCl} 1,6 \%$ com glicose $5 \%$, gelada, e as amostras foram novamente centrifugadas a $600 \mathrm{xg}$ por 15 minutos a $4^{\circ} \mathrm{C}$. Após desprezar o sobrenadante, o precipitado foi ressuspenso em $200 \mu \mathrm{L}$ de tampão fosfato $0,05 \mathrm{M}$ contendo 0,5\% de brometo de hexadeciltrimetilamônio (HTAB - hexadecyltrimethylammonium bromide; $\mathrm{pH} 5,4)$, por agitação em vórtex. Para lise completa das células remanescentes, as amostras foram então congeladas e descongeladas 3 vezes em ciclos de nitrogênio líquido e banho-maria a $37^{\circ} \mathrm{C}$, respectivamente. Em seguida, as amostras foram centrifugadas a $15000 \times$ g por 15 minutos a $4^{\circ} \mathrm{C}$ e o sobrenadante foi coletado para as dosagens das respectivas enzimas. As atividades de MPO e NAG foram medidas no sobrenadante do extrato celular obtido. Para dosagem de MPO, $50 \mu \mathrm{L}$ da amostra foi incubada com $50 \mu \mathrm{L}$ do reagente substrato TMB (3,3',5,5'-tetrametilbenzidina, BD Bioscience, San Diego, CA, EUA) em placa de 96 poços por 15 minutos a $37^{\circ} \mathrm{C}$ e ao abrigo da luz. A reação foi interrompida com $25 \mu \mathrm{L}$ de $\mathrm{H}_{2} \mathrm{SO}_{4} 2 \mathrm{~N}$ e a leitura feita em espectrofotômetro a 450nm (BioTek ELx808; Thermo Fisher Scientific, Waltham, MA, EUA). Para dosagem de NAG, $25 \mu L$ da amostra foi incubada com $25 \mu \mathrm{L}$ do substrato $p$-nitrofenil-2-acetamida- $\beta$-D-glicopiranosideo $2,24 \mathrm{mM}$

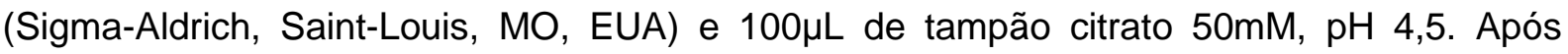
incubação a $37^{\circ} \mathrm{C}$ por 60 minutos, a reação foi interrompida com $100 \mu \mathrm{L}$ de tampão glicina 0,2M, pH 10,4 e a leitura feita em espectrofotômetro a 405nm.

Considerando o ensaio de EPO, os segmentos intestinais destinados à análise foram triturados na presença de $400 \mu \mathrm{L}$ de tampão HBSS (solução salina balanceada de Hanks Hank's balanced salt solution) contendo Ácido N-2-hidroxietilpiperazina-N'-2-etanosulfônico 
(HEPES) 10mM, pH 7,4, e centrifugados a 2000xg por 15 minutos. Após descarte do sobrenadante, o precipitado foi ressuspenso em $1 \mathrm{~mL}$ de PBS $1 \times$ seguido da adição de $3 \mathrm{~mL}$ de água destilada para o choque hipotônico e lise de hemácias, homogeneizado e deixado reagir por 40 segundos. Em seguida, adicionou-se $1 \mathrm{~mL}$ de solução $\mathrm{NaCl} 3,5 \%$ e, após homogeneização em vórtex, adicionou-se $5 \mathrm{~mL}$ de PBS 1x. As amostras foram centrifugadas a $2000 \times$ g, por 10 minutos a $4^{\circ} \mathrm{C}$ e o sobrenadante completamente descartado. O precipitado foi ressuspenso em $200 \mu \mathrm{L}$ de tampão HBSS contendo $14 \mathrm{mM}$ de $\mathrm{HTAB}(\mathrm{pH} 7,4)$ e então congelado e descongelado 3 vezes em ciclos de nitrogênio líquido e banho-maria a $37^{\circ} \mathrm{C}$, respectivamente, para lise completa das células remanescentes. Posteriormente, as amostras foram centrifugadas a $15000 \mathrm{xg}, 10$ minutos a $4^{\circ} \mathrm{C}$ e $50 \mu \mathrm{L}$ do sobrenadante resultante foi colocado para reagir com $50 \mu \mathrm{L}$ do substrato dicloridrato de o-fenilenodiamina (OPD - ophenylenediamine dihydrochloride; Sigma-Aldrich, Saint-Louis, MO, EUA) por 30 minutos a $37^{\circ} \mathrm{C}$ e ao abrigo da luz. Após o período de incubação, a reação foi interrompida com a adição de $25 \mu \mathrm{L} \mathrm{e}_{2} \mathrm{SO}_{4} 2 \mathrm{~N}$ e a leitura feita em espectrofotômetro a $492 \mathrm{~nm}$.

Todos os resultados foram expressos em densidade óptica (DO) corrigidos pelo peso do tecido em gramas $(\mathrm{g})$.

\subsection{Extração de RNA, síntese de cDNA e qPCR}

O RNA foi extraído de fragmentos de cólon de animais C57BL/6 tratados ou não com DX e/ou ATO para determinar a transcrição de genes importantes para a resposta imune por PCR quantitativo em tempo real (qPCR). O RNA total foi extraído por método orgânico utilizando-se TRIzo|® (Invitrogen, Waltham, MA, EUA), seguido por etapas de purificação com uso do kit SV Total RNA Isolation System (Promega, Madison, WI, EUA) de acordo com as instruções dos fabricantes. Após, a quantidade, pureza e qualidade do RNA obtido foram determinadas com o uso de um espectrofotômetro (NanoDrop 1000, Thermo Fisher Scientific, Wilmington, DE, EUA).

O RNA purificado foi utilizado para a confecção do DNA complementar (cDNA complementary DNA) com o sistema de transcrição reversa GoScript ${ }^{T M}$ (Promega, Madison, 
WI, EUA), seguindo as recomendações do fabricante. Resumidamente, $1 \mu \mathrm{g}$ de RNA total foi incubado com $0,5 \mu \mathrm{g}$ de oligo(dT) ${ }_{12}$ e água livre de nuclease em quantidade suficiente para 5uL de volume final de reação. Deixou-se deixado reagir por 5 minutos a $70^{\circ} \mathrm{C}$. Posteriormente, as amostras foram arrefecidas a $4^{\circ} \mathrm{C}$ por 5 minutos e $15 \mu \mathrm{L}$ de uma solução contendo $\mathrm{MgCl}_{2} 3 \mathrm{mM}$, dNTP Mix 0,5mM, $1 \mu \mathrm{L}$ da transcriptase reversa ImProm-IIM, tampão de reação ImProm- II $^{\mathrm{TM}} 1 \mathrm{x}$ e água livre de nuclease em quantidade suficiente para $15 \mu \mathrm{L}$ de

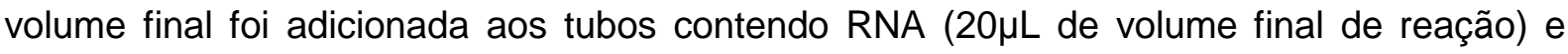
incubados a $25^{\circ} \mathrm{C}$ por 5 minutos, $42^{\circ} \mathrm{C}$ por 60 minutos e $70^{\circ} \mathrm{C}$ por 15 minutos em termociclador (Mastercycler pro®, Eppendorf, Hamburg, Alemanha). Posteriormente, as amostras contendo cDNAs foram diluídas $10 x$ em água livre de nuclease e estocadas a $-20^{\circ} \mathrm{C}$ até a análise.

A expressão quantitativa dos genes das citocinas TNF, IFN- $y$, IL-1ß, IL-4, IL-6, IL-17, IL-23, TGF- $\beta$, dos receptores PPAR- $\alpha$ e y e constitutivo ( $\beta$-actina) foi analisada por meio da reação de qPCR com o sistema de detecção GoTaq® qPCR Master Mix (Promega, Madison, WI, EUA). Cinco microlitros das amostras contendo cDNA foram colocados para reagir em placas apropriadas de 96 poços (MicroAmp Fast Optical 96-well reaction plate - Applied Biosystem, Foster City, CA, EUA) com uma solução contendo GoTaq®, oligonucleotídeos iniciadores (primers) senso e anti-senso (300nM cada) e água livre de nuclease em quantidade suficiente para $10 \mu \mathrm{L}$ de solução $(15 \mu \mathrm{L}$ de volume final de reação). Em seguida, as placas foram cuidadosamente seladas (MicroAmp optical adhesive film - Applied Biosystem, Foster City, CA, EUA), rapidamente centrifugadas e a reação realizada em aparelho StepOnePlus ${ }^{T M}$ (Applied Biosystem, Foster City, CA, EUA), que compreendeu 2 minutos a $50^{\circ} \mathrm{C}, 2$ minutos a $95^{\circ} \mathrm{C}$, seguida por 40 ciclos de 15 segundos a $95^{\circ} \mathrm{C}, 30$ segundos a $58^{\circ} \mathrm{C}$ e 30 segundos a $72^{\circ} \mathrm{C}$, além de um ciclo final com temperatura crescente de 60 a $95^{\circ} \mathrm{C}$ para a obtenção da curva de dissociação. Os oligonucleotídeos utilizados na reação foram: $\beta$ actina 5'-AACGAGCGGTTCCGATG-3'; anti-senso: 5'GGATTCCATACCCAAGAAGGA-3'); TNF (senso: 5'-TGTGCTCAGAGCTTTCAACAA-3'; antisenso: $\quad$ 5'-CTTGATGGTGGTGATGAGA-3'); IFN-ץ (senso: 5'CACACCTGATTACTACCTTC-3'; anti-senso: 5'-GGGTTGTTGACCTCAAAC-3') IL-1ß (senso: 
5'-TGACAGTGATGAGAATGACCTGTTC-3'; anti-senso: 5'-TTGGAAGCAGCCCTTCATCT3'); IL-4 (senso: AAGAGCATCATGCAAATGGA-3'; anti-senso: 5'TTAAAGCATGGTGGCTCAGTAC-3'); IL-6 (senso: 5'-CCCAATTTCCAATGCTCTCC-3'; antisenso: $\quad$ 5'-TGAATTGGATGGTCTTGGTCC-3'); IL-17A (senso: 5'TGCCCTCCACAATGAAAAGA-3'; anti-senso: 5'-AACACGAAGCAGTTTGGGAC-3'); IL-23 (senso: 5'-AATGTGCCCCGTATCCAGTGT-3'; anti-senso: $5^{\prime}-$ GGCTCCCCTTTGAAGATGTCA-3';) TGF- $\beta$ (senso: 5'-TGAACCAAGGAGACGGAATACA-3'; anti-senso: $\quad$ 5'-GGAGTTTGTTATCTTTGCTGTCACA-3'); PPAR- $\alpha \quad$ (senso: 5'TCAATGCCTTAGAACTGGATGA-3'; anti-senso: 5'-CCGATCTCCACAGCAAATTATA-3'); PPAR-y (senso: 5'-TGAGATCATCTACACGATGCTG-3'; $\quad$ antisenso: $\quad$ 5'AGGAACTCCCTGGTCATGAA-3'). Todos os primers foram obtidos da companhia SigmaAldrich (Saint-Louis, MO, EUA), exceto IL-4, IL-6 e IL-23 que foram obtidos junto à companhia Bio Basic (Markham, Ontario, Canadá). As amostras foram analisadas em duplicata e os resultados corrigidos pela $\beta$-actina, para normalizar os níveis de expressão dos genes alvos, e analisados com base no valor de Ct (ciclo limiar - cycle threshold). O resultado foi calculado pela fórmula $\Delta \Delta \mathrm{Ct}=\Delta \mathrm{Ct}$ amostra $-\Delta \mathrm{Ct}$ amostra controle (grupo I - animais controles, sem indução de Dll tratados com o veículo das drogas), onde $\Delta \mathrm{Ct}=\mathrm{Ct}$ gene estudado $-\mathrm{Ct} \beta$ actina. O número de vezes de expressão diferencial do RNA mensageiro (RNAm) comparado com o controle foi definido pela fórmula matemática $2^{-\Delta \Delta \mathrm{Ct}}$, como já bem estabelecido na literatura (LIVAK; SCHMITTGEN, 2001).

\subsection{Análise histológica}

Para avaliar a morfologia e as alterações patológicas no intestino de camundongos com DII tratados com DX e ATO, isoladamente ou em associação, os respectivos fragmentos do cólon coletados no $6^{\circ}$ dia após a indução da colite foram lavados com PBS 1 x para retirada das fezes e fixados em tampão fosfato contendo formol $10 \%$ por 24 horas. Em seguida, os tecidos foram desidratados através de sucessivas incubações com alcoóis etílicos de concentrações crescentes ( $70 \%$ a absoluto), terminando com incubação em uma mistura 
contendo álcool etílico absoluto e xilol em proporção 1:1. Após, os tecidos foram submetidos a 3 incubações sucessivas em xilol e colocados em 2 banhos sucessivos de parafina líquida, antes de serem finalmente incluídos na parafina com auxílio de suportes apropriados. Usandose um micrótomo (RM2125 RTS - Leica, Wetzlar, Alemanha), as secções coronais dos tecidos foram realizadas em espessura de $5 \mu \mathrm{m}$, dispostas em lâminas de microscopia e, posteriormente, incubadas em estufa a $60^{\circ} \mathrm{C}$ para fixação. Em seguida, as lâminas foram lavadas em 2 banhos sucessivos de xilol para retirar o excesso de parafina e reidratadas com concentrações decrescentes de álcool (do absoluto ao 70\%). Os cortes foram então corados com hematoxilina e eosina (H\&E), novamente desidratados com concentrações crescentes de álcool (de $70 \%$ ao absoluto) e diafanizados com xilol. Finalmente, lamínulas foram adicionadas às lâminas com auxílio de Bálsamo do Canadá (Vetec Química, Rio de Janeiro, Brasil). As análises morfométricas foram realizadas em colaboração com o Prof. Dr. Javier Emílio Lazo Chica, patologista (Universidade Federal do Triângulo Mineiro - UFTM), e incluíram a presença e extensão de infiltrados inflamatórios, arquitetura anatômica e espessura da lâmina própria e submucosa. As imagens obtidas foram fotogradas usando-se uma câmera acoplada ao microscópio.

\subsection{Extração de leucócitos dos tecidos}

Para caracterizar as populações de células presentes nos órgãos linfoides periféricos e nos locais de inflamação, os mesmos foram processados para obtenção dos leucócitos. Além disso, realizou-se uma cultura in vitro com reestímulo para detecção da produção de citocinas intracelulares pelas células dos animais tratados. Para obter as células do baço e LNM, os animais foram devidamente eutanasiados e os respectivos órgãos removidos e processados. Meio de cultura RPMI 1640 (Gibco-Invitrogen, Grand Island, NY, EUA) foi utilizado para a manutenção das células em várias etapas do experimento. Este meio de cultura foi suplementado com aminoácidos não essenciais (MEM non-essential amino acid solution - Sigma-Aldrich, Saint-Louis, $\mathrm{MO}, \mathrm{EUA}), 23,8 \mathrm{mM}$ de $\mathrm{NaHCO}_{3}, 10,9 \mathrm{mM}$ de HEPES, $2 \mathrm{mM}$ de L-glutamina, $1 \mathrm{mM}$ de piruvato de sódio, $500 \mu \mathrm{M}$ de $\beta$-mercaptoetanol, $100 \mathrm{U} / \mathrm{mL}$ de 
penicilina e $100 \mu \mathrm{g} / \mathrm{mL}$ de streptomicina (ambos fornecidos por Gibco-Invitrogen, Grand Island, NY, EUA), pH7,2-7,4. Para fins de simplificação, o meio de cultura RPMI 1640 suplementado será mencionado apenas como "meio RPMl" ao longo do texto e as modificações, quando presentes, serão especificadas.

Assim, a suspensão de células do baço foi lavada em meio RPMI contendo 5\% de soro fetal bovino (SFB; Gibco-Invitrogen, Grand Island, NY, EUA) e tratada por 4 minutos com tampão de lise $\left(\mathrm{NH}_{4} \mathrm{Cl}\right.$ 155mM, $\mathrm{KHCO}_{3} 10 \mathrm{mM}$ e EDTA 0,1mM, pH 7,2). Em seguida, as células do baço e LNM foram lavadas duas vezes em meio RPMI contendo 5\% de SFB e preparadas para contagem de células vivas em hemocitômetro e azul de tripan $0,4 \%$.

Para obtenção de células da lamina própria (LP) e de linfócitos intraepiteliais (LIE), o intestino grosso foi coletado, lavado com tampão HBSS para remoção do conteúdo do lúmen intestinal, aberto longitudinalmente e fragmentado em pedaços de aproximadamente $1 \mathrm{~cm}$. Esses pedaços foram adicionados em meio LIE (RPMI sem a suplementação descrita anteriormente, com adição apenas de tampão HEPES 20mM, 100U/mL de penicilina, $100 \mu \mathrm{g} / \mathrm{mL}$ de strepnomicina e $20 \%$ de SFB) e incubados a $37^{\circ} \mathrm{C}$ por 30 minutos sob agitação vigorosa. Após o período de incubação, os tubos contendo os tecidos foram novamente agitados de forma vigorosa para liberação dos LIE para o meio e, posteriormente, foram acondicionados por 5 minutos em gelo para reduzir a espuma formada. Logo em seguida, a solução foi filtrada em peneira de $70 \mu \mathrm{m}$, sendo que o filtrado resultante continha os LIE e os fragmentos retidos pela peneira continham a LP. Para extrair as células da LP, os fragmentos retidos foram incubados com $50 \mu \mathrm{g} / \mathrm{mL}$ de liberase TL (Roche, Mannheim, Alemanha) em meio RPMI (suplementado apenas com 23,8mM de $\mathrm{NaHCO}_{3}$ e 10,9mM de HEPES; livre de SFB) a $37^{\circ} \mathrm{C}$, por 60 minutos e sob agitação. Após o período de incubação, o tecido digerido foi macerado e filtrado em peneira de $70 \mu \mathrm{m}$ para a obtenção das células. Os tubos contendo os LIE ou as células da LP foram então centrifugados a $300 \mathrm{xg}$ por 20 minutos e $4^{\circ} \mathrm{C}$ e, posteriormente, as células mononucleares foram obtidas por separação por gradiente em Ficoll-Paque ${ }^{T M}$ PLUS (GE Healthcare, Uppsala, Suécia). Finalmente, as células vivas obtidas foram quantificadas em hemocitômetro e azul de tripan 0,4\%. 


\subsection{Citometria de fluxo}

Para imunofenotipagem celular por citometria de fluxo, as células extraídas foram utilizadas diretamente para marcação ou previamente colocadas em cultura ex vivo. $\mathrm{Na}$ marcação direta, os leucócitos do baço, LNM, LIE e LP foram ressuspensos em 1\% de leite em pó desnatado diluído em PBS $1 \times$ na concentração de $1 \times 10^{7}$ células $/ \mathrm{mL}$ e incubados por 30 minutos a $4^{\circ} \mathrm{C}$ para bloqueio de ligações inespecíficas. Após este período, foram adicionados anticorpos específicos acoplados à fluorocromos para moléculas de superfície (CD3, CD4, CD8, CD49b, CD25, CD11b, CD11c, GITR, PD1 e/ou TCR үठ̄) e as células foram incubadas por 30 minutos a $4^{\circ} \mathrm{C}$. Em seguida, as células foram lavadas com $500 \mu \mathrm{L}$ de PBS 1x, centrifugadas por 5 minutos a $400 \times g$ e, aquelas não direcionadas à marcação de moléculas intracelulares foram fixadas em PBS contendo formol 1\% e levadas para leitura em citômetro de fluxo (FACSCanto II - BD Bioscience, San Diego, CA, EUA). As células direcionadas à marcação de moléculas intracelulares (FoxP3 e CTLA-4) foram submetidas à fixação e permeabilização com o uso dos tampões para FoxP3 (Mouse FoxP3 Buffer Set, BD Bioscience, San Diego, CA, EUA), seguindo as recomendações do fabricante e, finalmente, fixadas com formol $1 \%$ em PBS.

Para realização das culturas ex vivo, leucócitos do baço e dos LNM foram estimulados por 4 horas com 50ng/mL de forbol-12-miristato-13-acetato (PMA - phorbol-12-myristate-13acetate - Sigma-Aldrich, Saint-Louis, MO, EUA) e 500ng/mL de ionomicina (Sigma-Aldrich, Saint-Louis, MO, EUA), na presença de brefeldina (Golgi stop, BD Bioscience, San Diego, CA, EUA), a $37^{\circ} \mathrm{C}$ em estufa com $5 \%$ de $\mathrm{CO}_{2}$. Posteriormente, as células foram coletadas, lavadas com PBS 1x, bloqueadas e marcadas para moléculas de superfície (CD3 e/ou CD4), como já descrito anteriormente. Após, as células foram então lavadas e permeabilizadas com tampão de permeabilização (PBS 1x contendo SFB 1\% e saponina 1\%) e, em seguida, incubadas com anticorpos específicos para citocinas acoplados a fluorocromos (IFN-y, IL-17, IL-10 e/ou IL-4) por 30 minutos a $4^{\circ} \mathrm{C}$. Passado este tempo, as células foram lavadas e fixadas com formol 1\% em PBS $1 x$. 
Os anticorpos utilizados para marcação estavam conjugados aos fluorocromos PE, FITC, Alexa Fluor 488, PerCP, APC ou PE-Cy7 (BD Bioscience, San Diego, CA, EUA); a aquisição das células marcadas foi realizada em citômetro de fluxo (FACSCanto II - BD Bioscience, San Diego, CA, EUA) e as análises realizadas pelo software FlowJo (Tree Star, Ashland, OR, EUA).

\subsection{Separação de células T FoxP3+CD4 ${ }^{+}$}

Camundongos C57BL/6 FoxP3-GFP+ knock in, fêmeas, foram devidamente eutanasiados e tiveram o baço e linfonodos (submandibulares, poplíteos, axilares e inguinais) assepticamente removidos e mantidos em meio RPMI com SFB 10\%. Após, os órgãos foram cuidadosamente macerados e filtrados em peneira de $70 \mu \mathrm{m}$ para a obtenção de células. Em seguida, as células foram centrifugadas a $300 \times g$ por 10 minutos e $4^{\circ} \mathrm{C}$ e, posteriormente, submetidas à separação por gradiente em Ficoll-Paque ${ }^{T M}$ PLUS para obtenção de leucócitos mononucleares. As células vivas obtidas foram quantificadas em hemocitômetro e azul de tripan $0,4 \%$ e, então, ressuspensas em meio RPMI contendo SFB 10\% na concentração de $2 \times 10^{7}$ células $/ \mathrm{mL}$. Subsequentemente, as células foram marcadas com anticorpos anti-CD4 acoplados ao fluorocromo PERCP (BD Bioscience, San Diego, CA, EUA) por 30 minutos e $4^{\circ} \mathrm{C}$, lavadas e novamente ressuspensas em mesmo volume de RPMI com SFB $10 \%$. Finalmente, elas foram levadas para separação de células (cell sorting) $\mathrm{CD}^{+}{ }^{+} \mathrm{FoxP} 3^{+}$, supostamente reguladoras, em aparelho BD FACSAria' ${ }^{T M}$ III (BD Bioscience, San Diego, CA, EUA).

\subsection{Ensaio de proliferação celular com carboxifluoresceína succinimidil éster} (CFSE) in vitro e ex vivo

Para o experimento in vitro, as células do baço de camundongos saudáveis foram assepticamente isoladas como previamente descrito, mantidas em RPMI (suplementado apenas com 23,8mM de $\mathrm{NaHCO}_{3}$ e $10,9 \mathrm{mM}$ de HEPES; livre de SBF) e quantificadas em 
hemocitômetro. Posteriormente, as células obtidas foram marcadas com carboxifluoresceína succinimidil éster (CFSE - Sigma-Aldrich, Saint-Louis, MO, EUA) $5 \mu M$ diluída em meio RPMI (suplementado apenas com 23,8mM de $\mathrm{NaHCO}_{3}$ e 10,9mM de HEPES; livre de SBF) em banho-maria a $37^{\circ} \mathrm{C}$, por 10 minutos e sob agitação suave e contínua. Após o período de incubação, adicionou-se SFB em quantidade suficiente para alcançar a concentração de $5 \%$. Depois de 2 lavagens em meio RPMI contendo $5 \%$ de SFB, $5 \times 10^{5}$ células/poço foram distribuídas em triplicata em placas de cultura de 96 poços e estimuladas com concanavalina

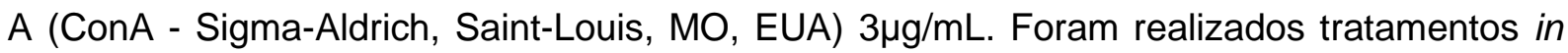
vitro com diferentes concentrações e combinações de DX $(0,1 ; 1$ e $5 \mu \mathrm{M})$ e ATO $(5$ e $10 \mu \mathrm{M})$, como descrito no item "Tratamentos in vivo e in vitro". As células foram deixadas em cultura por 72 horas a $37^{\circ} \mathrm{C}$ em estufa contendo $5 \%$ de $\mathrm{CO}_{2}$. Após o tempo de cultura, a placa foi rapidamente centrifugada, o sobrenadante coletado e armazenado a $-70^{\circ} \mathrm{C}$ para a determinação de citocinas; as células também foram colhidas e levadas para leitura em citômetro de fluxo.

Considerando o experimento ex vivo, as células do baço de camundongos tratados com as diferentes combinações de drogas foram obtidas e marcadas com CFSE, seguindo o mesmo protocolo descrito anteriormente. Após, $5 \times 10^{5}$ células/poço foram distribuídas em triplicata em placas de cultura de 96 poços e estimuladas com $3 \mu \mathrm{g} / \mathrm{mL}$ de ConA. Após 72 horas de incubação a $37^{\circ} \mathrm{C}$ em estufa de $\mathrm{CO}_{2}$, a placa foi centrifugada, o sobrenadante coletado e as células também direcionadas para leitura em citômetro de fluxo.

\subsection{Ensaio de detecção de morte celular}

Para a avaliação da viabilidade celular no ensaio com tratamentos in vitro, foi realizado o mesmo protocolo de extração de células do baço, contagem, estimulação, tratamentos e períodos de incubação descritos no item anterior (exceto o passo de marcação com CFSE). Passado o tempo de 72 horas de cultura, o sobrenadante foi coletado e armazenado a $-70^{\circ} \mathrm{C}$ para a determinação de citocinas e, após o recolhimento das células, as mesmas foram 
marcadas com Anexina-V e iodeto de propídio (Annexin-V-FLUOS Staining kit - Roche, Mannhelm, Alemanha) para a verificação de morte celular por apoptose e/ou necrose, seguindo as instruções do fabricante. As células foram analisadas por leitura em citômetro de fluxo. Saponina $0,01 \%$ foi utilizada como controle positivo para a indução de morte celular por necrose, que foi caracterizada pela marcação concomitante de anexina e $\mathrm{PI}\left(\right.$ Anexina $\left.^{+} \mathrm{PI}^{+}\right)$, enquanto que a apoptose foi detectada pela simples marcação de anexina (Anexina ${ }^{+} \mathrm{PI}^{-}$). Células vivas foram diferenciadas das mortas quando não possuíram marcação tanto para anexina, como para $\mathrm{PI}\left(\right.$ Anexina $\left.^{-} \mathrm{PI}^{-}\right)$; células Anexina- $\mathrm{PI}^{+}$não possuem significado biológico.

\subsection{Cultura ex vivo de esplenócitos na presença de células $\mathrm{T} \mathrm{CD} 4^{+} \mathrm{FoxP}^{+} \mathrm{e}$} ensaio de proliferação celular pela incorporação de bromodeoxiuridina

Para avaliar a responsividade das células de animais tratados com DX e ATO simples ou em combinação, frente a sinais reguladores, esplenócitos foram co-cultivados na presença de células supostamente reguladoras $\left(\mathrm{CD}^{+}{ }^{+} \mathrm{FoxP} 3^{+}\right)$para avaliação da influência desta população na proliferação daquelas. Resumidamente, as células do baço de camundongos C57BL/6, fêmeas, tratadas ou não, foram coletadas e co-cultivadas na presença de células $\mathrm{T} \mathrm{CD4}^{+} \mathrm{FoxP}^{+}$de animais saudáveis, previamente separadas por citometria de fluxo, como descrito anteriormente. As proporções de Tregs e células de baço utilizadas foram de 1:10 e 1:5, respectivamente. Estas células foram estimuladas com Con-A $3 \mu \mathrm{g} / \mathrm{mL}$ e incubadas a $37^{\circ} \mathrm{C} / 5 \% \mathrm{CO}_{2}$ por 72 horas. Também foi observada a proliferação de células dos respectivos grupos na presença e na ausência de estimulação, sem a inclusão de células CD4+FoxP3 ${ }^{+}$. Nas últimas 15 horas de cultura, adicionou-se $10 \mu \mathrm{M}$ de bromodeoxiuridina (BrdU), um nucleosídeo sintético análogo à timidina que é incorporado às novas fitas de DNA sintetizado de células em processo de replicação, substituindo a timidina. Desse modo, o aumento da incorporação de BrdU indica aumento da síntese de DNA e maior atividade proliferativa das células. Após este período, as células foram fixadas na superfície da placa e cuidadosamente lavadas para posterior incubação de 30 minutos com o anticorpo anti-BrdU acoplado à enzima peroxidase. Os poços foram novamente lavados com PBS 1x, 
incubados por 30 minutos com TMB (BD Bioscience, San Diego, CA, EUA) e a reação foi interrompida com a adição de $\mathrm{H}_{2} \mathrm{SO}_{4} 1 \mathrm{M}$. Por fim, realizou-se a leitura em espectrofotômetro a $450 \mathrm{~nm}$ e os resultados foram expressos em densidade óptica (DO). Os valores de DO provenientes dos poços contendo células estimuladas com ConA na ausência de células Treg foram divididos pela média das DO de células não estimuladas, com o objetivo de se obter um "índice de estimulação". Ainda, os valores de DO obtidos por células estimuladas com ConA na presença de células Treg foram também divididos pela média das DO de células não estimuladas, com o objetivo de se obter um "índice de estimulação na presença de Treg" ou “índice de Treg”. Em seguida, o "índice de Treg” foi dividido pela média dos valores do "índice de estimulação" e o resultado desta análise foi chamado de "proliferação resistente à presença de Treg", que demonstra o quanto esplenócitos provenientes das diferentes condições experimentais foram capazes de se proliferar na presença de supressão mediada por células Treg.

\subsection{Dosagem de citocinas e Fas-L por imunoensaio enzimático (ELISA)}

A presença e a concentração de citocinas inflamatórias foram avaliadas por imunoensaio enzimático (ELISA - Enzyme Linked Immuno Sorbent Assay) sandwich no sobrenadante das culturas de esplenócitos dos experimentos in vitro (IL-6 e IL-10) e ex vivo (IL-10) de acordo com as instruções fornecidas pelo fabricante (OpTEIA, BD Bioscience, San Diego, CA, EUA). Ainda, a quantificação da proteína Fas ligante (Fas-L ou CD178 ou TNFSR6) foi determinada no homogenato de cólon dos animais expostos ao DSS e submetidos aos diferentes tratamentos, também de acordo com as instruções do fabricante (ELISA Mouse Fas Ligand/ TNFSR6 Immunoassay, Quantikine ${ }^{\circledR}$, R\&D Systems, Minneapolis, MN, EUA). A concentração nas amostras foi determinada empregando-se curva de diluição seriada do padrão de cada proteína. Todos os resultados foram expressos em $\mathrm{pg} / \mathrm{mL}$, sendo que para o Fas-L, as concentrações foram corrigidas pelo peso do tecido em gramas. 


\subsection{Análise estatística}

Os gráficos e as análises estatísticas foram realizados com auxílio do software Graphpad Prism® 5 (versão 5.0). Em todas as variáveis foram testadas a distribuição normal e a variância homogênea. Quando a distribuição foi considerada normal e com variância homogênea foi utilizado teste paramétrico ANOVA com pós-teste de Tukey para três ou mais grupos ou teste T de Student para 2 grupos. Os resultados foram expressos em média \pm SEM (erro padrão da média). Nos casos em que a distribuição não foi Gaussiana utilizou-se teste não paramétrico ANOVA Kruskal Wallis com pós-teste de Dunns no caso de três ou mais grupos ou teste Mann-Whitney para 2 grupos. Para análises de mortalidade foram utilizados teste de LogRank e Gehan-Breslow-Wilcoxon. As diferenças observadas foram consideradas significativas quando $p<0,05(5 \%)$. 
4. resultadaos 


\section{RESULTADOS}

\subsection{Determinação das doses e via de administração de atorvastatina para o tratamento da colite experimental}

Devido às fortes evidências encontradas na literatura acerca dos possíveis efeitos imunomoduladores das estatinas em doenças inflamatórias, inclusive na DII, foram realizados experimentos com o objetivo de avaliar o efeito do uso dessas drogas em camundongos C57BL/6 expostos continuamente ao DSS 3\%, bem como determinar a melhor via de administração e dose da droga.

Os camundongos doentes tratados com ATO, de modo geral, tiveram consumo semelhante de DSS e ração durante os 18 dias de experimento, independentemente da dose ou via de administração da droga (Figuras 3A-D). Animais do grupo DSS, ou seja, camundongos doentes que não receberam nenhum tipo de tratamento apresentaram uma pequena variação no consumo do indutor de colite quando comparados aos grupos tratados com ATO por v.o. ou i.p. No geral, houve maior ingestão de DSS nos primeiros 5 dias, seguido pela diminuição do consumo até aproximadamente o dia 9 (Figuras 3A e C). Ainda, observouse uma tênue diminuição no consumo de ração no grupo de animais que não recebeu tratamento específico comparado aos grupos tratados com ATO por v.o. a partir do dia 6 (Figura 3D). 
Via de administração intraperitoneal (i.p.)

A.

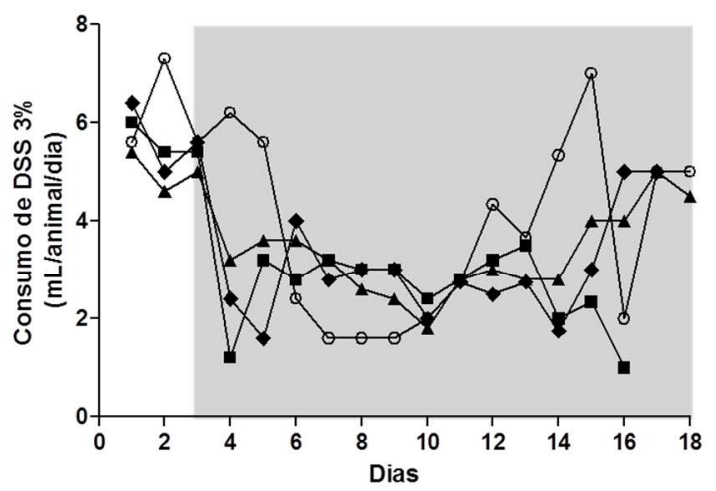

B.

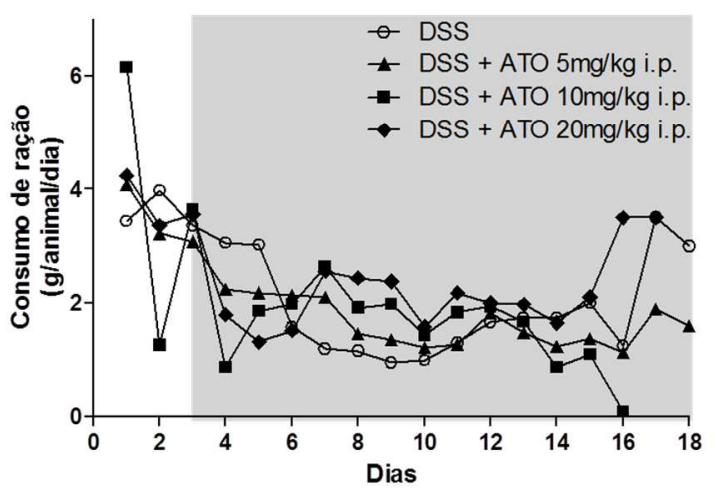

Via de administração oral (v.o.)

C.

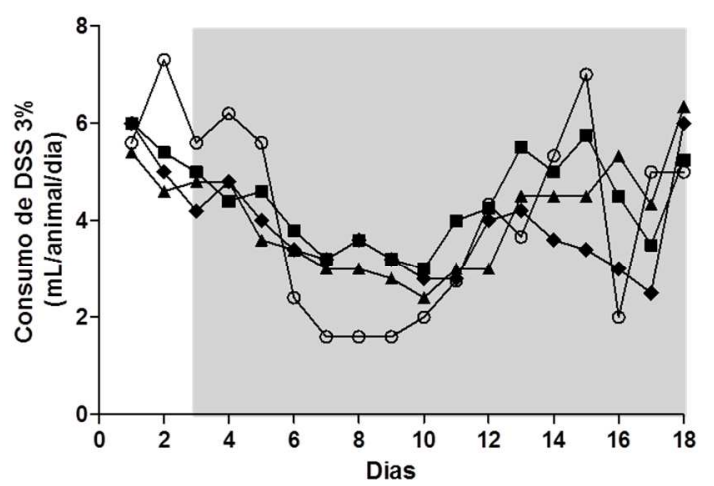

D.

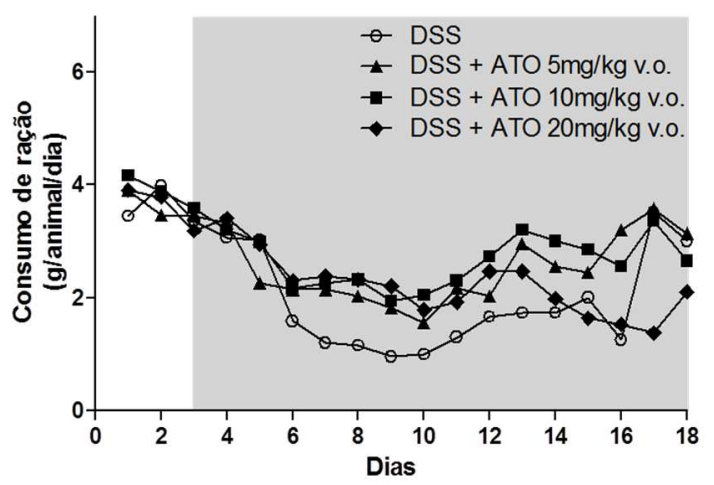

Figura 3. Consumo de água contendo dextran sulfato de sódio (DSS) $3 \%$ (A e C) e consumo de ração (B e D) por camundongos expostos continuamente ao DSS, tratados ou não com atorvastatina (ATO). A-B. Animais receberam diferentes doses diárias de ATO (5, 10 ou 20mg/kg) administradas por via intraperitoneal (i.p.). C-D. Animais receberam diferentes doses diárias de ATO (5, 10 ou $20 \mathrm{mg} / \mathrm{kg}$ ) administradas por via oral (v.o.). A área hachurada corresponde ao início e a duração dos tratamentos (contínuos a partir do $3^{\circ}$ dia de indução da colite). $n=5$ animais por grupo. Estes dados são representativos de um experimento.

Considerando os resultados de variação de peso, observou-se que a administração da droga causou a diminuição da massa corporal dos animais tratados com ATO nos primeiros dias de terapia e essa redução pareceu ser um pouco maior nos animais tratados pela via i.p., principalmente na dose diária de 10mg/kg (Figuras 4A e D). Entretanto, a terapia com ATO alterou o curso clínico da doença já a partir do $3^{\circ}$ dia de tratamento ( $6^{\circ}$ dia de colite). Neste período, os sinais clínicos dos grupos tratados, independentemente da via de administração e dose, foram mais brandos quando comparados ao grupo que recebeu apenas DSS (Figuras 4B e E), mantendo-se relativamente moderados por todo o período do estudo. Vale ressaltar que o tênue aumento no consumo de DSS pelos camundongos do grupo doente sem tratamento não resultou em aumento inicial da perda de peso e do escore clínico, inferindo 
que não houve influência significativa dessa ingestão nos parâmetros analisados. Ainda, animais tratados com ATO i.p. não apresentaram diferença na taxa de sobrevida quando comparados ao grupo que recebeu apenas DSS, enquanto que nos animais tratados com a droga por v.o. essa taxa foi expressivamente maior (Figuras 4C e F).

Ao comparar as diferentes doses dos tratamentos de ATO por v.o., a dose diária de $10 \mathrm{mg} / \mathrm{kg}$ evitou maior perda de peso, diminuiu e preservou em níveis reduzidos os sinais clínicos da doença durante todo o período de experimento, aumentando os índices de sobrevivência quando comparada às outras concentrações do fármaco. Desse modo, a dose diária de ATO escolhida para os estudos de associação de drogas foi de $10 \mathrm{mg} / \mathrm{kg}$, a ser administrada por v.o. 
Via de administração intraperitoneal (i.p.)

A.

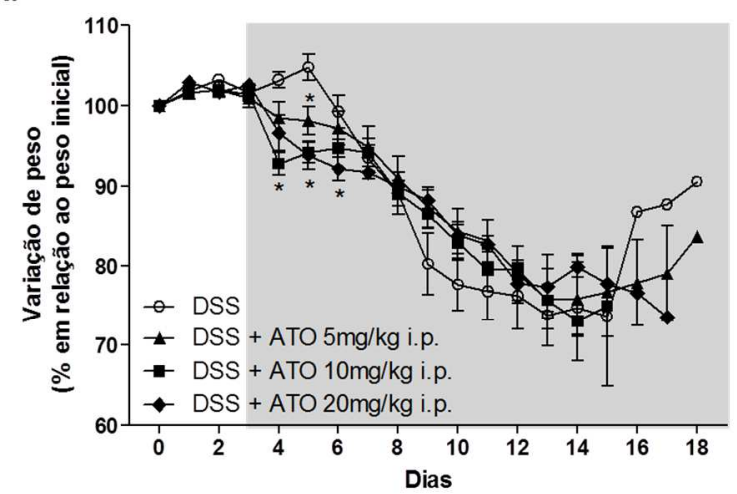

B.

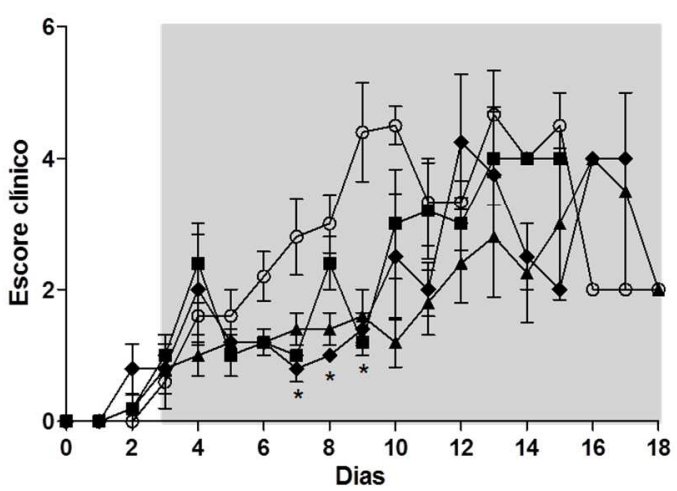

C.

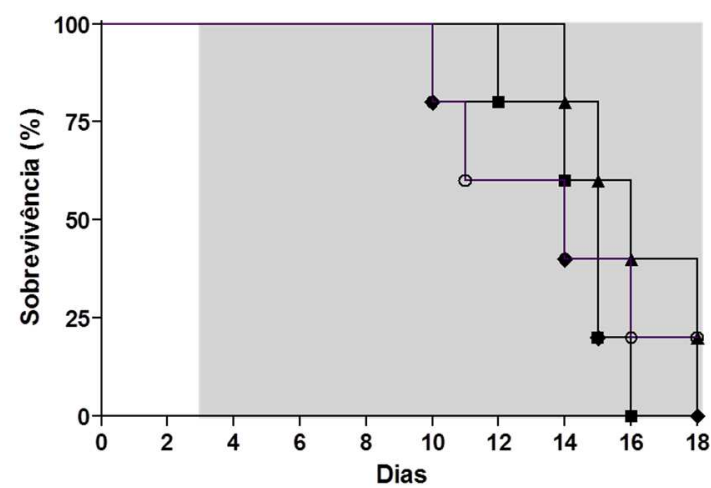

Via de administração oral (v.o.)

D.

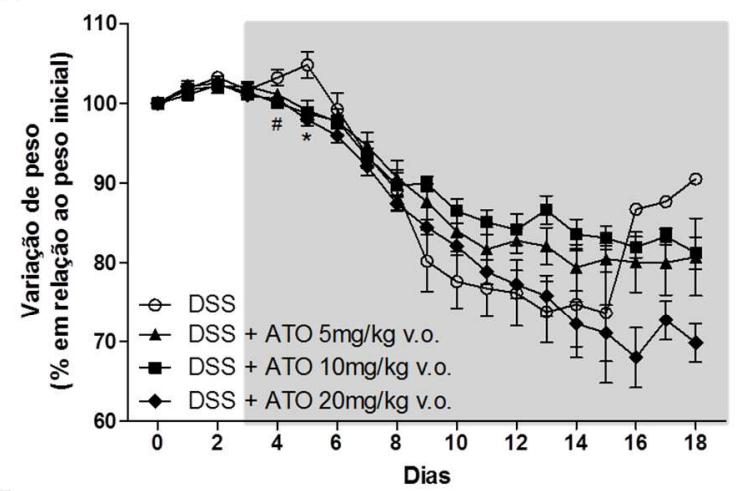

E.

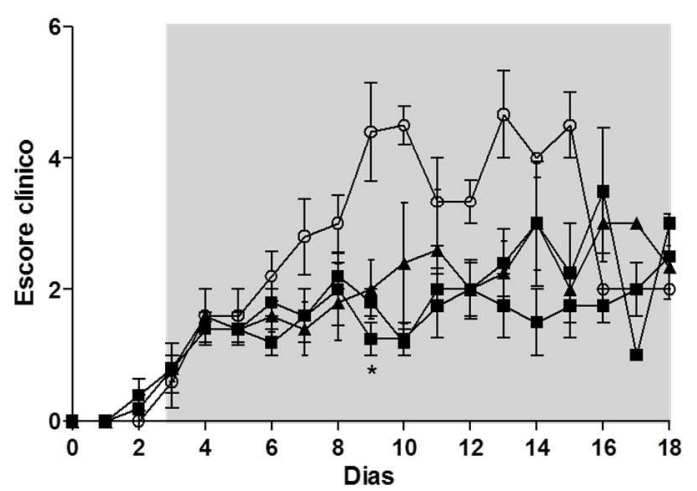

F.

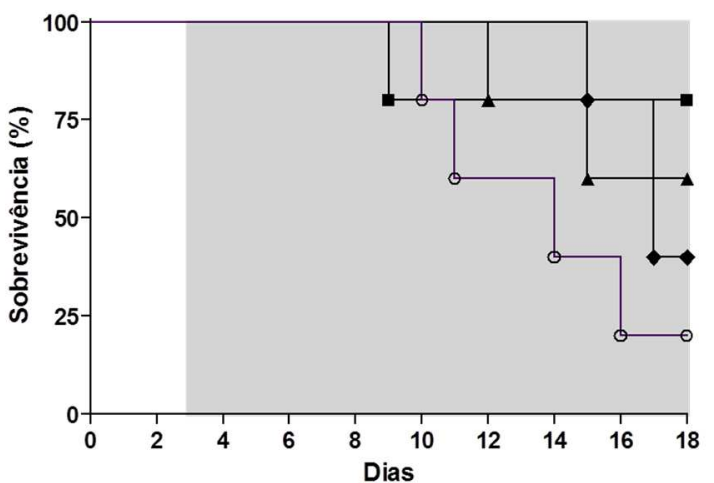

Figura 4. Variação de peso, escore clínico e taxa de sobrevivência de camundongos expostos continuamente à água contendo dextran sulfato de sódio (DSS) $3 \%$, tratados ou não com atorvastatina (ATO). Animais receberam diferentes doses diárias de ATO (5, 10 ou $20 \mathrm{mg} / \mathrm{kg}$ ) administradas por via intraperitoneal (i.p.) (A-C) ou oral (v.o.) (D-F). A área hachurada corresponde ao início e a duração dos tratamentos (contínuos a partir do $3^{\circ}$ dia de indução da colite). $n=5$ animais por grupo. Estes dados são representativos de um experimento. * $p<0,05$ : comparado ao grupo DSS; ${ }^{\#} p<0,05$ : grupo DSS + ATO 10mg/kg comparado ao grupo DSS. 


\subsection{Determinação da via de administração e validação da dose de dexametasona para o tratamento da colite experimental}

DX é um glicocorticoide utilizado em diversos trabalhos da literatura envolvendo DII experimental, inclusive em estudos que usam a droga como referência para comparar a eficácia de novos tipos de tratamentos, empregando-se a dose diária de 1mg/kg (BAGHAEI et al., 2010; BENTO et al., 2008; FAKHRAEl et al., 2014; REUTER et al., 2012; WU et al., 2012). Com base nesses estudos e em outros trabalhos do nosso grupo de pesquisa (resultados ainda não publicados), buscou-se apenas verificar se os efeitos da dose diária de $1 \mathrm{mg} / \mathrm{kg}$ da droga eram alterados pelas diferentes vias de administração (i.p. e v.o.), uma vez que estudos de associação de drogas priorizam a v.o. para tratamentos farmacológicos.

De maneira geral, camundongos tratados ou não com DX não apresentaram diferenças significativas no consumo de DSS e ração pelo período do experimento (Figuras 5A-B). As análises dos parâmetros clínicos mostraram não haver diferença entre as vias de administração i.p. e v.o. Entretanto, o uso contínuo de DX prejudicou parcialmente o curso da doença, causando aumento da perda de peso após o $6^{\circ}$ dia de exposição ao DSS e antecipação da mortalidade dos animais doentes, independentemente da via de administração da droga (Figuras 5C-E).

Uma vez que não houve diferença significativa entre as vias de administração utilizadas, optou-se pela escolha da dose diária de $1 \mathrm{mg} / \mathrm{kg}$ de DX por v.o. já que, como discutido anteriormente, os estudos de associação de drogas utilizam esta via de administração preferencialmente.

Por conseguinte, as doses diárias escolhidas para o presente estudo foram ATO $10 \mathrm{mg} / \mathrm{kg}$ e DX $1 \mathrm{mg} / \mathrm{kg}$, ambas administradas por v.o. e em doses somadas, que foram utilizadas para verificar o efeito da terapia associada na colite experimental induzida por DSS. 
A.

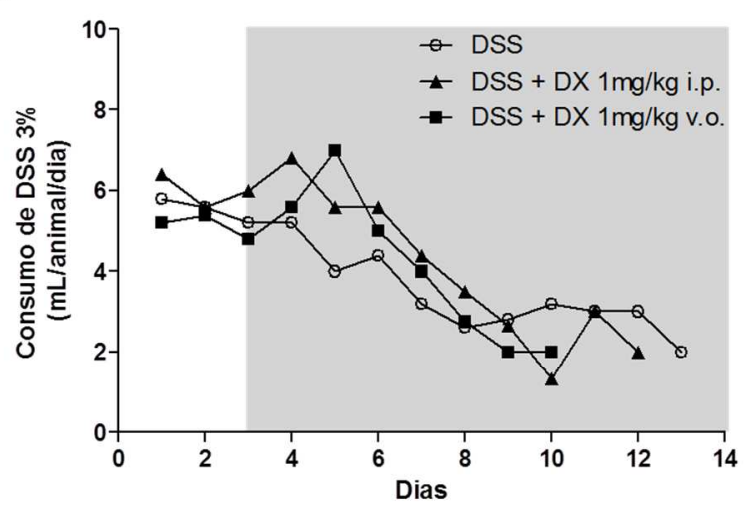

C.

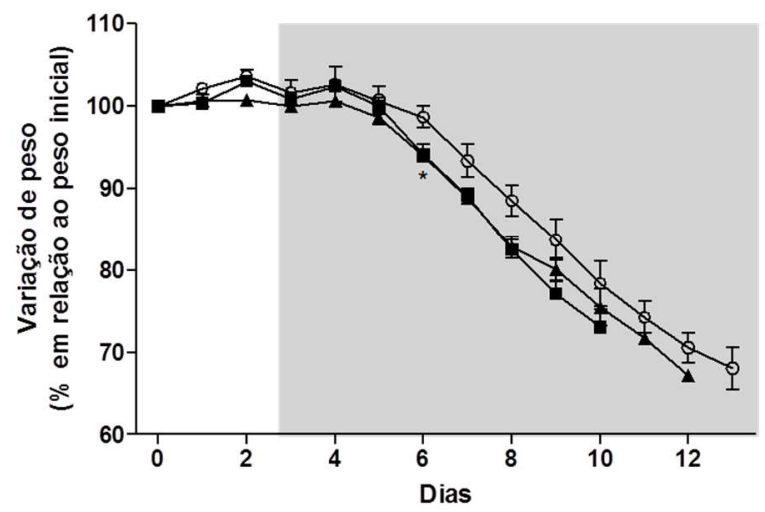

E.

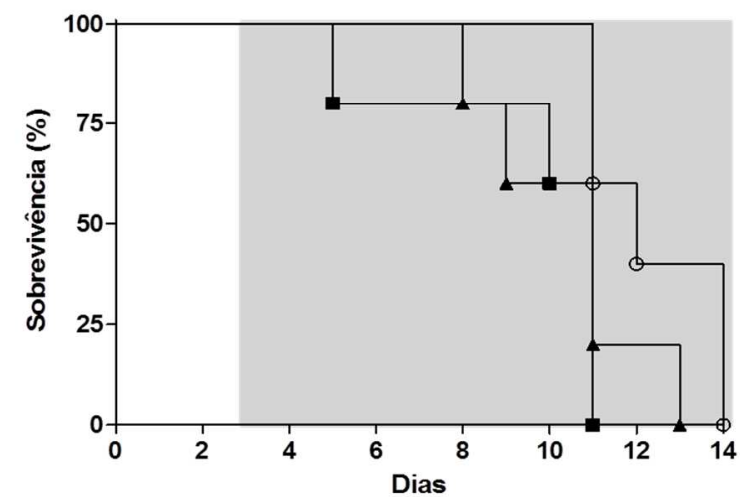

B.

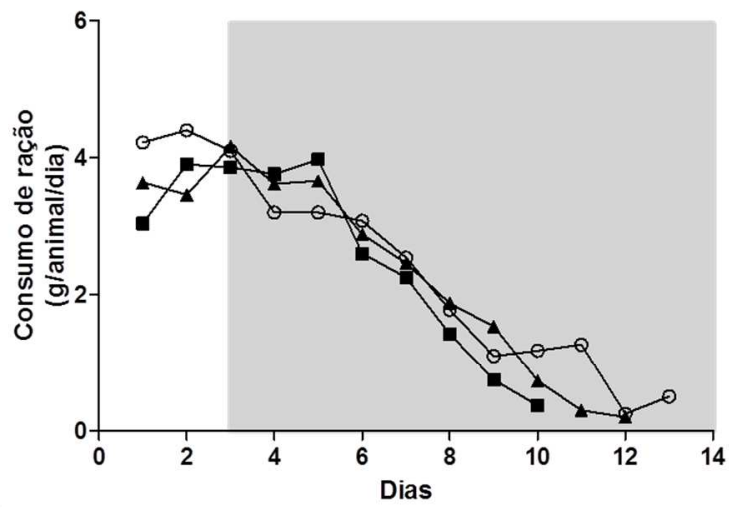

D.

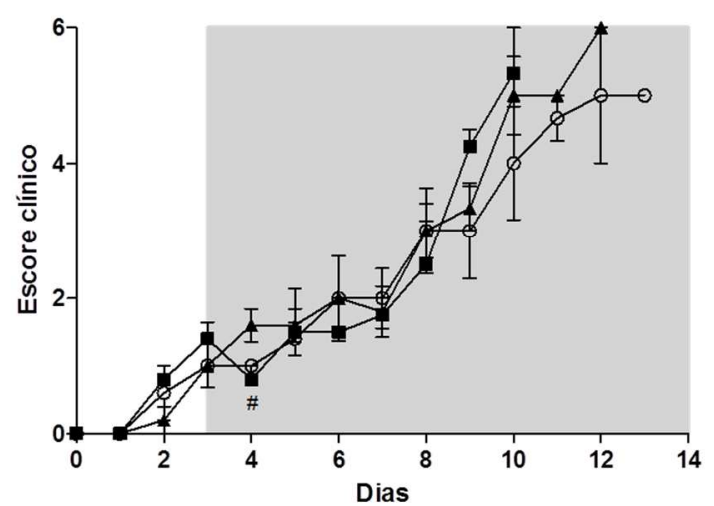

Figura 5. Consumo de água contendo dextran sulfato de sódio (DSS) $3 \%$ (A), ração (B), variação de peso (C), escore clínico (D) e taxa de sobrevivência (E) de camundongos expostos continuamente ao DSS, tratados ou não com dexametasona (DX). Os animais receberam a dose diária de $1 \mathrm{mg} / \mathrm{kg}$, administrada por via intraperitoneal (i.p.) ou oral (v.o.). A área hachurada corresponde ao início e à duração dos tratamentos (contínuos e diários a partir do $3^{\circ}$ dia de indução da colite). Estes dados são representativos de um experimento. $n=5$ animais por grupo. ${ }^{*} p<0,05$ : grupo DSS + DX $1 \mathrm{mg} / \mathrm{kg}$ i.p. comparado ao grupo DSS; $\#<<0,05$ : grupo DSS + DX $1 \mathrm{mg} / \mathrm{kg}$ i.p. comparado ao grupo DSS + DX $1 \mathrm{mg} / \mathrm{kg}$ v.o. 


\subsection{Avaliação do tratamento contínuo com dexametasona e atorvastatina na colite experimental}

Definidas as doses de ATO e DX, procurou-se observar o efeito do tratamento contínuo das drogas associadas, avaliando-se os mesmos parâmetros investigados até o momento. Para isso, camundongos expostos continuamente ao DSS foram tratados diariamente e em dose única com o veículo das drogas (salina), DX $1 \mathrm{mg} / \mathrm{kg}$, ATO 10mg/kg ou DX $1 \mathrm{mg} / \mathrm{kg} \mathrm{em}$ conjunção com ATO 10mg/kg, sempre por v.o., a partir do aparecimento dos sinais clínicos da doença ( $3^{\circ}$ dia após início de exposição ao DSS).

A análise do experimento mostrou não haver diferenças significativas no consumo de água contendo DSS 3\% e de ração entre os grupos estudados nos primeiros 3 dias (Figuras $6 A-B)$, o que refletiu em alta homogeneidade no desenvolvimento da doença. Após o início dos tratamentos ( $3^{\circ}$ dia de experimento), os animais dos grupos tratados com DX isolada ou em combinação com ATO diminuíram, de maneira geral, o consumo de ração a partir do $8^{\circ}$ e $7^{\circ}$ dia, respectivamente, quando comparados ao grupo doente tratado com salina.

Camundongos tratados isoladamente com DX ou em associação com ATO perderam peso significativamente após o início da terapia, sendo esta perda contínua até o fim do experimento (Figura 6C). Não houve diferença na variação de peso entre os grupos de animais tratados com ATO isolada e o veículo.

A avaliação do escore clínico mostrou certa homogeneidade entre os grupos até o $10^{\circ}$ dia do experimento (Figura 6D). Após este período, o curso da doença foi significativamente mais brando nos camundongos tratados com ATO, mas não foi alterado nos animais que receberam as terapias contendo DX quando comparados ao grupo DSS. Entretanto, a análise pormenorizada dos escores clínicos mostrou que após 2 ou 3 doses dos esquemas terapêuticos pareceu existir uma pequena melhora dos animais doentes tratados com DX isolada ou em associação, embora não estatisticamente significativa (Figura 6E).

Apesar da DII aparentemente ter sido mais branda nos camundongos tratados com as diferentes drogas por todo o período do experimento (Figura 6G), as terapias envolvendo DX isolada ou combinada com ATO pareceram antecipar a morte dos animais com DII (Figura 
6F). Já o uso de ATO aumentou a sobrevivência dos camundongos doentes quando comparado aos demais grupos em estudo.

Coletivamente, essas análises mostraram que o uso isolado de ATO modificou positivamente o curso da DII tanto em curto, como em longo prazo. No entanto, as terapias contendo DX agravaram e anteciparam a morte dos animais doentes com o esquema terapêutico de uso contínuo das drogas. Assim, optou-se por avaliar os camundongos expostos ao DSS após períodos curtos das terapias, de modo a compreender quais as alterações imunológicas iniciais, induzidas pelos tratamentos, seriam responsáveis pelos diferentes cursos da doença. 
A.

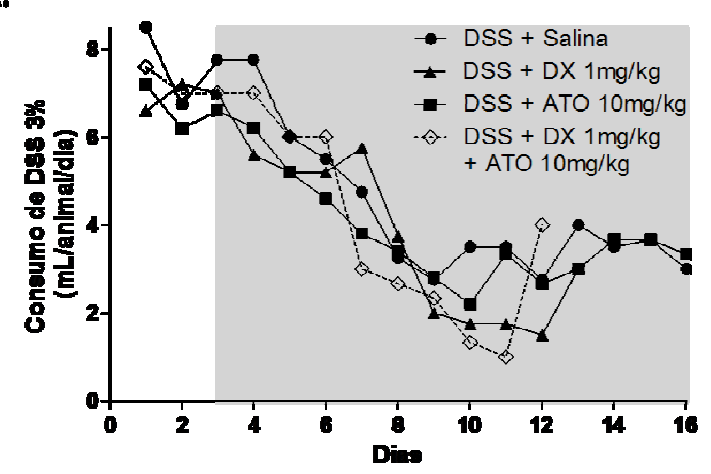

c.

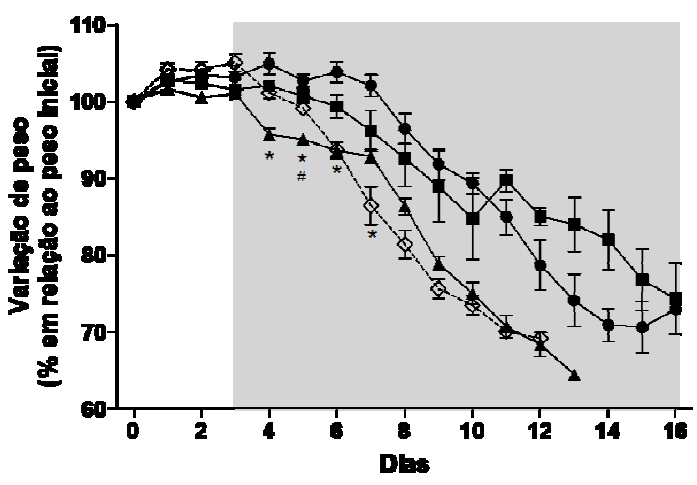

E.

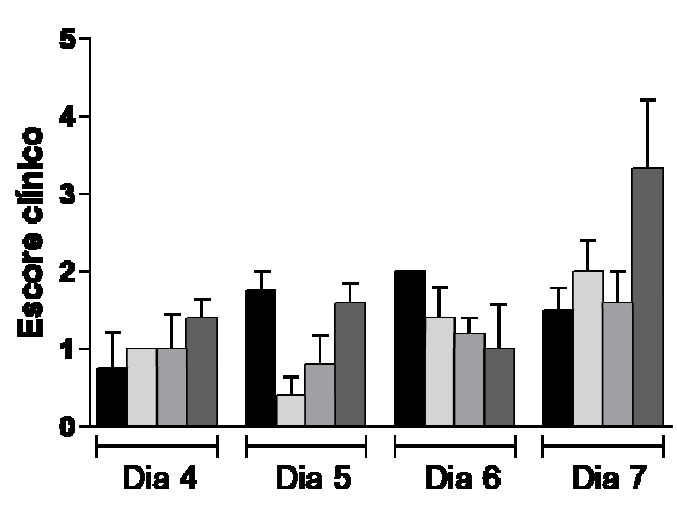

F.

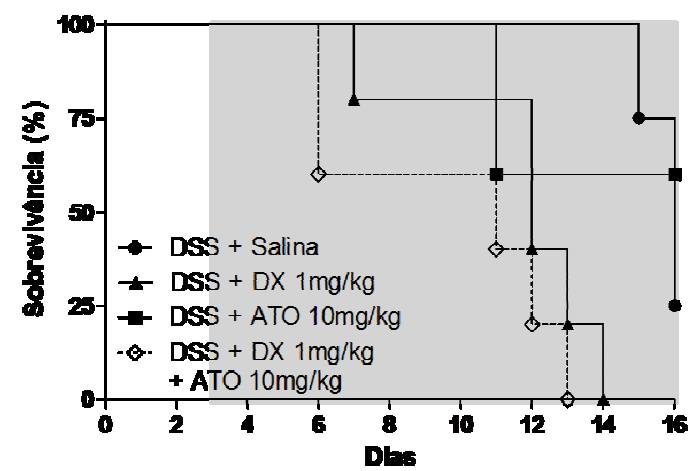

B.

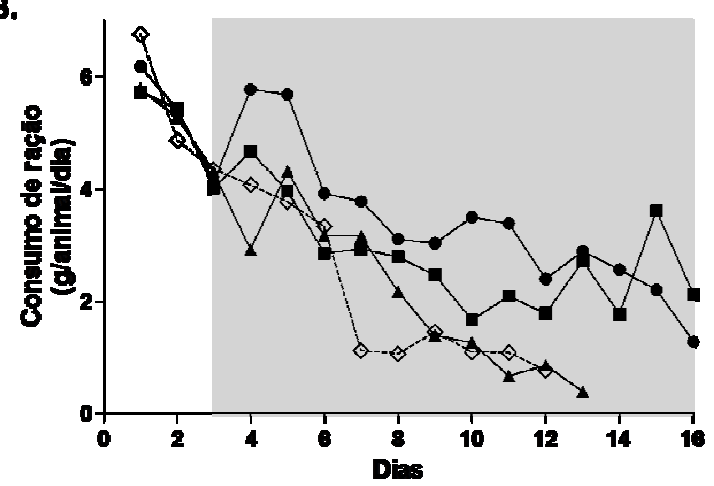

D.

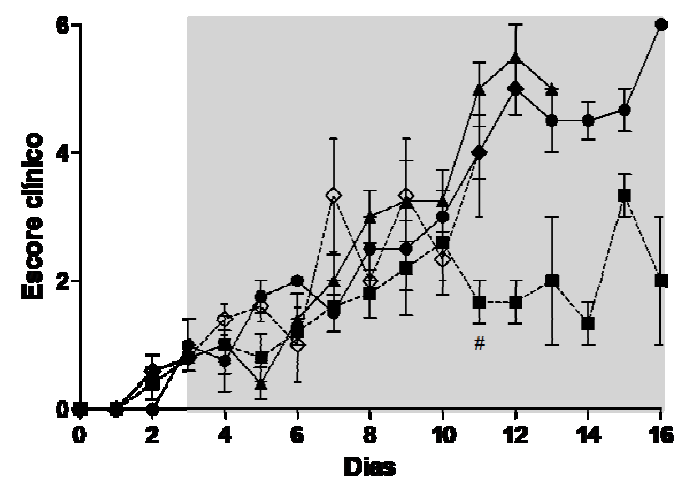

$$
\begin{aligned}
& \text { DSS + Saling } \\
& \text { DSS + DX 1mg/kg } \\
& \text { DSS + ATO } 10 \mathrm{mg} / \mathrm{kg} \\
& \text { DSS + DX } 1 \mathrm{mg} / \mathrm{kg} \\
& + \text { ATO } 10 \mathrm{mg} / \mathrm{kg}
\end{aligned}
$$

G.

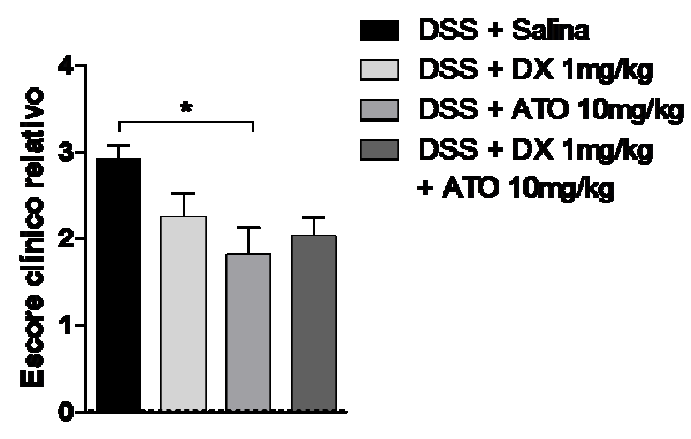

Figura 6. Consumo de água contendo dextran sulfato de sódio (DSS) $3 \%$ (A), ração (B), variação de peso (C), escore clínico (D), escore clínico nos dias 4, 5, 6 e 7 (E), taxa de sobrevivência (F) e escore clínico relativo (G) de camundongos expostos continuamente ao DSS, tratados com o veículo (salina), dexametasona (DX) ou atorvastatina (ATO), isoladamente ou em associação. Animais receberam tratamentos orais contínuos e diários a partir do $3^{\circ}$ dia de indução da colite. As áreas hachuradas dos gráficos A-D e F correspondem ao início e duração dos tratamentos. Estes dados 
são representativos de dois experimentos independentes. $n=5$ animais por grupo. ${ }^{*} p<0,05$ : comparado ao grupo DSS; ${ }^{p}<0,05$ : comparado ao grupo DSS + ATO 10mg/kg.

\subsection{Avaliação do tratamento em curto prazo com dexametasona e atorvastatina}

Para verificar se as diferentes terapias em curtos períodos interferem no curso clínico da colite experimental, os camundongos foram expostos ao DSS por 6 dias e receberam os respectivos tratamentos a partir do $3^{\circ}$ dia de experimento e por 3 dias consecutivos. No $6^{\circ}$ dia, os animais foram devidamente eutanasiados para coleta de amostras com o intuito de avaliar as possíveis alterações imunohistopatológicas causadas pelas diferentes terapias.

O consumo de DSS e de ração entre os grupos doentes tratados com as drogas ou com o veículo foi igual nos dias precedentes e subsequentes aos tratamentos (Figuras 7A-B). Considerando o grupo controle saudável, ou seja, aquele que recebeu água ao invés de DSS e com administração oral do veículo das drogas (salina), houve consumo relativamente maior de água comparado aos grupos que receberam DSS, inferindo que a indução da inflamação intestinal leva à hipodipsia nos camundongos doentes. Ainda, o tratamento com salina e/ou ATO não influenciou a perda de peso dos animais que receberam DSS, sendo semelhante à observada no grupo controle saudável (Figura 7C). Entretanto, nos camundongos tratados com DX, isoladamente ou associada à ATO, a perda de peso foi significativa quando comparada aos demais grupos.

De modo interessante, as terapias contendo ATO (isolada ou em combinação com DX) melhoraram significativamente a condição clínica dos animais durante a indução da colite (Figura 7D), enquanto que os camundongos tratados isoladamente com DX apresentaram apenas uma pequena melhora quando comparados ao grupo doente tratado com salina. Para melhor discernimento, os resultados do escore clínico no $6^{\circ}$ dia de experimento foram mostrados separadamente (Figura 7E) e confirmaram que os tratamentos envolvendo ATO (isolada ou em associação com DX) melhoraram significativamente os sinais clínicos da colite experimental após curtos períodos de uso. Contudo, não foram diferentes entre si. 
Para observar a influência dos tratamentos durante todo o período avaliado (até o $6^{\circ}$ dia de indução de colite), os escores clínicos diários dos camundongos foram somados e observou-se que apenas a terapia isolada com ATO resultou de fato na melhora significativa dos sinais clínicos (Figura 7F).

Os resultados das avaliações do escore pós-morte demonstraram que a associação de DX e ATO não alterou os aspectos macroscópicos do intestino induzidos pela doença (Figura 7G). Quando o escore clínico do $6^{\circ}$ dia de experimento foi somado ao escore pósmorte (escore acumulado da doença) observou-se que o tratamento isolado com ATO melhorou substancialmente os sinais e danos causados pelo DSS. Entretanto, a adição de ATO à terapia com DX não conseguiu melhorar o escore dos camundongos doentes. Assim, inesperadamente, o tratamento combinado exibiu escore acumulado significativamente maior quando comparado ao tratamento isolado com ATO (Figura $7 \mathrm{H})$.

Dessa maneira, a terapia isolada com ATO melhorou os aspectos clínicos e macroscópicos do intestino e, por apresentar menores efeitos indesejados (como a perda de peso) e aumentar a expectativa de vida dos animais doentes, pareceu ser uma opção mais segura para o controle da DII do que as terapias contendo DX. Além disso, a adição de ATO ao tratamento com DX não foi capaz de aumentar ou recuperar os efeitos, até então desfavoráveis, do esteroide. 
A.

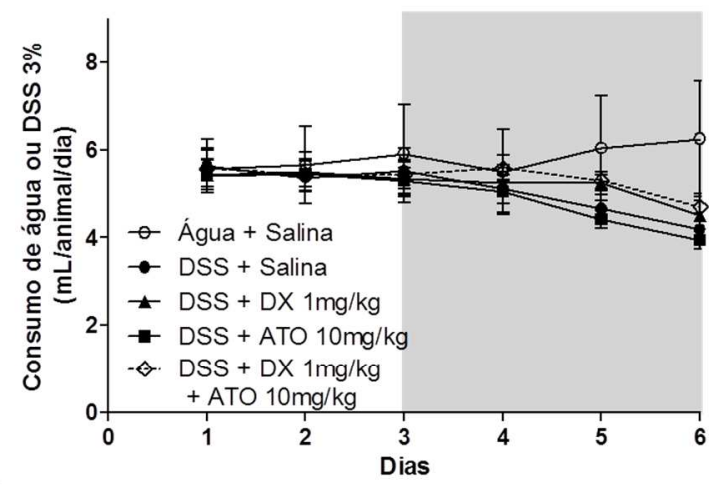

c.

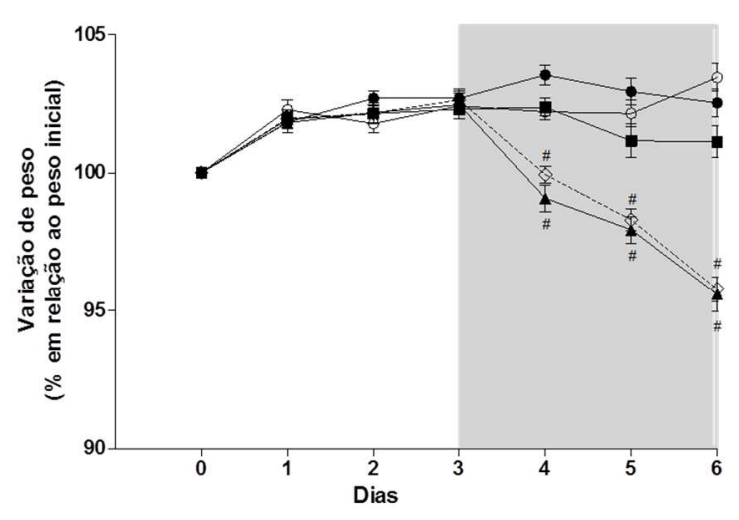

E.

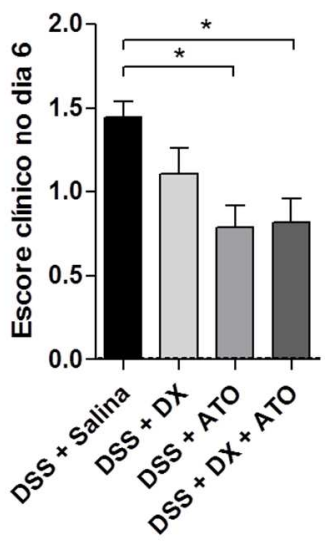

F.

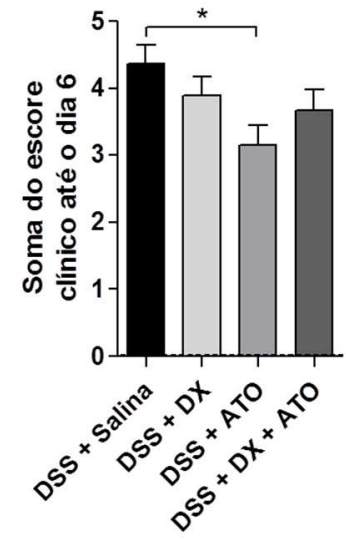

B.

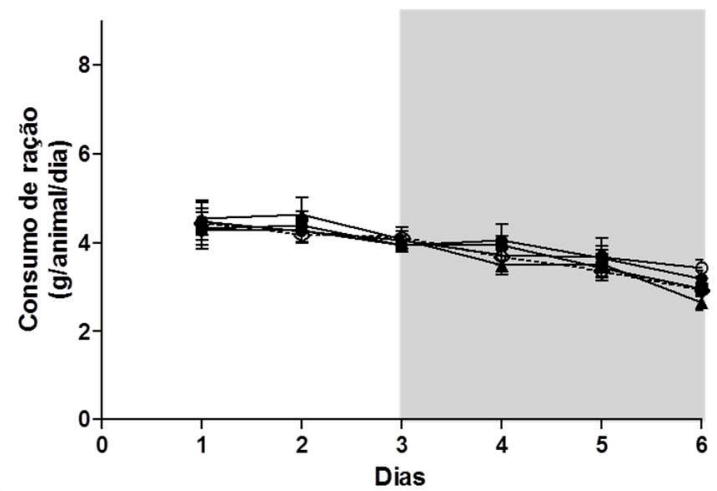

D.

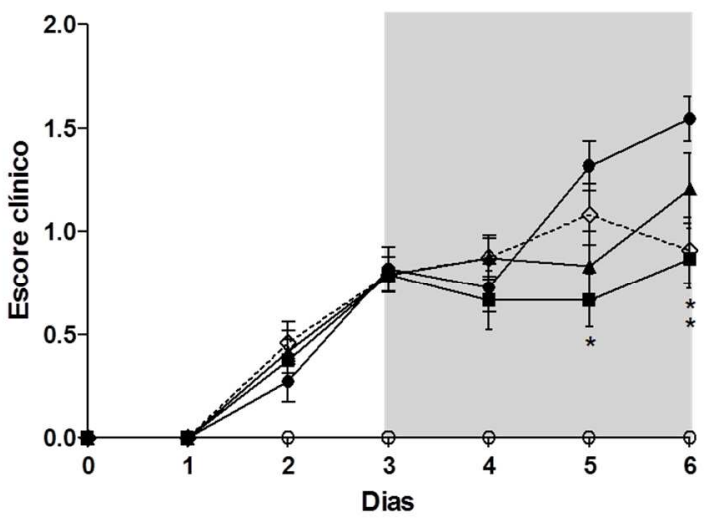

G.

H.
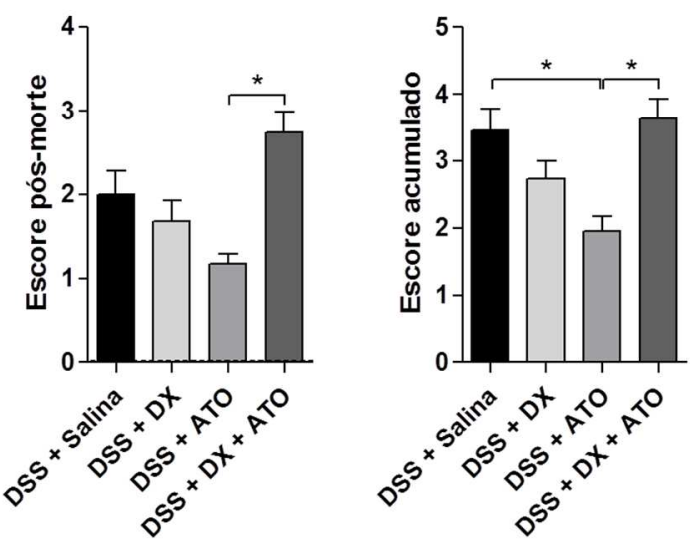

Figura 7. Consumo de água contendo dextran sulfato de sódio (DSS) $3 \%$ ou água (A), consumo de ração (B), variação de peso (C), escore clínico (D), escore clínico no dia 6 (E), soma do escore clínico até o dia $6(F)$, escore pós-morte $(G)$ e escore acumulado $(H)$ de camundongos expostos ao DSS por 6 dias consecutivos, tratados com o veículo (salina), dexametasona (DX) ou atorvastatina (ATO), isoladamente ou em associação. Os animais receberam tratamentos orais por 3 dias a partir do $3^{\circ}$ dia de indução da doença. As áreas hachuradas dos gráficos A-D correspondem ao início e duração dos tratamentos. E. Escore clínico da doença no $6^{\circ}$ dia de experimento. F. Soma do escore clínico dos animais durante os 6 dias de experimento. G. Escore pós-morte da doença obtido pela avaliação macroscópica do conteúdo do cólon dos camundongos. H. Escore acumulado da doença que corresponde à soma do escore clínico do $6^{\circ}$ dia de experimento e do escore pós-morte. Estes dados são representativos de cinco experimentos independentes. $n=5$ animais por grupo. Gráficos de linhas: ${ }^{*}<0,05$ comparado ao grupo DSS + Salina; ${ }^{p} p<0,05$ comparado aos grupos DSS + Salina e DSS + ATO. Gráficos de barras: ${ }^{*} p<0,05$. 


\subsection{Análise do comprimento do cólon após tratamento com dexametasona e atorvastatina}

Está bem estabelecido na literatura que a colite experimental induzida por DSS pode causar o encurtamento do cólon (KIM et al., 2012). Sendo assim, procurou-se avaliar se os respectivos tratamentos farmacológicos poderiam impedir e/ou melhorar essa alteração clínica. A análise mostrou que camundongos que receberam DSS diminuíram o comprimento do cólon. Todavia, os diferentes tratamentos não foram capazes de evitar o encurtamento ou recuperar as dimensões naturais do intestino grosso (Figuras 8A-B).

A.

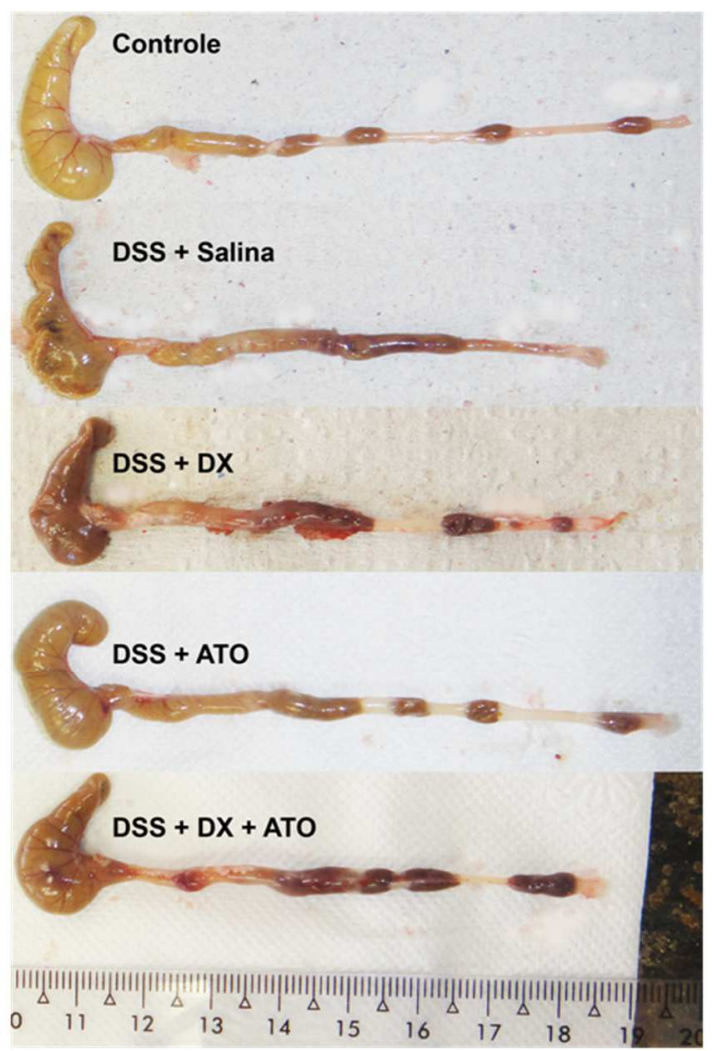

B.

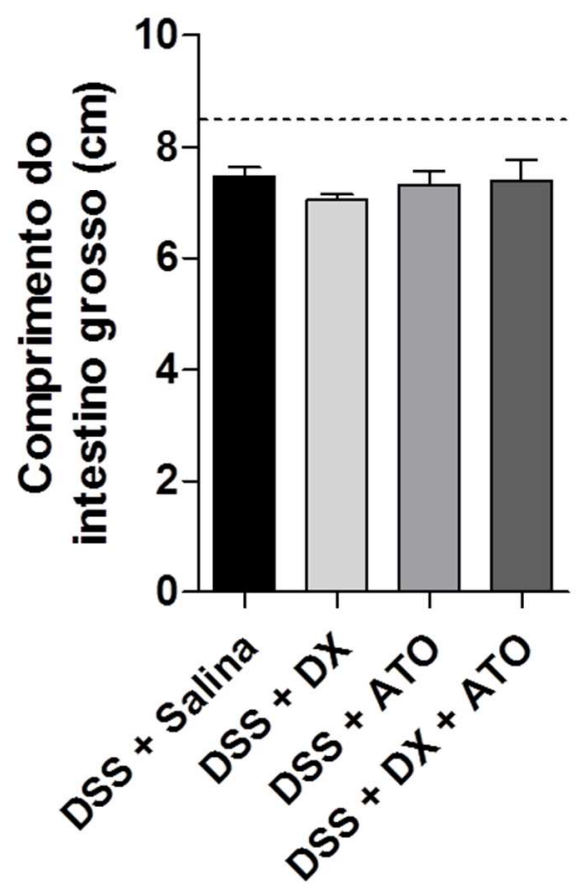

Figura 8. Análise do comprimento do cólon de camundongos submetidos à colite experimental tratados com o veículo (salina), dexametasona (DX) ou atorvastatina (ATO), isoladamente ou em associação. Os camundongos foram expostos por 6 dias à água contendo dextran sulfato de sódio (DSS) $3 \%$ e tratados com doses diárias de DX $1 \mathrm{mg} / \mathrm{kg}$, ATO $10 \mathrm{mg} / \mathrm{kg}$ ou com a associação das drogas, entre os dias $3-5$, contados a partir do início da indução da colite. No $6^{\circ}$ dia, os segmentos intestinais foram cuidadosamente coletados e fotografados. As análises de comprimento foram realizadas por um software apropriado (ImageJ) e o ceco não foi considerado na avaliação. A. Imagens representativas dos cólons. B. Comprimento médio dos fragmentos intestinais em centímetros $(\mathrm{cm})$. Estes dados são representativos de dois experimentos independentes. $n=5$ por grupo. 


\subsection{Avaliação das alterações histopatológicas no cólon após tratamento com dexametasona e atorvastatina}

As análises histológicas mostraram que no grupo saudável a mucosa do intestino grosso apresentou um revestimento epitelial dentro da normalidade, com presença de criptas dispostas em formas retas e paralelas (Figura 9A). A média do número de células encontradas na LP foi de $2916 \pm 123,3$ células $/ \mathrm{mm}^{2}$ (Figura 9F), com predomínio de células mononucleadas, considerada sua população normal. A espessura da mucosa, em $\mu \mathrm{m}$, foi em média 197,3 $\pm 2,1$.

Já no grupo de camundongos expostos ao DSS e tratados com salina foram observadas áreas com ausência de criptas no cólon, intercaladas com áreas de mucosa preservadas (Figura 9B). O epitélio superficial mostrou-se irregular, com achatamento do epitélio e depleção de mucina (ausência de células caliciformes). A mucosa apresentou aumento do infiltrado inflamatório na LP, com número médio de $8908 \pm 191,8$ células $/ \mathrm{mm}^{2}$ (Figura 9F). As células do infiltrado inflamatório foram predominantemente mononucleadas e,

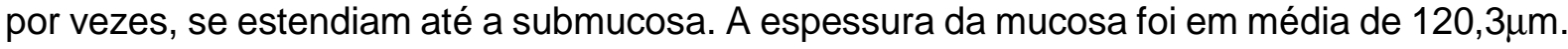

O grupo de animais que receberam DSS e foram tratados com DX isolada exibiu melhora na arquitetura intestinal, mostrando pequenas áreas com ausência de criptas, intercaladas com áreas de mucosa preservadas (Figura 9C). Ainda, a mucosa apresentou, periodicamente, ausência de criptas e/ou anormalidades arquitetônicas, com número médio de células na LP de $5132 \pm 292,9$ células $/ \mathrm{mm}^{2}$ (Figura 9F), diminuída em relação ao grupo doente sem tratamento específico. As células do infiltrado inflamatório também foram predominantemente mononucleadas e, por vezes, se estendiam até a submucosa. A espessura da mucosa foi em média de $120,3 \mu \mathrm{m}$.

Já no grupo DSS tratado com ATO isolada a mucosa mostrou-se mais bem preservada quando comparada aos outros grupos doentes descritos até o momento, apresentando criptas conservadas e infiltrado inflamatório na LP com número médio de $4466 \pm 150,6$ células/mm² 
(Figuras 9D e F). Além disso, as células do infiltrado foram predominantemente mononucleadas e a espessura da mucosa foi em média de $161,3 \mu \mathrm{m}$.

Surpreendentemente, assim como os camundongos tratados com DX, o grupo DSS tratado com a associação de drogas apresentou mucosa também preservada, com criptas conservadas, embora em pequenos focos tenha se observado células caliciformes com achatamento do epitélio e depleção de mucina (Figura 9E). Na LP, a quantificação do infiltrado inflamatório foi de $3792 \pm 195,9$ células $/ \mathrm{mm}^{2}$ (Figura 9F), chegando próximo ao valor encontrado nos animais saudáveis. As células do infiltrado também foram predominantemente mononucleadas e a espessura da mucosa foi, em média, de 153,6 $\mu \mathrm{m}$.

Resumidamente, a terapia com ATO isolada mostrou ser a melhor opção de tratamento por recuperar e/ou preservar as características naturais do epitélio intestinal quando comparados aos outros esquemas terapêuticos. Entretanto, de modo interessante, o tratamento associado de drogas melhorou os aspectos morfométricos do cólon dos animais expostos ao DSS mesmo apresentando um escore pós-morte relativamente alto. Ainda, todas as terapias foram capazes de reduzir o número de células no sítio inflamatório, com a associação de drogas significativamente mais eficiente do que o uso de DX ou ATO isoladas. 
A.

\section{Água + Salina}
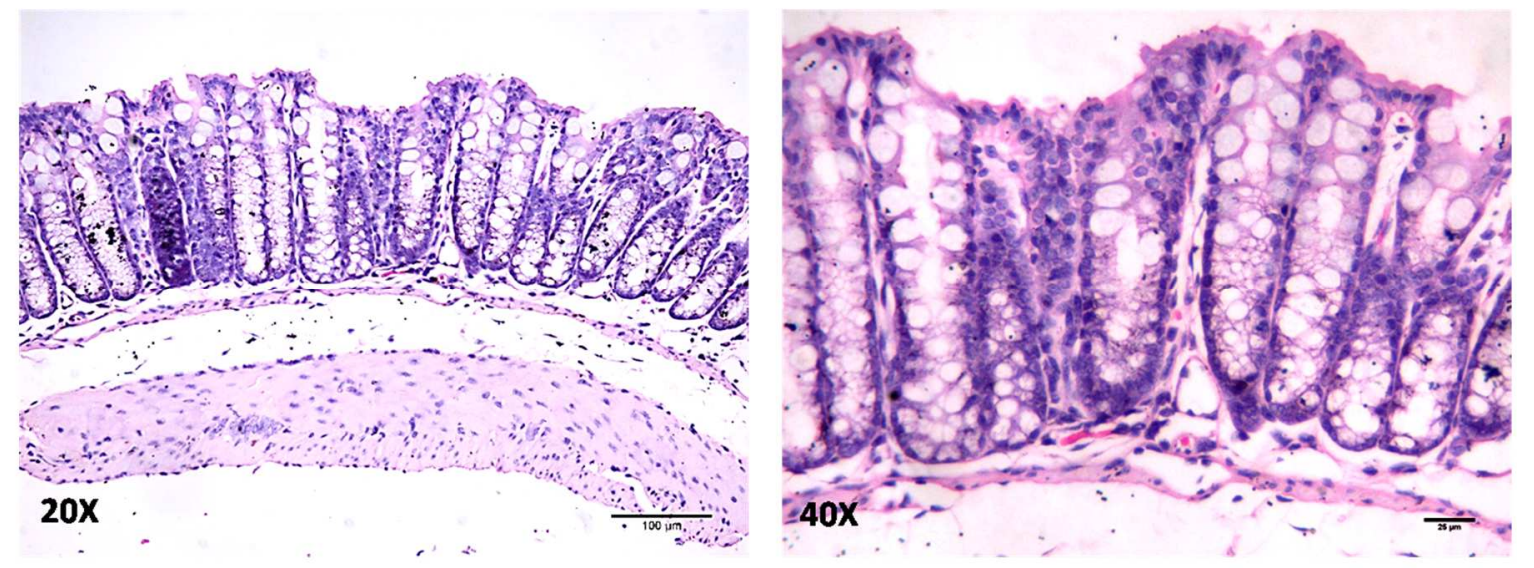

B.

\section{DSS + Salina}
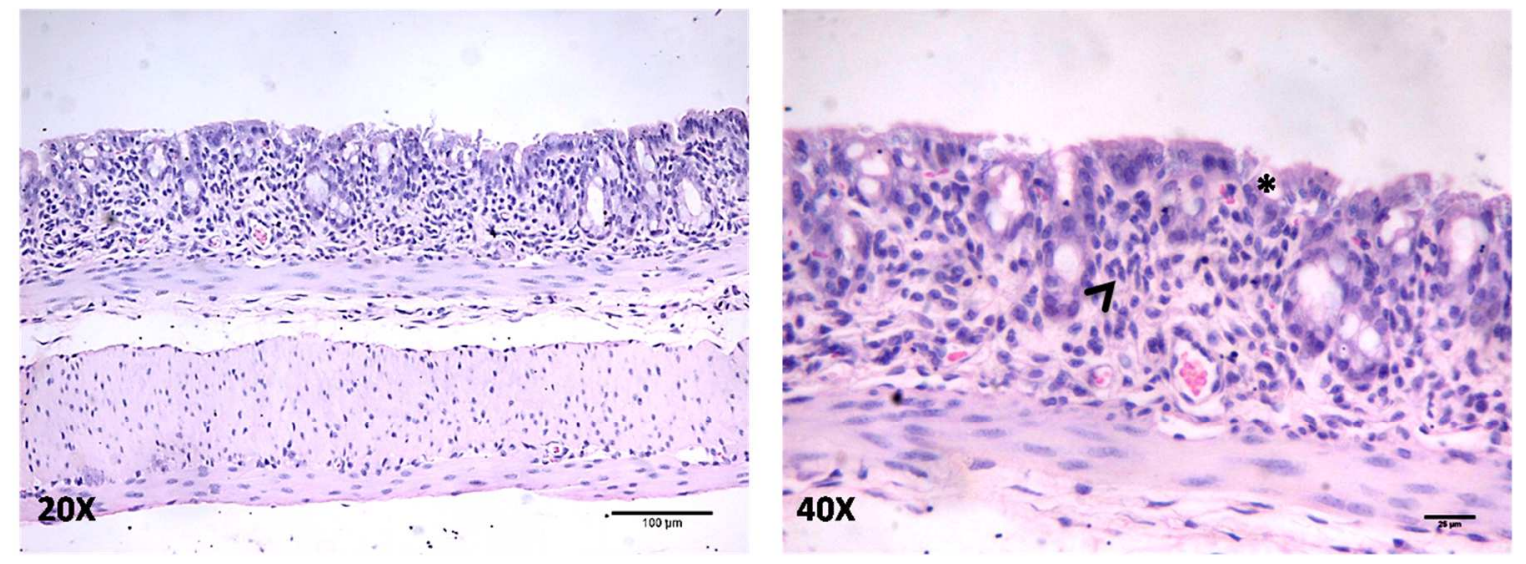

c.

\section{DSS + DX 1mg/kg}
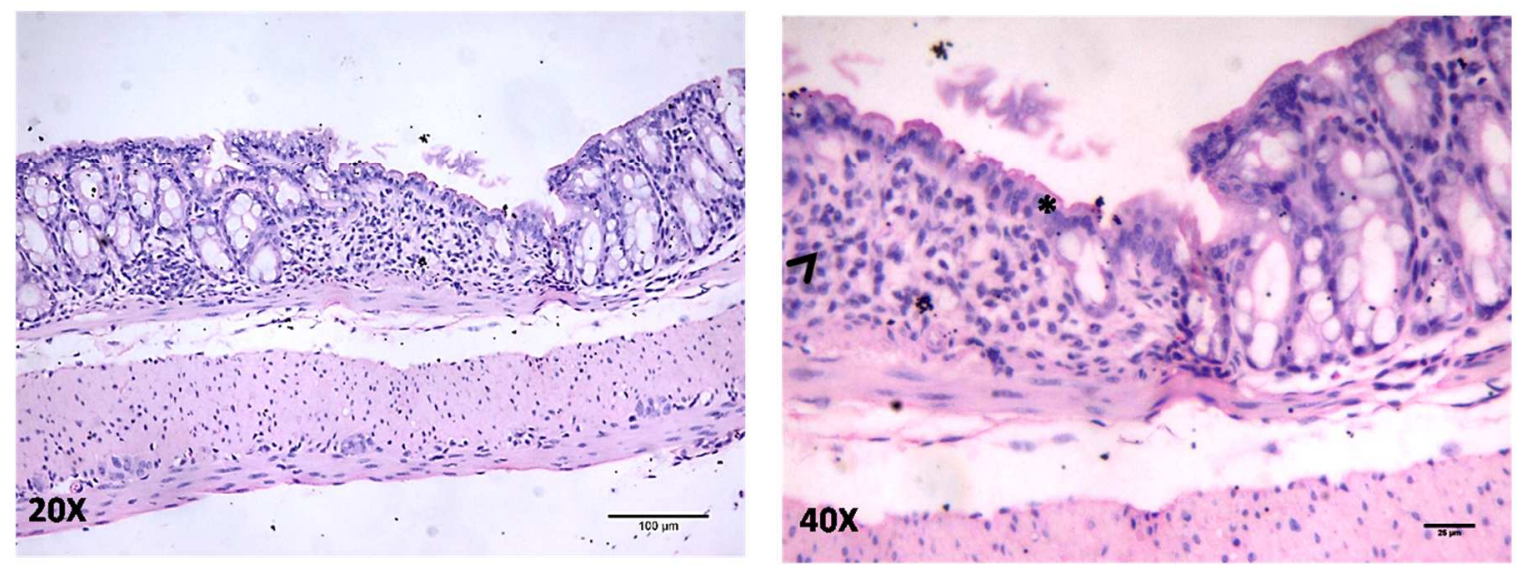
D.

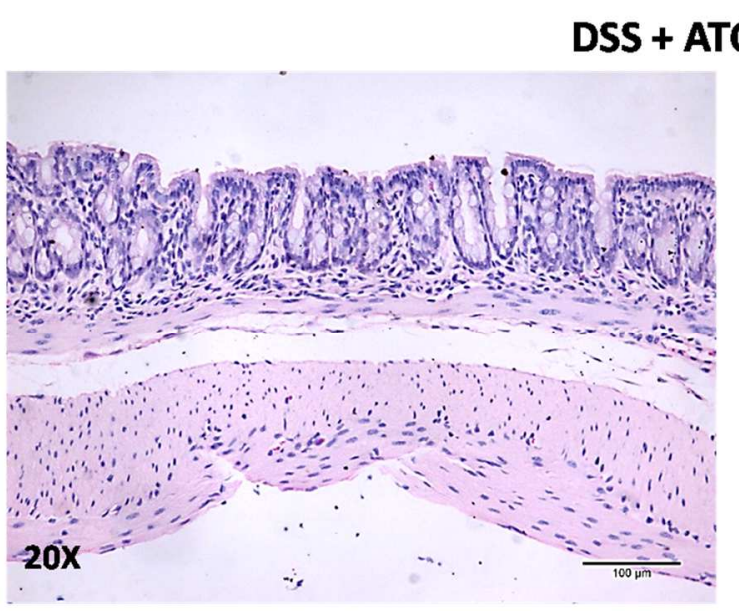

\section{DSS + ATO 10mg/kg}

E.

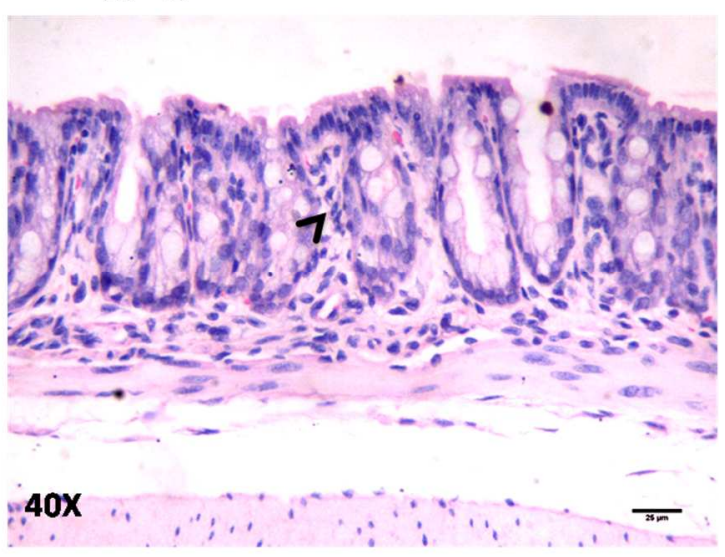

\section{DSS + DX 1mg/kg + ATO 10mg/kg}
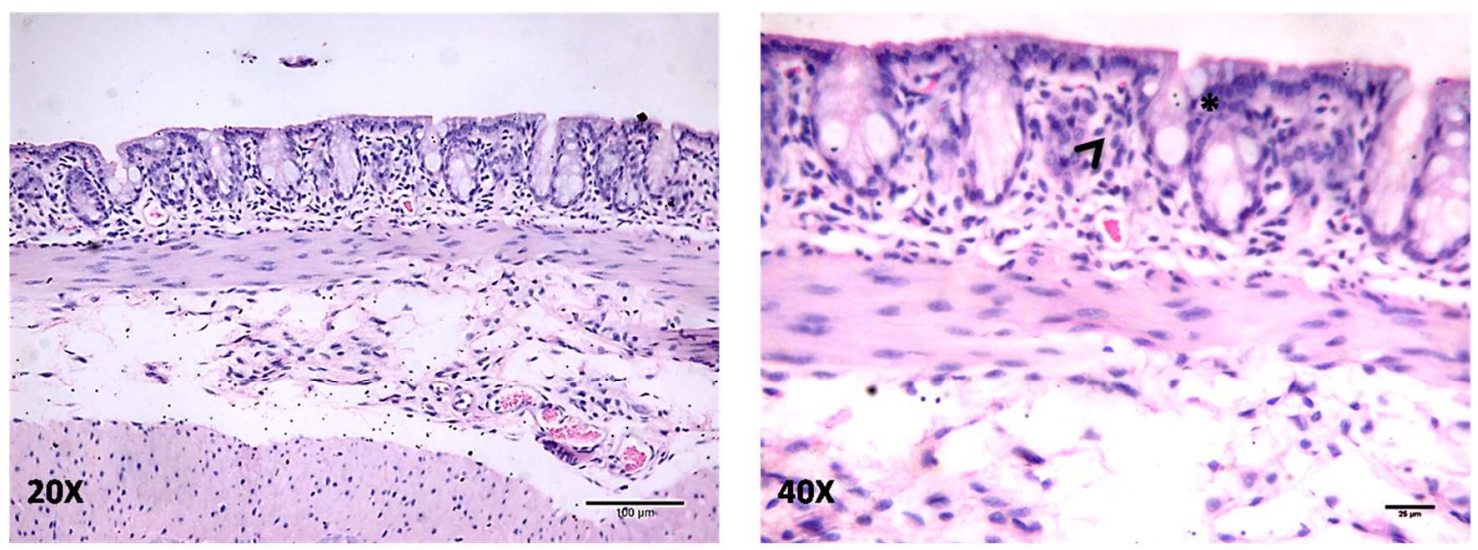

F.

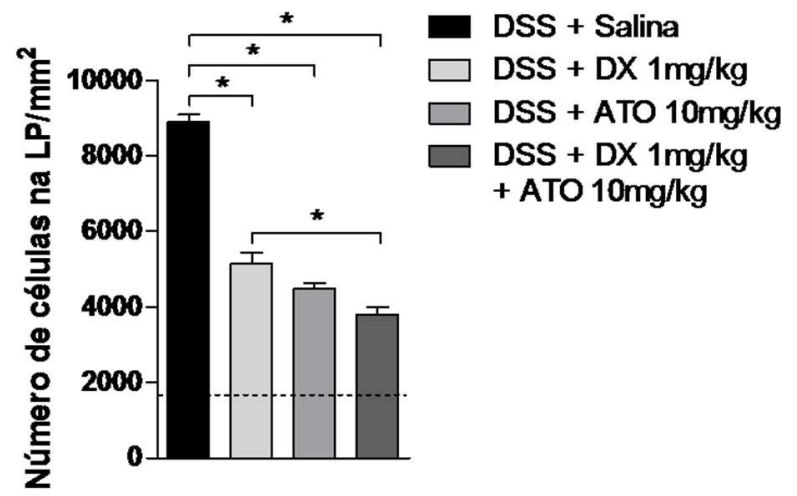

Figura 9. Análise histopatológica do cólon de camundongos expostos a água contendo dextran sulfato de sódio (DSS) $3 \%$, tratados com o veículo (salina), dexametasona (DX) ou atorvastatina (ATO), isoladamente ou em associação. Os camundongos foram expostos por 6 dias ao DSS e tratados com doses diárias de DX $1 \mathrm{mg} / \mathrm{kg}$, ATO $10 \mathrm{mg} / \mathrm{kg}$ ou com a associação das drogas, entre os dias 3-5, contados a partir do início da indução da colite. No $6^{\circ}$ dia, as amostras de cólon foram coletadas fixadas, incluídas em parafina e coradas por hematoxilina e eosina (H\&E). Os animais foram avaliados quanto à arquitetura e o processo inflamatório encontrado nos tecidos. A. Arquitetura normal do cólon. B. Ausência de criptas intestinais e depleção de mucina $\left({ }^{*}\right)$. Hipercelularidade na lâmina própria (LP) e submucosa (cabeça de seta). C. Áreas com ausência de criptas (*). Hipercelularidade moderada na LP e na submucosa (cabeça de seta). D. Hipercelularidade leve na LP (cabeça de seta). E. Pequenos focos de depleção de mucina na mucosa intestinal $\left({ }^{*}\right)$ e hipercelularidade leve na LP (cabeça de seta). As fotomicrografias da coluna esquerda foram obtidas com objetiva de 20x, enquanto 
as da coluna direta foram obtidas com objetivas de 40x. F. Número de células mononucleares na LP por $\mathrm{mm}^{2}$ de tecido. $\mathrm{n}=4-6$ animais por grupo. Estes dados são representativos de dois experimentos independentes.

\subsection{Quantificação de mieloperoxidase, N-acetilglicosaminidase e eosinófilo- peroxidase}

Uma vez que foi observada melhora macroscópica nos intestinos dos animais submetidos à colite experimental tratados com ATO isoladamente e que os efeitos da associação das drogas mostraram-se controversos, buscou-se avaliar se os diferentes tratamentos influenciavam a qualidade do infiltrado local de células inflamatórias, inicialmente da resposta imune inata. Assim, a presença de neutrófilos, macrófagos e eosinófilos foi avaliada de forma indireta através de ensaios de atividade das enzimas mieloperoxidase (MPO), N-acetilglicosaminidase (NAG) e eosinófilo-peroxidase (EPO), respectivamente. Como esperado, constatou-se aumento de pelo menos 2 enzimas (MPO e NAG) no cólon dos animais do grupo DSS sem tratamento específico (Figuras 10A-B). No caso das enzimas EPO, o grupo exposto ao DSS tratado com o veículo apresentou níveis semelhantes de atividade enzimática ao grupo saudável (Figura 10C).

Apesar da alteração da atividade de MPO não ter sido significativa entre os grupos tratados isoladamente ou com a associação de drogas (Figura 10A), uma redução na atividade da NAG foi observada no cólon dos camundongos tratados com DX quando comparado ao grupo de animais doentes tratados com salina (Figura 10B). Entretanto, não houve diferenças nos grupos com uso de estatina isolada ou combinada com DX.

Dessa forma, em geral, as terapias empregadas pareceram não exercer efeitos significativos no acúmulo dessas subpopulações celulares da resposta imune inata no intestino. No entanto, nossos resultados apontam para uma capacidade da DX em diminuir o acúmulo local de macrófagos. 
A.

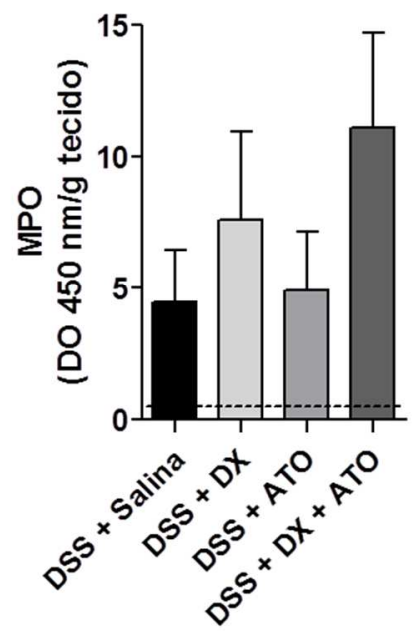

B.

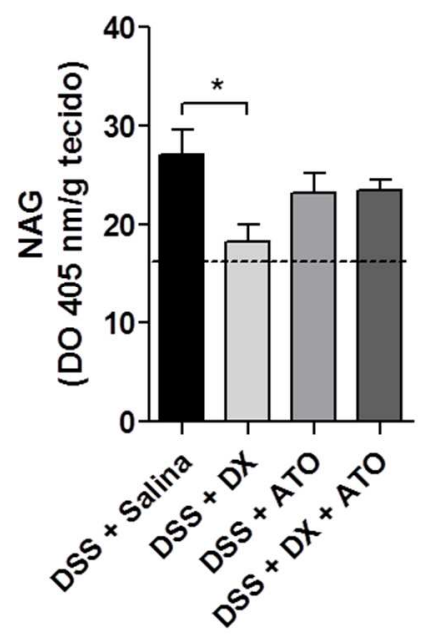

C.

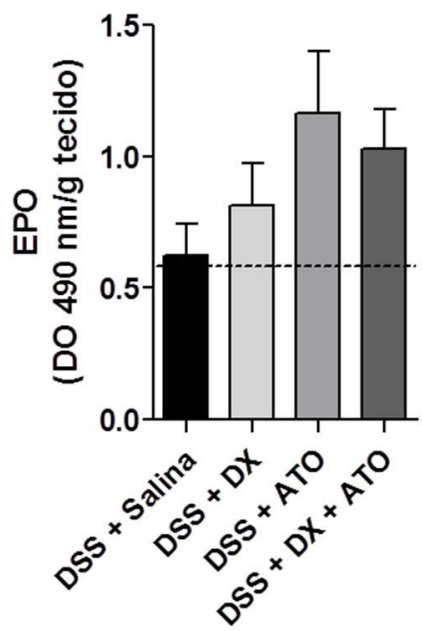

Figura 10. Detecção da atividade das enzimas mieloperoxidase (MPO) (A), Nacetilglicosaminidase (NAG) (B) e eosinófilo-peroxidase (EPO) (C) no cólon de camundongos submetidos à colite experimental, tratados com o veículo (salina), dexametasona (DX) ou atorvastatina (ATO), isoladamente ou em associação. Os camundongos foram expostos por 6 dias à água contendo dextran sulfato de sódio (DSS) $3 \%$ e foram tratados com doses diárias de DX $1 \mathrm{mg} / \mathrm{kg}$, ATO $10 \mathrm{mg} / \mathrm{kg}$ ou com a associação das drogas, entre os dias 3-5, contados a partir do início da indução da colite. A eutanásia foi realizada no dia 6 para coleta e processamento das amostras para os referidos ensaios enzimáticos. Os resultados foram expressos em densidade óptica (DO) corrigidos pelo peso do tecido em gramas $(\mathrm{g})$. As linhas pontilhadas referem-se ao grupo controle saudável tratado com o veículo (salina). Estes dados são representativos de dois experimentos independentes. $n=5$ animais por grupo. ${ }^{*} p<0,05$.

\subsection{Quantificação de leucócitos totais em diferentes tecidos, quantificação de linfócitos intraepiteliais e contagem diferencial de leucócitos}

Além de avaliar os efeitos das terapias sobre subpopulações celulares no local da inflamação, procurou-se também observar se elas influenciavam o número de leucócitos circulantes, bem como em órgãos linfoides secundários (baço e linfonodos mesentéricos LNM), na LP e a quantidade de linfócitos intraepiteliais (LIE).

A análise da quantificação de leucócitos totais do sangue periférico mostrou que DX e ATO, individualmente ou em associação, diminuíram o número de células circulantes quando comparado ao grupo DSS tratado com salina (Figura 11A). Além disso, a terapia conjunta de DX e ATO causou diminuição significativa de leucócitos em ambos os órgãos linfoides (baço e LNM) quando comparado ao grupo doente sem tratamento específico (Figuras 11B-C). O tratamento isolado com DX também causou redução do número de leucócitos nos LNM de 
camundongos expostos ao DSS, mas essa alteração foi menos pronunciada se comparada àquela causada pela associação de drogas. Já o uso isolado de ATO não alterou o número de leucócitos nos respectivos órgãos.

A avaliação do número de leucócitos presentes na mucosa intestinal de camundongos expostos à água contendo DSS 3\% mostrou tendência para a diminuição dessa população após a terapia combinada (Figura 11D). Todavia, o uso de ATO pareceu reduzir o número de LIE, enquanto que nenhuma alteração foi observada com os outros tratamentos (Figura 11E). 
A.

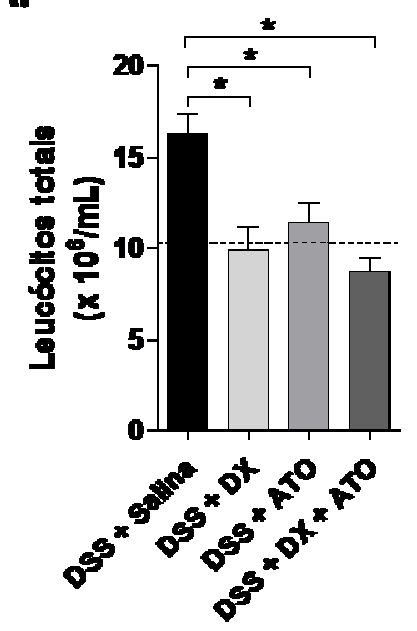

D.

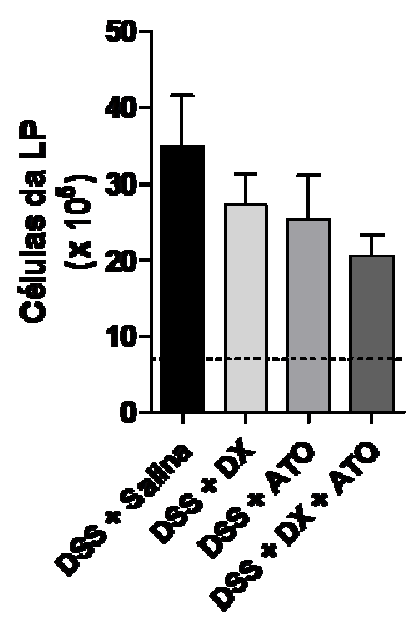

B.

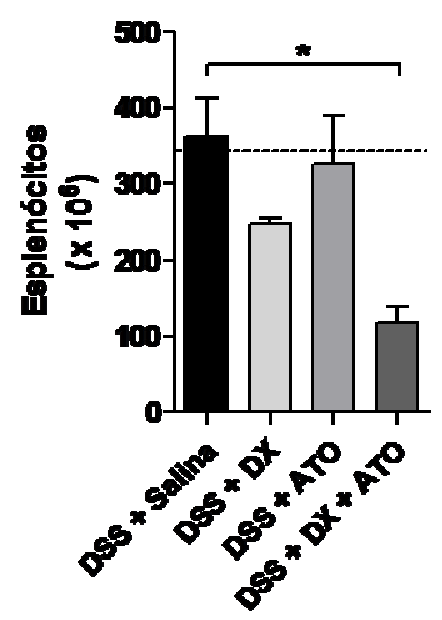

E.

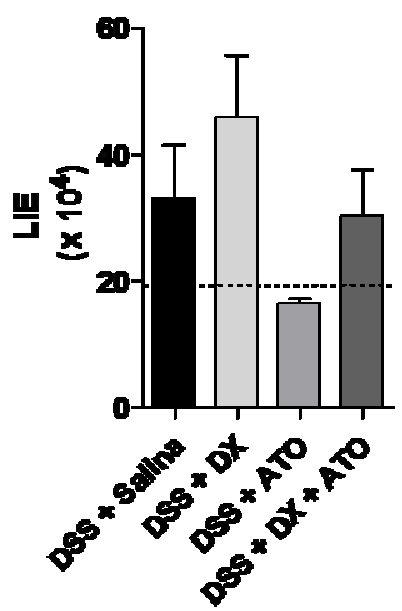

C.

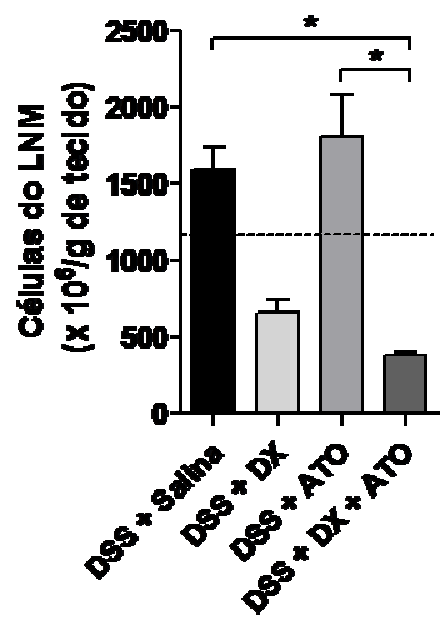

Figura 11. Quantificação de leucócitos no sangue periférico (A), baço (B), linfonodos mesentéricos (LNM) (C), lâmina própria (LP) (D) e linfócitos intraepiteliais (LIE) (E) de camundongos submetidos à colite experimental, tratados com o veículo (salina), dexametasona (DX) ou atorvastatina (ATO), isoladamente ou em associação. Os camundongos foram expostos por 6 dias à água contendo dextran sulfato de sódio (DSS) 3\% e foram tratados com doses diárias de DX $1 \mathrm{mg} / \mathrm{kg}$, ATO $10 \mathrm{mg} / \mathrm{kg}$ ou com a associação das drogas, entre os dias 3-5, contados a partir do início da indução da colite. No $6^{\circ}$ dia os animais foram devidamente eutanasiados, as células extraídas e quantificadas em hemocitômetro. A. Contagem total de leucócitos no sangue periférico; resultados expressos em número de células por $\mathrm{mL}$ de sangue. B. Contagem total de leucócitos no baço; resultados expressos em número total de células no órgão. C. Contagem total de leucócitos no LNM; resultados expressos em número de células corrigido pelo peso do tecido em gramas (g). D-E. Contagem total de leucócitos. As linhas pontilhadas referem-se ao grupo controle saudável tratado com o veículo (salina). Estes dados são representativos de três experimentos independentes para a contagem de leucócitos totais e dois experimentos independentes para os demais. $n=5$ animais por grupo. ${ }^{*} p<0,05$.

Uma vez que o número de leucócitos circulantes foi alterado após o uso de todos os tratamentos farmacológicos, realizou-se a contagem diferencial para saber se alguma subpopulação leucocitária foi preferencialmente afetada. A análise da frequência de leucócitos circulantes no sangue periférico mostrou que o tratamento combinado de DX e ATO aumentou 
a população de neutrófilos, mas não causou alteração nos outros tipos celulares (Figuras 12AD). Os tratamentos isolados não causaram alterações significativas na frequência de células. A multiplicação dos valores da frequência dos subtipos de leucócitos pelo número de leucócitos totais circulantes mostrou que o número total de neutrófilos não foi alterado com as diferentes terapias (Figura 12E). No entanto, os números de linfócitos e monócitos circulantes diminuíram significativamente quando os tratamentos continham DX ou ATO, respectivamente (Figuras 12F-G). Os tratamentos não exerceram influência significativa sobre o número de eosinófilos no sangue periférico de camundongos doentes, mas o tratamento isolado com ATO pareceu diminuir relativamente o número dessa subpopulação (Figura 12H). 
A.

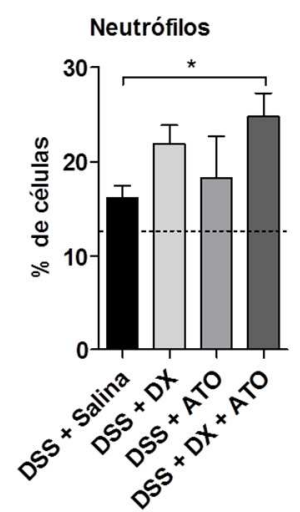

E.

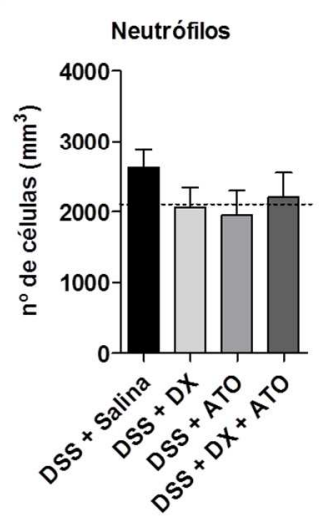

B.

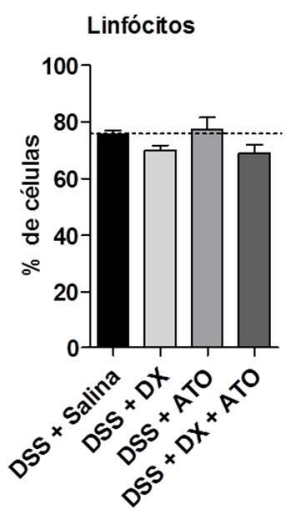

F.

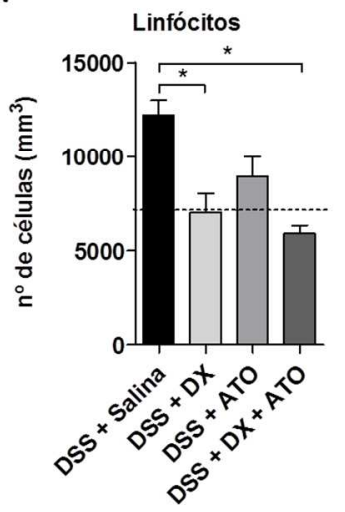

c.

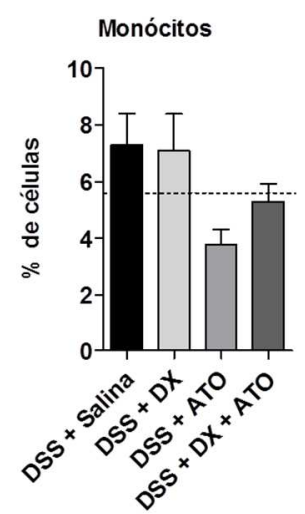

G.

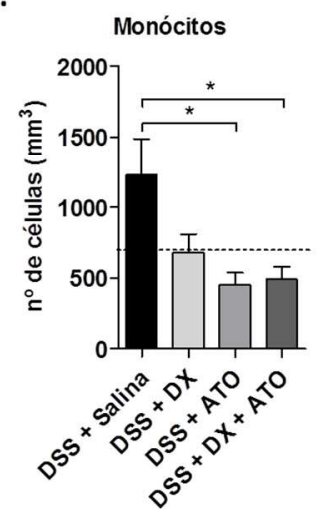

D.

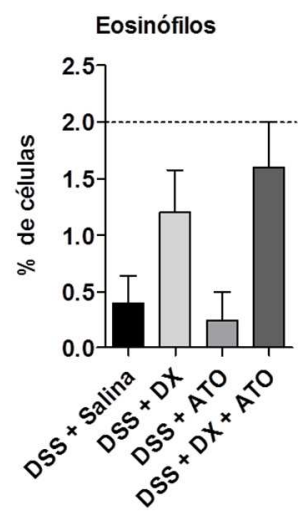

H.

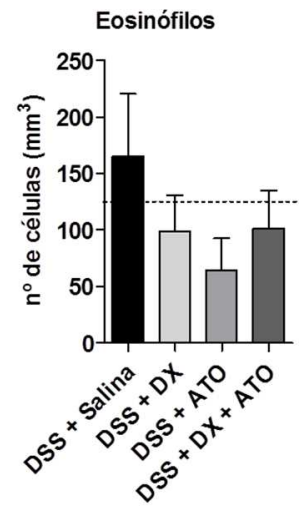

Figura 12. Contagem diferencial de leucócitos circulantes no sangue periférico de camundongos submetidos à colite experimental, tratados com o veículo (salina), dexametasona (DX) ou atorvastatina (ATO), isoladamente ou em associação. Os camundongos foram expostos por 6 dias à água contendo dextran sulfato de sódio (DSS) $3 \%$ e tratados com doses diárias de DX 1mg/kg, ATO $10 \mathrm{mg} / \mathrm{kg}$ ou com a associação das drogas, entre os dias 3-5, contados a partir do início da indução da colite. No $6^{\circ}$ dia os animais foram eutanasiados e o sangue colhido para a realização do esfregaço sanguíneo. A-D. Frequência relativa (\%) de neutrófilos, linfócitos, monócitos e eosinófilos, determinada de acordo com o número das subpopulações de leucócitos computados entre as 100 primeiras células identificadas em microscópio. E-H. Quantidade absoluta de neutrófilos, linfócitos, monócitos e eosinófilos. As linhas pontilhadas referem-se ao grupo controle saudável tratado com o veículo (salina). Estes dados são representativos de três experimentos independentes. $n=5$ animais por grupo. ${ }^{*} p<0,05$.

\subsection{Quantificação de Fas ligante no cólon de animais tratados com dexametasona}

\section{e/ou atorvastatina}

Devido à diminuição da celularidade no cólon dos camundongos expostos ao DSS e tratados com DX e/ou ATO, foi realizado um ensaio para verificar se após os diferentes tratamentos poderia estar ocorrendo aumento na morte celular por apoptose no sítio inflamatório. Para isso, a proteína Fas ligante (Fas-L ou CD178 ou TNFSF6), expressa em diversos tipos celulares (principalmente linfócitos e células NK) e relacionada à indução de morte celular programada, foi determinada no cólon dos animais estudados. Os resultados 
mostraram que camundongos doentes tratados com o veículo apresentaram menor quantidade de Fas-L no local da inflamação do que no intestino de animais saudáveis, inferindo que os mecanismos de morte celular apoptótica parecem estar alterados após exposição ao DSS, resultando em grande acúmulo de células e exacerbando a inflamação (Figura 13). A combinação de DX e ATO elevou a quantidade de Fas-L no cólon dos camundongos expostos ao DSS quando comparados àqueles que receberam o veículo, enquanto que o tratamento individual com DX causou apenas um sutil aumento nas concentrações da proteína. O tratamento com ATO isolada não alterou os níveis de Fas-L. Assim, a diminuição do número de células observada nas análises histológicas após o uso dos tratamentos contendo DX, pode ter sido devido ao aumento dos mecanismos de morte celular apoptótica, enquanto que a redução observada após a terapia com ATO isolada pode ter sido causada por outros mecanismos, incluindo os de morte celular independente de FasL.

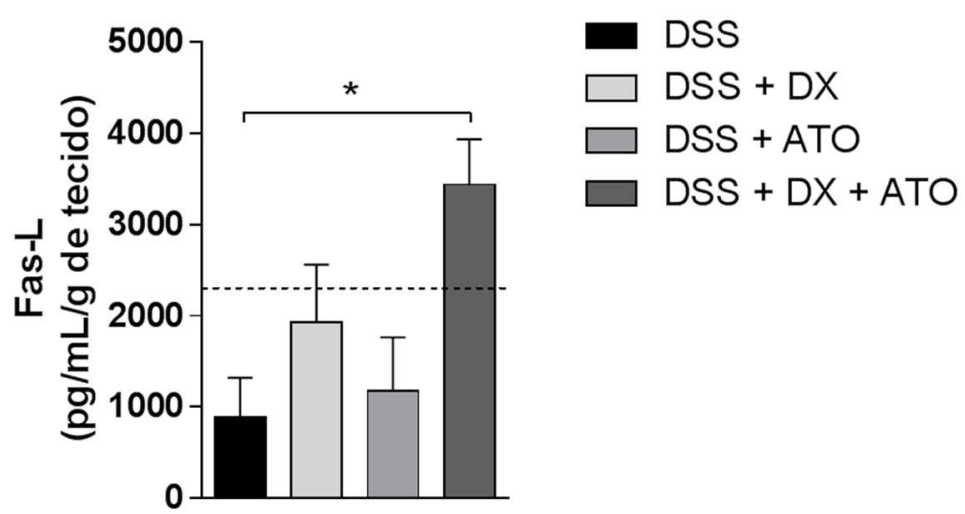

Figura 13. Quantificação da molécula Fas ligante (Fas-L ou CD178 ou TNFSF6) no cólon de camundongos submetidos à colite experimental, tratados com o veículo (salina), dexametasona (DX) ou atorvastatina (ATO), isoladamente ou em associação. As amostras de cólon coletadas no $6^{\circ}$ dia de experimento foram processadas e direcionadas para o ensaio de ELISA. Os resultados foram expressos em $\mathrm{pg} / \mathrm{mL}$ e corrigidos pelo peso do tecido em gramas (g). Estes dados são representativos de um experimento. $n=4$ animais por grupo. ${ }^{*} p<0,05$.

\subsection{Avaliação da expressão de RNAm de moléculas inflamatórias após tratamento}

\section{com dexametasona e atorvastatina}

Uma vez que os tipos e a intensidade das respostas inflamatórias são principalmente coordenados pela ação de citocinas, procurou-se avaliar como o uso de DX e ATO modulava a expressão de RNAm para a síntese dessas moléculas (IL-1ß, TNF, IL-6, IFN-ү, IL-4, IL-17a, 
IL-23 e TGF- $\beta$ ). Além disso, a expressão de moléculas envolvidas no metabolismo de lipidios e com importantes funções na imunidade (PPAR- $\alpha$ e - - $)$ também foi verificada após os tratamentos.

De modo geral, a combinação de GCs e estatinas diminuiu significativamente a expressão de RNAm de IL-1ß e IL-17, resultados estes não alcançados pelas terapias individuais (Figuras 14A e F). Ambas as terapias contendo DX (isolada ou em conjunção com ATO) reduziram os níveis de RNAm de IFN-y (Figura 14D), enquanto que a terapia isolada com ATO diminuiu a expressão da molécula PPAR-Y (Figura14J). Entretanto, os tratamentos não foram capazes de alterar expressivamente os níveis de TNF, IL-6, IL-4, IL23, TGF- $\beta$ e PPAR-a no local da inflamação (Figuras 14B-C, E, G-I).

A.

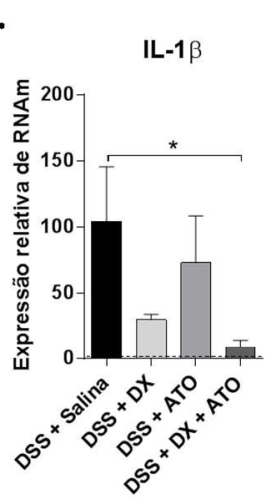

F.

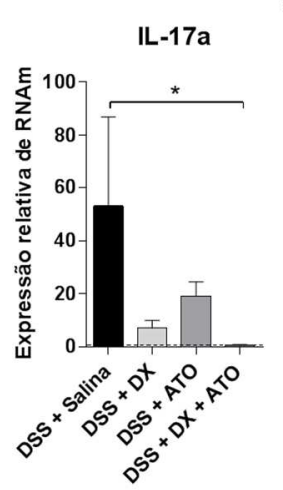

B.

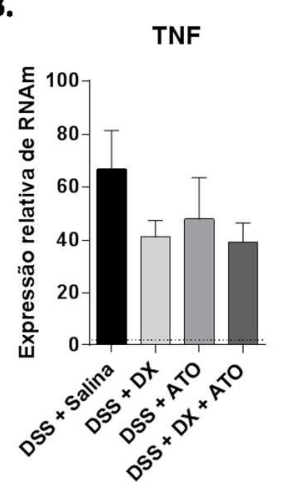

G.

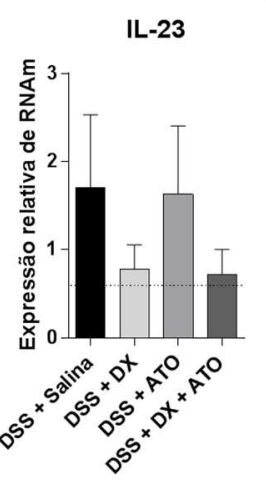

c.

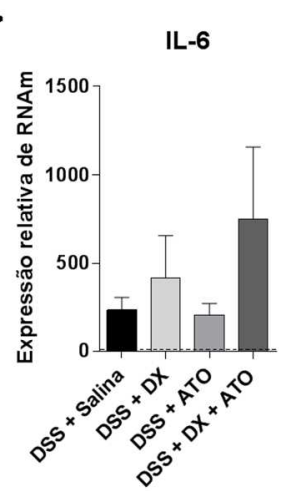

H.

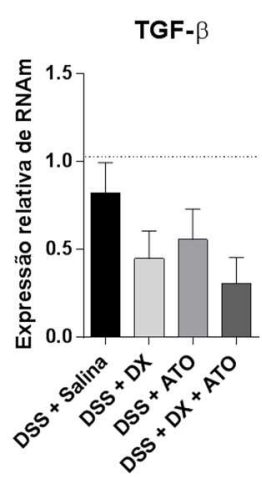

D.

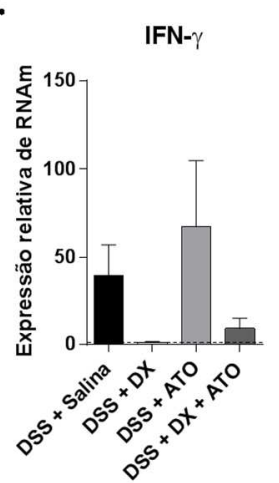

I.

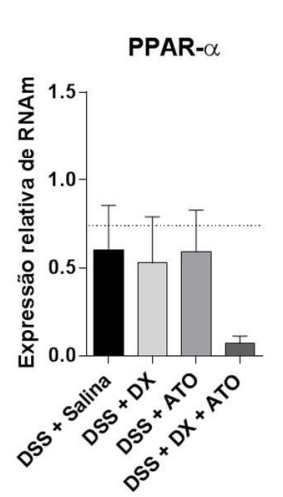

E.

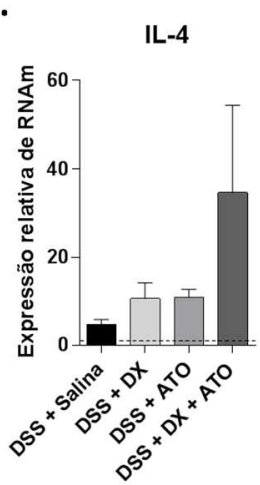

J.

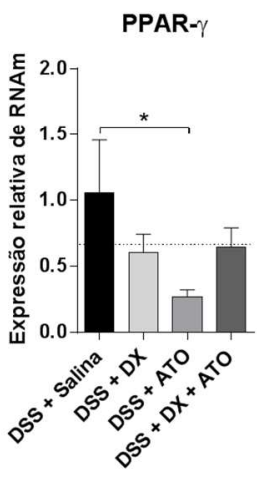

Figura 14. Análise da expressão de RNAm para citocinas, PPAR- $\alpha$ e PPAR-y no cólon de camundongos submetidos à colite experimental, tratados com o veículo (salina), dexametasona (DX) ou atorvastatina (ATO), isoladamente ou em associação. As amostras de cólon coletadas no $6^{\circ}$ dia de experimento foram processadas para a realização de PCR em tempo real. Os resultados foram corrigidos pela $\beta$-actina para normalizar os níveis de expressão dos genes alvos. O número de vezes de expressão diferencial do RNAm foi comparado com o controle (grupo saudável tratado com o veículo) e calculado pela fórmula matemática $2^{-\Delta \Delta \mathrm{Ct}}$. As linhas pontilhadas referem-se ao grupo controle saudável tratado com o veículo (salina). Ct: ciclo limiar; IL: interleucina; IFN: interferon; PPAR: receptores ativados por proliferadores de peroxissomo; TNF: fator de necrose tumoral Estes dados são representativos de dois experimentos independentes. $n=5$ animais por grupo. ${ }^{*} p<0,05$. 


\subsection{Perfil fenotípico de macrófagos, células dendríticas, células NK, células NKT e linfócitos $\mathrm{T}$ nos diferentes órgãos após tratamento com dexametasona e atorvastatina}

Com o intuito de caracterizar as células do sistema imune na colite experimental após os tratamentos com DX e ATO foi realizada a imunofenotipagem das subpopulações presentes nos órgãos linfoides secundários (baço e LNM) e no cólon. Para isso, as células foram extraídas dos respectivos órgãos e marcadas com anticorpos específicos acoplados a fluorocromos. Como o objetivo dessa análise foi compreender globalmente quais populações leucocitárias eram afetadas pelas diferentes terapias, marcadores celulares genéricos foram utilizados para caracterizar as distintas populações que compõem o sistema imune.

A frequência de células $\mathrm{CD}_{11} \mathrm{~b}^{+}$(supostamente macrófagos) de camundongos expostos ao DSS sem tratamento específico não foi alterada nos LNM, mas aumentou expressivamente no baço e LP comparada à de animais saudáveis (15B-D). Considerando os diferentes tratamentos, todos causaram aumento significativo na frequência de células $\mathrm{CD}_{11 \mathrm{~b}^{+}}$no baço, sendo que na terapia de DX e ATO associada este aumento foi expressivamente maior quando comparado às terapias isoladas (Figura 15B). Em contrapartida, houve diminuição na LP, especialmente após a terapia associada (Figura 15D). 
A.

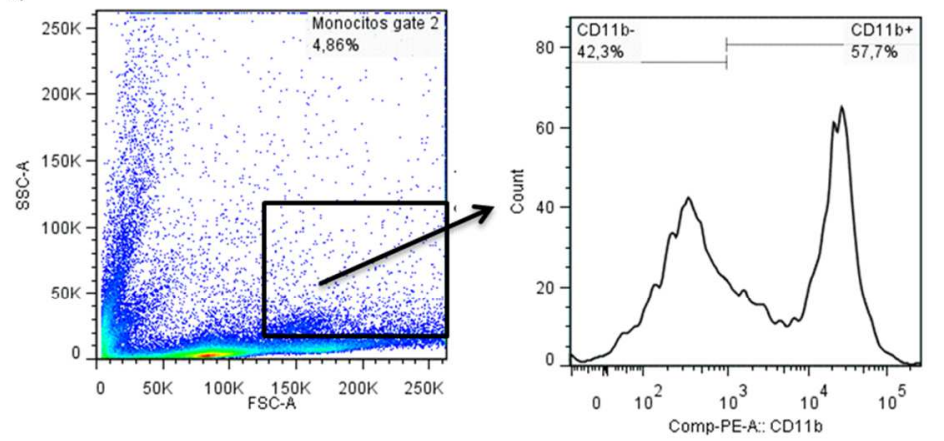

Baço

B.

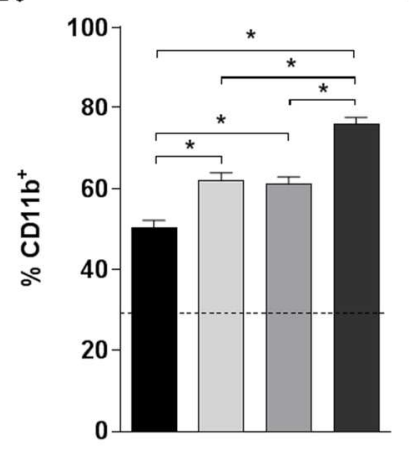

C.

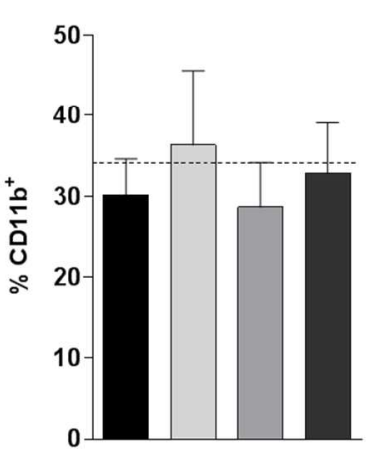

D.

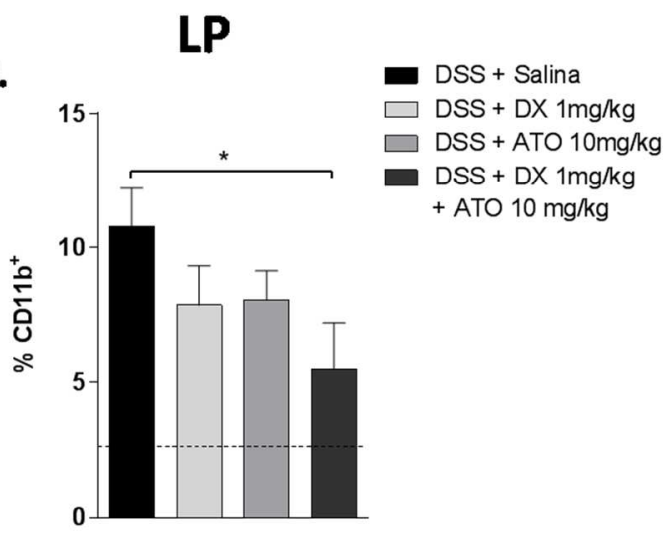

Figura 15. Imunofenotipagem de células $C^{2} 11 b^{+}$no baço, linfonodos mesentéricos (LNM) e lâmina própria (LP) do cólon de camundongos submetidos à colite experimental pelo consumo de água contendo dextran sulfato de sódio (DSS) $3 \%$, tratados com o veículo (salina), dexametasona (DX) ou atorvastatina (ATO), isoladamente ou em associação. Após o período de experimento ( 6 dias), as células foram obtidas dos respectivos órgãos e identificadas por citometria de fluxo através de anticorpos acoplados à fluoróforos específicos para os marcadores estudados. Para a análise, as células foram inicialmente separadas por tamanho e granulosidade e, posteriormente, foi realizada uma seleção (gate) nas populações celulares com características de monócitos/macrófagos. A frequência foi determinada pela porcentagem dentro da gate dessas populações. A. Estratégia de gate. B-D. Frequência (\%) de células $\mathrm{CD}_{11} \mathrm{~b}^{+}$(supostamente macrófagos). Estes dados são representativos de dois experimentos independentes. $n=5$ animais por grupo. ${ }^{*} p<0,05$.

A quebra da barreira intestinal após exposição ao DSS também alterou a frequência de células CD11b-CD11 $c^{+}$e $C D 11 b^{+} C D 11 c^{+}$(supostamente DCs) (Figuras 16A-G). Células CD11b-CD11c ${ }^{+}$não foram encontradas no baço após o tratamento com ATO individual ou combinado com DX, mas estavam presentes e aumentadas no LNM e LP, sendo que neste último sítio o aumento causado pela terapia combinada foi significativamente maior que os grupos doentes sem tratamento e tratados apenas com DX (Figuras 16B-D). Já a frequência de DCs CD11 b+CD11c no baço foi diminuída apenas após o uso associado de ATO e DX, 
não sofrendo alteração significativa nos outros órgãos com os diferentes tratamentos (Figuras $16 \mathrm{E}-\mathrm{G})$.

Resumidamente, os tratamentos contendo ATO diminuíram a frequência de células com características de macrófagos na LP, mas aumentaram no baço. Além disso, as mesmas terapias reduziram DCs $C^{2} 11 b^{-} C D 11 c^{+}$no baço. Entretanto, a terapia com ATO isolada elevou a frequência de DCs CD11b-CD11c ${ }^{+}$nos LNM, enquanto que a combinação de DX e ATO elevou essa população na LP, além de diminuir DCs CD11 b+CD11c no baço.

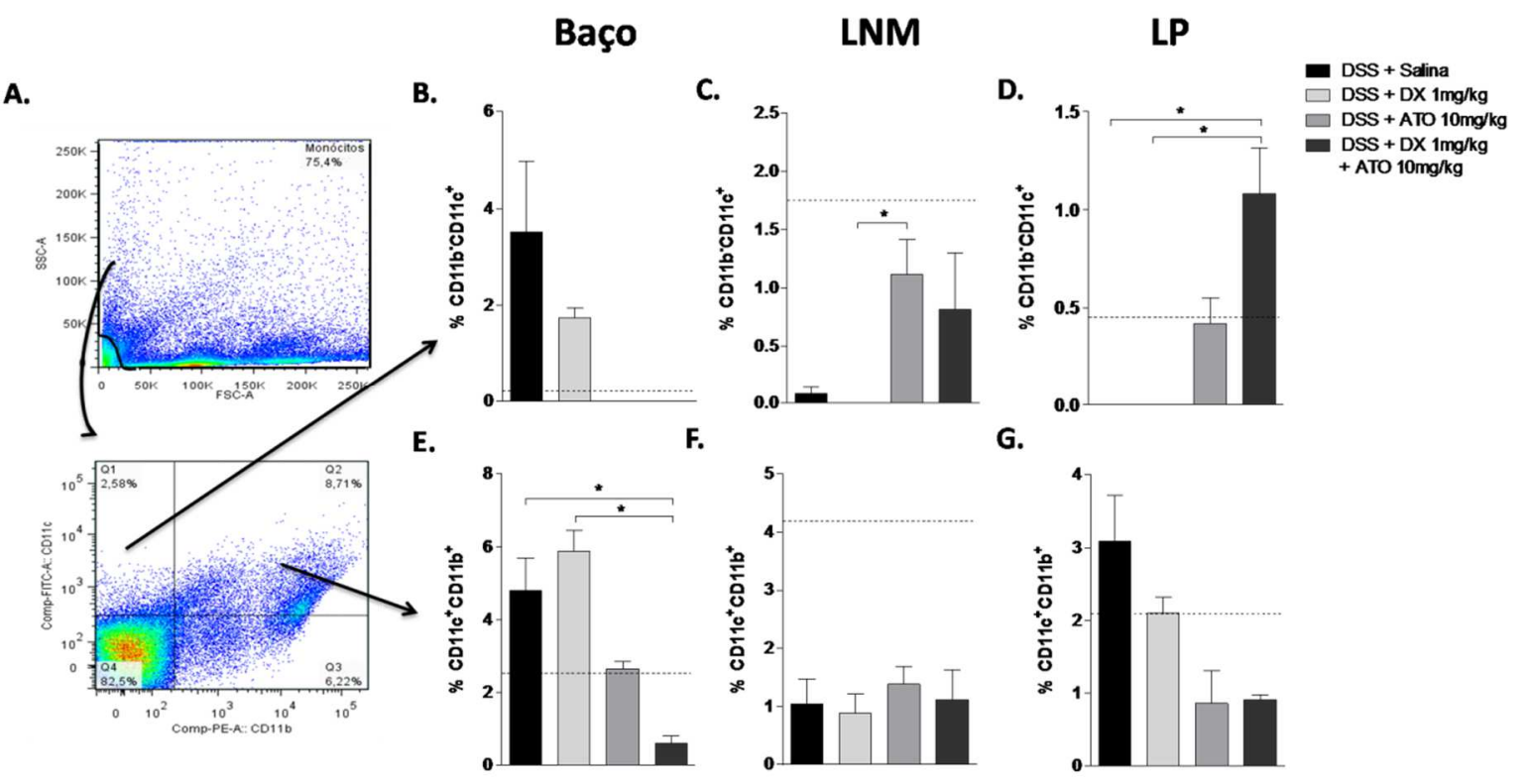

Figura 16. Imunofenotipagem de células $C D 11 b-C D 11 c^{+}$e $C D 11 b^{+} C D 11 c^{+}$de baço, linfonodos mesentéricos (LNM) e lâmina própria (LP) do cólon de camundongos submetidos à colite experimental pelo consumo de água contendo dextran sulfato de sódio (DSS) $3 \%$, tratados com o veículo (salina), dexametasona (DX) ou atorvastatina (ATO), isoladamente ou em associação. Após o período de experimento (6 dias), as células foram obtidas dos respectivos órgãos e identificadas por citometria de fluxo através de anticorpos acoplados à fluoróforos específicos para os marcadores estudados. Para a análise, as células foram inicialmente separadas por tamanho e granulosidade e, posteriormente, foi realizada uma seleção (gate) ampla nas populações celulares, de modo a também incluir as DCs de origem linfoide nas análises. A frequência foi determinada pela porcentagem dentro da gate dessas populações. A. Estratégia de gate. B-D. Frequência (\%) de células CD11b-CD11 ${ }^{+}$ (supostamente DCs). E-G. Frequência (\%) de células CD11b+CD11 $\mathrm{c}^{+}$(supostamente DCs). Estes dados são representativos de dois experimentos independentes. $n=5$ animais por grupo. ${ }^{*} p<0,05$.

A análise dos linfócitos $T$ nos órgãos linfoides secundários mostrou que a terapia concomitante de ATO e DX reduziu as populações $\mathrm{CD}^{+} \mathrm{CD}^{+}$, tanto no baço como nos LNM (Figuras 17B e F). Entretanto, o tratamento combinado aumentou a frequência de células $\mathrm{CD}^{+}{ }^{+} \mathrm{CD} 8^{+}$nos dois órgãos (Figuras $17 \mathrm{C}$ e G). O uso de ATO isolada também aumentou a 
presença de linfócitos $\mathrm{CD}^{+} \mathrm{CD} 8^{+}$no baço e LNM, porém de modo menos expressivo que a terapia associada. Em adição, o uso de DX pareceu exercer pouca influência sobre os linfócitos T, causando alterações pouco expressivas quando comparadas ao grupo de animais doentes que receberam veículo como tratamento.

Considerando as células $\mathrm{CD}^{+}{ }^{+} \mathrm{CD}_{49 b^{+}}$(supostamente NKT) e CD3-CD49b+ (NK), o tratamento com ATO isolada elevou a frequência da segunda população no baço mas não nos LNM (Figura 17E e I). Todavia, de maneira geral, as terapias combinadas ou individuais não exerceram efeitos expressivos na frequência de células NKT (Figuras 17D e H). 
A.

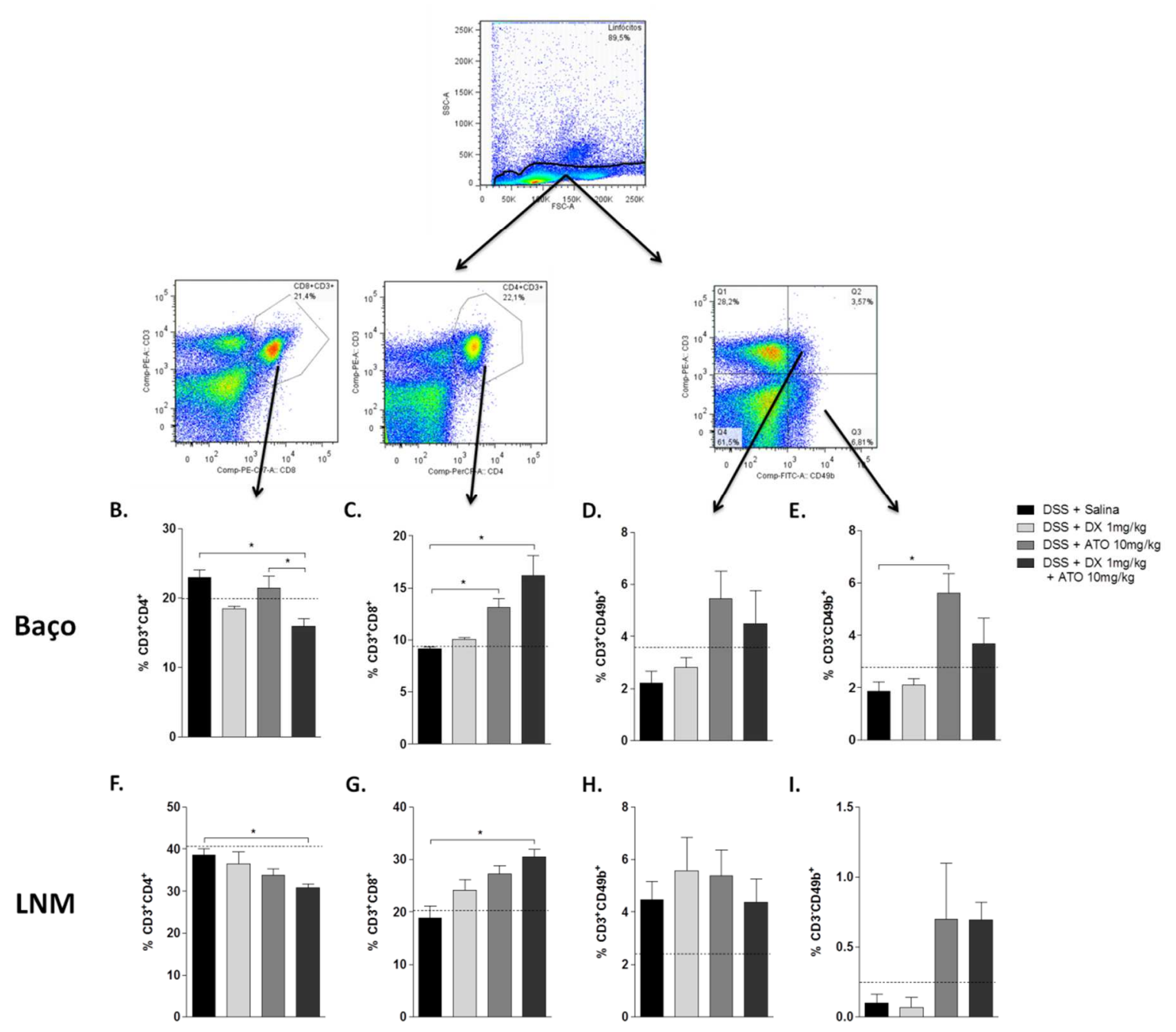

Figura 17. Imunofenotipagem de células de baço e linfonodos mesentéricos (LNM) do cólon de camundongos submetidos à colite experimental pelo consumo de água contendo dextran sulfato de sódio (DSS) $3 \%$, tratados com o veículo (salina), dexametasona (DX) ou atorvastatina (ATO), isoladamente ou em associação. Após o período de experimento (6 dias), as células foram obtidas dos respectivos órgãos e identificadas por citometria de fluxo. Para a análise, as células foram inicialmente separadas por tamanho e granulosidade e, posteriormente, foi realizada uma seleção (gate) nas populações celulares com características de linfócitos. A frequência foi determinada pela porcentagem dentro da gate de linfócitos. A. Estratégia de gate. B-E. Frequência (\%) de linfócitos T $\mathrm{CD}^{+}{ }^{+} \mathrm{CD} 4^{+}(\mathrm{B})$, linfócitos T CD3 ${ }^{+} \mathrm{CD} 8^{+}(\mathrm{C})$, células $\mathrm{CD} 3^{+} \mathrm{CD} 49 \mathrm{~b}^{+}(\mathrm{NKT})(\mathrm{D})$ e células CD3-CD49b+ $(\mathrm{NK})$ (E) no baço. F-I. Frequência (\%) de linfócitos $\mathrm{T} \mathrm{CD3}{ }^{+} \mathrm{CD} 4^{+}(\mathbf{F})$, linfócitos $\mathrm{T} \mathrm{CD} 3^{+} \mathrm{CD} 8^{+}(\mathrm{G})$, células $\mathrm{CD}^{+}{ }^{+} \mathrm{CD}_{49 \mathrm{~b}^{+}}$(supostamente NKT) (H) e células CD3-CD49b+ (NK) (I) nos LNM. Estes dados são representativos de dois experimentos independentes. $n=5$ animais por grupo. ${ }^{*} p<0,05$.

A frequência dos LIE não foi alterada pelo uso das drogas de tratamento, observandose apenas uma pequena redução com o uso de DX isolada ou associada a ATO nos LIE $\mathrm{CD}^{+}{ }^{+} \mathrm{CD} 4^{+}$, porém não significativa (Figuras 18B-C e E). 


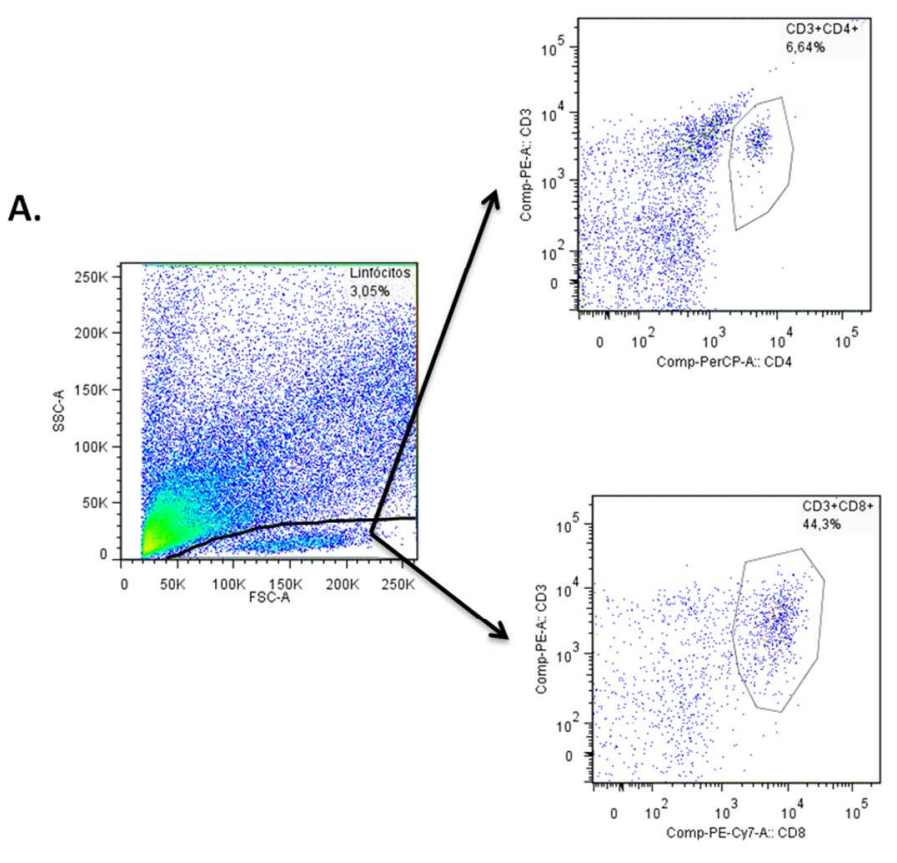

D.

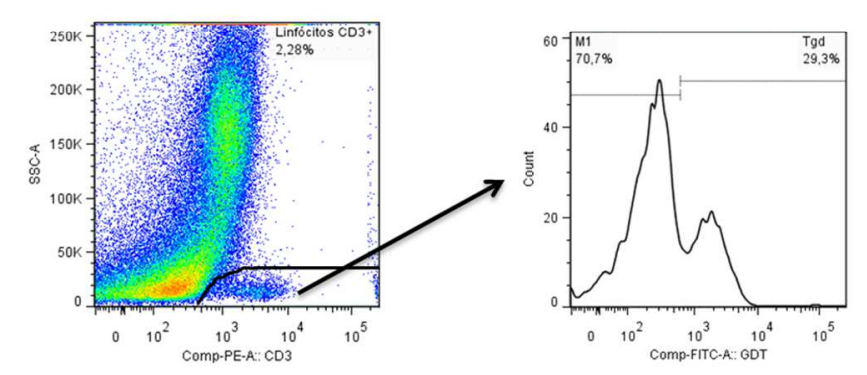

B.

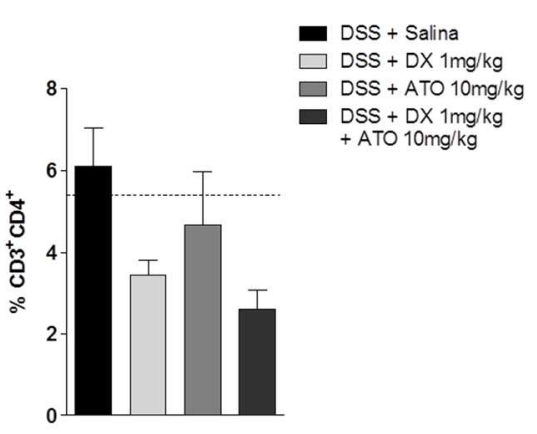

C.

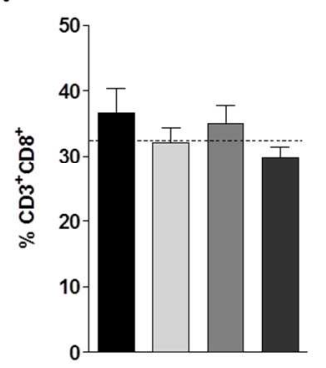

E.

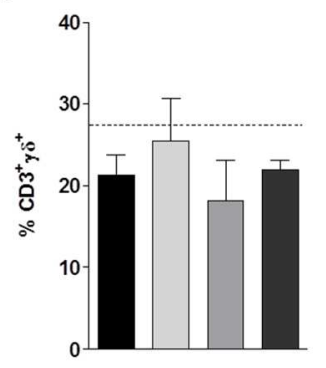

Figura 18. Imunofenotipagem de linfócitos intraepiteliais (LIE) do cólon de camundongos submetidos à colite experimental pelo consumo de água contendo dextran sulfato de sódio (DSS) $3 \%$, tratados com o veículo (salina), dexametasona (DX) ou atorvastatina (ATO), isoladamente ou em associação. Após o período de experimento ( 6 dias), as células foram obtidas dos respectivos órgãos e identificadas por citometria de fluxo através de anticorpos acoplados à fluoróforos específicos para os marcadores estudados. Para a análise, as células foram inicialmente separadas por tamanho e granulosidade e, posteriormente, foi realizada uma seleção (gate) nas populações celulares com características de linfócitos. A frequência foi determinada pela porcentagem dentro da gate de linfócitos. A e D. Estratégia de gate. B, C e E. Frequência (\%) de LIE CD3+CD4+ (B), LIE CD3+CD8+ (C) e LIE Tүס (C). Estes dados são representativos de um experimento. $n=5$ animais por grupo. ${ }^{*} p<0,05$.

Já na LP, apenas o tratamento com ATO aumentou a frequência de células $C D 3^{+} C D 4^{+}$, sendo que houve diferença estatística quando comparado ao grupo DSS tratado com DX (Figura 19B). Não houve alteração de células CD3 ${ }^{+} \mathrm{CD} 8^{+}$após o uso de DX e/ou ATO (Figura 19C). 
A.

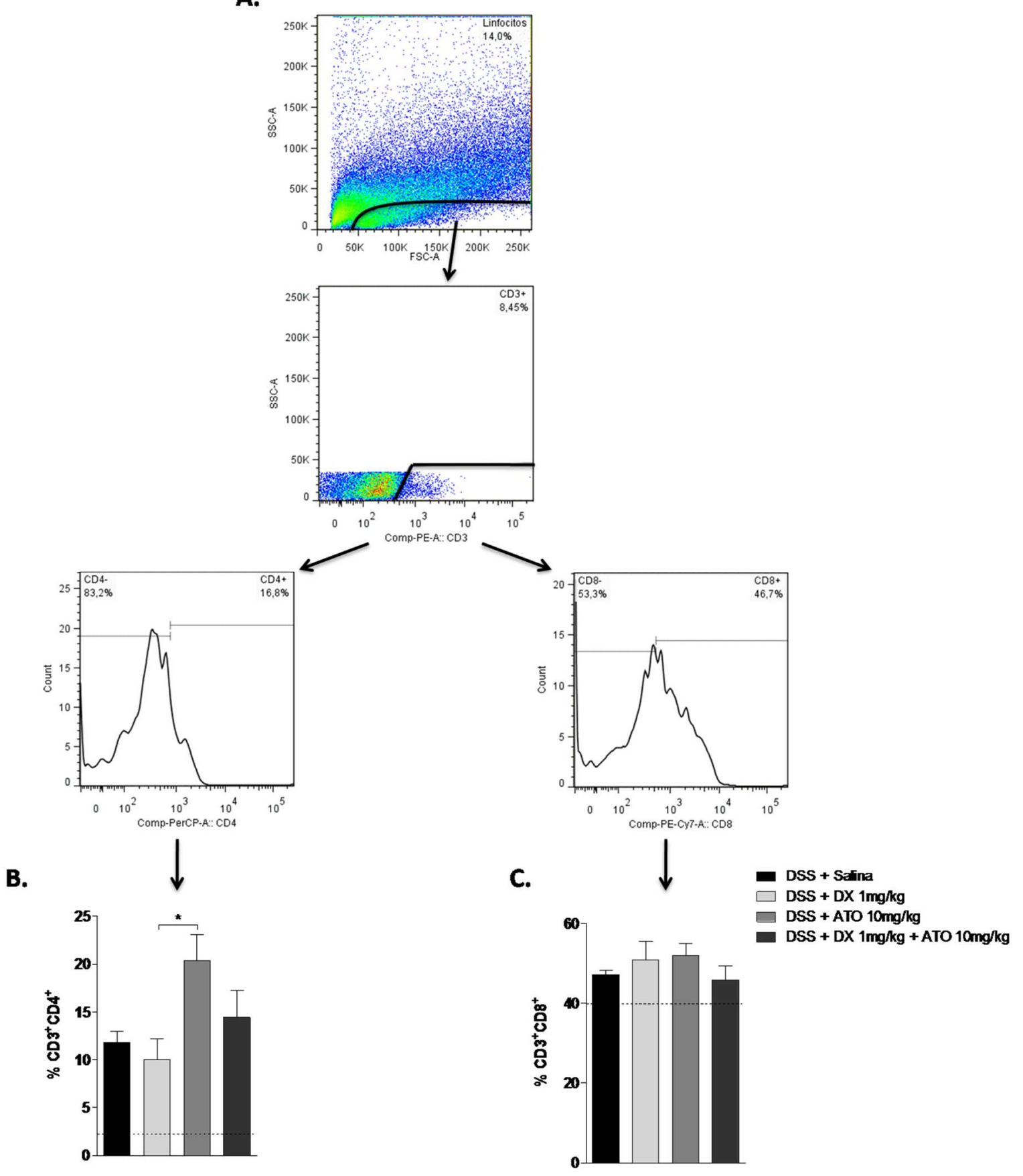

Figura 19. Imunofenotipagem de linfócitos da lâmina própria (LP) do cólon de camundongos submetidos à colite experimental pelo consumo de água contendo dextran sulfato de sódio (DSS) $3 \%$, tratados com o veículo (salina), dexametasona (DX) ou atorvastatina (ATO), isoladamente ou em associação. Após o período de experimento (6 dias), as células foram obtidas dos respectivos órgãos e identificadas por citometria de fluxo. Para a análise, as células foram inicialmente separadas por tamanho e granulosidade e, posteriormente, foi realizada uma seleção (gate) nas populações celulares com características de linfócitos. A frequência foi determinada pela porcentagem dentro da gate de linfócitos $\mathrm{CD}^{+}$. A. Estratégia de gate. B-C. Frequência (\%) de linfócitos T $\mathrm{CD}^{+}{ }^{+} \mathrm{CD} 4^{+}(\mathrm{B})$ e $\mathrm{CD}^{+}{ }^{+} \mathrm{CD} 8^{+}(\mathbf{C})$. Estes dados são representativos de um experimento. $n=5$ animais por grupo. ${ }^{*} \mathrm{p}<0,05$. 


\subsection{Perfil fenotípico de células $\mathrm{T}$ reguladoras após tratamento com dexametasona e atorvastatina}

Uma vez que o controle da inflamação depende do equilíbrio entre células efetoras e mecanismos de regulação da resposta imune, células $\mathrm{T}$ supostamente reguladoras, juntamente com células efetoras $\mathrm{CD}^{+}{ }^{+} \mathrm{CD} 25^{-}$, foram também fenotipadas no baço e LNM de animais expostos ao DSS tratados com DX e/ou ATO. Células CD4 ${ }^{+}$CD25 tiveram sua frequência reduzida no baço após os tratamentos com DX isolada ou em associação com ATO, mas nenhuma alteração foi observada com as diferentes terapias nos LNM (Figura 20A - R1). Além disso, o uso individual ou associado de DX e ATO não alterou a frequência de células CD4+CD25+ nos órgãos linfoides avaliados (Figura 20A - R2).

Parar melhor caracterizar as populações de células Treg, outros marcadores fenotípicos que auxiliam nessa identificação também foram avaliados, incluindo FoxP3, CTLA4, GITR e PD-1. As análises mostraram que a frequência de células $\mathrm{CD} 4^{+} \mathrm{CD} 25^{+} \mathrm{FoxP} 3^{+} \mathrm{e}$ CD4 ${ }^{+}$CD25-PD-1+ aumentou e diminuiu, respectivamente, no baço de camundongos tratados com ATO isolada, mas apenas em comparação ao grupo tratado com DX isolada (Figura 20B - R2; E - R1). Ainda, o tratamento com ATO isolada reduziu a frequência da população $\mathrm{CD}^{+}{ }^{+} \mathrm{CD} 25^{+} \mathrm{PD}-1^{+}$nos $\mathrm{LNM}$ comparado ao grupo doente tratado com o veículo (Figura 20E $\mathrm{R} 2)$.

Resumidamente, as terapias isoladas ou associadas pareceram influenciar pouco a frequência de células T supostamente reguladoras nos órgãos estudados. 
A.

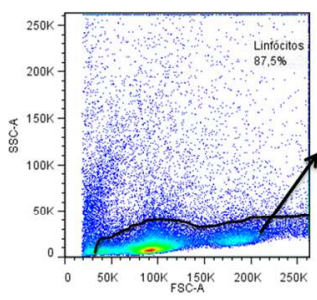

B.

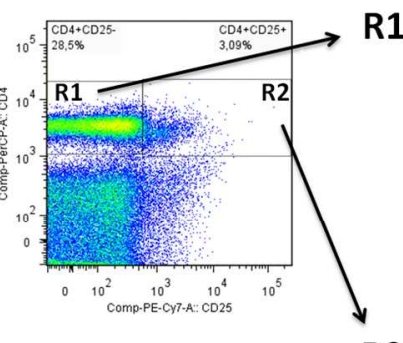

R1

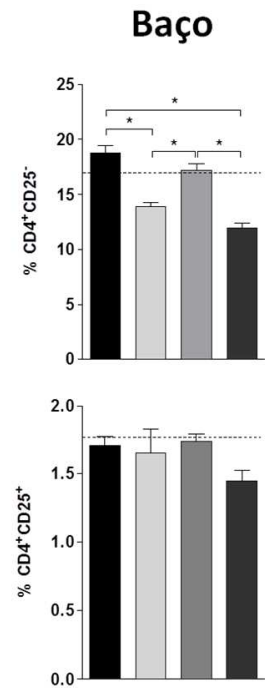

LNM
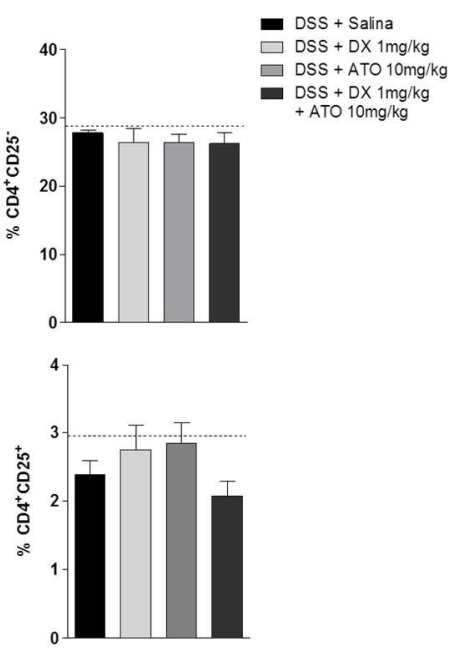

Baço

R1

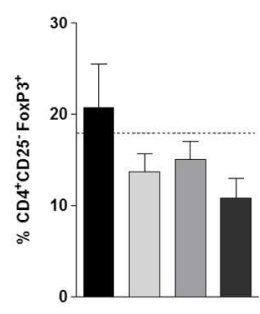

c.

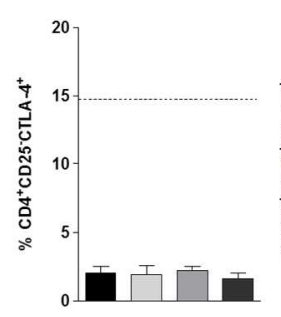

D.

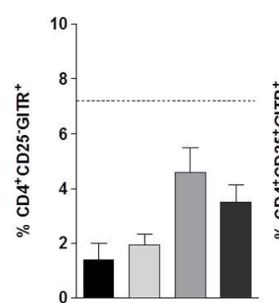

E.
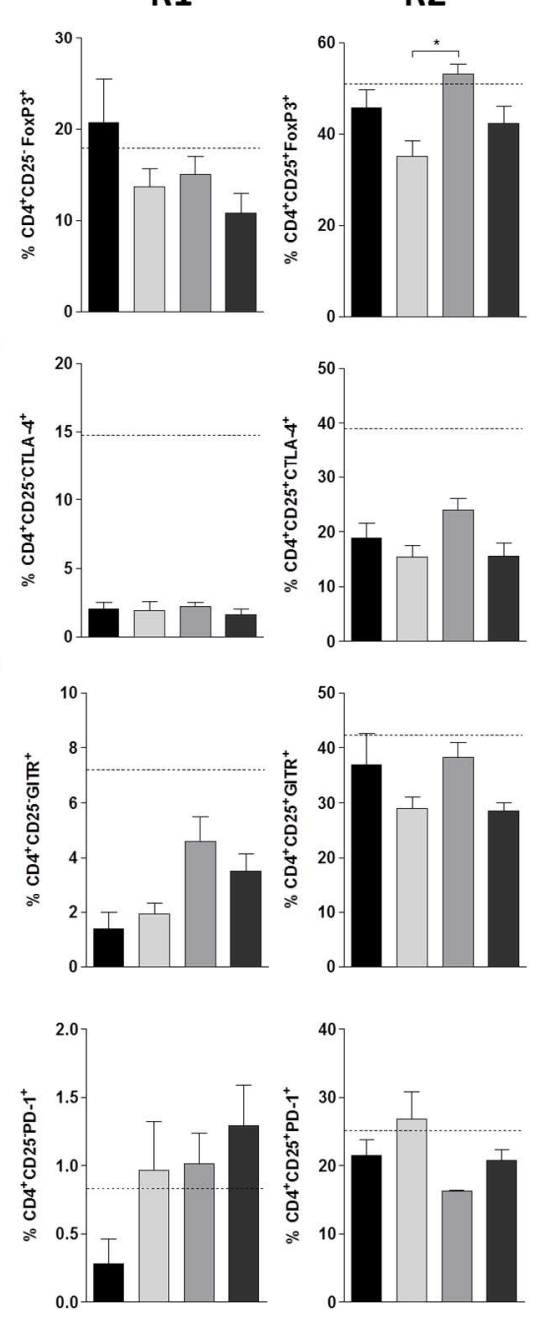

LNM

R1
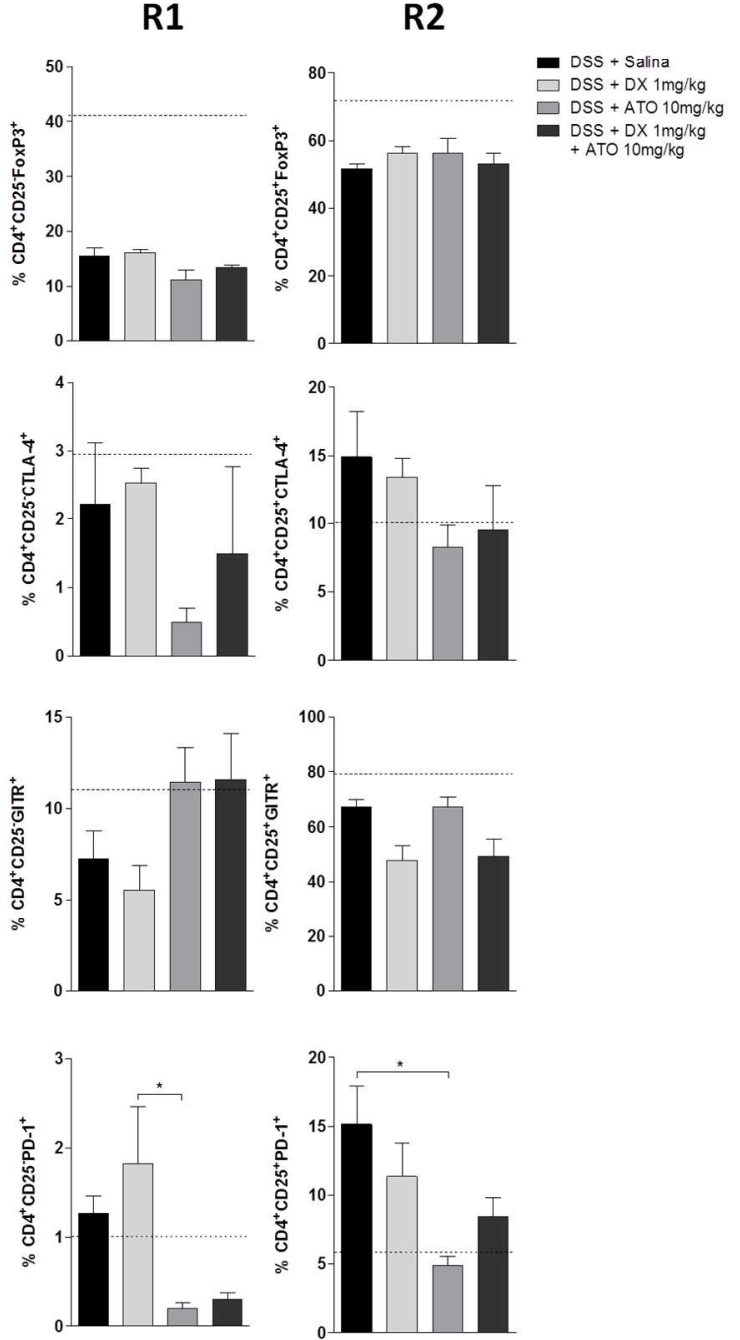

Figura 20. Imunofenotipagem de células $\mathrm{CD}^{+}{ }^{+} \mathrm{CD} 25^{-}(\mathrm{R} 1) \mathrm{CD}^{+} \mathrm{CD} 25^{+}(\mathrm{R} 2)$ no baço e linfonodos mesentéricos de camundongos submetidos à colite experimental pelo consumo de água contendo dextran sulfato de sódio (DSS) $3 \%$, tratados com o veículo (salina), dexametasona (DX) ou atorvastatina (ATO), isoladamente ou em associação. Após o período de experimento (6 dias), as células foram obtidas dos respectivos órgãos e identificadas por citometria de fluxo. Para a análise, as células foram inicialmente separadas por tamanho e granulosidade e, posteriormente, foi realizada 
uma seleção (gate) nas populações celulares com características de linfócitos. A frequência de células $\mathrm{CD}^{+}{ }^{+} \mathrm{CD} 25-(\mathrm{R} 1)$ e $\mathrm{CD} 4{ }^{+} \mathrm{CD} 25^{+}$(R2) foi determinada pela porcentagem dentro da gate de linfócitos, enquanto que para os demais marcadores foi determinada pela porcentagem dentro das gates R1 e R2. A. Estratégia de gate e frequência (\%) de células CD4+CD25- e CD4+CD25+ no baço e LNM. B-E. Frequência (\%) de células $\mathrm{CD} 4^{+} \mathrm{CD} 25^{-}$e $\mathrm{CD} 4^{+} \mathrm{CD} 25^{+}$com identificação de moléculas adicionais que auxiliam na caracterização da população reguladora (FoxP3, CTLA-4, GITR e PD-1). Estes dados são representativos de dois experimentos independentes. $n=5$ animais por grupo. ${ }^{*} p<0,05$.

\subsection{Influência dos tratamentos com dexametasona e atorvastatina na produção de citocinas por células do baço e linfonodos mesentéricos}

Para determinar se os diferentes tratamentos foram capazes de modular a polarização da resposta imune, células de baço e LNM de camundongos submetidos à colite experimental, tratados ou não com as diferentes terapias, foram avaliadas quanto à produção de citocinas intracelulares.

Os resultados mostraram que tanto a ATO isolada como combinada com DX foram capazes de reduzir a frequência de células CD4+IFN-Y+ nos LNM (Figura 21F). Entretanto as terapias não foram capazes de modular a polarização de células CD4+IL-17 ${ }^{+}$, CD4+IL-4+ ou CD4+IL-10+, tanto no baço como nos LNM (Figuras 21B-E; G-I). 
A.

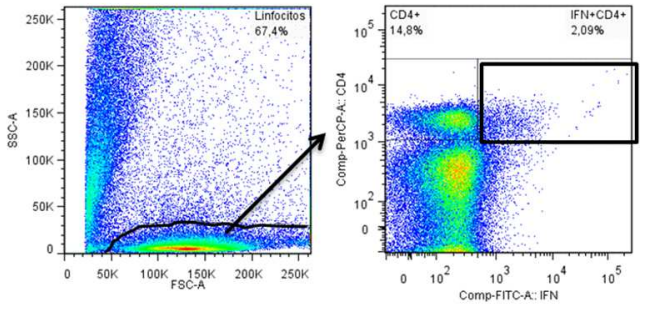

Baço

B.

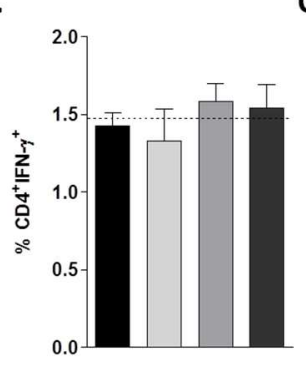

C.

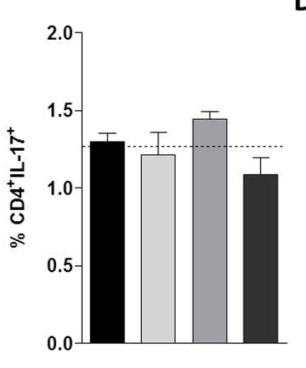

D.

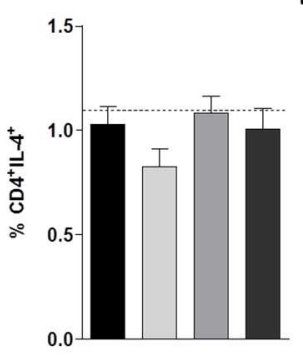

E.

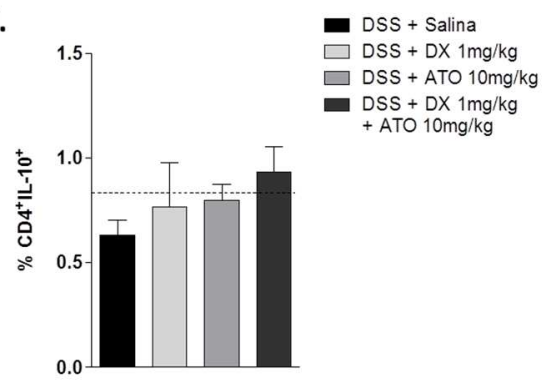

\section{LNM}

F.

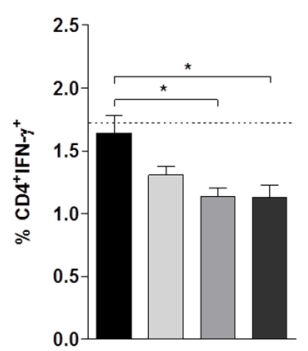

G.

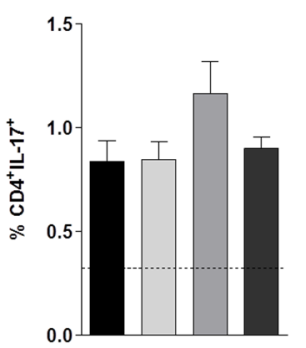

H.

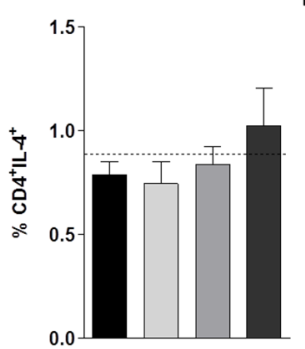

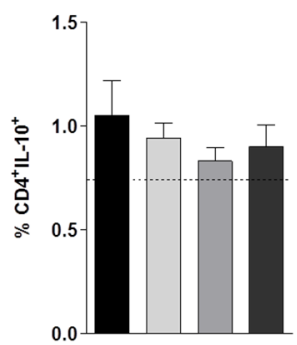

Figura 21. Determinação da produção de citocinas por células $\mathrm{T} \mathrm{CD4}^{+}$do baço e linfonodos mesentéricos (LNM) de camundongos submetidos à colite experimental pelo consumo de água contendo dextran sulfato de sódio (DSS) 3\%, tratados com o veículo (salina), dexametasona (DX) ou atorvastatina (ATO), isoladamente ou em associação. Após o período de experimento (6 dias), as células foram obtidas dos respectivos órgãos, estimuladas com forbol-12-miristato-13-acetato (PMA - $50 \mathrm{ng} / \mathrm{mL})$ e ionomicina $(500 \mathrm{ng} / \mathrm{mL})$ e identificadas por citometria de fluxo. Para a análise, as células foram inicialmente separadas por tamanho e granulosidade e, posteriormente, foi realizada uma seleção (gate) nas populações celulares com características de linfócitos. A frequência foi determinada pela porcentagem dentro da gate de linfócitos. A. Estratégia da gate. B-E. Frequência (\%) de linfócitos CD4+IFN- $Y^{+}$(B), CD4+IL-17+ (C), CD4+IL-4+ (D) e CD4+IL-10+ (E) no baço. F-I. Frequência (\%) de

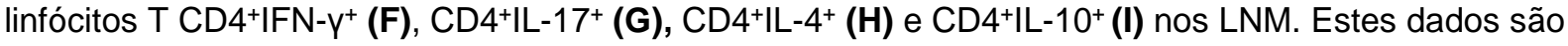
representativos de dois experimentos independentes. $n=5$ animais por grupo. ${ }^{*} p<0,05$.

\subsection{Cultura de esplenócitos e tratamento in vitro com dexametasona e atorvastatina}

Para melhor avaliar o papel dos GCs e estatinas na modulação da resposta imune, foram realizados ensaios in vitro com o intuito de verificar o efeito dessas drogas na proliferação de esplenócitos de camundongos da linhagem C57BL/6 tratados com diferentes 
concentrações e combinações das respectivas drogas. De modo geral, DX e ATO, sozinhas ou combinadas, diminuíram o número da população e a taxa de proliferação das células com características linfocitárias de maneira dose-dependente (Figuras 22A-D). Quando comparadas entre si, ATO mostrou ser mais efetiva do que a DX no que se refere à diminuição da população de linfócitos e à inibição da proliferação celular. Quando as drogas foram associadas, a diminuição na população e proliferação de linfócitos foi ainda mais pronunciada se comparada às ações das drogas separadamente e essa alteração também foi dependente da concentração das drogas utilizadas em combinação. 
A.
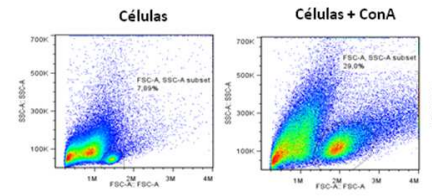

ATO $5 \mu \mathrm{M}$

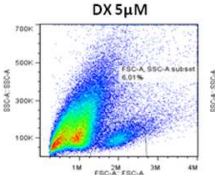

DX $1 \mu M+A T O 5 \mu M$
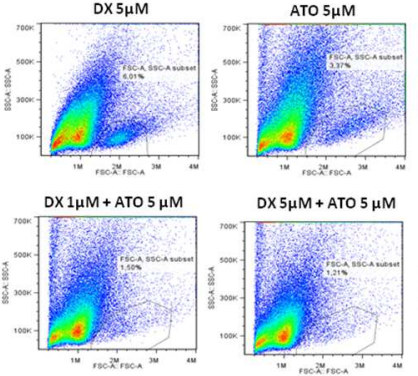

DX $5 \mu \mathrm{M}+$ ATO $5 \mu \mathrm{M}$
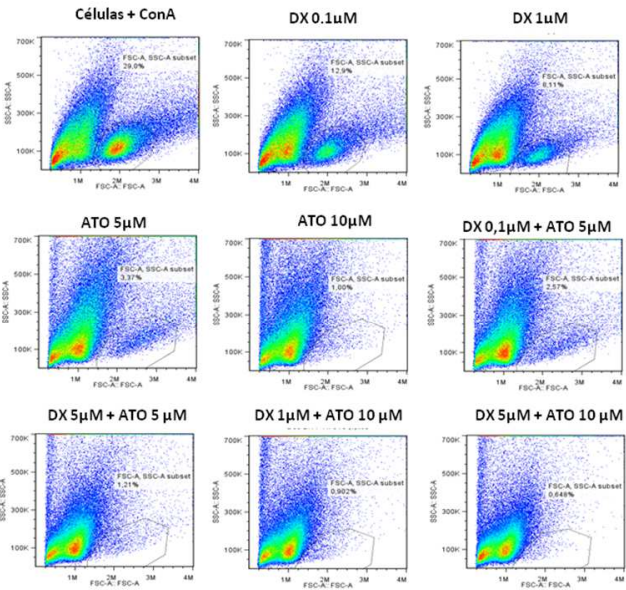

C.

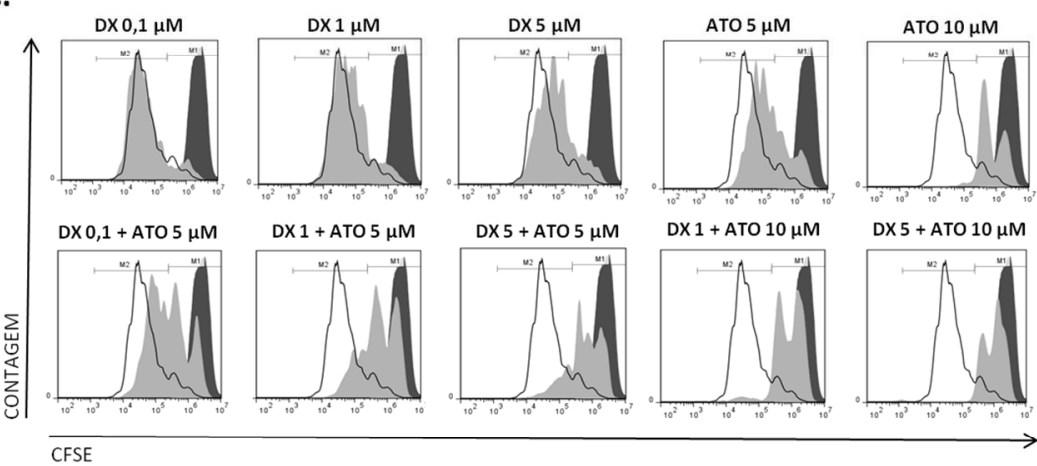

D.

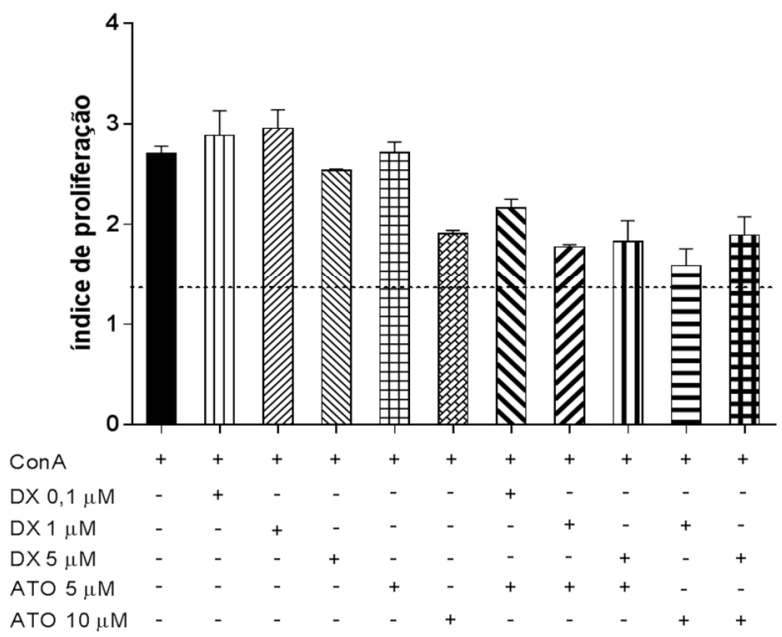

B.
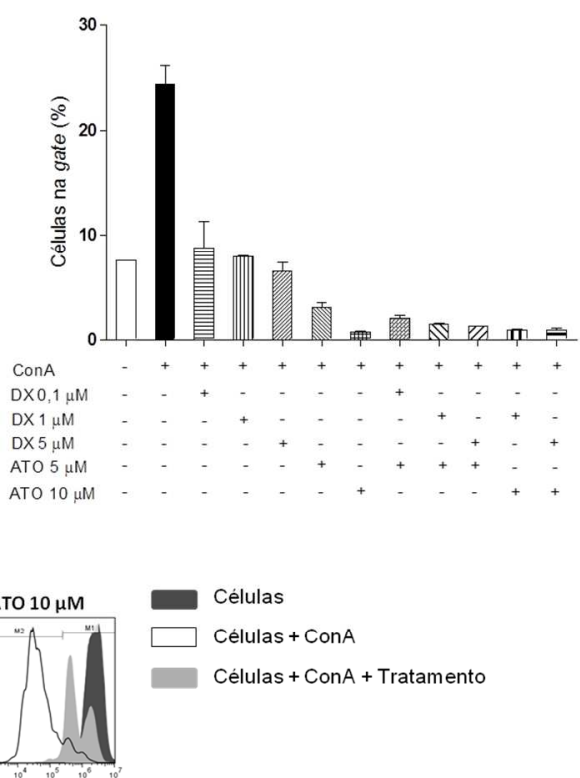

Figura 22. Efeito da ação simples ou combinada de dexametasona (DX) ou atorvastatina (ATO) sobre a população ( $A$ e B) e proliferação (C e D) de células de baço de camundongos C57BL/6 em cultura. Esplenócitos de camundongos naive foram marcados com carboxifluoresceína succinimidil éster (CFSE) e estimulados com concanavalina A (ConA). As células foram incubadas por 72 horas na presença de diferentes concentrações e combinações de DX e/ou ATO, utilizando-se placas de cultura de 96 poços, em triplicata. Posteriormente, as células foram levadas para leitura em citômetro de fluxo. A. Seleção de células com características linfocitárias. B. Representação gráfica do número de células identificadas no item A. C. Análise de proliferação de células. D. Índice de proliferação; a linha pontilhada representa o grupo de células que não foram submetidas à estimulação ou tratamentos. Estes dados são representativos de dois experimentos independentes. $\mathrm{n}=3$ animais por grupo. 


\subsection{Quantificação de citocinas no sobrenadante da cultura de esplenócitos tratados com dexametasona e atorvastatina}

Para saber se os tratamentos in vitro com DX e ATO conseguiram modular a produção de citocinas por esplenócitos no período de 72 horas de cultura, o sobrenadante foi coletado e submetido à dosagem das citocinas IL-6 e IL-10. Diferentemente do que foi observado nos experimentos in vivo pelos níveis de expressão de RNAm em camundongos expostos ao DSS, os resultados in vitro mostraram que os tratamentos exclusivos de DX ou ATO levaram à diminuição da síntese de IL-6 por esplenócitos estimulados com ConA de maneira dosedependente (Figura 23A). Ainda, essa supressão pareceu ser mais pronunciada com DX do que com ATO, uma vez que a concentração de $5 \mu \mathrm{M}$ de ATO pareceu não exercer grandes efeitos sobre a produção de IL-6. Ademais, os tratamentos concomitantes de DX e ATO diminuíram as concentrações de IL-6 de modo mais pronunciado do que com as drogas usadas isoladamente. Essa diminuição expressiva foi observada em todas as concentrações das drogas utilizadas em combinação, exceto para DX 0,1 $\mu \mathrm{M}+\mathrm{ATO} 5 \mu \mathrm{M}$.

Curiosamente, a terapia com DX não causou alteração significativa na síntese de IL10 por esplenócitos, enquanto que ATO elevou as concentrações da citocina, mas apenas na

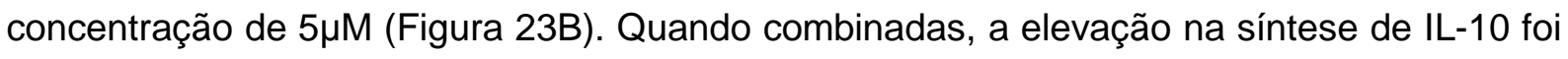
observada apenas quando a ATO $5 \mu \mathrm{M}$ estava presente e a produção de IL-10 foi decrescente quando aumentou-se a quantidade de DX no tratamento combinado. Entretanto, as diferentes associações das drogas envolvendo ATO 10 $\mathrm{MM}$ pareceram impedir a síntese de IL-10. 
A.

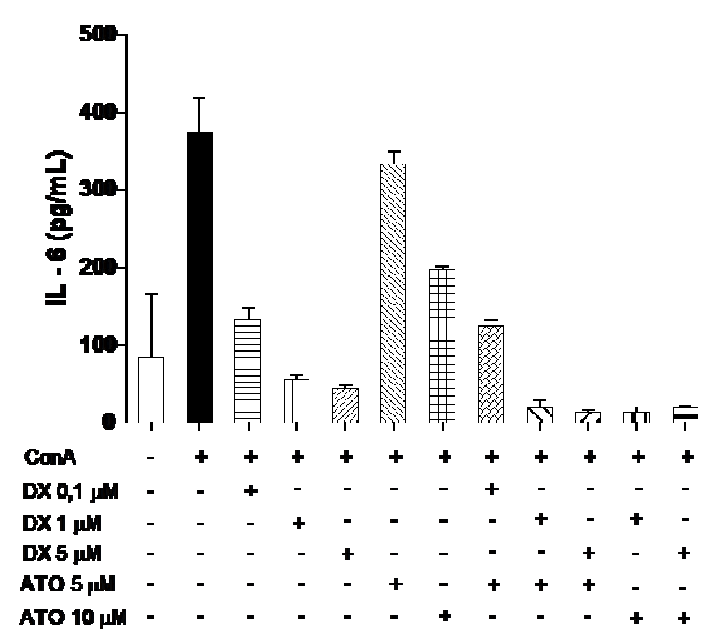

B.

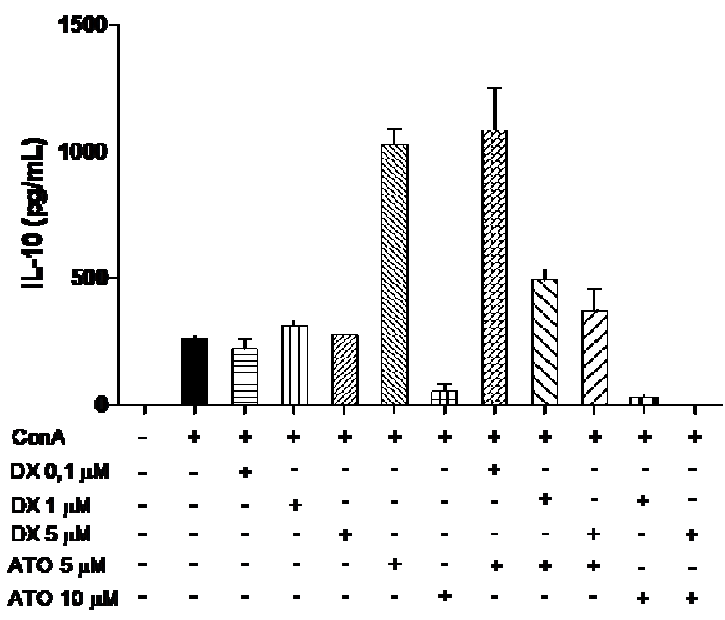

Figura 23. Dosagem de IL-6 (A) e IL-10 (B) por imunoensaio enzimático (ELISA - Enzyme Linked Sorbent Assay) do sobrenadante da cultura de esplenócitos tratados com dexametasona (DX) e/ou atorvastatina (ATO) in vitro. Esplenócitos de camundongos foram marcados com carboxifluoresceína succinimidil éster (CFSE) e estimulados com concanavalina A (ConA), utilizandose placas de cultura de 96 poços. As células foram incubadas por 72 horas com diferentes concentrações e combinações de DX e/ou ATO, em triplicata. Após, o sobrenadante da cultura foi coletado e direcionado para o ensaio de ELISA. Estes dados são representativos de um experimento. $\mathrm{n}=3$ animais por grupo.

\subsection{Avaliação de morte celular induzida pelo tratamento in vitro com dexametasona e atorvastatina}

Para verificar se as alterações na síntese das citocinas IL-6 e IL-10 por esplenócitos tratados in vitro foram resultado dos efeitos imunomoduladores e não da morte celular induzida pelas terapias, foram também realizados ensaios de identificação de morte celular por necrose e/ou apoptose.

As análises mostraram que aproximadamente $16 \%$ e $42 \%$ das células morreram espontaneamente (sem receber estímulo ou tratamentos) por necrose e apoptose, respectivamente (Figura 24 - barras cinza escuras e brancas). Além disso, considerando a morte celular por necrose, células que receberam apenas o estímulo (ConA) não diferiram daquelas não estimuladas no que se refere à quantidade de células mortas (Figura 24 - barras cinza escuro). Além do mais, como esperado, a adição de saponina no meio de cultura contendo apenas esplenócitos induziu praticamente 100\% das células à morte celular por necrose. Referindo-se aos diferentes tratamentos, foi observado que o uso isolado das drogas 
DX e ATO praticamente não causou a morte celular por necrose se comparados às células que não receberam estímulo ou tratamento. Já os tratamentos combinados pareceram aumentar a morte celular necrótica de maneira dependente das concentrações. Ainda assim, as análises mostraram apenas diferença estatística entre os grupos de células tratadas com

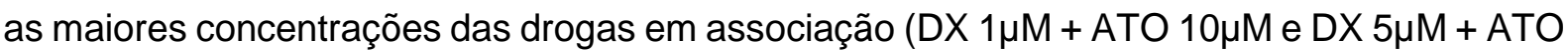
$10 \mu \mathrm{M})$ quando comparados ao grupo tratado com 0,1 $\mu \mathrm{M}$ (Figura 24 - barras cinza escuro).

Apesar dos esplenócitos que receberam apenas o estímulo não terem sido induzidos à morte por mecanismos de necrose, houve aumento de morte celular apoptótica quando comparados àqueles que não receberam estímulo ou tratamento (Figura 24 - barras brancas). Confrontando esses achados com os resultados obtidos dos grupos de células tratadas com as diferentes drogas, não houve morte decorrente da via de apoptose, uma vez que o aparente aumento do número de mortes observado com os tratamentos individuais foi causado provavelmente pelo estímulo e não necessariamente pela ação de DX e/ou ATO. Essa observação pôde ser confirmada após a avaliação da frequência de células vivas (Figura 24 - barras cinza-claro), cujos os números foram semelhantes entre os grupos de células tratadas individualmente e àquelas que receberam apenas o estímulo. Considerando as células tratadas em combinação, estas pareceram ter uma quantidade pouco menor de células vivas quando comparadas com as células apenas estimuladas ou tratadas com as drogas individualmente. Tratamentos com as concentrações DX 0,1 $\mu \mathrm{M}+\mathrm{ATO} 5 \mu \mathrm{M}, \mathrm{DX} 5 \mu \mathrm{M}+\mathrm{ATO}$ $5 \mu \mathrm{M}$ e DX $5 \mu \mathrm{M}+\mathrm{ATO} 10 \mu \mathrm{M}$ foram estatisticamente diferentes do grupo de células que não foram estimuladas ou tratadas (Figura 24 - barras cinza-claro). Entretanto, o número de células mortas foi relativamente homogêneo entre os grupos de células tratadas com a associação das drogas com diferentes concentrações.

Assim, conclui-se que os tratamentos individuais com DX e ATO não causaram a morte celular de esplenócitos e que as terapias combinadas pareceram aumentar a morte celular por necrose em detrimento à apoptose, independentemente das concentrações das drogas. Ainda, a associação de drogas pareceu causar mais mortes de esplenócitos (independentemente da via) quando comparados aos tratamentos individuais ou com as 
células apenas estimuladas. Apesar disso, o número de células mortas foi relativamente homogêneo dentro dos diferentes grupos tratados isoladamente ou em associação e, desse modo, parece não ser suficiente para explicar as alterações observadas nas concentrações das citocinas IL-6 e IL-10 sintetizadas após estimulação in vitro. Sendo assim, pode-se assumir que DX e ATO modulam o comportamento das células do sistema imune, sem necessariamente induzir à morte celular.

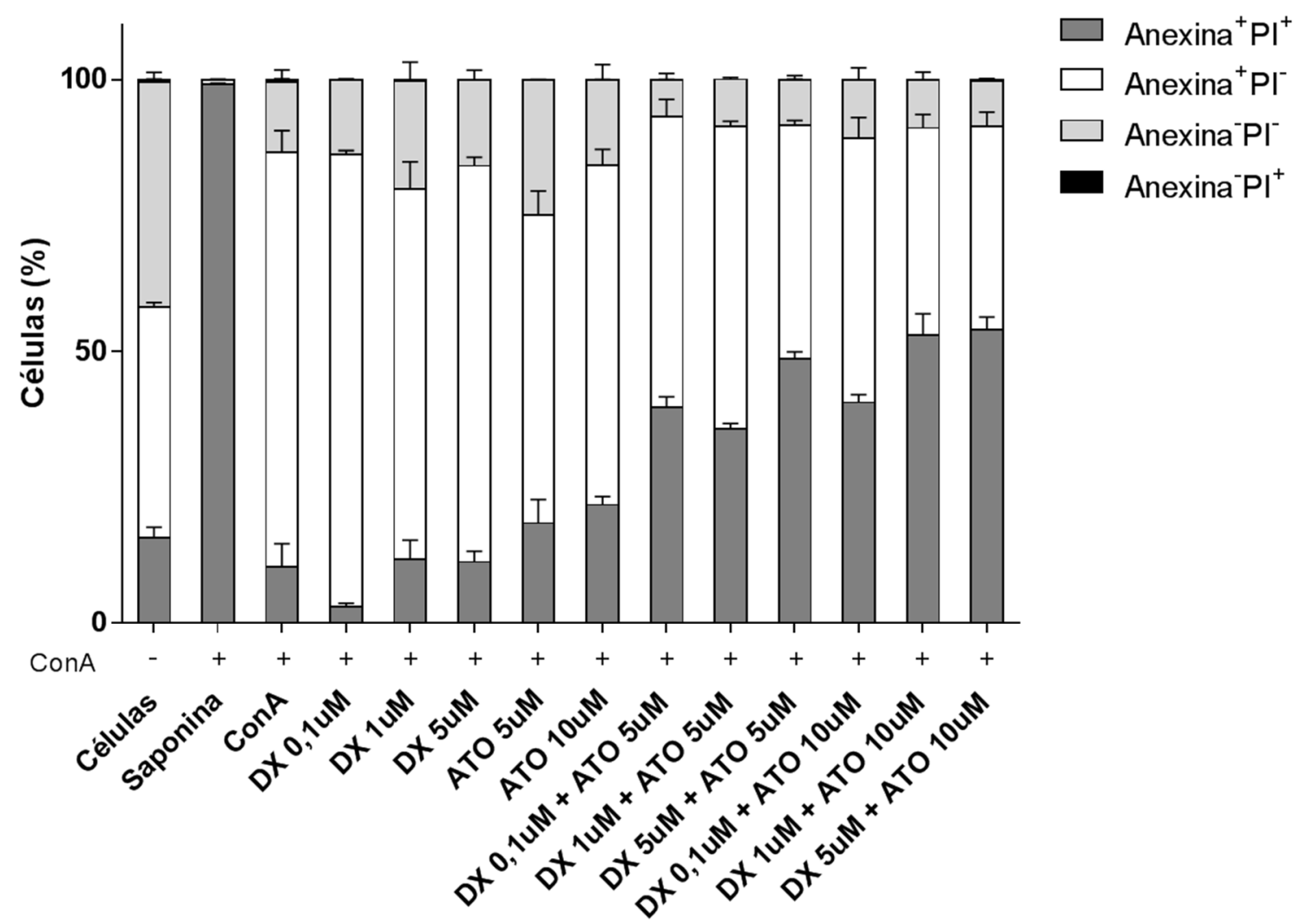

Figura 24. Avaliação de morte celular induzida pelos tratamentos in vitro com dexametasona (DX) e/ou atorvastatina (ATO). Esplenócitos de camundongos foram estimulados com concanavalina A (ConA) e incubados por 72 horas com diferentes concentrações e combinações de DX e/ou ATO, utilizando-se placas de cultura de 96 poços, em triplicata. Após, as células foram marcadas com anexina e iodeto de propídio (PI) e rapidamente levadas para leitura em citômetro de fluxo. Barras pretas. Frequência de células (\%) mortas por mecanismos de necrose. Barras brancas. Frequência de células (\%) mortas por mecanismos de apoptose. Barras cinza-claro. Frequência de células (\%) vivas. Barras cinza-escuro. Não possuem significado fisiológico. Saponina 0,01\% foi utilizada como controle positivo de morte celular necrótica. Estes dados são representativos de um experimento. $n=3$ animais por grupo. " $\mathrm{p}<0,05$ comparado ao grupo " $\mathrm{DX} 0,1 \mu \mathrm{M}$ " dentro das marcações Anexina+ $\mathrm{PI}^{+}$; \# $\mathrm{p}<0,05$ comparado ao grupo "DX $0,1 \mu \mathrm{M}$ " dentro das marcações Anexina+PI; ${ }^{\&} \mathrm{p}<0,05$ comparado ao grupo "Células" dentro das marcações Anexina-PI. 


\subsection{Cultura ex vivo de esplenócitos de camundongos tratados com dexametasona e atorvastatina}

De modo a também caracterizar o comportamento das células frente à ação de DX e ATO, esplenócitos de camundongos expostos à água contendo DSS e tratados com as diferentes combinações de drogas foram obtidos, reestimulados in vitro e deixados por 72 horas em cultura. Posteriormente as células foram analisadas quanto à proliferação e síntese de IL-10.

As análises mostraram que as células com características de linfócitos, independentemente dos tratamentos prévios, replicaram-se de forma muito semelhante (Figuras 25A e B). No entanto, células provenientes de animais expostos ao DSS que não receberam tratamento específico apresentaram baixa capacidade de sintetizar a citocina antiinflamatória IL-10 após reestimulação in vitro. Diferentemente do que foi observado no experimento in vitro, a terapia isolada com DX pareceu recuperar a capacidade das células de animais doentes de produzirem IL-10, alcançando concentrações semelhantes às observadas em células do grupo controle saudável (Figura 25C). Os tratamentos contendo ATO pareceram não influenciar significativamente a síntese de IL-10 neste contexto.

De modo interessante, apesar do tratamento com DX ter aumentado a síntese de IL10 por esplenócitos, isso não foi suficiente para suprimir a proliferação celular, sugerindo que as células de baço de animais expostos ao DSS podem estar menos susceptíveis aos mecanismos reguladores dependentes de IL-10. 
A.

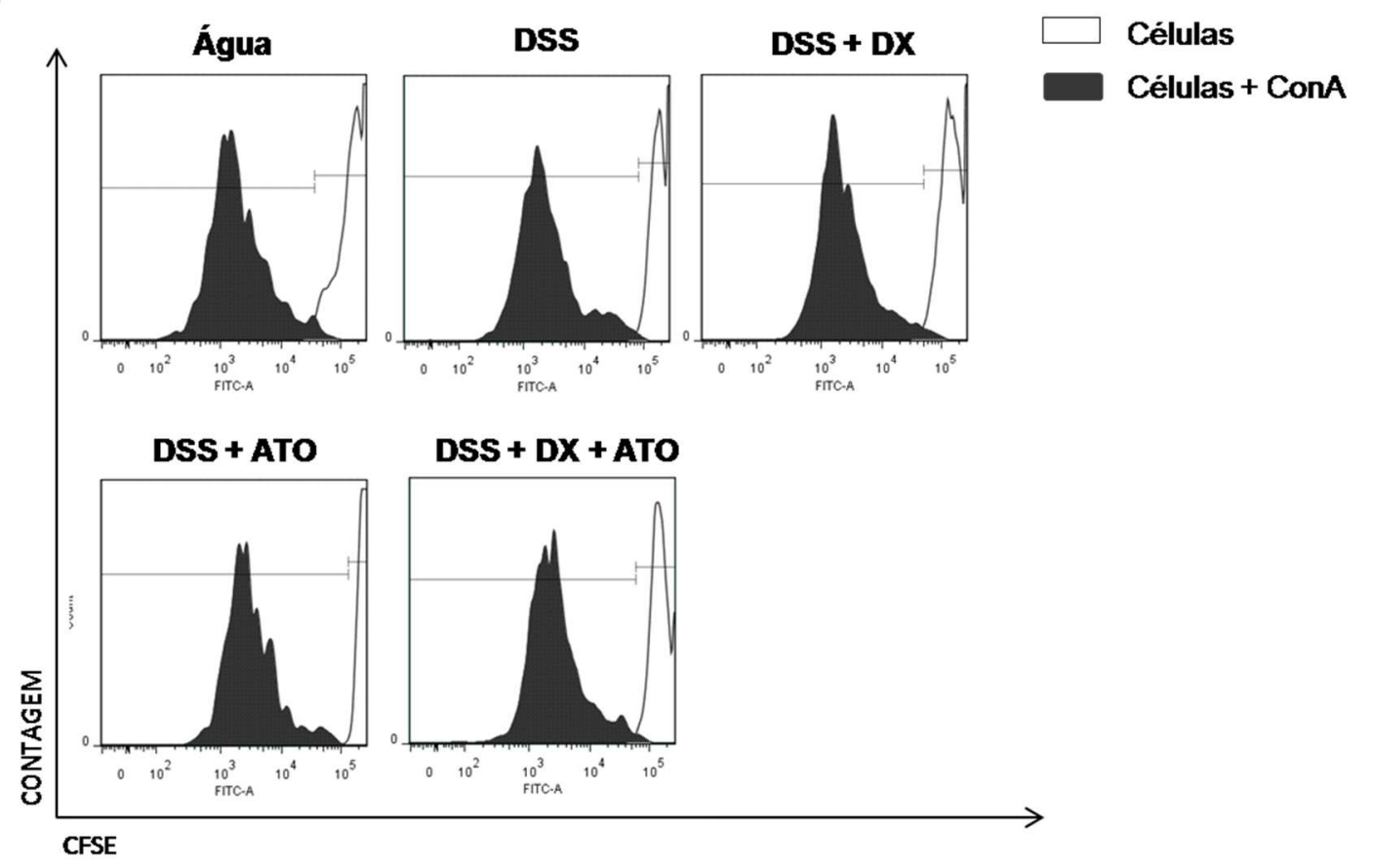

B.

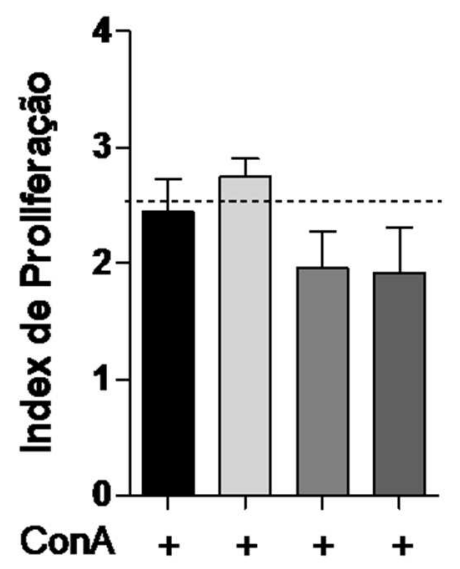

C.

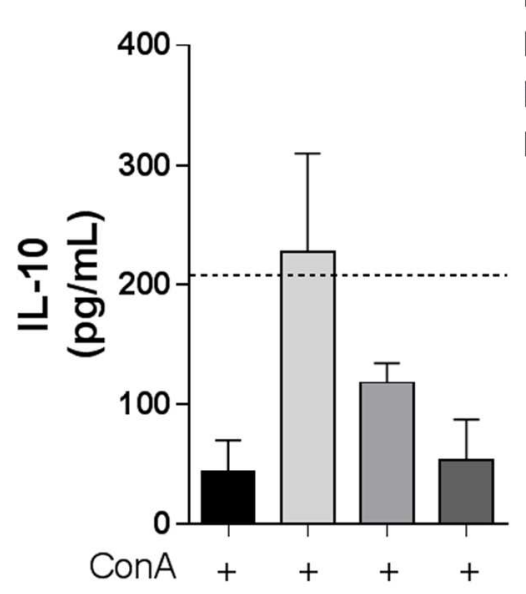

DSS

DSS + DX

DSS + ATO

$D S S+D X+A T O$

Figura 25. Cultura ex vivo de células de baço de camundongos submetidos à colite experimental, tratados com o veículo (salina), dexametasona (DX) ou atorvastatina (ATO), isoladamente ou em associação. Os camundongos foram expostos por 6 dias à água contendo dextran sulfato de sódio (DSS) $3 \%$ e foram tratados com doses diárias de DX $1 \mathrm{mg} / \mathrm{kg}$, ATO $10 \mathrm{mg} / \mathrm{kg}$ ou com a associação das drogas, entre os dias 3-5, contados a partir do início da indução da colite. No $6^{\circ}$ dia, os esplenócitos foram colhidos, marcados com carboxifluoresceína succinimidil éster (CFSE) e reestimulados com concanavalina A (ConA) por 72 horas, para posterior leitura em citômetro de fluxo para análise de proliferação. O sobrenadante foi direcionado para a quantificação da citocina IL-10. A. Histogramas de proliferação celular. B. Índice de proliferação. C. Quantificação de IL-10 por imunoensaio enzimático (ELISA). Os resultados foram expressos em $\mathrm{pg} / \mathrm{mL}$. Estes dados são representativos de um experimento. $n=3$ animais por grupo. ${ }^{*} \mathrm{p}<0,05$. 


\subsection{Estudo da suscetibilidade de esplenócitos de camundongos tratados com dexametasona e atorvastatina à supressão por células $\mathrm{CD}^{+}{ }^{+} \mathrm{FoxP} 3^{+}$}

Como houve aumento relativo na síntese de IL-10 após uso de DX, mas nenhuma alteração na proliferação celular, procurou-se avaliar como estava a responsividade das células do baço de animais doentes frente à sinais reguladores. Para isso, células do baço de camundongos previamente tratados com DX e/ou ATO foram co-cultivadas com células $\mathrm{CD}^{+}{ }^{+} \mathrm{FoxP}^{+}$(supostamente reguladoras) de camundongos sadios na proporção de 10:1 ou $1: 5$, respectivamente, por 72 horas.

Os resultados mostraram que as células de animais tratados em associação com ATO e DX pareceram ser menos susceptíveis, embora não significativo, à regulação por células Treg na proporção de 1:10 (Figura 26A). Ainda, como esperado, os esplenócitos dos animais tratados ou controles foram mais susceptíveis à regulação quando a quantidade de células Treg foi maior (Figura 26B). Entretanto, nenhuma alteração foi observada com as células provenientes de camundongos que receberam outros tipos de tratamentos, independentemente da proporção de células (Figuras 26A e B). 
A.

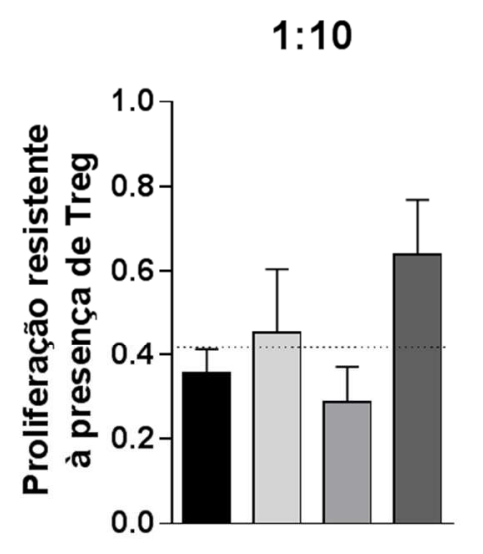

B.

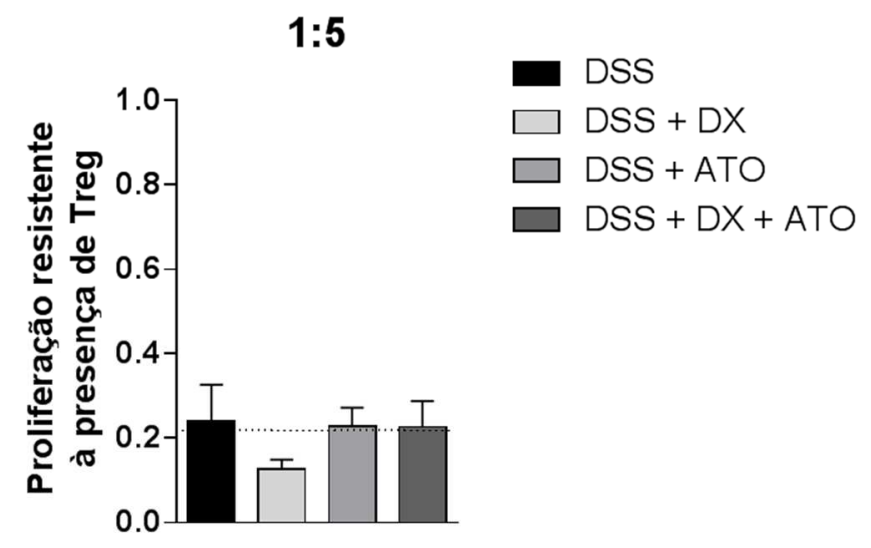

C.

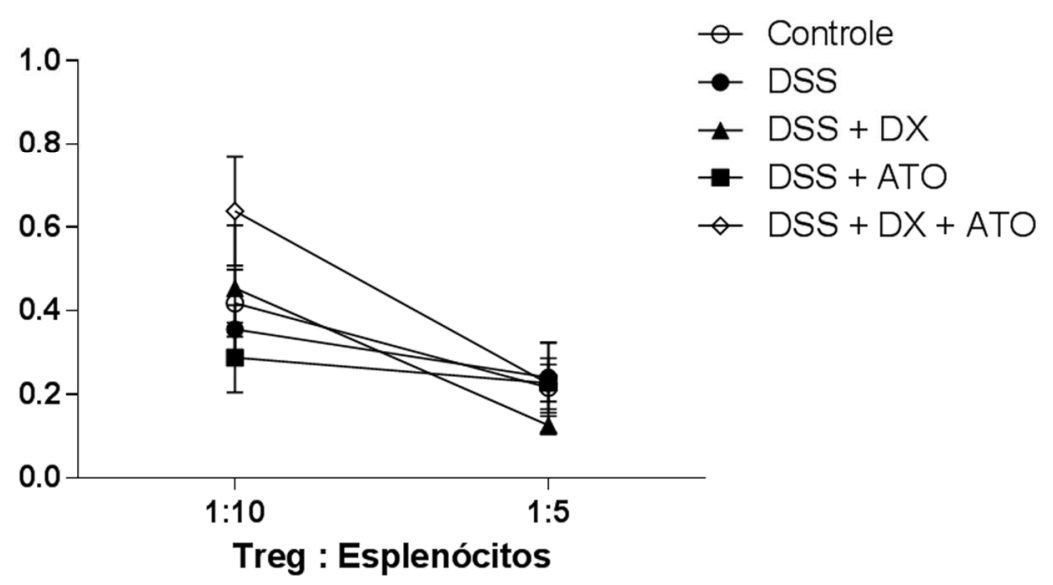

Figura 26. Co-cultura de células $\mathrm{CD}^{+}{ }^{+} \mathrm{FoxP}^{+}$provenientes de camundongos saudáveis com células de baço de camundongos submetidos à colite experimental, tratados com o veículo (salina), dexametasona (DX) ou atorvastatina (ATO), isoladamente ou em associação. No 6o dia de experimento, as células do baço foram extraídas, adicionadas às placas de cultura de 96 poços juntamente com células $C D 4^{+} \mathrm{FoxP} 3^{+}$na proporção de 10 para 1 ou 5 para 1 e estimuladas com $3 \mu \mathrm{g} / \mathrm{mL}$ de concanavalina $\mathrm{A}$ (ConA). As células foram incubadas por 72 horas e 16 horas antes do término foi adicionado bromodeoxiuridina (BrdU) às culturas. Após, a proliferação celular foi determinada por ELISA através da detecção de BrdU incorporado pelas células em replicação. Estes dados são representativos de um experimento. $n=3$ animais por grupo. 
Discussão/115

$5 \cdot$ DISCUSSÃO 


\section{DISCUSSÃO}

Os tratamentos correntes da DII são focados, principalmente, no controle das respostas imunes exacerbadas. Com este propósito, são utilizados fármacos com conhecidas propriedades imunossupressoras, tais como os GCs. Paralelamente, novos estudos têm apontado para o importante papel das estatinas na modulação das respostas imunológicas. As estatinas, além de apresentarem baixa toxicidade em relação aos demais fármacos, ainda são, juntamente com os GCs, notavelmente mais acessíveis que outras drogas usualmente empregadas na terapia da UC e/ou CD. Uma vez que estudos retrospectivos mostraram que a combinação de GCs e estatinas geraram resultados promissores no tratamento da DII (CROCKETT et al., 2012), o objetivo desse projeto foi avaliar os efeitos dessa associação na imunomodulação de camundongos submetidos à inflamação intestinal induzida experimentalmente.

Para aprimorar nossos estudos, inicialmente preocupou-se com o modelo experimental a ser utilizado. De maneira geral, os modelos in vivo são classificados por espontâneos, microbianos, químicos e imunológicos (SALEH; ELSON, 2011) e são utilizados de acordo com os objetivos propostos em cada estudo (KIESLER; FUSS; STROBER, 2015). O dextran sulfato de sódio (DSS) é um polissacarídeo polissulfatado sintético, categorizado como indutor químico da colite experimental. Seu mecanismo de ação não está totalmente elucidado, mas sabe-se que ele causa a ruptura da integridade da barreira epitelial intestinal, provavelmente por se ligar a ácidos graxos de cadeia média presentes no cólon, resultando na formação de vesículas nanométricas que podem se fundir com as membranas das células colônicas e, assim, ativar vias de sinalização inflamatórias (LAROUI et al., 2012). Esta forma de indução de inflamação intestinal experimental possui algumas vantagens sobre os outros métodos disponíveis: além de sua fácil utilização, estudos têm validado o modelo de DSS como método experimental altamente relevante para estudos translacionais, incluindo novas formas de tratamento da DII (MELGAR et al., 2008). Ainda, o DSS promove uma inflamação intestinal mais extensa e homogênea que outros modelos experimentais, facilitando a coleta 
e o direcionamento de amostras para diversas análises, além de causar respostas imunológicas similares às DII nos humanos (PERSE; CERAR, 2012). Desse modo, o modelo de DII experimental por exposição à água contendo DSS foi escolhido para os estudos de associação de GCs e estatinas, uma vez que ele foi o que mais se adequou aos principais objetivos propostos neste estudo.

Outra precaução praticada foi escolher as melhores doses e/ou via de administração das drogas de tratamento. Para a ATO, as doses escolhidas para o estudo "dose x resposta" foram baseadas em outros trabalhos que utilizaram esta estatina como fármaco de tratamento (AKTUNC et al., 2011; YOUSSEF et al., 2002). Como discutido anteriormente, optou-se por não avaliar diferentes concentrações de DX, uma vez que diversos estudos já utilizam a droga em doses diárias de $1 \mathrm{mg} / \mathrm{kg}$ em diferentes modelos experimentais de DII (BAGHAEI et al., 2010; BENTO et al., 2008; FAKHRAEl et al., 2014; REUTER et al., 2012; WU et al., 2012), além de permitir a comparação com os estudos em andamento do nosso grupo de pesquisa. Ademais, existiu a preocupação sobre as possíveis vias de administração a serem utilizadas para os tratamentos farmacológicos com DX e ATO. Estudos de associação de drogas, bem como estudos de eficácia para novos compostos farmacológicos, usam preferencialmente a v.o. para tratamentos clínicos devido à simplicidade da administração, além de ser um método seguro, não invasivo e economicamente vantajoso (GUPTA; BHANDARI; SHARMA, 2009). Ainda, as estatinas estão disponíveis na clínica exclusivamente sob a forma farmacêutica de comprimido. Entretanto, como o modelo experimental de DII escolhido para o estudo consistiu no uso de DSS 3\% diluído na água de beber dos camundongos, existiu a preocupação de que a ruptura na integridade física do epitélio intestinal causada pelo polissacarídeo pudesse comprometer a farmacocinética das drogas escolhidas para o tratamento. Porém, os resultados mostraram que a v.o. não apenas pôde ser utilizada em nosso modelo experimental, como pareceu ser a escolha mais eficaz para o uso de ATO no que se refere à diminuição do escore clínico e aumento da sobrevida dos animais. Ainda, a dose diária de ATO $10 \mathrm{mg} / \mathrm{kg}$ foi a que gerou maiores benefícios para os camundongos enfermos, aumentando a sobrevida e diminuindo os sinais clínicos durante os períodos agudos e 
crônicos da inflamação intestinal. Considerando-se o uso diário de DX na dose de $1 \mathrm{mg} / \mathrm{kg}$, a terapia causou perda de peso acentuada, não alterou o curso da doença e ainda antecipou a morte dos animais doentes, independentemente da via de administração. Apesar desses achados, nós prosseguimos com os estudos de associação de modo a verificar se as estatinas poderiam recuperar os efeitos do esteroide e modificar o curso da colite, especialmente em tratamentos em curto prazo.

Os resultados do estudo de sobrevivência com a associação dos fármacos pareceram sustentar a hipótese de que as estatinas são drogas promissoras para o tratamento das DII. Como já observado anteriormente, os camundongos tratados continuamente com ATO sobreviveram mais aos graves danos causados pela inflamação crônica intestinal do que aqueles que receberam os outros esquemas terapêuticos, confirmando dados da literatura que mostraram aumento na sobrevida de animais tratados com ATO na colite experimental induzida pelo ácido 2,4,6-trinitrobenzenosulfônico (TNBS) (AKTUNC et al., 2011). Entretanto, no nosso estudo as terapias contínuas com DX isolada ou associada à ATO pareceram diminuir o peso corporal e antecipar a mortalidade dos camundongos doentes. Apesar dos GCs serem o tratamento de escolha para os pacientes com DII em situações específicas (MOWAT et al., 2011), essa piora observada dos animais doentes tratados em longo prazo com DX corrobora os achados de outros trabalhos de nosso grupo de pesquisa (dados não publicados). Além disso, Kojouharoff e colaboradores também observaram que o tratamento de animais submetidos à colite experimental por DSS 5\% com altas doses de DX $(3 \mathrm{mg} / \mathrm{kg})$ causou a piora no escore clínico da doença (KOJOUHAROFF et al., 1997). Outro estudo também mostrou que o pré-tratamento com $\mathrm{DX}(0,06 \mathrm{mg} / \mathrm{dia})$ de animais induzidos à colite por DSS $10 \%$ agravou os parâmetros clínicos da enfermidade (VAN MEETEREN; MEIJSSEN; ZIJLSTRA, 2000). Algumas hipóteses que poderiam explicar essas complicações decorrentes do uso de esteroides giram em torno da alta capacidade imunossupressora desses fármacos, já que a resposta imunológica é necessária para combater a translocação microbiana na doença, porém de forma regulada. GCs são conhecidos por induzirem linfócitos T, células NK e monócitos à apoptose, além de diminuírem a síntese de citocinas pró-inflamatórias por 
diversas células do sistema imune (BRATTSAND; LINDEN, 1996; MIGLIORATI et al., 1994; SCHMIDT et al., 1999; TUCKERMANN et al., 2005). Dentro desse contexto, somada à disfunção da barreira epitelial característica da doença, o organismo não conseguiria combater a translocação bacteriana do lúmen intestinal para os tecidos e corrente circulatória, podendo gerar complicações como abscessos, endocardite e até sepse (SARTOR, 2008). Além disso, o uso de GCs na clínica também não é totalmente efetivo, já que um alto número de pacientes é resistente ao tratamento ou torna-se dependente em consequência da falência adrenal induzida pela terapia prolongada (MOWAT et al., 2011; MUNKHOLM et al., 1994). Ainda, o uso contínuo de esteroides não é extensivamente recomendado devido aos importantes efeitos adversos encontrados (atrofia cutânea, osteoporose, glaucoma, síndrome de Cushing, diabetes mellitus, retardo no crescimento, hipogonadismo, hipertensão, trombose, imunossupressão, entre outros de gravidades variáveis) (MAHADEVAN, 2004; SCHACKE et al., 2002). GCs são conhecidos por inibir o transporte de aminoácidos, diminuir a função de ribossomos durante a síntese proteica e por aumentar a proteólise em células musculares, contribuindo para a perda de peso, tal como foi observado em camundongos tratados com o esteroide (ELLIOTT; PETERS; WHITE, 1971; HASSELGREN, 1999; KOSTYO; REDMOND, 1966). A adição da estatina ao tratamento da DII com GC pareceu não promover melhora na longevidade dos camundongos quando comparada ao tratamento simples com o esteroide, provavelmente por contribuir com a imunossupressão dos animais doentes, já que as estatinas também podem causar a apoptose de células do sistema imune e exercer outros efeitos imunorreguladores (BRINKKOETTER et al., 2006; VAMVAKOPOULOS; GREEN, 2003; WANG et al., 2008).

Após observar a piora relativa com uso dos tratamentos contendo DX em detrimento da melhora com o uso de ATO isolada, procurou-se avaliar quais as alterações imunológicas iniciais causadas pelas diferentes terapias que modificariam o curso da doença em longo prazo. Assim, após 3 doses dos respectivos tratamentos, foi observado que, além do uso isolado de ATO, a combinação de DX e ATO também pareceu melhorar os aspectos clínicos e histológicos dos animais expostos ao DSS. Entretanto, o uso isolado de ATO continuou 
mostrando-se mais efetivo que os outros esquemas terapêuticos, melhorando significativamente tanto o escore clínico como as avaliações macro e microscópicas do intestino grosso dos camundongos, corroborando outros estudos que também observaram que o uso não apenas de ATO, mas também de outras estatinas (sinvastatina, pravastatina), atenuou os sinais clínicos da colite experimental (ABE et al., 2012; AKTUNC et al., 2011; KANAGARAJAN et al., 2008; LEE, J. Y. et al., 2007; SASAKI et al., 2003). Além da capacidade imunomoduladora das estatinas já descritas anteriormente, estudos também atentam para o papel imunossupressor dessas drogas, que podem contribuir para a hipocelularidade encontrada nas análises histológicas e a diminuição do processo inflamatório. Após transplante cardíaco, pacientes sob uso de estatinas tiveram diminuição da rejeição ao órgão, dos distúrbios hemodinâmicos e aumento da taxa de sobrevivência (KOBASHIGAWA et al., 1995; WENKE et al., 1997).

Considerando o tratamento em curto prazo com DX isolada, este não exerceu efeitos clinicamente relevantes, além de ter causado a perda de peso dos animais medicados, semelhantemente ao que foi observado em um estudo em que se usou budesonida (um outro GC) para tratar camundongos expostos a água contendo DSS 4\% por 7 dias (SANN et al., 2013). Além disso, os parâmetros clínicos avaliados neste trabalho supracitado (escore clínico, análise histológica e concentração de proteína amiloide A sérica - uma proteína de fase aguda) foram piores quando comparados aos animais doentes sem tratamento.

De modo interessante, a associação de DX e ATO apresentou uma eficácia dicotômica: enquanto o escore clínico da doença foi reduzido e as análises histológicas mostraram melhora significativa do cólon intestinal, como discutido anteriormente, os animais apresentaram perda de peso e nenhuma melhora macroscópica do conteúdo intestinal. Entretanto, durante os experimentos, foi observado que o conteúdo fecal da maioria dos camundongos doentes tratados com associação de drogas apresentou coloração bastante escura quando comparado ao conteúdo fecal dos animais que receberam outros tratamentos (dados não mostrados). Este fato parece ser importante, porque relatos na literatura demonstram que fezes escuras possuem alta probabilidade de possuírem sangue proveniente 
de lesões no trato gastrointestinal superior (ZUCKERMAN et al., 1995). Estudos mostram que ratos e camundongos expostos a água contendo DSS $5 \%$ possuem inflamação e sangramento no intestino delgado, além de lesões no estômago, já à partir do terceiro dia de exposição ao DSS (ELSHEIKH et al., 2012). Ainda, o uso de esteroides parece estar associado com o surgimento de hemorragias e perfurações no trato gastrointestinal superior dos usuários e o uso concomitante de duas ou mais drogas anti-inflamatórias aumenta significativamente o risco deste tipo de complicação (HERNANDEZ-DIAZ; RODRIGUEZ, 2001; NARUM; WESTERGREN; KLEMP, 2014). Neste contexto, as discrepâncias encontradas nas análises macroscópicas (escore pós morte) e sinais clínicos/ histologia dos camundongos tratados com a associação de DX e ATO poderia ser parcialmente explicada, uma vez que o sangue encontrado nas fezes desses animais pode ter sido originado de outros locais do trato gastrointestinal que não o cólon. Entretanto, outros estudos são necessários para confirmar esta hipótese.

Ademais, os efeitos positivos observados com o tratamento conjunto não foram maiores que o uso isolado de ATO, inferindo que, neste contexto, a terapia com GCs poderia ser dispensada clinicamente. Entretanto, mantivemos o grupo tratado com a associação de drogas nos estudos posteriores de modo a verificar quais as alterações imunológicas causadas por essa terapia e no que ela difere do tratamento com ATO isolada que a torna relativamente menos efetiva. Além disso, esse tipo de avaliação possui grande relevância clínica, uma vez que diversos pacientes utilizam estatinas para combater e/ou prevenir doenças cardiovasculares e, eventualmente, acabam fazendo uso conjunto com GCs para tratar de outras enfermidades de origem inflamatória.

As avaliações imunológicas após 3 doses dos respectivos tratamentos mostraram que a conjunção de ATO e DX reduziu acentuadamente o número de leucócitos totais no sangue, baço e LNM, diferentemente dos tratamentos individuais que reduziram essas células apenas na circulação. A contagem diferencial de sangue periférico indicou que os principais alvos de ação dos fármacos associados foram os linfócitos e monócitos, que estão diminuídos. O uso de DX isolada levou a alterações semelhantes às causadas pelo uso das drogas associadas, 
porém menos pronunciadas. De modo interessante, o uso de ATO reduziu apenas o número de monócitos circulantes. Mesmo que análises do número total das subpopulações leucocitárias circulantes devam ser cautelosas, uma vez que os intervalos de valores de referência para uso clínico são relativamente grandes, as diferenças encontradas não podem ser ignoradas. De fato, como abordado previamente, o uso de GCs e estatinas pode causar a morte de linfócitos $\mathrm{T}$ e de monócitos, alterando o número de células circulantes (BRINKKOETTER et al., 2006; SCHMIDT et al., 1999; TUCKERMANN et al., 2005; VAMVAKOPOULOS; GREEN, 2003). Entretanto, não apenas a morte, mas a alteração no comportamento ou função dessas células, influenciado pelos tratamentos, também sugere hipóteses para explicar os resultados obtidos. O uso de estatinas altera a expressão de moléculas de sinalização preniladas localizadas na superfície das células do sistema imune, prejudicando a comunicação celular e consequente migração pelos diferentes órgãos. Considerando os monócitos, pacientes com CD possuem elevado número destas células na circulação que migram para o intestino devido ao aumento da síntese da molécula quimiotáxica de monócitos MCP-1, produzidas principalmente por monócitos/macrófagos, células endoteliais e IEC no local da inflamação (REINECKER et al., 1995). ATO foi descrita como sendo importante inibidor da produção de MCP-1, observada em estudos ex vivo com monócitos de pacientes com CD, alterando, assim, o deslocamento dessas células até o cólon (GRIP et al., 2004). Esses resultados podem explicar a frequência aumentada de macrófagos/monócitos no baço e reduzida na mucosa intestinal, como observado na análise da frequência de células $C D 11 b^{+}$, após os tratamentos contendo ATO.

Os camundongos doentes tratados com ATO associada à DX apresentaram frequência diminuída de ambas as populações de DCs no baço, mas elevada frequência de DCs CD11 ${ }^{+} C D 11 b-$ na LP. Já o tratamento isolado com ATO reduziu a frequência de DCs no baço, mas aumentou significativamente DCs CD11 ${ }^{+}$CD11 b nos LNM. O uso de DX isolada não induziu nenhuma alteração relevante nessas populações. DCs possuem diversas subpopulações que, além de exercerem funções diferentes, também estão localizadas em regiões preferenciais do organismo (FINK; FROKIAER, 2008). DCs pertencentes ao tecido 
linfoide associado ao intestino (GALT - gut-associated lymphoid tissue), que incluem principalmente a LP, LNM, PP e folículos linfoides isolados, geralmente exibem um fenótipo imaturo, em situações de homeostase. Além disso, estas células possuem expressão aumentada do receptor de quimiocina CCR7, que permite a migração entre esses diferentes locais (JANG et al., 2006). Ainda, estudos mostram que DCs CD11 b+CD11c $\mathrm{c}^{+}$possuem origem mieloide e são responsáveis por projetar seus dendritos para o lúmen intestinal, por dentre as junções das IEC, para identificar possíveis patógenos microbianos (MERAD et al., 2013). Já DCs CD11b-CD11 $\mathrm{c}^{+}$possuem origem linfoide e promovem preferencialmente a resposta de células T CD8+ (TURLEY; FLETCHER; ELPEK, 2010), corroborando os resultados observados neste estudo após a utilização de ATO isolada ou em associação com DX, que causou aumento da frequência de células $\mathrm{CD}^{+}$no baço e LNM. Entretanto, existem relatos na literatura demonstrando que as estatinas diminuem a capacidade endocítica de DCs, a produção basal de citocinas pró-inflamatórias e a habilidade de induzir a proliferação de células T (YILMAZ et al., 2006). Assim, torna-se necessária a avaliação funcional mais aprofundada dessas subpopulações de DCs, de modo a compreender se o aumento da frequência dessas células na LP e/ou LNM com os diferentes tratamentos envolvendo ATO está realmente relacionado com a alteração de função de células T citotóxicas nos LNM e baço.

De modo interessante, apenas o tratamento com ATO isolada aumentou a frequência de células NK no baço dos camundongos doentes. Entretanto, assim como para as DCs, trabalhos têm apontado um papel das estatinas na diminuição das funções citotóxicas dessas células (CROSBIE et al., 2013), como consequência da diminuição da prenilação de proteínas importantes para as funções efetoras. Entre elas está a molécula de adesão LFA-1, que é determinante para a conjugação células NK-célula alvo e para a polarização dos grânulos citotóxicos (BRYCESON et al., 2005; RAEMER; KOHL; WATZL, 2009; TANAKA et al., 2007). Entretanto as vias de sinalização para a ativação das células NK parecem ser preservadas após o uso das drogas (RAEMER et al., 2009). Desse modo, apesar do aumento da frequência 
dessa população no baço, ainda torna-se necessário investigar o estado de ativação dessas células dentro do contexto imunológico induzido pelo tratamento isolado com ATO.

Considerando a expressão de RNAm para síntese de moléculas inflamatórias no cólon, os animais doentes tratados com salina aumentaram a expressão de mediadores inflamatórios, concordando com trabalhos da literatura onde foi observado que após 5 dias de consumo de água contendo DSS 3,5\% ocorre aumento significativo de IL-1 $\beta$, IFN- $\gamma$, TNF, IL6, IL-12 e IL-10 no cólon dos camundongos (YAN et al., 2009). Comparando-se os tratamentos, ATO isolada ou associada a DX apresentaram efeitos distintos entre si. A terapia combinada foi capaz de reduzir a expressão de RNAm de IL-1 $\beta$, IL-17A e IFN-ү, do mesmo modo que o tratamento com DX isolada (exceto para IFN-y), porém esta redução foi menos pronunciada. Estes resultados corroboram parcialmente os estudos de Nishiyori e colaboradores, que observaram a supressão de IL-1ß, IL-17, TNF e IFN- $\gamma$ após o tratamento com DX em modelo experimental de colite induzida por piroxicam (NISHIYORI; NAGAKURA; ICHIKAWA, 2009). IL-1 $\beta$ possui importante papel na DII e é primariamente produzida por monócitos/macrófagos durante a inflamação, exercendo diversos efeitos, tais com o recrutamento de outros tipos de leucócitos (monócitos, neutrófilos) para o sítio inflamado, além de estar também relacionada com aumento dos danos teciduais durante as reações inflamatórias da doença (DIONNE et al., 1998; RUGTVEIT et al., 1994). IFN-y e IL-17A são as principais citocinas produzidas por linfócitos Th1 e Th17, respectivamente, e possuem papel fundamental na patogênese da DII, como já discutido inicialmente (ITO et al., 2008; NEURATH et al., 1995; VERDIER et al., 2012). Conjuntamente, esses resultados corroboram a melhora histológica relativa e diminuição da celularidade nos camundongos tratados com DX isolada ou em associação com ATO, provavelmente por diminuir as reações inflamatórias locais.

ATO isolada não foi capaz de reduzir os níveis de expressão de citocinas inflamatórias no intestino. Apesar de já ter sido demonstrada a diminuição de citocinas pró-inflamatórias circulantes em camundongos submetidos à colite experimental após tratamento com ATO, não há relatos na literatura sobre a modulação de citocinas no local da doença (AKTUNC et 
al., 2011). Desse modo, de maneira interessante, os mecanismos pelos quais a ATO preservou a integridade do epitélio intestinal provavelmente não estão relacionados com aqueles observados nos tratamentos contendo DX. Apesar de ter sido observada diminuição na expressão da molécula PPAR-y no intestino dos camundongos tratados com ATO isolada, estudos sugerem um papel protetor desta molécula na colite experimental induzida por DSS (ADACHI et al., 2006; SHAH; MORIMURA; GONZALEZ, 2007). Ainda, o uso de estatinas, em geral, parece aumentar a expressão de PPAR-y em diversos subtipos celulares tanto in vivo como in vitro (GRIP; JANCIAUSKIENE; LINDGREN, 2002; ZELVYTE et al., 2002). Portanto, novos estudos sobre o tema devem ser conduzidos para investigar a relação entre estatinas e PPAR-y no contexto da colite experimental.

Após constatar que os níveis de citocinas inflamatórias no cólon estavam diminuídos após as terapias contendo DX e inalteradas após o uso de ATO isolada, procurou-se estudar a distribuição e/ou comportamento de células $T$ nos camundongos expostos ao DSS. O tratamento combinado reduziu a frequência de células T auxiliares $\left(C D 4^{+}\right)$e aumentou células T citotóxicas $\left(C D 8^{+}\right)$em ambos os órgãos linfoides secundários, bem como reduziu células $T$ $\mathrm{CD}^{+}$produtoras de IFN-ץ nos LNM. Inesperadamente, o tratamento com DX isolada não causou alteração nessas populações celulares. Células $\mathrm{T} \mathrm{CD4}^{+}$podem desempenhar múltiplas funções, dentre elas auxiliar a resposta imune na produção de citocinas específicas que modulam as funções de células imunes inatas, bem como de outros componentes da imunidade adaptativa (LUCKHEERAM et al., 2012). A consequente diminuição do número e/ou função dessas células reduz as respostas contra agentes agressores. Neste contexto, somada à diminuição da expressão de citocinas inflamatórias no cólon discutida anteriormente, o microambiente intestinal após o tratamento combinado de DX e ATO tornouse menos inflamado, com reduzidos danos locais, posto que as lesões colônicas observadas na DII são resultado basicamente das reações inflamatórias exacerbadas que liberam diversas substâncias agressoras ao tecido. Entretanto, a regulação da reação inflamatória local e sistêmica mostrou-se benéfica apenas em curto prazo com a associação das drogas, provavelmente por diminuir a vigilância imunológica da mucosa e por facilitar invasões 
microbianas posteriores, que por sua vez, supostamente causaram a morte dos animais com o uso prolongado da terapia. Ainda, o aumento observado de células T citotóxicas nos LNM poderia auxiliar no combate a essa possível translocação bacteriana, porém, sozinhas, exerceriam efeitos limitados, além do que a migração daquelas células presentes no baço seria dificultada com o microambiente relativamente pobre em citocinas inflamatórias no cólon dos camundongos doentes. Ainda, a concentração de Fas- $L$ foi maior no cólon dos animais tratados concomitantemente com DX e ATO. Esta molécula, que está presente principalmente em células CD8+ e células NK (HASSIN et al., 2011; SMYTH et al., 2005), está relacionada com o aumento da ativação da via extrínseca de morte celular por apoptose em células susceptíveis (que expressam a molécula Fas) (ELMORE, 2007) e acompanha os resultados do aumento da frequência de células $\mathrm{CD}^{+}$. Desse modo, o provável aumento dos mecanismos de morte celular programada contribui para a imunossupressão, diminuindo a vigilância imunológica do epitélio intestinal e reforçando a hipótese de possível translocação futura de microorganismos intestinais após uso contínuo das terapias contendo DX.

Considerando o tratamento com ATO, de modo interessante, não houve alteração nos níveis de citocinas inflamatórias no cólon e na população de células CD4+ no baço e LNM. Entretanto ocorreu aumento da população de células CD4 ${ }^{+}$na LP e na frequência de células citotóxicas nos órgãos linfoides secundários, além da redução das células CD4+IFN- $\gamma^{+}$nos LNM. Assim, como visto até aqui, a melhora dos camundongos após uso de ATO isolada, bem como a manutenção da integridade do epitélio intestinal, pareceu ser devido às ações anti-inflamatórias moderadas sobre o sistema imune, que supostamente preservaram a eficiência da resposta imunológica, mantendo-a relativamente controlada. Corroborando os resultados, animais tratados com ATO isolada não apresentaram altos níveis de Fas-L no cólon, sugerindo que a regulação do sistema imune pelas estatinas é realizada por outros mecanismos que não envolvem a indução de morte celular (pelo menos por um dos mecanismos), mantendo, assim, a vigilância imunológica da barreira epitelial intestinal.

A partir disso, procurou-se observar se as células reguladoras poderiam ser as responsáveis por esse suposto "controle" da resposta imunológica intestinal após uso isolado 
de ATO. Entretanto, contrariamente ao que é observado na literatura, nenhum dos tratamentos foi capaz de aumentar significativamente a frequência de células Treg no baço e LNM dos camundongos doentes (BARRAT et al., 2002; MAUSNER-FAINBERG et al., 2008; MIRA et al., 2008). Além disso, questionou-se se as células de animais tratados com os diferentes esquemas farmacológicos poderiam estar mais susceptíveis a sinais reguladores, tais como os de células Treg. Assim, poderia-se supor que apesar da frequência de células Treg não ter sido afetada pelos diferentes tratamentos, a responsividade dos esplenócitos às mesmas poderia estar reduzida. Entretanto, as células Treg inibiram de modo muito semelhantes a proliferação de células de baço estimuladas provenientes de camundongos tratados com os diferentes esquemas terapêuticos, sendo esta inibição proporcional à quantidade de células Treg, como esperado.

Visto que os diferentes tratamentos com ATO exerceram efeitos importantes sobre a frequência e número de leucócitos, procuramos avaliar melhor o papel dessas drogas no comportamento dessas células in vitro. Confirmando os efeitos potencialmente imunossupressores da associação de DX e ATO, os experimentos mostraram uma diminuição da síntese de IL-6 por esplenócitos estimulados em cultura de modo mais acentuado do que com os tratamentos simples, semelhantemente ao que é encontrado na literatura (JAMEEL et al., 2013). Ainda, a concentração da citocina anti-inflamatória IL-10 apresentou um perfil oposto ao de IL-6, ou seja, a conjunção de DX e ATO aumentou a síntese da proteína, porém apenas quando baixas doses de ATO estavam presentes. O mesmo ocorreu com o tratamento isolado com a estatina em menor dose. Ainda, foi verificado que as alterações na síntese dessas citocinas foram devido aos efeitos imunomoduladores das drogas, uma vez que o ensaio de morte celular não mostrou diferenças significativas no número de células mortas com as diferentes concentrações e/ou combinações de DX e ATO.

A utilização de altas doses de estatina pareceu cessar a síntese de IL-10 por esplenócitos, provavelmente por diminuir a população de células com características de linfócitos, como observado no experimento de proliferação celular, onde a quantidade de

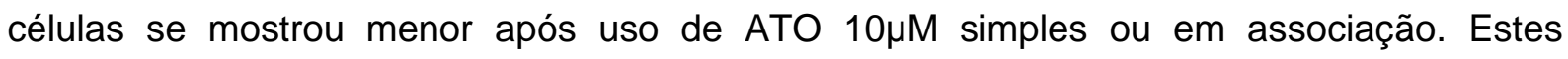


resultados contrastam com os achados de Jameel e colaboradores que observaram aumento da síntese de IL-10 com GC, nenhum efeito com a estatina e produção moderada com a associação das drogas in vitro, após 18 horas de cultura com células de sangue total estimuladas com PMA/ionomicina (JAMEEL et al., 2013). Entretanto, a dosagem de IL-10 no experimento ex vivo corroborou parcialmente os resultados do estudo supracitado, mostrando aumento na síntese de IL-10 após o tratamento in vivo com DX e reestimulação in vitro das células do baço por 72 horas, enquanto que houve pequena produção após uso de ATO e nenhuma alteração com o uso associado das drogas.

Diversos estudos mostram que IL-6 e IL-10 desempenham importante papel na DII. IL6 está aumentada durante a doença intestinal e está intimamente relacionada com a diferenciação de células Th17 (VELDHOEN et al., 2006) que, como discutido anteriormente, possui importante participação na patogênese da DII (EASTAFF-LEUNG et al., 2010; KOBAYASHI et al., 2008). Além disso, IL-6 parece ser essencial para o desenvolvimento de modelos murinos de colite (YAMAMOTO et al., 2000; YEN et al., 2006) e polimorfismos encontrados no gene codificador de IL-6 estão associados ao início da CD em pacientes pediátricos (SAGIV-FRIEDGUT et al., 2010). Ainda, a citocina anti-inflamatória IL-10 é sintetizada principalmente por células T reguladoras (Tregs). A ausência de IL-10 em células $\mathrm{T} \mathrm{FoxP}^{+}$de camundongos knockout condicionais leva ao desenvolvimento de colite espontânea nesses animais (RUBTSOV et al., 2008) e polimorfismos associados à menor síntese de IL-10 estão relacionados ao aumento da suscetibilidade de humanos à DII (TAGORE et al., 1999). Ademais, em outros modelos experimentais de DII, a diminuição de IL-10 parece estar diretamente associada ao aumento de citocinas inflamatórias, tais como a própria IL-6, IL-17 e TNF (KULLBERG et al., 2006). Apesar disso, estudos tem mostrado que pacientes com DII apresentam concentração sérica de IL-10 iguais aos de pacientes saudáveis, mas aumentada no período de remissão da doença (MITSUYAMA et al., 2006; SZKARADKIEWICZ et al., 2009). Sabidamente, DX e ATO inibem a produção de citocinas pró-inflamatórias, tais como a IL-6 (ALMAWI et al., 1996; INOUE et al., 2000). Desse modo, apesar de não ter sido avaliada a produção in vivo da síntese de IL-10, esses resultados 
sugerem que os esquemas terapêuticos contendo estatinas aumentam a síntese dos "sinais reguladores", tais como IL-10, os quais controlam as reações inflamatórias, ajudando a contextualizar nossos resultados in vivo.

Além disso, a combinação de ATO e DX em experimentos in vitro e a consequente modulação observada na população de células com características de linfócitos, tanto em número quanto em capacidade proliferativa, indicou que essa abordagem terapêutica é altamente eficaz no que se refere ao controle da inflamação e confirma que o uso clínico desse esquema terapêutico deve ser feito com cautela de modo a evitar a imunossupressão intensa. Blank e colaboradores observaram que a ATO inibe a proliferação de células T humanas estimuladas por superantígenos in vitro devido à diminuição da prenilação de proteínas (BLANK et al., 2007). A pequena alteração na taxa de proliferação de linfócitos induzida por GCs observada em nossos experimentos também já foi observada em outros estudos in vivo e in vitro (ASHWELL; LU; VACCHIO, 2000; CORRIGAN et al., 1991; KUNICKA et al., 1993). Aqui, nós também verificamos que a associação das drogas inibiu a proliferação de células $T$ murinas de maneira mais acentuada do que as estatinas isoladamente, sugerindo que essa adição possui maior eficácia do que as ações dessas drogas administradas individualmente.

Crocket e colaboradores (CROCKETT et al., 2012) discorreram bem sobre as limitações de seu estudo retrospectivo ao observarem que o uso de estatinas diminuiu a necessidade do uso de esteroides por pacientes com DII. Embora criterioso, os autores utilizaram dados de prontuários da população americana assistida por planos de saúde e, por não ser um estudo totalmente controlado, incluíram vieses muito importantes, tais como possibilidades de diagnósticos errôneos, falta de controle sobre o uso correto dos medicamentos, ausência no monitoramento na utilização de outras terapias e nos hábitos de vida dos pacientes, entre outros. Apesar disso, os nossos achados não são discordantes dos resultados deste referido estudo, uma vez que a associação de GCs e estatinas mostrou importantes efeitos imunomoduladores na DII experimental e nos estudos in vitro. Entretanto, ensaios clínicos mais controlados devem ser executados para verificar os reais efeitos dessa 
conjunção de drogas, atentando-se para as doses e intervalos utilizados, de modo a evitar a imunossupressão exacerbada dos usuários.

Embora os efeitos benéficos das estatinas no tratamento da DII não serem novidade, nenhum estudo até o momento avaliou a modulação da resposta imune de forma tão abrangente quanto este, que incluiu importantes análises in vivo, ex vivo e in vitro. Logo, apesar do número e da frequência de diversas populações celulares terem sido avaliados, ainda existe a necessidade de se estudar o comportamento de DCs, monócitos/macrófagos, células NK e as subpopulações específicas de células $T$, dentro do contexto da colite experimental induzida por DSS após os diferentes tratamentos. Embora a frequência destas populações celulares esteja alterada (e muitas vezes aumentada) no cólon de animais tratados com ATO isolada, elas devem estar relativamente hiporresponsivas aos sinais inflamatórios do microambiente intestinal, de modo a evitar os danos teciduais resultantes das reações imunológicas exacerbadas. Ao mesmo tempo, estas células devem estar suficientemente imunocompetentes para conter as complicações da doença. Ainda, torna-se indispensável avaliar as funções de células Treg de modo mais pormenorizado, além de verificar as alterações das concentrações de IL-10 no local inflamatório e/ou sistêmico e de IL-6 na corrente circulatória após as terapias para melhor contextualizar os resultados in vivo, in vitro e ex vivo.

Em conjunto, nossos resultados sugerem que as terapias contínuas com GCs isolados ou associados às estatinas deveriam ser a princípio evitadas na DII, até que doses terapêuticas e intervalos mais seguros possam ser instituídos, com base em novos estudos sobre o tema. Já o uso contínuo de ATO deveria ser estimulado, uma vez que a doença mostrou-se mais branda após a terapia e contribuiu com o aumento da sobrevivência dos animais doentes. Ainda, os efeitos em curto prazo com uso de GCs associados a estatinas pareceram reduzir a atividade ou eficiência do sistema imunológico por alterar a frequência e/ou número de diversas populações celulares, além de, supostamente, diminuir a vigilância imunológica no intestino grosso dos camundongos doentes. Já o uso isolado de estatinas pareceu exercer efeitos moderadamente anti-inflamatórios, mantendo a resposta imunológica 
eficiente, porém controlada. Como consequência, as estatinas contribuem para um maior equilíbrio dos processos pró- e anti-inflamatórios, resultando no sucesso terapêutico. 
6. CONCLUSÕES 


\section{CONCLUSÕES}

- O tratamento contínuo com a associação de estatinas e glicocorticoides na colite experimental não melhora o curso clínico da doença em longo prazo.

- O uso associado de estatinas e glicocorticoides melhora os aspectos clínicos, imunológicos e microscópicos após curtos períodos, além de exercer importantes efeitos sobre o comportamento de células in vitro devido às atividades fortemente antiinflamatórias e imunossupressoras decorrentes da associação das drogas.

- O uso isolado de estatinas recupera animais da colite experimental por causar efeitos anti-inflamatórios moderados, tanto in vivo como in vitro, mantendo a resposta imunológica eficiente e controlada. 


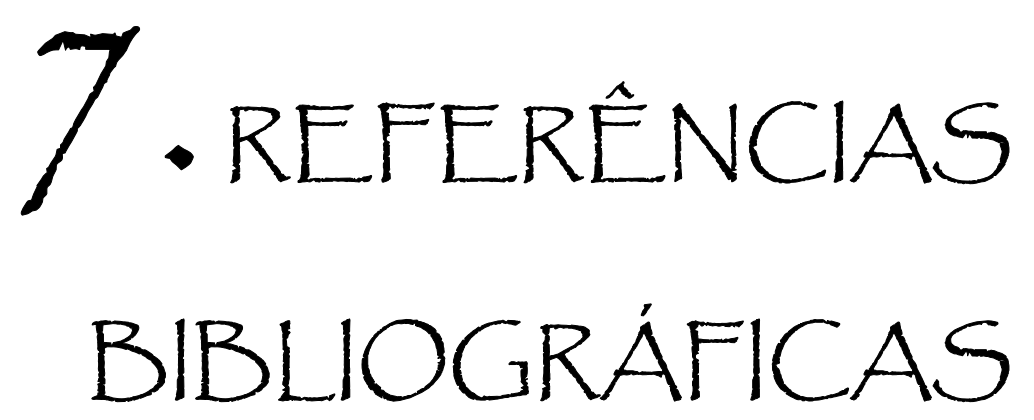




\section{Referências bibliográficas}

ABE, Y. et al. Simvastatin attenuates intestinal fibrosis independent of the anti-inflammatory effect by promoting fibroblast/myofibroblast apoptosis in the regeneration/healing process from TNBS-induced colitis. Dig Dis Sci, v. 57, n. 2, p. 335-44, Feb 2012.

ABRAHAM, C.; CHO, J. Interleukin-23/Th17 pathways and inflammatory bowel disease. Inflamm Bowel Dis, v. 15, n. 7, p. 1090-100, Jul 2009.

ADACHI, M. et al. Peroxisome proliferator activated receptor gamma in colonic epithelial cells protects against experimental inflammatory bowel disease. Gut, v. 55, n. 8, p. 1104-13, Aug 2006.

AGUILAR-SALINAS, C. A.; BARRETT, H.; SCHONFELD, G. Metabolic modes of action of the statins in the hyperlipoproteinemias. Atherosclerosis, v. 141, n. 2, p. 203-7, Dec 1998.

AHERN, P. P. et al. Interleukin-23 drives intestinal inflammation through direct activity on $\mathrm{T}$ cells. Immunity, v. 33, n. 2, p. 279-88, Aug 272010.

AJMAL, M. et al. Does statin usage reduce the risk of corticosteroid-related osteonecrosis in renal transplant population? Orthop Clin North Am, v. 40, n. 2, p. 235-9, Apr 2009.

AKTUNC, E. et al. The effect of atorvastatin and its role on systemic cytokine network in treatment of acute experimental colitis. Immunopharmacol Immunotoxicol, v. 33, n. 4, p. 667-75, Dec 2011.

ALMAWI, W. Y. et al. Regulation of cytokine and cytokine receptor expression by glucocorticoids. J Leukoc Biol, v. 60, n. 5, p. 563-72, Nov 1996.

ANDERSON, C. A. et al. Meta-analysis identifies 29 additional ulcerative colitis risk loci, increasing the number of confirmed associations to 47. Nat Genet, v. 43, n. 3, p. 246-52, Mar 2011.

ASCER, E. et al. Atorvastatin reduces proinflammatory markers in hypercholesterolemic patients. Atherosclerosis, v. 177, n. 1, p. 161-6, Nov 2004.

ASHWELL, J. D.; LU, F. W.; VACCHIO, M. S. Glucocorticoids in T cell development and function*. Annu Rev Immunol, v. 18, p. 309-45, 2000.

BAGHAEI, A. et al. Efficacy of Setarud (IMod), a novel drug with potent anti-toxic stress potential in rat inflammatory bowel disease and comparison with dexamethasone and infliximab. Indian J Biochem Biophys, v. 47, n. 4, p. 219-26, Aug 2010.

BAIN, C. C. et al. Resident and pro-inflammatory macrophages in the colon represent alternative context-dependent fates of the same Ly6Chi monocyte precursors. Mucosal Immunol, v. 6, n. 3, p. 498510, May 2013. 
BARRAT, F. J. et al. In vitro generation of interleukin 10-producing regulatory CD4(+) T cells is induced by immunosuppressive drugs and inhibited by T helper type 1 (Th1)- and Th2-inducing cytokines. J Exp Med, v. 195, n. 5, p. 603-16, Mar 42002.

BASSO, P. J. et al. Association among genetic predisposition, gut microbiota, and host immune response in the etiopathogenesis of inflammatory bowel disease. Brazilian Journal of Medical and Biological Research, v. 47, p. 727-737, 2014.

BAUMGART, D. C.; SANDBORN, W. J. Inflammatory bowel disease: clinical aspects and established and evolving therapies. Lancet, v. 369, n. 9573, p. 1641-57, May 122007.

BAUMGART, D. C. et al. Exaggerated inflammatory response of primary human myeloid dendritic cells to lipopolysaccharide in patients with inflammatory bowel disease. Clin Exp Immunol, v. 157, n. 3, p. 423-36, Sep 2009.

BEGUE, B. et al. Defective IL10 signaling defining a subgroup of patients with inflammatory bowel disease. Am J Gastroenterol, v. 106, n. 8, p. 1544-55, Aug 2011.

BENCHIMOL, E. I. et al. Epidemiology of pediatric inflammatory bowel disease: a systematic review of international trends. Inflamm Bowel Dis, v. 17, n. 1, p. 423-39, Jan 2011.

BENTO, A. F. et al. The selective nonpeptide CXCR2 antagonist SB225002 ameliorates acute experimental colitis in mice. J Leukoc Biol, v. 84, n. 4, p. 1213-21, Oct 2008.

BERNINK, J. H. et al. Human type 1 innate lymphoid cells accumulate in inflamed mucosal tissues. Nat Immunol, v. 14, n. 3, p. 221-9, Mar 2013.

BEWTRA, M. et al. Crohn's disease and ulcerative colitis are associated with elevated standardized mortality ratios: a meta-analysis. Inflamm Bowel Dis, v. 19, n. 3, p. 599-613, Mar 2013.

BIASI, F. et al. Inflammatory Bowel Disease: Mechanisms, Redox Considerations and Therapeutic Targets. Antioxid Redox Signal, Jan 112013.

BLANK, N. et al. Atorvastatin inhibits T cell activation through 3-hydroxy-3-methylglutaryl coenzyme A reductase without decreasing cholesterol synthesis. J Immunol, v. 179, n. 6, p. 3613-21, Sep 152007.

BRATTSAND, R.; LINDEN, M. Cytokine modulation by glucocorticoids: mechanisms and actions in cellular studies. Aliment Pharmacol Ther, v. 10 Suppl 2, p. 81-90; discussion 91-2, 1996.

BRINKKOETTER, P. T. et al. Atorvastatin interferes with activation of human CD4(+) T cells via inhibition of small guanosine triphosphatase (GTPase) activity and caspase-independent apoptosis. Clin Exp Immunol, v. 146, n. 3, p. 524-32, Dec 2006. 
BRYCESON, Y. T. et al. Cytolytic granule polarization and degranulation controlled by different receptors in resting NK cells. J Exp Med, v. 202, n. 7, p. 1001-12, Oct 32005.

BU, D. X.; GRIFFIN, G.; LICHTMAN, A. H. Mechanisms for the anti-inflammatory effects of statins. Curr Opin Lipidol, v. 22, n. 3, p. 165-70, Jun 2011.

BUCHANAN, J. et al. Managing the long term care of inflammatory bowel disease patients: The cost to European health care providers. J Crohns Colitis, v. 5, n. 4, p. 301-16, Aug 2011.

BUHAESCU, I.; IZZEDINE, H. Mevalonate pathway: a review of clinical and therapeutical implications. Clin Biochem, v. 40, n. 9-10, p. 575-84, Jun 2007.

BURISCH, J.; MUNKHOLM, P. Inflammatory bowel disease epidemiology. Curr Opin Gastroenterol, v. 29, n. 4, p. 357-62, Jul 2013.

BUSTELO, X. R.; SAUZEAU, V.; BERENJENO, I. M. GTP-binding proteins of the Rho/Rac family: regulation, effectors and functions in vivo. Bioessays, v. 29, n. 4, p. 356-70, Apr 2007.

CARD, T.; HUBBARD, R.; LOGAN, R. F. Mortality in inflammatory bowel disease: a populationbased cohort study. Gastroenterology, v. 125, n. 6, p. 1583-90, Dec 2003.

CHEN, X. et al. Differential response of murine CD4+CD25+ and CD4+CD25- T cells to dexamethasone-induced cell death. Eur J Immunol, v. 34, n. 3, p. 859-69, Mar 2004.

CHEN, Z.; O'SHEA, J. J. Th17 cells: a new fate for differentiating helper T cells. Immunol Res, v. 41, n. 2, p. 87-102, 2008.

CHO, S. J. et al. Simvastatin induces apoptosis in human colon cancer cells and in tumor xenografts, and attenuates colitis-associated colon cancer in mice. Int J Cancer, v. 123, n. 4, p. 951-7, Aug 152008.

CORRIGAN, C. J. et al. Glucocorticoid resistance in chronic asthma. Glucocorticoid pharmacokinetics, glucocorticoid receptor characteristics, and inhibition of peripheral blood $\mathrm{T}$ cell proliferation by glucocorticoids in vitro. Am Rev Respir Dis, v. 144, n. 5, p. 1016-25, Nov 1991.

CROCKETT, S. D. et al. Statins are associated with reduced use of steroids in inflammatory bowel disease: a retrospective cohort study. Inflamm Bowel Dis, v. 18, n. 6, p. 1048-56, Jun 2012.

CROSBIE, J. et al. Statins inhibit proliferation and cytotoxicity of a human leukemic natural killer cell line. Biomark Res, v. 1, n. 1, p. 33, 2013.

CURTIS, J. R. et al. Population-based assessment of adverse events associated with long-term glucocorticoid use. Arthritis Rheum, v. 55, n. 3, p. 420-6, Jun 152006. 
DE IUDICIBUS, S. et al. Molecular mechanism of glucocorticoid resistance in inflammatory bowel disease. World J Gastroenterol, v. 17, n. 9, p. 1095-108, Mar 72011.

DE JAGER, P. L. et al. The role of the Toll receptor pathway in susceptibility to inflammatory bowel diseases. Genes Immun, v. 8, n. 5, p. 387-97, Jul 2007.

DE JONG, E. C. et al. Corticosteroids inhibit the production of inflammatory mediators in immature monocyte-derived DC and induce the development of tolerogenic DC3. J Leukoc Biol, v. 66, n. 2, p. 201-4, Aug 1999.

DE LOECKER, I.; PREISER, J. C. Statins in the critically ill. Ann Intensive Care, v. 2, n. 1, p. 19, 2012.

DESVERGNE, B.; WAHLI, W. Peroxisome proliferator-activated receptors: nuclear control of metabolism. Endocr Rev, v. 20, n. 5, p. 649-88, Oct 1999.

DIGNASS, A. et al. Second European evidence-based consensus on the diagnosis and management of ulcerative colitis part 1: definitions and diagnosis. J Crohns Colitis, v. 6, n. 10, p. 965-90, Dec 2012.

DIONNE, S. et al. Colonic explant production of IL-1and its receptor antagonist is imbalanced in inflammatory bowel disease (IBD). Clin Exp Immunol, v. 112, n. 3, p. 435-42, Jun 1998.

EASTAFF-LEUNG, N. et al. Foxp3+ regulatory T cells, Th17 effector cells, and cytokine environment in inflammatory bowel disease. J Clin Immunol, v. 30, n. 1, p. 80-9, Jan 2010.

EK, W. E.; D'AMATO, M.; HALFVARSON, J. The history of genetics in inflammatory bowel disease. Ann Gastroenterol, v. 27, n. 4, p. 294-303, 2014.

ELLIOTT, P.; PETERS, R. F.; WHITE, A. M. A study of the relationship between glucocorticoidinduced weight loss in rats and the activity of skeletal-muscle and cardiac-muscle ribosomes in vitro. Biochem J, v. 125, n. 4, p. 106P-107P, Dec 1971.

ELMORE, S. Apoptosis: a review of programmed cell death. Toxicol Pathol, v. 35, n. 4, p. 495-516, Jun 2007.

ELSHEIKH, W. et al. Dextran sulfate sodium induces pan-gastroenteritis in rodents: implications for studies of colitis. J Physiol Pharmacol, v. 63, n. 5, p. 463-9, Oct 2012.

FAKHRAEI, N. et al. Protective effect of hydroalcoholic olive leaf extract on experimental model of colitis in rat: involvement of nitrergic and opioidergic systems. Phytother Res, v. 28, n. 9, p. 1367-73, Sep 2014.

FANTUZZI, G.; GHEZZI, P. Glucocorticoids as cytokine inhibitors: role in neuroendocrine control and therapy of inflammatory diseases. Mediators Inflamm, v. 2, n. 4, p. 263-70, 1993. 
FINA, D. et al. Regulation of gut inflammation and th17 cell response by interleukin-21. Gastroenterology, v. 134, n. 4, p. 1038-48, Apr 2008.

FINK, L. N.; FROKIAER, H. Dendritic cells from Peyer's patches and mesenteric lymph nodes differ from spleen dendritic cells in their response to commensal gut bacteria. Scand J Immunol, v. 68, n. 3, p. 270-9, Sep 2008.

FONTENOT, J. D. et al. Regulatory T cell lineage specification by the forkhead transcription factor foxp3. Immunity, v. 22, n. 3, p. 329-41, Mar 2005.

FRANCHI, L. et al. Intracellular NOD-like receptors in innate immunity, infection and disease. Cell Microbiol, v. 10, n. 1, p. 1-8, Jan 2008.

FRANKE, A. et al. Genome-wide meta-analysis increases to 71 the number of confirmed Crohn's disease susceptibility loci. Nat Genet, v. 42, n. 12, p. 1118-25, Dec 2010.

FUJINO, S. et al. Increased expression of interleukin 17 in inflammatory bowel disease. Gut, v. 52, n. 1, p. 65-70, Jan 2003.

FURUSAWA, Y. et al. Commensal microbe-derived butyrate induces the differentiation of colonic regulatory T cells. Nature, Nov 132013.

FUSS, I. J. Is the Th1/Th2 paradigm of immune regulation applicable to IBD? Inflamm Bowel Dis, v. 14, n. S2, p. S110-S112, 2008.

GALON, J. et al. Gene profiling reveals unknown enhancing and suppressive actions of glucocorticoids on immune cells. FASEB J, v. 16, n. 1, p. 61-71, Jan 2002.

GALVEZ, J. Role of Th17 Cells in the Pathogenesis of Human IBD. ISRN Inflamm, v. 2014, p. 928461, 2014.

GARCIA-MARTINEZ, A. et al. Treatment with statins does not exhibit a clinically relevant corticosteroid-sparing effect in patients with giant cell arteritis. Arthritis Rheum, v. 51, n. 4, p. 674-8, Aug 152004.

GEBOES, K. What histologic features best differentiate Crohn's disease from ulcerative colitis? Inflamm Bowel Dis, v. 14 Suppl 2, p. S168-9, Oct 2008.

GENSLER, L. S. Glucocorticoids: complications to anticipate and prevent. Neurohospitalist, v. 3, n. 2, p. 92-7, Apr 2013.

GEROVA, V. A. et al. Increased intestinal permeability in inflammatory bowel diseases assessed by iohexol test. World J Gastroenterol, v. 17, n. 17, p. 2211-5, May 72011. 
GHITTONI, R. et al. Simvastatin inhibits the MHC class II pathway of antigen presentation by impairing Ras superfamily GTPases. Eur J Immunol, v. 36, n. 11, p. 2885-93, Nov 2006.

GOMEZ, S. I. et al. The pleiotropic effects of the hydroxy-methyl-glutaryl-CoA reductase inhibitors in renal disease. Int J Nephrol Renovasc Dis, v. 7, p. 123-30, 2014.

GRIP, O.; JANCIAUSKIENE, S. Atorvastatin reduces plasma levels of chemokine (CXCL10) in patients with Crohn's disease. PLoS One, v. 4, n. 5, p. e5263, 2009.

GRIP, O.; JANCIAUSKIENE, S.; BREDBERG, A. Use of atorvastatin as an anti-inflammatory treatment in Crohn's disease. Br J Pharmacol, v. 155, n. 7, p. 1085-92, Dec 2008.

GRIP, O.; JANCIAUSKIENE, S.; LINDGREN, S. Atorvastatin activates PPAR-gamma and attenuates the inflammatory response in human monocytes. Inflamm Res, v. 51, n. 2, p. 58-62, Feb 2002.

. Circulating monocytes and plasma inflammatory biomarkers in active Crohn's disease: elevated oxidized low-density lipoprotein and the anti-inflammatory effect of atorvastatin. Inflamm Bowel Dis, v. 10, n. 3, p. 193-200, May 2004.

GROVER, H. S.; LUTHRA, S.; MAROO, S. Are statins really wonder drugs? J Formos Med Assoc, v. 113, n. 12, p. 892-8, Dec 2014.

GROVER, H. S. et al. The pleotropic role of statins: Could it be the imminent host modulation agent in periodontics? Dent Res J (Isfahan), v. 10, n. 2, p. 143-8, Mar 2013.

GUPTA, H.; BHANDARI, D.; SHARMA, A. Recent trends in oral drug delivery: a review. Recent Pat Drug Deliv Formul, v. 3, n. 2, p. 162-73, Jun 2009.

HAKAMADA-TAGUCHI, R. et al. Inhibition of hydroxymethylglutaryl-coenzyme a reductase reduces Th1 development and promotes Th2 development. Circ Res, v. 93, n. 10, p. 948-56, Nov 142003.

HANAUER, S. B. Inflammatory bowel disease: epidemiology, pathogenesis, and therapeutic opportunities. Inflamm Bowel Dis, v. 12 Suppl 1, p. S3-9, Jan 2006.

HASSELGREN, P. O. Glucocorticoids and muscle catabolism. Curr Opin Clin Nutr Metab Care, v. 2, n. 3, p. 201-5, May 1999.

HASSIN, D. et al. Cytotoxic T lymphocyte perforin and Fas ligand working in concert even when Fas ligand lytic action is still not detectable. Immunology, v. 133, n. 2, p. 190-6, Jun 2011.

HAUSMANN, M. et al. Toll-like receptors 2 and 4 are up-regulated during intestinal inflammation. Gastroenterology, v. 122, n. 7, p. 1987-2000, Jun 2002. 
HEIDER, D. et al. Insights into the classification of small GTPases. Adv Appl Bioinform Chem, v. 3, p. 15-24, 2010.

HEINSBROEK, S. E.; GORDON, S. The role of macrophages in inflammatory bowel diseases. Expert Rev Mol Med, v. 11, p. e14, 2009.

HELLER, F. et al. Interleukin-13 is the key effector Th2 cytokine in ulcerative colitis that affects epithelial tight junctions, apoptosis, and cell restitution. Gastroenterology, v. 129, n. 2, p. 550-64, Aug 2005.

HENDRICKSON, B. A.; GOKHALE, R.; CHO, J. H. Clinical aspects and pathophysiology of inflammatory bowel disease. Clin Microbiol Rev, v. 15, n. 1, p. 79-94, Jan 2002.

HERNANDEZ-DIAZ, S.; RODRIGUEZ, L. A. Steroids and risk of upper gastrointestinal complications. Am J Epidemiol, v. 153, n. 11, p. 1089-93, Jun 12001.

HIRSCHBERG, T.; RANDAZZO, B.; HIRSCHBERG, H. Effects of methylprednisolone on the in vitro induction and function of suppressor cells in man. Scand J Immunol, v. 12, n. 1, p. 33-9, 1980.

HOLD, G. L. et al. Role of the gut microbiota in inflammatory bowel disease pathogenesis: what have we learnt in the past 10 years? World J Gastroenterol, v. 20, n. 5, p. 1192-210, Feb 72014.

HU, Y. et al. Function of regulatory T-cells improved by dexamethasone in Graves' disease. Eur $\mathbf{J}$ Endocrinol, v. 166, n. 4, p. 641-6, Apr 2012.

HUGOT, J. P. et al. Association of NOD2 leucine-rich repeat variants with susceptibility to Crohn's disease. Nature, v. 411, n. 6837, p. 599-603, May 312001.

HUSCHER, D. et al. Dose-related patterns of glucocorticoid-induced side effects. Ann Rheum Dis, v. 68, n. 7, p. 1119-24, Jul 2009.

IKEDA, T. et al. Immunological mechanisms of corticosteroid therapy in chronic active hepatitis: analysis of peripheral blood suppressor $\mathrm{T}$-cell and interleukin 2 activities. Clin Immunol Immunopathol, v. 48, n. 3, p. 371-9, Sep 1988.

INOUE, I. et al. Lipophilic HMG-CoA reductase inhibitor has an anti-inflammatory effect: reduction of MRNA levels for interleukin-1beta, interleukin-6, cyclooxygenase-2, and p22phox by regulation of peroxisome proliferator-activated receptor alpha (PPARalpha) in primary endothelial cells. Life Sci, v. 67, n. 8, p. 863-76, Jul 142000.

ITO, R. et al. Involvement of IL-17A in the pathogenesis of DSS-induced colitis in mice. Biochem Biophys Res Commun, v. 377, n. 1, p. 12-6, Dec 52008. 
IWASAKI, A.; MEDZHITOV, R. Toll-like receptor control of the adaptive immune responses. Nat Immunol, v. 5, n. 10, p. 987-95, Oct 2004.

JAMEEL, A. et al. Statin Modulation of Human T-Cell Proliferation, IL-1 and IL-17 Production, and IFN- T Cell Expression: Synergy with Conventional Immunosuppressive Agents. International Journal of Inflammation, v. 2013, p. 11, 2013.

JANG, M. H. et al. CCR7 is critically important for migration of dendritic cells in intestinal lamina propria to mesenteric lymph nodes. J Immunol, v. 176, n. 2, p. 803-10, Jan 152006.

JESS, T. et al. Decreasing risk of colorectal cancer in patients with inflammatory bowel disease over 30 years. Gastroenterology, v. 143, n. 2, p. 375-81 e1; quiz e13-4, Aug 2012.

KAGAMI, S. et al. Protein geranylgeranylation regulates the balance between Th17 cells and Foxp3+ regulatory T cells. Int Immunol, v. 21, n. 6, p. 679-89, Jun 2009.

KALLA, R. et al. Crohn's disease. BMJ, v. 349, p. g6670, 2014.

KANAGARAJAN, N. et al. Disease modifying effect of statins in dextran sulfate sodium model of mouse colitis. Inflamm Res, v. 57, n. 1, p. 34-8, Jan 2008.

KAPPELMAN, M. D. et al. Recent trends in the prevalence of Crohn's disease and ulcerative colitis in a commercially insured US population. Dig Dis Sci, v. 58, n. 2, p. 519-25, Feb 2013.

KARAGIANNIDIS, C. et al. Glucocorticoids upregulate FOXP3 expression and regulatory T cells in asthma. J Allergy Clin Immunol, v. 114, n. 6, p. 1425-33, Dec 2004.

KARLINGER, K. et al. The epidemiology and the pathogenesis of inflammatory bowel disease. Eur J Radiol, v. 35, n. 3, p. 154-67, Sep 2000.

KIESLER, P.; FUSS, I. J.; STROBER, W. Experimental Models of Inflammatory Bowel Diseases. CMGH Cellular and Molecular Gastroenterology and Hepatology, v. 1, n. 2, p. 154-170, 2015.

KIESSLICH, R. et al. Local barrier dysfunction identified by confocal laser endomicroscopy predicts relapse in inflammatory bowel disease. Gut, v. 61, n. 8, p. 1146-53, Aug 2012.

KIM, J. J. et al. Investigating intestinal inflammation in DSS-induced model of IBD. J Vis Exp, n. 60, 2012.

KOBASHIGAWA, J. A. et al. Effect of pravastatin on outcomes after cardiac transplantation. N Engl J Med, v. 333, n. 10, p. 621-7, Sep 71995. 
KOBAYASHI, T. et al. IL23 differentially regulates the Th1/Th17 balance in ulcerative colitis and Crohn's disease. Gut, v. 57, n. 12, p. 1682-9, Dec 2008.

KOJOUHAROFF, G. et al. Neutralization of tumour necrosis factor (TNF) but not of IL-1 reduces inflammation in chronic dextran sulphate sodium-induced colitis in mice. Clin Exp Immunol, v. 107, n. 2, p. 353-8, Feb 1997.

KONDAMUDI, P. K. et al. Drugs as causative agents and therapeutic agents in inflammatory bowel disease. Acta Pharmaceutica Sinica B, v. 3, n. 5, p. 289-296, 2013.

KOSTYO, J. L.; REDMOND, A. F. Role of protein synthesis in the inhibitory action of adrenal steroid hormones on amino acid transport by muscle. Endocrinology, v. 79, n. 3, p. 531-40, Sep 1966.

KOZUCH, P. L.; HANAUER, S. B. Treatment of inflammatory bowel disease: a review of medical therapy. World J Gastroenterol, v. 14, n. 3, p. 354-77, Jan 212008.

KRAAIJ, M. D. et al. Dexamethasone increases ROS production and T cell suppressive capacity by anti-inflammatory macrophages. Mol Immunol, v. 49, n. 3, p. 549-57, Dec 2011.

KULLBERG, M. C. et al. IL-23 plays a key role in Helicobacter hepaticus-induced T cell-dependent colitis. J Exp Med, v. 203, n. 11, p. 2485-94, Oct 302006.

KUMAR, H.; KAWAI, T.; AKIRA, S. Pathogen recognition in the innate immune response. Biochem J, v. 420, n. 1, p. 1-16, May 152009.

KUNICKA, J. E. et al. Immunosuppression by glucocorticoids: inhibition of production of multiple lymphokines by in vivo administration of dexamethasone. Cell Immunol, v. 149, n. 1, p. 39-49, Jun 1993.

LANGHOLZ, E. Current trends in inflammatory bowel disease: the natural history. Therap Adv Gastroenterol, v. 3, n. 2, p. 77-86, Mar 2010.

LAROUI, H. et al. Dextran sodium sulfate (DSS) induces colitis in mice by forming nanolipocomplexes with medium-chain-length fatty acids in the colon. PLoS One, v. 7, n. 3, p. e32084, 2012.

LATELLA, G.; PAPI, C. Crucial steps in the natural history of inflammatory bowel disease. World J Gastroenterol, v. 18, n. 29, p. 3790-9, Aug 72012.

LAUFS, U. et al. Upregulation of endothelial nitric oxide synthase by HMG CoA reductase inhibitors. Circulation, v. 97, n. 12, p. 1129-35, Mar 311998.

LAUFS, U.; LIAO, J. K. Post-transcriptional regulation of endothelial nitric oxide synthase mRNA stability by Rho GTPase. J Biol Chem, v. 273, n. 37, p. 24266-71, Sep 111998. 
LEE, D. et al. Diet in the Pathogenesis and Treatment of Inflammatory Bowel Diseases. Gastroenterology, Jan 152015.

LEE, J. Y. et al. Simvastatin inhibits NF-kappaB signaling in intestinal epithelial cells and ameliorates acute murine colitis. Int Immunopharmacol, v. 7, n. 2, p. 241-8, Feb 2007.

LEVINE, J. S.; BURAKOFF, R. Extraintestinal manifestations of inflammatory bowel disease. Gastroenterol Hepatol (N Y), v. 7, n. 4, p. 235-41, Apr 2011.

LIANG, S. C. et al. Interleukin (IL)-22 and IL-17 are coexpressed by Th17 cells and cooperatively enhance expression of antimicrobial peptides. J Exp Med, v. 203, n. 10, p. 2271-9, Oct 22006.

LIU, W. et al. CD127 expression inversely correlates with FoxP3 and suppressive function of human CD4+ T reg cells. J Exp Med, v. 203, n. 7, p. 1701-11, Jul 102006.

LIU, X. et al. Effects of HMG-CoA reductase inhibitor on experimental autoimmune myocarditis. Cardiovasc Drugs Ther, v. 26, n. 2, p. 121-30, Apr 2012.

LIU, Z. et al. The increased expression of IL-23 in inflammatory bowel disease promotes intraepithelial and lamina propria lymphocyte inflammatory responses and cytotoxicity. J Leukoc Biol, v. 89, n. 4, p. 597-606, Apr 2011.

LIU, Z. et al. Il-21 enhances NK cell activation and cytolytic activity and induces Th17 cell differentiation in inflammatory bowel disease. Inflamm Bowel Dis, v. 15, n. 8, p. 1133-44, Aug 2009.

LIVAK, K. J.; SCHMITTGEN, T. D. Analysis of relative gene expression data using real-time quantitative PCR and the 2(-Delta Delta C(T)) Method. Methods, v. 25, n. 4, p. 402-8, Dec 2001.

LOFTUS, E. V., JR.; SANDBORN, W. J. Epidemiology of inflammatory bowel disease. Gastroenterol Clin North Am, v. 31, n. 1, p. 1-20, Mar 2002.

LONG, S. A.; BUCKNER, J. H. CD4+FOXP3+ T regulatory cells in human autoimmunity: more than a numbers game. J Immunol, v. 187, n. 5, p. 2061-6, Sep 12011.

LONGUI, C. A. Glucocorticoid therapy: minimizing side effects. J Pediatr (Rio J), v. 83, n. 5 Suppl, p. S163-77, Nov 2007.

LOPEZ-PEDRERA, C. et al. To cardiovascular disease and beyond: new therapeutic perspectives of statins in autoimmune diseases and cancer. Curr Drug Targets, v. 13, n. 6, p. 829-41, Jun 2012.

LOWENBERG, $M$. et al. Glucocorticoid signaling: a nongenomic mechanism for T-cell immunosuppression. Trends Mol Med, v. 13, n. 4, p. 158-63, Apr 2007. 
LUCKHEERAM, R. V. et al. CD4(+)T cells: differentiation and functions. Clin Dev Immunol, v. 2012, p. 925135, 2012.

M'KOMA, A. E. Inflammatory bowel disease: an expanding global health problem. Clin Med Insights Gastroenterol, v. 6, p. 33-47, 2013.

MAHAdeVAn, U. Medical treatment of ulcerative colitis. Clin Colon Rectal Surg, v. 17, n. 1, p. 719, Feb 2004.

MAJI, D. et al. Safety of statins. Indian J Endocrinol Metab, v. 17, n. 4, p. 636-46, Jul 2013.

MALOY, K. J.; POWRIE, F. Intestinal homeostasis and its breakdown in inflammatory bowel disease. Nature, v. 474, n. 7351, p. 298-306, Jun 162011.

MANEECHOTESUWAN, K. et al. Statins enhance the anti-inflammatory effects of inhaled corticosteroids in asthmatic patients through increased induction of indoleamine 2, 3-dioxygenase. $\mathbf{J}$ Allergy Clin Immunol, v. 126, n. 4, p. 754-762 e1, Oct 2010.

MANEECHOTESUWAN, K. et al. Statins enhance the effects of corticosteroids on the balance between regulatory T cells and Th17 cells. Clin Exp Allergy, v. 43, n. 2, p. 212-22, Feb 2013.

MANN, E. R.; LI, X. Intestinal antigen-presenting cells in mucosal immune homeostasis: crosstalk between dendritic cells, macrophages and B-cells. World J Gastroenterol, v. 20, n. 29, p. 9653-64, Aug 72014.

MARTINEZ-MONTIEL MDEL, P.; GOMEZ-GOMEZ, G. J.; FLORES, A. I. Therapy with stem cells in inflammatory bowel disease. World J Gastroenterol, v. 20, n. 5, p. 1211-27, Feb 72014.

MARTINS, N. B.; PEPPERCORN, M. A. Inflammatory bowel disease. Am J Manag Care, v. 10, n. 8, p. 544-52, Aug 2004.

MAUSNER-FAINBERG, $\mathrm{K}$. et al. The effect of HMG-CoA reductase inhibitors on naturally occurring CD4+CD25+ T cells. Atherosclerosis, v. 197, n. 2, p. 829-39, Apr 2008.

MCHUGH, R. S. et al. CD4(+)CD25(+) immunoregulatory T cells: gene expression analysis reveals a functional role for the glucocorticoid-induced TNF receptor. Immunity, v. 16, n. 2, p. 311-23, Feb 2002.

MELGAR, S. et al. Validation of murine dextran sulfate sodium-induced colitis using four therapeutic agents for human inflammatory bowel disease. Int Immunopharmacol, v. 8, n. 6, p. 836-44, Jun 2008.

MENG, X. et al. Statins induce the accumulation of regulatory T cells in atherosclerotic plaque. Mol Med, v. 18, p. 598-605, 2012. 
MERAD, M. et al. The dendritic cell lineage: ontogeny and function of dendritic cells and their subsets in the steady state and the inflamed setting. Annu Rev Immunol, v. 31, p. 563-604, 2013.

MIGLIORATI, G. et al. Dexamethasone induces apoptosis in mouse natural killer cells and cytotoxic T lymphocytes. Immunology, v. 81, n. 1, p. 21-6, Jan 1994.

MIRA, E. et al. Statins induce regulatory $\mathrm{T}$ cell recruitment via a CCL1 dependent pathway. J Immunol, v. 181, n. 5, p. 3524-34, Sep 12008.

MITSUYAMA, K. et al. Interleukin-10 in the pathophysiology of inflammatory bowel disease: increased serum concentrations during the recovery phase. Mediators Inflamm, v. 2006, n. 6, p. 26875, 2006.

MOGHADAM-KIA, S.; WERTH, V. P. Prevention and treatment of systemic glucocorticoid side effects. Int J Dermatol, v. 49, n. 3, p. 239-48, Mar 2010.

MOLODECKY, N. A. et al. Increasing incidence and prevalence of the inflammatory bowel diseases with time, based on systematic review. Gastroenterology, v. 142, n. 1, p. 46-54 e42; quiz e30, Jan 2012.

MOWAT, C. et al. Guidelines for the management of inflammatory bowel disease in adults. Gut, v. 60, n. 5, p. 571-607, May 2011.

MUNKHOLM, P. et al. Frequency of glucocorticoid resistance and dependency in Crohn's disease. Gut, v. 35, n. 3, p. 360-2, Mar 1994.

NACI, H.; BRUGTS, J.; ADES, T. Comparative tolerability and harms of individual statins: a studylevel network meta-analysis of 246955 participants from 135 randomized, controlled trials. Circ Cardiovasc Qual Outcomes, v. 6, n. 4, p. 390-9, Jul 2013.

NAKASE, H.; YOSHINO, T.; MATSUURA, M. Role in calcineurin inhibitors for inflammatory bowel disease in the biologics era: when and how to use. Inflamm Bowel Dis, v. 20, n. 11, p. 2151-6, Nov 2014.

NARUM, S.; WESTERGREN, T.; KLEMP, M. Corticosteroids and risk of gastrointestinal bleeding: a systematic review and meta-analysis. BMJ Open, v. 4, n. 5, p. e004587, 2014.

NEURATH, M. F. Cytokines in inflammatory bowel disease. Nat Rev Immunol, v. 14, n. 5, p. 329-42, May 2014.

NEURATH, M. F. et al. Antibodies to interleukin 12 abrogate established experimental colitis in mice. J Exp Med, v. 182, n. 5, p. 1281-90, Nov 11995. 
NG, S. C. et al. Incidence and phenotype of inflammatory bowel disease based on results from the Asiapacific Crohn's and colitis epidemiology study. Gastroenterology, v. 145, n. 1, p. 158-165 e2, Jul 2013.

NGUYEN, G. C.; CHONG, C. A.; CHONG, R. Y. National estimates of the burden of inflammatory bowel disease among racial and ethnic groups in the United States. J Crohns Colitis, Sep 242013.

NIESS, J. H. Role of mucosal dendritic cells in inflammatory bowel disease. World J Gastroenterol, v. 14, n. 33, p. 5138-48, Sep 72008.

NIESS, J. H. et al. CX3CR1-mediated dendritic cell access to the intestinal lumen and bacterial clearance. Science, v. 307, n. 5707, p. 254-8, Jan 142005.

NISHIYORI, A.; NAGAKURA, Y.; ICHIKAWA, K. Piroxicam accelerates development of colitis in T-cell receptor alpha chain-deficient mice. Eur J Pharmacol, v. 615, n. 1-3, p. 241-5, Aug 12009.

NURIEVA, R. et al. Essential autocrine regulation by IL-21 in the generation of inflammatory T cells. Nature, v. 448, n. 7152, p. 480-3, Jul 262007.

O'TOOLE, A.; KORZENIK, J. Environmental triggers for IBD. Current Gastroenterology Reports, v. 16, n. 7, p. 396, 2014.

ODES, S. How expensive is inflammatory bowel disease? A critical analysis. World J Gastroenterol, v. 14, n. 43, p. 6641-7, Nov 212008.

OTT, S. J. et al. Reduction in diversity of the colonic mucosa associated bacterial microflora in patients with active inflammatory bowel disease. Gut, v. 53, n. 5, p. 685-93, May 2004.

PARENTE, J. M. et al. Inflammatory bowel disease in an underdeveloped region of Northeastern Brazil. World J Gastroenterol, v. 21, n. 4, p. 1197-206, Jan 282015.

PEDERSEN, G. et al. Expression of Toll-like receptor 9 and response to bacterial CpG oligodeoxynucleotides in human intestinal epithelium. Clin Exp Immunol, v. 141, n. 2, p. 298-306, Aug 2005.

PERSE, M.; CERAR, A. Dextran sodium sulphate colitis mouse model: traps and tricks. J Biomed Biotechnol, v. 2012, p. 718617, 2012.

PFEFFER, M. A. et al. Safety and tolerability of pravastatin in long-term clinical trials: prospective Pravastatin Pooling (PPP) Project. Circulation, v. 105, n. 20, p. 2341-6, May 212002.

PIERIK, M. et al. Toll-like receptor-1, -2 , and -6 polymorphisms influence disease extension in inflammatory bowel diseases. Inflamm Bowel Dis, v. 12, n. 1, p. 1-8, Jan 2006. 
PRADO, C. et al. Dexamethasone upregulates FOXP3 expression without increasing regulatory activity. Immunobiology, v. 216, n. 3, p. 386-92, Mar 2011.

PRIDEAUX, L. et al. Serological antibodies in inflammatory bowel disease: a systematic review. Inflamm Bowel Dis, v. 18, n. 7, p. 1340-55, Jul 2012.

PRIDEAUX, L. et al. Inflammatory bowel disease in Asia: a systematic review. J Gastroenterol Hepatol, v. 27, n. 8, p. 1266-80, Aug 2012.

RAEMER, P. C.; KOHL, K.; WATZL, C. Statins inhibit NK-cell cytotoxicity by interfering with LFA1-mediated conjugate formation. Eur J Immunol, v. 39, n. 6, p. 1456-65, Jun 2009.

RAIMONDI, G. et al. Regulated compartmentalization of programmed cell death-1 discriminates CD4+CD25+ resting regulatory T cells from activated T cells. J Immunol, v. 176, n. 5, p. 2808-16, Mar 12006.

READ, S.; MALMSTROM, V.; POWRIE, F. Cytotoxic T lymphocyte-associated antigen 4 plays an essential role in the function of $\mathrm{CD} 25(+) \mathrm{CD} 4(+)$ regulatory cells that control intestinal inflammation. $\mathbf{J}$ Exp Med, v. 192, n. 2, p. 295-302, Jul 172000.

REINECKER, H. C. et al. Monocyte-chemoattractant protein 1 gene expression in intestinal epithelial cells and inflammatory bowel disease mucosa. Gastroenterology, v. 108, n. 1, p. 40-50, Jan 1995.

REUTER, K. C. et al. Selective glucocorticoid receptor agonists for the treatment of inflammatory bowel disease: studies in mice with acute trinitrobenzene sulfonic acid colitis. J Pharmacol Exp Ther, v. 341, n. 1, p. 68-80, Apr 2012.

RHEN, T.; CIDLOWSKI, J. A. Antiinflammatory action of glucocorticoids--new mechanisms for old drugs. N Engl J Med, v. 353, n. 16, p. 1711-23, Oct 202005.

RODRIGUEZ-MORANTA, F.; SORIANO-IZQUIERDO, A.; GUARDIOLA, J. [Current status of treatment of inflammatory bowel disease]. Cir Esp, v. 82, n. 5, p. 254-9, Nov 2007.

ROGLANS, N. et al. Atorvastatin treatment induced peroxisome proliferator-activated receptor alpha expression and decreased plasma nonesterified fatty acids and liver triglyceride in fructose-fed rats. $\mathbf{J}$ Pharmacol Exp Ther, v. 302, n. 1, p. 232-9, Jul 2002.

RUBTSOV, Y. P. et al. Regulatory T cell-derived interleukin-10 limits inflammation at environmental interfaces. Immunity, v. 28, n. 4, p. 546-58, Apr 2008.

RUGTVEIT, J. et al. Increased macrophage subset in inflammatory bowel disease: apparent recruitment from peripheral blood monocytes. Gut, v. 35, n. 5, p. 669-74, May 1994. 
RUSSELL, R. K.; SATSANGI, J. Does IBD run in families? Inflamm Bowel Dis, v. 14, n. S2, p. S20S21, 2008.

SAGIV-FRIEDGUT, K. et al. Early-onset Crohn disease is associated with male sex and a polymorphism in the IL-6 promoter. J Pediatr Gastroenterol Nutr, v. 50, n. 1, p. 22-6, Jan 2010.

SALEH, M.; ELSON, C. O. Experimental inflammatory bowel disease: insights into the host-microbiota dialog. Immunity, v. 34, n. 3, p. 293-302, Mar 252011.

SALES-CAMPOS, $\mathrm{H}$. et al. Classical and recent advances in the treatment of inflammatory bowel diseases. Braz J Med Biol Res, v. 48, n. 2, p. 96-107, Feb 2015.

SANDS, B. E.; GRABERT, S. Epidemiology of inflammatory bowel disease and overview of pathogenesis. Med Health R I, v. 92, n. 3, p. 73-7, Mar 2009.

SANN, H. et al. Efficacy of drugs used in the treatment of IBD and combinations thereof in acute DSSinduced colitis in mice. Life Sci, v. 92, n. 12, p. 708-18, Apr 92013.

SARTOR, R. B. Microbial influences in inflammatory bowel diseases. Gastroenterology, v. 134, n. 2, p. 577-94, Feb 2008.

. The intestinal microbiota in inflammatory bowel diseases. Nestle Nutr Inst Workshop Ser, v. 79, p. 29-39, 2014.

SASAKI, M. et al. The 3-hydroxy-3-methylglutaryl-CoA reductase inhibitor pravastatin reduces disease activity and inflammation in dextran-sulfate induced colitis. J Pharmacol Exp Ther, v. 305, n. 1, p. 78-85, Apr 2003.

SBIERA, S. et al. Influence of short-term glucocorticoid therapy on regulatory T cells in vivo. PLoS One, v. 6, n. 9, p. e24345, 2011.

SCHACKE, H.; DOCKE, W. D.; ASADULLAH, K. Mechanisms involved in the side effects of glucocorticoids. Pharmacol Ther, v. 96, n. 1, p. 23-43, Oct 2002.

SCHLEIMER, R. P.; BOCHNER, B. S. The effects of glucocorticoids on human eosinophils. J Allergy Clin Immunol, v. 94, n. 6 Pt 2, p. 1202-13, Dec 1994.

SCHMIDT, M. et al. Glucocorticoids induce apoptosis in human monocytes: potential role of IL-1 beta. J Immunol, v. 163, n. 6, p. 3484-90, Sep 151999.

SEDDIKI, N. et al. Expression of interleukin (IL)-2 and IL-7 receptors discriminates between human regulatory and activated T cells. J Exp Med, v. 203, n. 7, p. 1693-700, Jul 102006. 
SEPULVEDA, S. E. et al. [Inflammatory bowel diseases: an immunological approach]. Rev Med Chil, v. 136, n. 3, p. 367-75, Mar 2008.

SHAH, Y. M.; MORIMURA, K.; GONZALEZ, F. J. Expression of peroxisome proliferator-activated receptor-gamma in macrophage suppresses experimentally induced colitis. Am J Physiol Gastrointest Liver Physiol, v. 292, n. 2, p. G657-66, Feb 2007.

SIRTORI, C. R. The pharmacology of statins. Pharmacol Res, v. 88, p. 3-11, Oct 2014.

SMYTH, M. J. et al. Activation of NK cell cytotoxicity. Mol Immunol, v. 42, n. 4, p. 501-10, Feb 2005.

SODERHOLM, J. D. et al. Augmented increase in tight junction permeability by luminal stimuli in the non-inflamed ileum of Crohn's disease. Gut, v. 50, n. 3, p. 307-13, Mar 2002.

SOYSETH, V. et al. Statin use is associated with reduced mortality in COPD. Eur Respir J, v. 29, n. 2, p. 279-83, Feb 2007.

SPITS, H.; CUPEDO, T. Innate lymphoid cells: emerging insights in development, lineage relationships, and function. Annu Rev Immunol, v. 30, p. 647-75, 2012.

STANCU, C.; SIMA, A. Statins: mechanism of action and effects. J Cell Mol Med, v. 5, n. 4, p. 37887, Oct-Dec 2001.

STEINMAN, R. M.; NUSSENZWEIG, M. C. Avoiding horror autotoxicus: the importance of dendritic cells in peripheral T cell tolerance. Proc Natl Acad Sci U S A, v. 99, n. 1, p. 351-8, Jan 82002.

STOCK, P. et al. Respiratory tolerance is inhibited by the administration of corticosteroids. J Immunol, v. 175, n. 11, p. 7380-7, Dec 12005.

STOLTE, E. H. et al. Evolution of glucocorticoid receptors with different glucocorticoid sensitivity. J Endocrinol, v. 190, n. 1, p. 17-28, Jul 2006.

STONE, N. J. et al. 2013 ACC/AHA guideline on the treatment of blood cholesterol to reduce atherosclerotic cardiovascular risk in adults: a report of the American College of Cardiology/American Heart Association Task Force on Practice Guidelines. J Am Coll Cardiol, v. 63, n. 25 Pt B, p. 2889934, Jul 12014.

SUZUKI, S. et al. Preventive effect of fluvastatin on ulcerative colitis-associated carcinogenesis in mice. Anticancer Res, v. 26, n. 6B, p. 4223-8, Nov-Dec 2006.

SZKARADKIEWICZ, A. et al. Proinflammatory cytokines and IL-10 in inflammatory bowel disease and colorectal cancer patients. Arch Immunol Ther Exp (Warsz), v. 57, n. 4, p. 291-4, Jul-Aug 2009. 
TAGORE, A. et al. Interleukin-10 (IL-10) genotypes in inflammatory bowel disease. Tissue Antigens, v. 54, n. 4, p. 386-90, Oct 1999.

TAKAHASHI, $\mathrm{T}$. et al. Immunologic self-tolerance maintained by CD25(+)CD4(+) regulatory $\mathrm{T}$ cells constitutively expressing cytotoxic T lymphocyte-associated antigen 4. J Exp Med, v. 192, n. 2, p. 30310, Jul 172000.

TANAKA, T. et al. Lipophilic statins suppress cytotoxicity by freshly isolated natural killer cells through modulation of granule exocytosis. Int Immunol, v. 19, n. 2, p. 163-73, Feb 2007.

TERZIC, J. et al. Inflammation and colon cancer. Gastroenterology, v. 138, n. 6, p. 2101-2114 e5, Jun 2010.

TONELLI, M. et al. Efficacy of statins for primary prevention in people at low cardiovascular risk: a meta-analysis. CMAJ, v. 183, n. 16, p. E1189-202, Nov 82011.

TOROK, H. P. et al. Epistasis between Toll-like receptor-9 polymorphisms and variants in NOD2 and IL23R modulates susceptibility to Crohn's disease. Am J Gastroenterol, v. 104, n. 7, p. 1723-33, Jul 2009.

TREMAINE, W. J. Diagnosis and treatment of indeterminate colitis. Gastroenterol Hepatol (N Y), v. 7, n. 12, p. 826-8, Dec 2011.

TREUTING, P. M.; DINTZIS, S. M. 12 - Lower Gastrointestinal Tract. In: DINTZIS, P. M. T. M. (Ed.). Comparative Anatomy and Histology. San Diego: Academic Press, 2012. p.177-192. ISBN 978-012-381361-9.

TU, H. et al. Dual effects of statins therapy in systemic lupus erythematosus and SLE-related atherosclerosis: the potential role for regulatory T cells. Atherosclerosis, v. 222, n. 1, p. 29-33, May 2012.

TUCKERMANN, J. P. et al. Molecular mechanisms of glucocorticoids in the control of inflammation and lymphocyte apoptosis. Crit Rev Clin Lab Sci, v. 42, n. 1, p. 71-104, 2005.

TUNG, J. et al. A population-based study of the frequency of corticosteroid resistance and dependence in pediatric patients with Crohn's disease and ulcerative colitis. Inflamm Bowel Dis, v. 12, n. 12, p. 1093-100, Dec 2006.

TURLEY, S. J.; FLETCHER, A. L.; ELPEK, K. G. The stromal and haematopoietic antigen-presenting cells that reside in secondary lymphoid organs. Nat Rev Immunol, v. 10, n. 12, p. 813-25, Dec 2010.

VAMVAKOPOULOS, J. E.; GREEN, C. HMG-CoA reductase inhibition aborts functional differentiation and triggers apoptosis in cultured primary human monocytes: a potential mechanism of statin-mediated vasculoprotection. BMC Cardiovasc Disord, v. 3, p. 6, Jul 192003. 
VAN ASSCHE, G. et al. The second European evidence-based Consensus on the diagnosis and management of Crohn's disease: Definitions and diagnosis. J Crohns Colitis, v. 4, n. 1, p. 7-27, Feb 2010.

VAN DER GOES, A. et al. Dexamethasone promotes phagocytosis and bacterial killing by human monocytes/macrophages in vitro. J Leukoc Biol, v. 67, n. 6, p. 801-7, Jun 2000.

VAN MEETEREN, M. E.; MEIJSSEN, M. A.; ZIJLSTRA, F. J. The effect of dexamethasone treatment on murine colitis. Scand J Gastroenterol, v. 35, n. 5, p. 517-21, May 2000.

VAROL, C.; ZIGMOND, E.; JUNG, S. Securing the immune tightrope: mononuclear phagocytes in the intestinal lamina propria. Nat Rev Immunol, v. 10, n. 6, p. 415-26, Jun 2010.

VELDHOEN, M. et al. TGFbeta in the context of an inflammatory cytokine milieu supports de novo differentiation of IL-17-producing T cells. Immunity, v. 24, n. 2, p. 179-89, Feb 2006.

VERDIER, J. et al. Compartmentalized expression of Th1 and Th17 cytokines in pediatric inflammatory bowel diseases. Inflamm Bowel Dis, v. 18, n. 7, p. 1260-6, Jul 2012.

VICTORIA, C. R.; SASSAK, L. Y.; NUNES, H. R. Incidence and prevalence rates of inflammatory bowel diseases, in midwestern of Sao Paulo State, Brazil. Arq Gastroenterol, v. 46, n. 1, p. 20-5, JanMar 2009.

VIGNALI, D. A. A.; COLLISON, L. W.; WORKMAN, C. J. How regulatory T cells work. Nat Rev Immunol, v. 8, n. 7, p. 523-532, 2008.

WALKER, A. W. et al. High-throughput clone library analysis of the mucosa-associated microbiota reveals dysbiosis and differences between inflamed and non-inflamed regions of the intestine in inflammatory bowel disease. BMC Microbiol, v. 11, p. 7, 2011.

WANG, C. Y.; LIU, P. Y.; LIAO, J. K. Pleiotropic effects of statin therapy: molecular mechanisms and clinical results. Trends Mol Med, v. 14, n. 1, p. 37-44, Jan 2008.

WEHKAMP, J. et al. Reduced Paneth cell alpha-defensins in ileal Crohn's disease. Proc Natl Acad Sci U S A, v. 102, n. 50, p. 18129-34, Dec 132005.

WEITZ-SCHMIDT, G. et al. Statins selectively inhibit leukocyte function antigen-1 by binding to a novel regulatory integrin site. Nat Med, v. 7, n. 6, p. 687-92, Jun 2001.

WENKE, K. et al. Simvastatin reduces graft vessel disease and mortality after heart transplantation: a four-year randomized trial. Circulation, v. 96, n. 5, p. 1398-402, Sep 21997. 
WONG, S.; NG, S. What Can We Learn From Inflammatory Bowel Disease in Developing Countries? Current Gastroenterology Reports, v. 15, n. 3, p. 1-9, 2013/02/07 2013.

WOOD, W. G.; MUPSILONLLER, W. E.; ECKERT, G. P. Statins and neuroprotection: basic pharmacology needed. Mol Neurobiol, v. 50, n. 1, p. 214-20, Aug 2014.

WU, X. et al. Selective sequestration of STAT1 in the cytoplasm via phosphorylated SHP-2 ameliorates murine experimental colitis. J Immunol, v. 189, n. 7, p. 3497-507, Oct 12012.

XYSTRAKIS, E. et al. Reversing the defective induction of IL-10-secreting regulatory $\mathrm{T}$ cells in glucocorticoid-resistant asthma patients. J Clin Invest, v. 116, n. 1, p. 146-55, Jan 2006.

YAMAMOTO, M. et al. IL-6 is required for the development of Th1 cell-mediated murine colitis. $\mathbf{J}$ Immunol, v. 164, n. 9, p. 4878-82, May 12000.

YAN, Y. et al. Temporal and spatial analysis of clinical and molecular parameters in dextran sodium sulfate induced colitis. PLoS One, v. 4, n. 6, p. e6073, 2009.

YANO, M. et al. Statins activate peroxisome proliferator-activated receptor gamma through extracellular signal-regulated kinase $1 / 2$ and p38 mitogen-activated protein kinase-dependent cyclooxygenase-2 expression in macrophages. Circ Res, v. 100, n. 10, p. 1442-51, May 252007.

YEN, D. et al. IL-23 is essential for T cell-mediated colitis and promotes inflammation via IL-17 and IL-6. J Clin Invest, v. 116, n. 5, p. 1310-6, May 2006.

YILMAZ, A. et al. Differential effects of statins on relevant functions of human monocyte-derived dendritic cells. J Leukoc Biol, v. 79, n. 3, p. 529-38, Mar 2006.

YOSHIMURA, C. et al. Glucocorticoids induce basophil apoptosis. J Allergy Clin Immunol, v. 108, n. 2, p. 215-20, Aug 2001.

YOUSSEF, S. et al. The HMG-CoA reductase inhibitor, atorvastatin, promotes a Th2 bias and reverses paralysis in central nervous system autoimmune disease. Nature, v. 420, n. 6911, p. 78-84, Nov 72002.

$\mathrm{YU}, \mathrm{Q}$. T. et al. Expression and functional characterization of FOXP3+ CD4+ regulatory T cells in ulcerative colitis. Inflamm Bowel Dis, v. 13, n. 2, p. 191-9, Feb 2007.

ZELVYTE, I. et al. Modulation of inflammatory mediators and PPARgamma and NFkappaB expression by pravastatin in response to lipoproteins in human monocytes in vitro. Pharmacol Res, v. 45, n. 2, p. 147-54, Feb 2002.

ZHANG, Y. et al. Statins, bone metabolism and treatment of bone catabolic diseases. Pharmacol Res, v. 88, p. 53-61, Oct 2014. 
ZHOU, Q.; LIAO, J. K. Pleiotropic effects of statins. - Basic research and clinical perspectives. Circ J, v. 74, n. 5, p. 818-26, May 2010.

ZUCKERMAN, G. R. et al. An objective measure of stool color for differentiating upper from lower gastrointestinal bleeding. Dig Dis Sci, v. 40, n. 8, p. 1614-21, Aug 1995. 
8. ANEXOS 


\title{
8. ANEXOS
}

\subsection{Parecer da comissão de ética em experimentação animal}

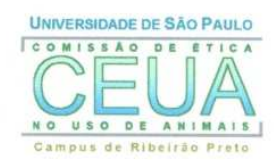

\author{
UNIVERSIDADE DE SÃO PAULO \\ Campus de Ribeirão Preto \\ Comissão de Ética no Uso de Animais
}

C E R T I F I C A D O

Certificamos que o trabalho (Protocolo 13.1.745.53.1), intitulado

"Avaliação dos efeitos imunomoduladores de estatinas e glicocorticoides na terapêutica da colite experimental", de autoria de Paulo José Basso e Cristina Ribeiro de Barros Cardoso, por estar de acordo com os Princípios Éticos na Experimentação Animal adotado pela Comissão de Ética no Uso de Animais (CEUA) do Campus de Ribeirão Preto - USP foi aprovado em reunião da CEUA de 07/10/2013.

This is to certify that the work (Protocol number 13.1.745.53.1), entitled: "Avaliação dos efeitos imunomoduladores de estatinas e glicocorticoides na terapêutica da colite experimental", by Paulo José Basso and Cristina Ribeiro de Barros Cardoso is in accordance with the Ethic Principles in Animal Experimentation adopted by Ethic Commission for the Use of Animals (CEUA) of the Campus of Ribeirão Preto USP, and was approved in an ordinary meeting of CEUA, October, 72013.

Ribeirão Preto, 09 de outubro de 2013.

Presidente da CEUA

Profa. Dra. Cláudia Maria Padovan

HauBgaraia

Secretária da CEUA

Vanessa Bombonato Garcia

Av. Bandeirantes, 3900 - CEP 14040-900 - Ribeirão Preto - São Paulo Fone: (16) 36023526 - Fax: (16) 36023526 